Natália de Lima Figueiredo

\title{
Poder da Marca \\ Interações entre direito antitruste e direito industrial
}

\author{
Dissertação de Mestrado \\ Orientador: Prof. Dr. José Marcelo Martins Proença
}

Universidade de São Paulo

Faculdade de Direito

São Paulo - SP

2014 
Natália de Lima Figueiredo

Poder da Marca

Interações entre direito antitruste e direito industrial

Dissertação apresentada à Banca Examinadora do Programa de Pós-Graduação em Direito, da Faculdade de Direito da Universidade de São Paulo, como exigência parcial para obtenção do título de Mestre em Direito, na área de concentração de Direito Comercial, sob a orientação do Prof. Dr. José Marcelo Martins Proença

Universidade de São Paulo

Faculdade de Direito

São Paulo - SP

2014 


\section{AGRADECIMENTOS}

Agradeço imensamente ao Professor Dr. José Marcelo Proença por ter acreditado no meu trabalho e me orientado em minha trajetória acadêmica. Agradeço também suas excelentes aulas que refletem sua grande dedicação e entrega ao ensino jurídico no país. Agradeço aos Professores Dr. Marcos Veríssimo e Dr. Roberto Pfeiffer pela análise detida do projeto de Mestrado e pelos excelentes comentários que fizeram durante o exame de qualificação que tanto contribuíram para o aprimoramento desta dissertação.

Agradeço a Gabriel Dias por ser grande incentivador da atividade acadêmica e por compartilhar sua visão sobre aspectos importantíssimos do tema deste trabalho.

Agradeço a Lucia pelo direcionamento do tema relacionado aos aspectos consumeristas que enriqueceram muito o resultado da dissertação.

Agradeço a Francisco Negrão pela motivação que me inspirou na realização do trabalho.

Agradeço ao Cristiano Del Debbio por toda a ajuda, todo debate e todo o incentivo na realização deste trabalho. Sua experiência e pensamento critico foram fundamentais para o aprofundamento de questões relevantes.

Agradeço a Thaís Guerra, Hermes Nereu Oliveira, Déborah Melo e Leonardo Barbosa pelo apoio constante.

Agradeço a meus pais, Regina e Hugo, a meu irmão, Victor, a meu namorado, Carlos, e aos amigos, Paulo, Raquel, Ana e Carol, pelo amor e apoio incondicionais. 


\section{RESUMO}

Natália de Lima Figueiredo. Poder da Marca: interações entre direito antitruste e direito industrial. 2014. 206 páginas. Mestrado - Faculdade de Direito, Universidade de São Paulo, São Paulo, 2014.

O presente trabalho busca analisar os diferentes tratamentos dispensados à marca no âmbito do controle preventivo e no controle repressivo de condutas. A análise da função social das marcas demonstrou que esta é uma propriedade que se realiza na concorrência e pela concorrência. Nesse sentido, não há dúvidas de que está sujeita aos princípios do Direito Concorrencial. Todavia, a maneira como esses princípios balizam a marca no controle de atos de concentração, de um lado, e no controle repressivo de condutas, de outro, difere. No âmbito do controle de atos de concentração, a atuação da autoridade concorrencial é orientada por uma variante do princípio da precaução, o que a autoriza a tomar decisões e impor restrições aos direitos marcários mesmo em um contexto de incerteza. No âmbito do controle repressivo de condutas, todavia, a intervenção do CADE está sujeita aos princípios do Processo Administrativo Sancionador. Neste contexto, as condutas que envolvem o uso de direitos de propriedade intelectual, incluindo as marcas, devem ser analisadas à luz do princípio da estrita legalidade. Um critério jurídico objetivo é necessário para distinguir o lícito do ilícito, sobretudo em um cenário no qual estão em jogo duas políticas públicas distintas: a de proteção à concorrência e a de proteção à direitos de propriedade industrial. Sendo essas duas políticas instrumentais e parciais, voltadas a um fim maior de política econômica, devem harmonizar-se, e não sobrepor-se uma a outra. Ademais, o escopo de atuação da autoridade concorrencial em processos que investiguem o uso abusivo de direitos marcários e atos de concorrência desleal deve ser esclarecido. $\mathrm{O}$ direito concorrencial, enquanto ramo autônomo do direito, com princípios e métodos interpretativos próprios, pode analisar institutos e figuras de outros ramos que com ele guardem relação sem ter de ficar adstrito ao posicionamento de outras instâncias.

Palavras-chave: Direito concorrencial, marcas, controle preventivo e repressivo de condutas, limites de atuação. 


\begin{abstract}
Natália de Lima Figueiredo. Power of Trademarks: interactions between antitrust and industrial property law. 2014. 206 pages. Master - Faculty of Law, University of São Paulo, Sao Paulo, 2014.
\end{abstract}

This work has the purposes of analyzing the different treatments trademarks are subject in the fields of merger control and antitrust infringement proceedings. The analysis of the social function of trademark showed that it is a property that becomes effective in and by means of competition. In this sense, there is no doubt that it is subject to the principles of Antitrust Law. However, the way these principles limits trademark rights in the context of merger control, on one side, and, antitrust infringement proceedings, on the other, varies. In the field of merger control, the antitrust authority is guided by a variant of the precautionary principle, which empowers it to make decisions and impose restrictions to trademark rights even in a context of uncertainty. However, under antitrust infringement proceedings, CADE's intervention is subject to the principles of the Sanctioning Administrative Procedure. As a result, the conducts that involve intellectual property rights, including trademark rights, must be analyzed in view of the principle of strict legality. An objective legal criterion is necessary to distinguish licit from illicit behaviors especially under a scenario where two different public policies are at stake: the one relating to competition defense and the other concerning the protection to intellectual property rights. Since these two policies are instrumental, partial and targeted to a higher objective connected with economic policy, they should be harmonized and not overlap each other. In addition, the scope of the competition authority's jurisdiction in antitrust infringement proceedings which investigate the abuse of trademark laws and acts of unfair competition should be clarified. Antitrust law, as an independent legal field, which contains its own principles and interpretation methods, can analyze institutes from other legal fields to which it is related without being bound by the positioning of other instances.

Key-words: Competition law, trademark, merger control, antitrust infringement proceedings, scope of jurisdiction. 


\section{SUMÁRIO}

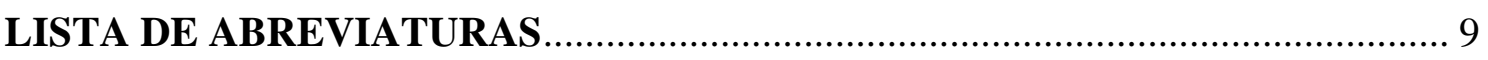

INTRODUÇÃ

CAPÍTULO 1. MARCAS - CONCEITO, EVOLUÇÃO, FUNÇÕES E JUSTIFICATIVAS PARA PROTEÇÃO LEGAL ................................................ 13

1.1. Considerações iniciais: conceito e evolução do instituto das marcas .............. 13

1.2. Função das marcas no processo competitivo ................................................. 16

1.2.1. Marca enquanto indicador de origem e qualidade ..................................... 16

1.2.2. Marca enquanto criadora de mercado e direcionadora da demanda ............. 18

1.2.3. Marca enquanto barreira à entrada ............................................................ 20

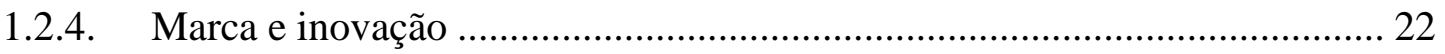

1.3. Justificativas para proteção legal à marca..................................................... 24

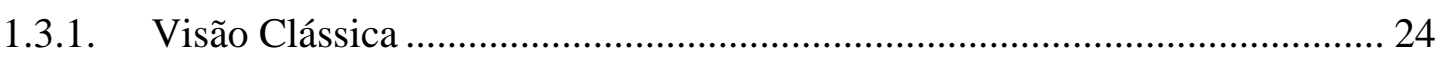

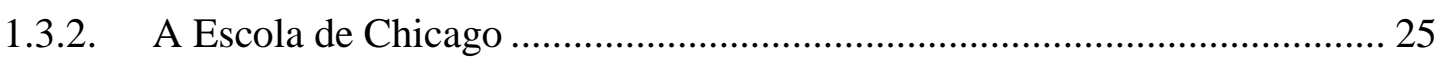

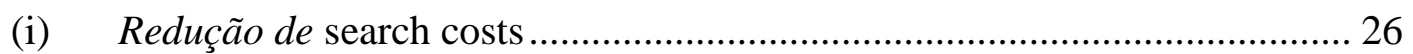

(ii) Investimentos em publicidade é sinônimo de qualidade .............................. 27

(iii) Proteção contra free riders $e$ construção da reputação da empresa ............ 28

(iv) Preço supracompetitivo do produto com marca é justificado por benefícios

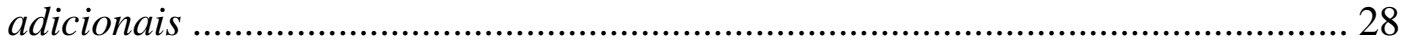

1.3.3. Críticas à proteção ampla às marcas: o Estruturalismo de Harvard .............. 29

(i) Marca não necessariamente pressupõe qualidade .................................... 29

(ii) Marca como mecanismo de preservação de poder de mercado: barreiras à entrada como pressuposto fundamental ................................................................ 31

(iii) O Caso ReaLemon: precedente ilustrativo do pensamento da Escola

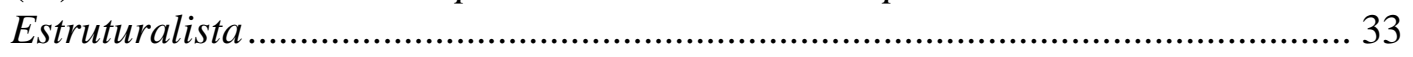

1.3.4. Conclusões sobre as justificativas de proteção legal às marcas ................... 36

CAPÍTULO 2. MARCAS - NOÇÕES DE PROPRIEDADE E SEUS

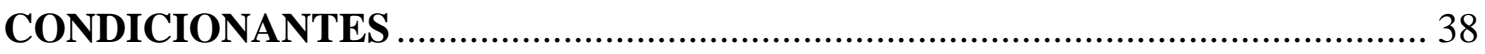

2.1. Marca como propriedade e seus condicionantes........................................... 38

2.2. Limites concorrenciais ao exercício do direito marcário ................................ 40

2.2.1. Princípios da livre concorrência e da repressão ao abuso de poder econômico como elementos balizadores do direito de propriedade intelectual ........................... 40

2.2.2. Interpretação equilibrada entre direito da concorrência e os direitos

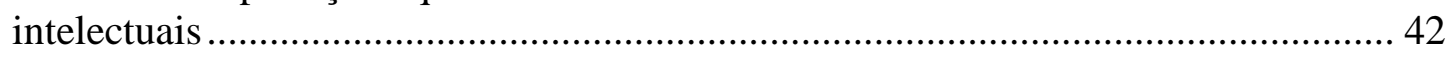

2.3. Proteção ao consumidor como condicionante ao uso da marca....................... 46

2.4. Limites inerentes à função social da propriedade ........................................... 50

2.4.1. Noções gerais sobre a função social da propriedade.................................... 50 
2.4.2. Função social da propriedade industrial: histórico.

2.4.3. Função social da propriedade industrial: a questão específica da marca ..... 56

2.4.4. Legislação marcária: regras que dão concretude à função concorrencial das

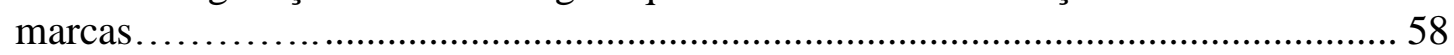

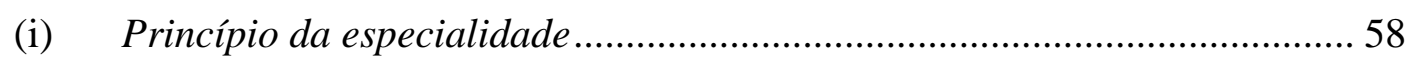

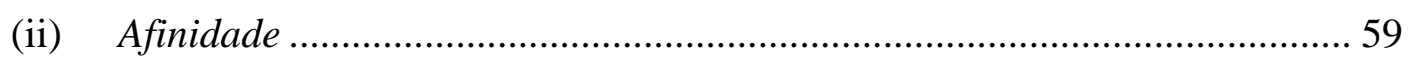

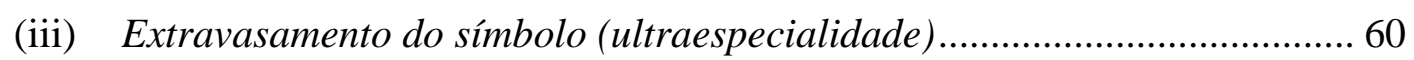

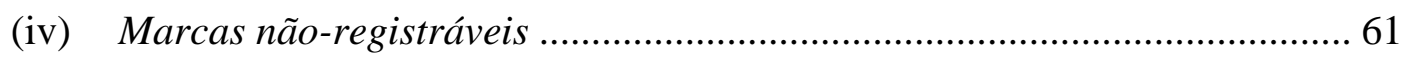

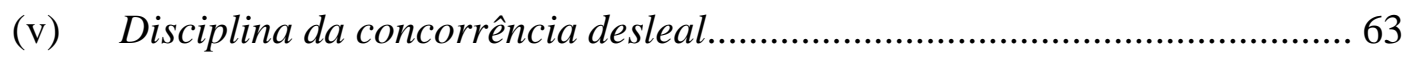

2.5. Questões práticas derivadas da incidência de múltiplos condicionantes: interações entre as diversas esferas e potenciais conflitos decisórios ........................ 65

CAPÍTULO 3. MARCAS E O CONTROLE DE ESTRUTURAS ........................... 73

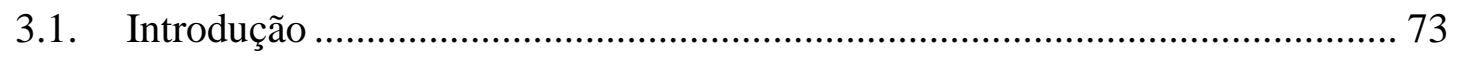

3.2. Da necessidade de notificação de contratos de licenciamento.......................... 75

3.2.1. Contratos de licenciamento de PI como contratos associativos: os casos

Monsanto e a nova regulamentação do CADE.......................................................... 76

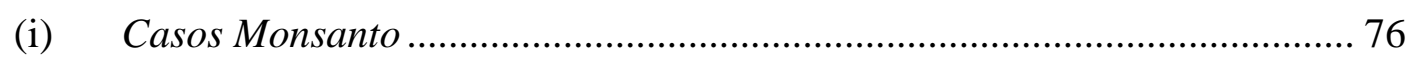

(ii) Nova regulamentação do CADE sobre contratos associativos: Resolução $n^{o}$.

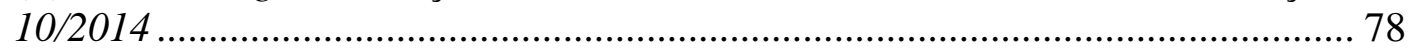

3.2.2. Notificação de contratos de licenciamento de marca ................................. 81

3.3. Definição de mercado de produtos diferenciados ........................................ 82

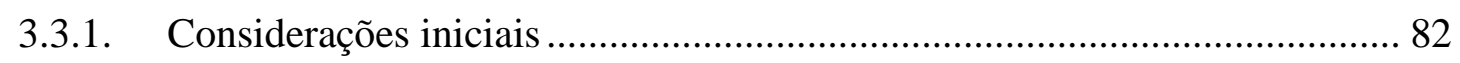

3.3.2. Análise da concorrência entre produtos diferenciados................................ 85

3.3.3. Definição de produtos diferenciados: conceito de submercado .................... 88

3.3.4. Flexibilização da definição de mercado .................................................... 93

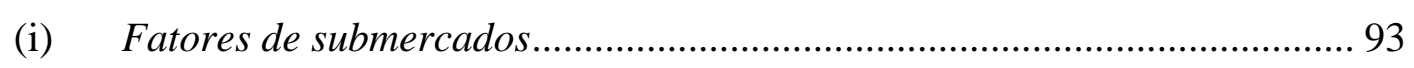

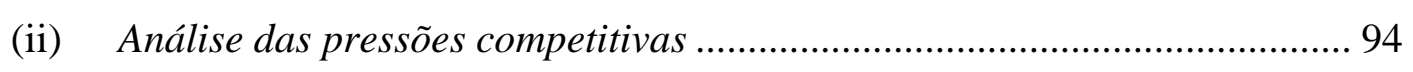

3.3.5. Análise de produtos diferenciados pelo CADE........................................... 96

3.4. Análise das marcas no exame de probabilidade de exercício de poder de

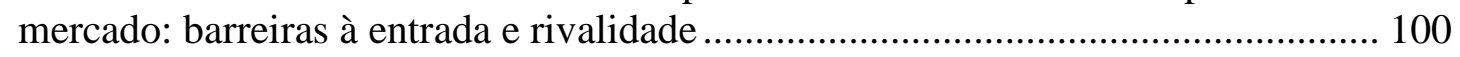

3.4.1. Aspectos teóricos sobre barreiras à entrada ............................................. 100

3.4.2. Barreiras à entrada baseadas na diferenciação de produto: marca e

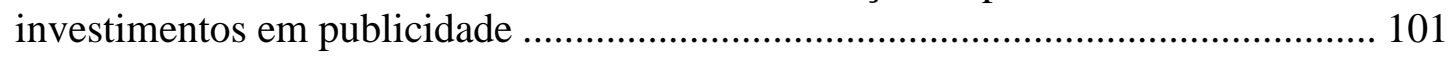

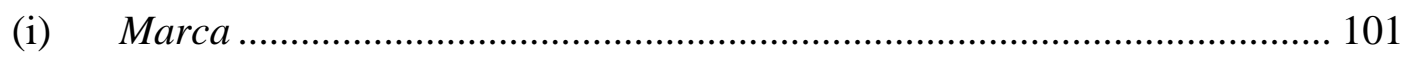

(ii) Investimentos em publicidade ............................................................... 102

3.4.3. Marca na análise de rivalidade entre empresas ........................................ 104

3.5. Remédios antitruste envolvendo direitos sobre marca ................................ 106

3.5.1. Considerações iniciais sobre remédios antitruste..................................... 106 
3.5.2. Remédios concorrenciais aplicáveis às marcas

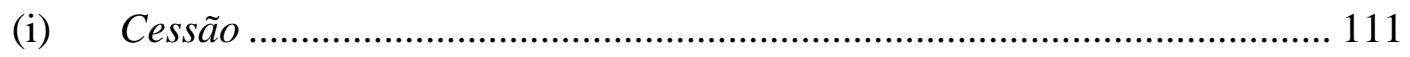

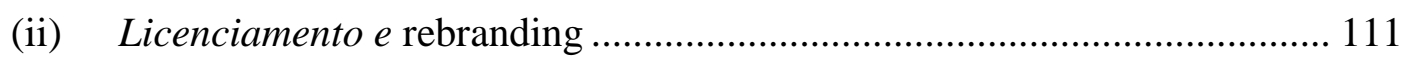

(iii) Suspensão do uso da marca por determinado período .............................. 113

3.5.3. Análise da efetividade de remédios envolvendo limitações ao direito de marca: estudo de casos ................................................................................... 113

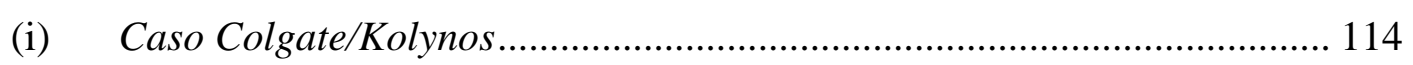

(ii) Caso Sadia/Perdigão......................................................................... 118

(iii) Constituição da Ambev......................................................................... 119

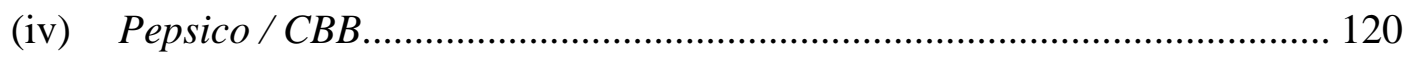

(v) Conclusões sobre restrições envolvendo direitos sobre marca .................. 120

CAPÍTULO 4. MARCAS E O CONTROLE DE CONDUTAS ............................ 122

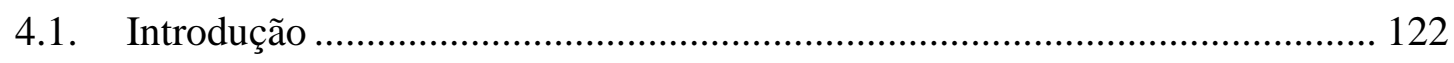

4.2. Estrutura do ilícito antitruste: ato, pressupostos, elemento volitivo e efeitos 123

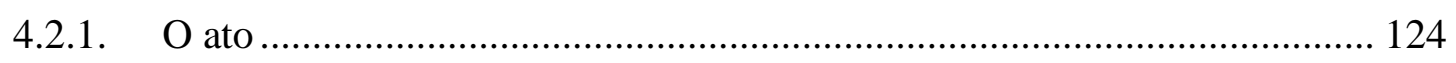

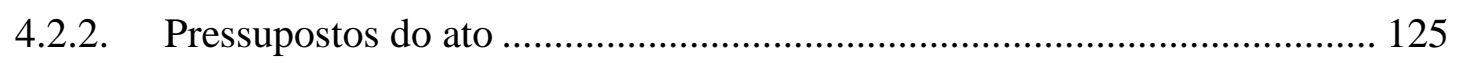

(i) Limitação, falseamento ou qualquer forma de prejuízo à livre concorrência ou à livre iniciativa.

(ii) Dominação do mercado relevante de bens ou serviços e abuso de posição dominante .....

(iii) Aumento arbitrário dos lucros .............................................................. 128

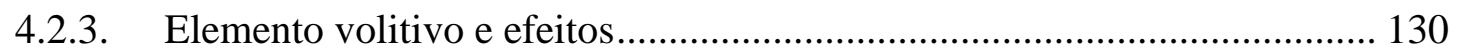

4.3. Condutas anticoncorrenciais envolvendo o uso de direitos de propriedade

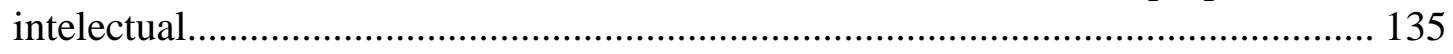

4.3.1. Uma proposta de análise de (i)licitude ................................................. 135

4.3.2. Análise de ilicitude conduzida pelas autoridades antitrustes em casos

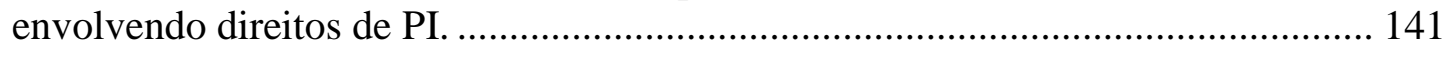

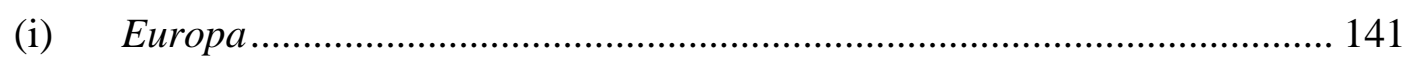

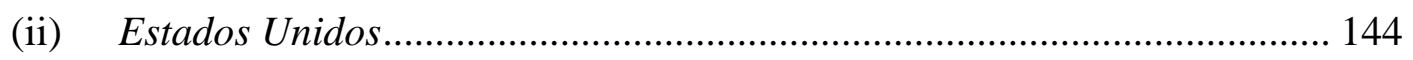

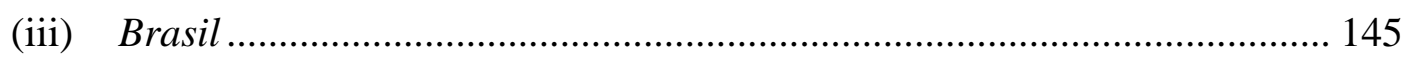

4.4. Abuso do direito de marca sob a perspectiva do direito concorrencial ......... 149

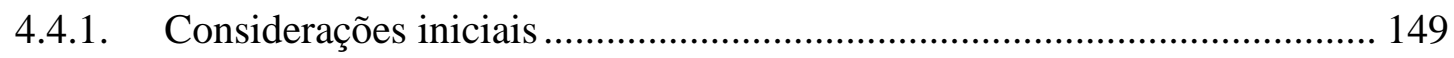

4.4.2. Abuso de posição dominante e marca ...................................................... 149

(i) Atos de concorrência desleal .................................................................. 151

(ii) Abusos e fraudes em procedimentos de registro de marca ........................ 156

(iii) Práticas discriminatórias envolvendo o uso de marcas de certificação.... 162

(iv) Questões ligadas ao licenciamento de marcas ......................................... 164

(v) Predação via diferenciação por marcas .................................................. 167 
4.5. Publicidade e marketing: interações com Direito da Concorrência.

4.5.1. Considerações iniciais

4.5.2. Publicidade enganosa, denigritória e confusória como infração concorrencial 176

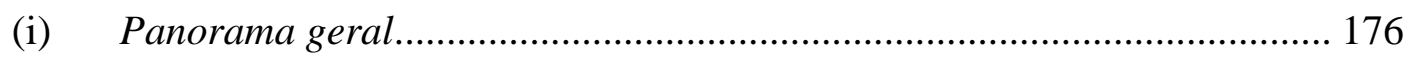

(ii) Requisitos do ilícito: uma análise de jurisprudência nacional e

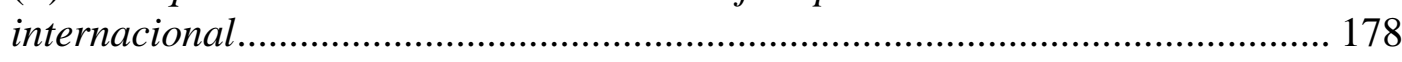

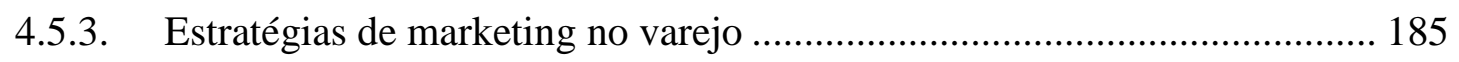

(i) Espaço em prateleira ............................................................................ 185

(ii) Gerenciamento de categoria e a figura do capitão de categoria .............. 186

(iii) Exclusividade de merchandising .............................................................. 190

(iv) Gueltas e os incentivos econômicos informais a vendedores .................... 191

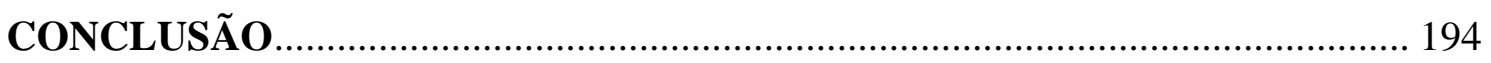

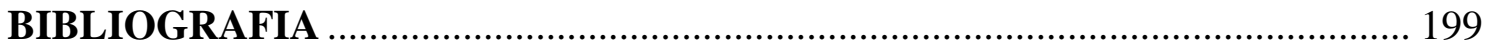

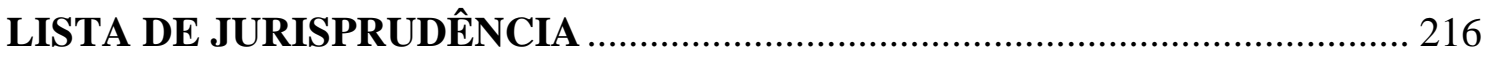




\section{LISTA DE ABREVIATURAS}

CADE

$\mathrm{CC}$

CDC

$\mathrm{CF}$

$\mathrm{CP}$

ECJ

FNE

FTC

INPI

LPI

OCDE

PI

ProCADE

PROCON

SG

STF

STJ

TADE

TDLC

TRF
Conselho Administrativo de Defesa Econômica

Código Civil - Lei nº 10.406/2002

Código de Defesa do Consumidor - Lei nº . 8.078/1990

Constituição Federal

Código Penal - Decreto-lei n ${ }^{\circ}$. 2.848/1940

European Court of Justice (União Europeia)

Fiscalía Nacional Económica (Chile)

Federal Trade Commission (EUA)

Instituto Nacional da Propriedade Industrial

Lei da Propriedade Industrial - Lei no . 9.279/1996

Organização para a Cooperação e Desenvolvimento Econômico

Propriedade intelectual

Procuradoria Federal Especializada junto ao Conselho Administrativo de Defesa Econômica

Fundação de Proteção e Defesa do Consumidor

Superintendência-Geral do Conselho Administrativo de Defesa Econômica

Supremo Tribunal Federal

Superior Tribunal de Justiça

Tribunal Administrativo de Defesa Econômica

Tribunal de Defensa de la Libre Competencia (Chile)

Tribunal Regional Federal 



\section{INTRODUÇÃO}

Ao longo das últimas duas décadas, houve uma profusão de trabalhos sobre a intersecção entre o Direito Antitruste e o Direito da Propriedade Industrial. A maioria deles, no entanto, teve como ponto central de análise a questão das patentes. As marcas, embora atualmente representem um dos principais ativos empresariais e, em termos quantitativos, tenham maior circulação no comércio do que as patentes, ${ }^{1}$ receberam pouca atenção da doutrina especializada.

Ademais, em que pese haver, atualmente, uma percepção de que as empresas tendem a, cada vez mais, utilizar as marcas como uma barreira estratégica à entrada de concorrentes (OCDE/INNO-TEC, 2009), são poucos os casos de condutas envolvendo direitos marcários que efetivamente chegam à análise das autoridades antitruste. Por outro lado, as marcas sempre estiveram presentes de forma bastante relevante na análise de atos de concentração.

No âmbito do CADE, até algum tempo atrás, havia o entendimento de que violações a direitos de marca, incluindo atos de concorrência desleal, eram alheios à competência desta autoridade e refugiam inteiramente aos objetivos da Lei Antitruste. ${ }^{2}$ Ao mesmo tempo, a autoridade concorrencial sentia-se à vontade para ordenar a suspensão do uso e a alienação de marcas no contexto de atos de concentração. ${ }^{3}$

Mesmo nas poucas decisões julgadas recentemente pelo CADE sobre o tema de abuso de marca e concorrência desleal, muito embora já haja clareza no sentido de que tais atos podem implicar violações à lei antitruste, ainda está pouco claro qual o critério mais adequado para analisar casos que envolvam direitos de propriedade industrial, incluindo-se, naturalmente, as marcas.

Além disso, há certa nebulosidade quanto à competência da autoridade antitruste para analisar questões específicas, ${ }^{4}$ uma vez que se trata de uma matéria que é comum a diversos ramos do Direito e pode ser analisada por instâncias decisórias

\footnotetext{
${ }^{1}$ De acordo com as estatísticas do INPI, em 2012, foram depositadas 150.107 pedidos de registro de marcas e apenas 33.395 pedidos de patentes. No mesmo ano, foram registradas 55.306 marcas e apenas foram concedidas 3.130 patentes (BRASIL, 2013c).

${ }^{2}$ Nesse sentido, Bombril v. Lamisa (BRASIL, 1983); Santa Branca v. Terra Branca (BRASIL, 1987a); Vinhos e Bebidas Caldas / Bebidas Cinzano (BRASIL, 1987b).

${ }^{3}$ Vide, por exemplo, Colgate / Kolynos (BRASIL, 1996a) e o caso referente à constituição da Ambev (BRASIL, 2000a).

${ }^{4}$ Vide, a título ilustrativo, o parecer da Superintendência-Geral do CADE no caso Vigor v. Kellog e Danone (BRASIL, 2013e).
} 
distintas. Mais especificamente, questões marcárias podem ter implicações não só no Direito de Propriedade Intelectual, mas também no Direito do Consumidor, no Direito Antitruste e no Direito Penal, e ser analisadas no âmbito cível (jurisdição cível), penal (jurisdição penal) e administrativo (INPI, CADE, PROCON). Neste contexto, podem surgir dúvidas quanto aos limites da atuação da autoridade concorrencial.

Diante dessas questões, o presente trabalho busca fazer um estudo aprofundado das marcas no contexto do Direito Antitruste a fim de melhor compreender (a) essa aparente dicotomia no tratamento das marcas no campo do controle preventivo (atos de concentração), de um lado, e no campo do controle repressivo, de outro; e, ainda, (b) o escopo de atuação da autoridade antitruste na análise de condutas envolvendo, de modo geral, os direitos de propriedade intelectual, e, mais especificamente, as marcas.

Para tanto, no Capítulo 1, faz-se uma revisão teórica do instituto marcário, indicando sua origem, evolução conceitual e prática, funções, justificativas para sua proteção legal e o tratamento conferido pelas principais escolas de pensamento antitruste, a Escola de Chicago e a Escola Estruturalista de Harvard.

No Capítulo 2, analisa-se a marca enquanto propriedade constitucionalmente limitada por princípios relacionados à livre concorrência, à repressão ao abuso de poder econômico, à proteção do consumidor e à própria função social da propriedade. Ademais, faz-se um exame da Lei $n^{\circ}$. 9.279/1996 na busca por regras e princípios que deem concretude e ajudem a melhor compreender a função social da marca. Considerando a amplitude de regras pertencentes a diversos ramos do Direito que condicionam o uso da marca, examina-se como se dá a interação entre essas diversas áreas no processo decisório. Aqui, trata-se especificamente da questão da competência das diversas instâncias decisórias - sobretudo do CADE - na análise de questões marcárias e expõem-se potenciais conflitos entre elas.

No Capítulo 3, objetiva-se tratar, de forma ampla, a questão da marca no contexto de atos de concentração, discutindo-se desde a necessidade de notificação de contratos de licenciamento, passando pelo impacto das marcas na definição do mercado relevante e no exame de poder de mercado, até chegar à análise dos remédios em atos de concentração que envolvam amplo transacionamento de direitos marcários. Com relação a este último ponto, se buscará perquirir as razões por detrás dos poderes amplos outorgados à autoridade concorrencial no campo do controle preventivo de condutas. 
O Capítulo 4, por fim, é destinado ao estudo dos critérios para análise concorrencial de condutas que envolvam direitos de propriedade industrial, de maneira ampla, e, especificamente, aquelas que se utilizem das marcas como instrumento para práticas abusivas do ponto de vista do Direito Concorrencial. Para tanto, será analisada a doutrina especializada sobre a matéria e a jurisprudência nacional e internacional. Ademais, por uma questão de completude do tema relativo à intersecção entre concorrência e marcas, são estudadas aquelas condutas que, embora não envolvam um uso abusivo da marca em si, visam prejudicar a marca de concorrentes e, por essa razão, podem ter potencial anticompetitivo. Fala-se aqui das condutas que envolvam o uso abusivo da publicidade e das estratégias de marketing.

Com isso, objetiva-se chegar a respostas para os diferentes tratamentos da marca no âmbito do controle preventivo e do controle repressivo de condutas, bem como para o escopo e os limites da atuação da autoridade concorrencial. 


\section{CAPÍTULO 1. MARCAS - CONCEITO, EVOLUÇÃO, FUNÇÕES E JUSTIFICATIVAS PARA PROTEÇÃO LEGAL}

\subsection{Considerações iniciais: conceito e evolução do instituto das marcas}

A palavra brand, que significa "marca" em inglês, tem origem no termo escandinavo brandr, cujo significado é queimar. Cabeças e peças de gado eram marcadas com o propósito de identificação das rezes pelos proprietários e possuidores. Com isso, aqueles criadores mais conhecidos pela qualidade do seu gado tinham suas marcas mais procuradas nas trocas comerciais.

A utilização de signos para marcar algo com o propósito de caracterizar pertencimento ou para sinalizar identidade é prática antiquíssima. A utilização de símbolos acompanham os registros da atividade humana. Podiam ter a função de assinalar a propriedade de um bem (e.g. gado ou escravos). Em determinadas comunidades, por sua vez, membros marcavam-se com tatuagens, o que podia ter um caráter religioso, representar ritos sociais ou ostentação de poder. Vestuários e adornos específicos em ambientes sacerdotais refletiam questões místicas ao mesmo tempo em que representavam uma “estruturação de papéis sociais” (PEROTTO, 2007, p. 21).

No comércio, a utilização de símbolos para indicar a procedência de determinado bem também era comum desde a Antiguidade. No Egito, por exemplo, os oleiros colocavam símbolos em seus tijolos para identificar suas mercadorias. Na Roma antiga, também era comum gravar sinais no produto a fim de identificar o artesão que o fabricou e, ainda, evitar roubos de mercadorias. Símbolos de procedência também foram observados em ânforas de vinho e óleo no Mediterrâneo e em países nórdicos. Conforme apontado por Perotto (2007, p. 22-23), "com esse uso de símbolos apareceram, também, os primeiros casos de falsificação de produtos que poderiam resultar, no caso do direito romano, em ações civis de actio injuria ou actio doli”.

Durante o Feudalismo, havia utilização obrigatória de símbolos em determinados produtos pelas corporações de ofício, as quais detinham o monopólio na sua comercializaçao. Cada corporação detinha uma marca específica. De acordo com Silveira (2011, p. 104), “(...) as marcas corporativas constituiam uma ferramenta para 
controlar a concorrência, dentro de um sistema de concorrência limitada, cujos preços eram uniformes e pré-fixados" e, ainda, tinham "função de garantia de qualidade".

Durante o Mercantilismo, por sua vez, a marca tinha um caráter de "garantia estatal do produto", isto é, de que "processos regulares de certificação eram seguidos" (SALOMÃO FILHO, 2007, p. 129).

Em nenhum desses períodos, todavia, a marca tinha a conotação que tem hoje. A sua concepção atual teve origem apenas no século XIX, com o advento da Revolução Industrial. A marca moderna é "industrial e fortemente ancorada no universo da produção e dos produtos" (SEMPRINI, 2010).

De fato, com o fim do Antigo Regime, a função econômica do sistema do direito industrial sofre uma revisão profunda decorrente de princípios, transformadores da organização do trabalho e da produção, introduzidos pela Revolução Industrial. A nova ordem é marcada pela quebra dos corpos econômicos e políticos intermediários com vistas ao fortalecimento do Estado. A liberdade de profissão e de concorrência ganha importância, o que produz fortes mudanças no fundamento econômico e também na disciplina legal das marcas e patentes (SALOMÃO FILHO, 2007).

Dessa forma, a marca tal como conhecida hoje só faz sentido no contexto de uma sociedade de mercado, liberdade de indústria e comércio (SILVEIRA, 2011). Em sua evolução, a marca acompanha as práticas de consumo, servindo de vitrine para os novos produtos industrializados, em substituição ao produto agrário e o artesanal, invadindo o varejo. Encontra, em geral, grande aceitação social no contexto do consumo de massa e do consenso sobre os lemas da modernidade e progresso (SEMPRINI, 2010).

Em especial, foi a partir dos anos de 1920 e 1930 que a marca começou a ser utilizada como uma estratégia institucionalizada de competição entre as empresas. ${ }^{5}$ Nesse esteio, a experiência da General Motors (GM) retratou de maneira inovadora e embrionária o tratamento que passaria a ser dado às marcas pelas empresas em geral.

Diferentemente de sua concorrente, a Ford, que, inicialmente, criou um único modelo de carro dentro da perspectiva "one size fits all", a GM apostou na diferenciação da sociedade como um elemento capaz de criar uma maior aproximação

\footnotetext{
${ }^{5}$ Embora o fenômeno das marcas tenha sido bastante intensificado com a revolução industrial, até o início do século $\mathrm{XX}$ as empresas parecem não ter tido ainda descoberto todas as suas potencialidades (NORBERTO, 2004).
} 
entre o consumidor e os produtos de uma empresa. Dessa maneira, apostou nas marcas e avançou de uma concepção fordista, totalmente submetida à racionalidade dos processos da produção material, isto é, de uma noção de produto eminentemente utilitária, para uma concepção que busca superar a "comoditização" do produto para elevá-lo a uma categoria especial.

A marca serviria, então, para distinguir produtos de acordo com a identificação, distinção e demarcação de indivíduos e de grupos sociais. Com isso, as empresas poderiam atingir seu público-alvo de maneira muito mais efetiva, criando vínculos emocionais com o seu consumidor final.

Se, antes do século XX, o principal segredo para o sucesso de uma firma era fazer um produto com boa qualidade, a partir dos anos 20 e 30, no caso da indústria automobilística, mas sobretudo em meados do século $\mathrm{XX}$, para outras indústrias, os produtos começaram a ter qualidades muito semelhantes. Em outras palavras, havia uma relativa "estandardização" ou padronização da qualidade dos produtos, e, com isso, as empresas procuraram formas mais efetivas de se diferenciarem (ARONS, 2011).

Desse modo, em 1950, companhias como a Procter and Gamble, General Foods e Unilever desenvolveram uma disciplina de brand management - ou marketing como é atualmente conhecida -, quando perceberam o aumento dos níveis de qualidade dos produtos oferecidos por concorrentes. O gerente de marcas passou a ser responsável por dar ao produto uma identidade que o diferenciasse de concorrentes quase indistinguíveis. Isto exigiu maior conhecimento e entendimento do consumidor específico e da marca que deveria oferecer não só um valor funcional, mas também emocional. Com o passar do tempo, o valor emocional criaria um amortecedor contra a paridade funcional. Desde que a marca fosse percebida como superior à de seus concorrentes, a companhia que a oferecesse poderia cobrar mais por seus produtos (ARONS, 2011).

Com isso, estava sedimentada a ideia da marca como estratégia corporativa de diferenciação do produto e de fidelização do consumidor. Este papel é ainda mais fortalecido a partir dos anos 80, caracterizado pelo crescimento econômico e relevante desenvolvimento da comunicação publicitária com substanciais investimentos nesse campo por parte das empresas. Inicia-se o movimento de quebra do monopólio público do audiovisual e de aumento da oferta da comunicação televisiva e de rádio. 
As marcas começam a ultrapassar as limitadas fronteiras do consumo para invadir o espaço social. Crescem não só no universo dos produtos, mas também no dos serviços, e passam a propor um projeto de sentido (semiótica), o qual busca estabelecer uma relação de cumplicidade com o consumidor. Assim, nas palavras de Semprini (2010, p. 32) ${ }^{6}$, "tornam-se fortes indicadores, formas de agregação coletiva e de identidade", e, por conseguinte, um instrumento poderosíssimo no contexto social.

\subsection{Função das marcas no processo competitivo}

\subsubsection{Marca enquanto indicador de origem e qualidade}

Uma das funções mais intuitivas das marcas é a identificação de origem. Como se trata de um símbolo, sua qualidade identificadora é inerente à sua natureza. Trata-se, em outras palavras, de reconhecer de onde provém o produto ou serviço ou, ainda, quem é seu fabricante ou provedor.

Numa sociedade marcada por contratos de rede, a função de identificação da origem da marca, no entanto, deve ser analisada de uma maneira ampla. A marca certamente relaciona-se a determinada empresa. Muitas delas inclusive registram marcas que refletem o nome empresarial. No entanto, dadas as constantes mudanças nos controles acionários das sociedades e grupos econômicos e, ainda, a mobilidade dos processos produtivos, a noção de origem da marca não traz uma correlação necessária com determinada pessoa jurídica, indicação geográfica ou estabelecimento fabril.

Não se está mais diante do comércio do início do século XIX em que os negócios eram, em geral, caracterizados pela pessoalidade, de forma que a marca designaria, primordialmente, o fabricante ou o comerciante de determinado produto.

\footnotetext{
${ }^{6}$ Esse fortalecimento extremo da marca e sua onipresença no espaço social é objeto de análise por Semprini, que afirma que a fase contemporânea desse instituto é caracterizada por dúvida e desconfiança (crise de legitimidade). Segundo Semprini (2010, p. 35-37), "as marcas eram consideradas o vetor do hedonismo, da livre escolha, o indicador do bem-estar econômico e do conforto da vida. (...) Hoje, as marcas continuam a se desenvolver sob o ponto de vista quantitativo, a estender a sua influência em territórios sempre mais vastos e diversificados, mas esse movimento se faz em um contexto cultural muito mais polêmico. $\mathrm{O}$ consenso sobre o benefício das marcas está no mínimo enfraquecido. (...) A demanda de qualidade cresceu em uma velocidade que as grandes marcas nem sempre conseguem acompanhar. As marcas aventuram-se por territórios que têm dificuldade para dominar, assim como o controle de sua produção industrial (...)".
} 
Como consequência, a ideia de origem deve ser reformulada. Nessa perspectiva, a doutrina de Barbosa (2008) esclarece que a origem de que se fala não é a geográfica, a subjetiva ou aquela vinculada ao estabelecimento fabril. ${ }^{7}$

Na mesma linha, Ascensão (2002, p. 21) afirma que “(...) a marca deixou de dizer seja o que for sobre a origem do produto. Por isso sob a mesma marca circulam produtos bons e produtos maus". Ademais, segundo o autor, "há que se distinguir função de determinação de origem e função distintiva. Esgotada a função de determinação de origem, só resta a função distintiva".

De fato, a ideia de origem está muito mais ligada à identificação do produto em si (produto pelo produto) do que à identificação da pessoa que o produziu ou local de produção. Apesar disso, não se pode deixar de reconhecer que os indivíduos, em geral, ligam uma marca forte ao nome de sua empresa, ainda que sejam distintos. ${ }^{8}$ Nesses casos, a marca identifica não só o produto em si, mas claramente revela uma associação entre o produto e seu fabricante. Afinal, a marca também carrega consigo informações relevantes sobre a reputação de uma empresa.

A função identificadora ou distintiva é também importante na construção de um padrão de qualidade do produto. Os consumidores apenas repetem a compra de determinada marca porque têm a expectativa de que se repetirá também a sua experiência inicial de consumo, isto é, espera-se que o produto tenha as mesmas características e as mesmas qualidades que se experimentou na primeira vez em que o bem ou serviço foi consumido. Se isso não ocorrer, a função identificadora da marca perde seu sentido assim como a própria utilização desse símbolo.

Ao discorrer sobre a diferenciação do produto, propaganda e o papel da marca em seu voto em Colgate/Kolynos, a então Conselheira do CADE, Lúcia Helena Salgado, destacou o papel dos bens de experiência, "para os quais as compras repetidas

\footnotetext{
${ }^{7}$ Explicita Barbosa (2008, p. 23) que "(...) há que se distinguir de que origem se fala. Certamente não é a origem geográfica; indicações de procedência e designações de origem vinculam o bem ou serviço a uma origem geográfica, enquanto a marca funciona, muitas vezes, em sentido oposto, por exemplo, como índice de que a coerência e consistência dos produtos ou serviços independem de fatores naturais, como tão veementemente se expressa na indústria vinícola. A origem não é, igualmente, subjetiva. A escolha de produtos e serviços se faz essencialmente pela marca, e não pelo titular ou fabricante. A extrema mobilidade atual no controle e na forma das pessoas jurídicas titulares das marcas, ou fabricantes dos respectivos produtos, torna esse índice irrelevante. A origem também não deve ser entendida como a do estabelecimento fabril ou prestador de serviços. Pelo menos no Brasil, e em quase todos os países em que não se vincula a marca a um estabelecimento, como visto, o signo é licitamente usado, licenciado, vendido, quer os produtos sejam fabricados ou os serviços prestados pelo titular, pelo licenciado, ou por quaisquer terceiros".

${ }^{8}$ A título ilustrativo, cite-se o i-phone, marca pertencente à Apple.
} 
oferecem aos consumidores algum controle sobre a qualidade de tais bens e por isso, incentivo para a empresa sustentar a qualidade, de modo a não prejudicar sua reputação e perder vendas futuras" (BRASIL, 1996a, p. 79).

Em seu voto em Recofarma/Leão Jr, o então Conselheiro Paulo Furquim de Azevedo também esclareceu que o detentor de uma marca tem interesse na manutenção da qualidade dos produtos e serviços. Do contrário, ela perderá sua capacidade de transmitir informação e não terá mais valor à empresa (BRASIL, 2009a). ${ }^{9}$

Pode-se dizer que a marca incentiva a manutenção do nível de qualidade dos produtos na medida em que a sua reputação deve ser preservada a fim de não prejudicar as vendas da empresa.

Nessa linha, explica Barzel (1982, p. 36) que o valor da marca decorre de sua capacidade em "garantir que o produto é - e permanecerá - uniformemente bom”, sendo o seu valor equivalente à "economia de custos de mensuração de informação a respeito de atributos do produto".

Essa característica da marca de incentivar a manutenção de padrões de qualidade é bastante discutida pela Escola de Chicago e utilizada como um argumento importante para conferir proteção legal ao instituto, conforme será discutido em mais detalhes na seção 1.3.2 adiante.

\subsubsection{Marca enquanto criadora de mercado e direcionadora da demanda}

A marca não apenas identifica um produto ou serviço e o diferencia dos demais. Sua função é que a diferenciação seja de tal grau e relevância que o produto se

\footnotetext{
${ }^{9}$ Afirma Paulo Furquim de Azevedo em seu voto em Recofarma/Leão Jr. que: "[U]ma marca pode, portanto, depreciar se perder a capacidade de transmitir a informação, o que pode ocorrer se houver alguma frustração das expectativas do consumidor após o consumo. Dito de outro modo, se um consumidor escolhe um produto tendo a marca como um elemento de apoio à decisão, sua experiência de consumo deve confirmar as informações sobre os atributos do produto transmitidos pela marca, caso contrário, esta perde a capacidade de transmitir informações e, portanto, perde valor. Por esse motivo, aquele que detém uma marca de elevado valor tem interesse econômico na manutenção dos padrões de qualidade de seus produtos e serviços, de modo a manter o valor desse ativo. Diante disso, o consumidor toma uma marca que goze de reputação como sinal crível sobre a qualidade do produto. $\mathrm{O}$ mesmo não ocorreria com uma marca sem valor, que não está associada, pela experiência de consumo, a um padrão de qualidade" (BRASIL, 2009a, p. 11-12).
} 
torne necessário ao consumidor ${ }^{10}$ e faça com que os produtos concorrentes tornem-se irrelevantes. É preciso alcançar um grau de diferenciação que efetivamente crie preferências no consumidor, a partir das quais seja possível desenvolver uma relação de lealdade, que, por sua vez, possibilite a sustentação do produto no mercado.

A ideia é que a marca crie referenciais que "a credenciam no mercado, dando sentido, vida e dinamismo a tal ponto de poder estabelecer a preferência pelo produto, não só influenciando o consumidor, como também determinando padrões de comportamento" (SERRALVO, 2009, p. 87).

Essa capacidade de criar referenciais mercadológicos ocorre sobretudo no campo simbólico do produto. A marca faz com que o produto se destaque de sua realidade instrumental, funcional, trazendo uma dimensão figurativa ou simbólica para o produto com "enorme força imagética capaz de produzir sonhos, fantasias, processos de projeção e identificação. Essa é uma das principais funções das estratégias de comunicação de marca" (NORBERTO, 2004, p. 210).

É dentro dessa dimensão simbólica que as relações de concorrência entre as empresas se estabelecem com maior força, ${ }^{11}$ na medida em que cada empresa, por meio de sua marca e de toda a estratégia comercial por detrás dela (e.g. sistema de vendas, distribuição, programas de fidelidade, etc.), deseja tornar o produto mais relevante para o consumidor e assim, fidelizá-lo.

Para Norberto (2004), as características funcionais dos produtos estão sujeitas a uma descontinuidade permanente, em virtude dos processos de inovação. Porém, a marca surge como um elemento estabilizador, uma vez que cria uma relação de lealdade entre consumidor e produto ou serviço.

Do ponto de vista do professor de marketing David Aaker, o objetivo principal de uma empresa, por meio das marcas, é criar uma subcategoria de produto que se diferencie e se destaque perante as demais, tornando concorrentes irrelevantes.

\footnotetext{
${ }^{10} \mathrm{Na}$ competição por diferenciação, as firmas concorrem procurando transformar seus produtos em únicos com relação ao dos competidores (BRASIL, 1996a, p. 79).

${ }^{11}$ Nas palavras de Norberto (2004, p. 206-207), “(...) em todos os momentos, a disputa concorrencial se dá também na esfera simbólica. Cada corporação deseja transformar seu objeto inovador num produto significativo e, portanto, útil para determinadas categoriais sociais. Em outras palavras, cada uma delas tenta fazer com que seu produto seja ainda mais útil do que os concorrentes, pois esse tipo de concorrência tem como objetivo alterar a hierarquia das preferências dos compradores em potencial. Portanto, o sucesso comercial da organização e, consequentemente, sua própria sobrevivência dependem não apenas de seu desempenho tecnológico, produtivo, mas igualmente dos resultados obtidos na esfera simbólica (...) são as marcas que permitem o estabelecimento de relações estáveis com os consumidores".
} 
Nas palavras desse autor, "It seems clear that success is about winning not the brand preference battle but, rather, the brand relevance war with an innovative offering that achieves sustainable differentiation by creating a new category or subcategory" (AAKER, 2011, p. xiii).

Diante do exposto, resta claro que essa função diferenciadora está intimamente ligada ao processo de alteração da preferência dos consumidores pela marca e ao desenvolvimento de uma relação de fidelização do comprador. Com isso, a marca possibilita a sustentação de um produto no mercado, a criação e/ou o redirecionamento da demanda, a redução (ou eliminação) da concorrência com produtos que seriam funcionalmente similares ou idênticos e a cobrança de preços supracompetitivos.

Para Salomão Filho (2006), a marca é, inclusive, um meio de criação de monopólios, que incorpora a reputação de um bem e pode concentrar preferências. Essa capacidade de criação de monopólios pode ser explicada pelo grau de diferenciação criado por determinada marca. Quanto mais diferenciado é um produto, mais baixa é a sua elasticidade com relação a preços. Dessa maneira, maior é a capacidade de atuação da empresa como um monopolista na medida em que pode aumentar o seu preço sem que os consumidores se desviem para os produtos de concorrentes ${ }^{12}$.

\subsubsection{Marca enquanto barreira à entrada}

A identificação da marca como uma barreira à entrada é corrente na doutrina além de estar presente em vários guias de análise econômica de atos de concentração publicados por autoridades concorrenciais ${ }^{13}$. A diferenciação de produtos,

\footnotetext{
${ }^{12}$ De acordo com Lúcia Helena Salgado em seu voto em Colgate/Kolynos, "Uma estratégia bem sucedida de diferenciação leva no limite a que o consumidor não identifique substitutos para o produto de um fabricante e assim aceite aumentos de preços sem procurar alternativas de consumo" (BRASIL, 1996a, p. 79).

${ }^{13}$ O Guia Brasileiro para Análise Econômica de Atos de Concentração horizontal identifica a fidelidade do consumidor às marcas como barreiras à entrada: "52. Definições. Barreiras à entrada podem ser definidas como qualquer fator em um mercado que ponha um potencial competidor eficiente em desvantagem com relação aos agentes econômicos estabelecidos. Os seguintes fatores constituem importantes barreiras à entrada: (...) (f) a fidelidade dos consumidores às marcas estabelecidas" (BRASIL, 2001). Os Comentários ao Guia Norte-Americano de Análise de Concentração Horizontal de 2006 (2006 Commentary on the Horizontal Merger Guidelines) também ressalta a dificuldade de entrada em um mercado com marcas bem estabelecidas, dado os gastos com publicidade e preços promocionais: As agências comumente concluem que atos de concentração envolvendo produtos altamente diferenciados
} 
particularmente quando acompanhada de largas quantidades de publicidade da marca, pode impedir a entrada ao não permitir a concorrentes potenciais uma oportunidade para alocar um nicho rentável no mercado. A diferenciação de produtos e a publicidade da marca alimentam-se um do outro para criar uma barreira à entrada (HOVENKAMP, 2005).

Consumidores leais a determinada marca estão menos propensos a experimentar uma nova marca. Para superar esse problema, os entrantes têm de investir em preços para encorajar os consumidores a comprarem seus produtos e, ainda, realizar gastos com publicidade para fazer frente às firmas já estabelecidas no mercado. ${ }^{14}$ (OECD, 2005, p. 37).

Nesse contexto, os entrantes estão em posição de desvantagem em relação às marcas já estabelecidas seja porque o custo de propaganda por unidade de produção incorrido pelos primeiros serão maiores - já que, inicialmente, não desfrutam de economias de escala -, seja porque as empresas estabelecidas no mercado já detêm a preferência do consumidor.

O tema da marca enquanto fator de barreira à entrada tem fortes implicações na análise de atos de concentração envolvendo mercados diferenciados e na

não atrairiam a entrada de novas marcas porque a entrada não seria rentável a preços pré-operação. Em um mercado repleto de marcas bem estabelecidas, uma entrada bem sucedida geralmente requer um investimento substancial em propaganda e atividade promocional durante um longo período de tempo a fim ganhar participação e atingir ampla distribuição nos canais de varejo. Ademais, a realização desses investimentos de maneira alguma garante sucesso" (tradução livre) (BRASIL, 1996b, p. 38).

${ }^{14}$ A noção de marca como uma importante barreira à entrada no mercado também é explicada de forma bastante clara por Demsetz (DEMSETZ, 1982, p. 50) em seu clássico artigo "Barriers to Entry": "Because of brand loyalty, new rivals, seeking to sell as much as existing firms, may need to advertise more than existing firms (or offer some other compensating advantage). This may be required at the time of entry even though new and old firms produce the 'same' product, and even though old firms may have had to advertise even more to promote a new product variety when they began to sell. Advertising expenditures, at least those incurred earlier by existing firms, may be called a source of 'barriers' to entry. However, investments in advertising and promotion are worthwhile (for both old and new firms) only in the presence of significant information costs. Information costs are the more fundamental barrier to entry. These costs, not necessarily in identical amounts, constitute hurdles to all who would (and have) enter(ed) the industry. Complete knowledge about products and firms would make brand loyalty useless from both consumer and seller viewpoints. Where advertising and promotion are used extensively, and, therefore, where goodwill and brand loyalty are assets, there must also exist real costs of resolving uncertainties. In the presence of such costs, consumers will find it useful to rely on a firm's experience and reputation, or more correctly, on its history or on the fact that it has made sizeable investments specific to this industry. New firms and recent entrants by virtue of their shorter histories or absence of specific investments (in particular, product lines) may not be able to impart to consumers, without some compensating effort, the same confidence as has already been secured by older firms through past investments in good performance. If new firms are to sell equal quantities at equal prices, they may need to incur higher costs of persuading and communicating than presently is required of older firms". 
análise de condutas e será retomado com mais detalhes nos Capítulos 3 e 4 deste trabalho.

\subsubsection{Marca e inovação}

A associação entre marca e inovação não é direta. Afinal, o único requisito para o registro de uma marca é a novidade do símbolo em si, mas não do produto (como no caso das patentes). Em outras palavras, não é necessário um produto inovador para que a marca seja registrada.

No entanto, as marcas estão ligadas às atividades inovadoras das firmas. Conforme apontado pela Comissão Europeia em decisão sobre a fusão KimberlyClark/Scott, "Effective competition in the branded segment is important because branded (...) products promote innovation and product quality improvement". Reconheceu, ainda, a autoridade que “(...) It is well established in almost all consumer product markets that product innovation is pioneered by branded producers (...)" (EUROPA, 1996, p. 43).

Quando se considera que produtores com marcas bem sedimentadas no mercado são capazes de praticar preços com lucros monopolísticos, é possível imaginar que parte desse lucro possa ser aplicada, dentre outros destinos, em promoção de inovações do produto ou serviço que carrega determinada marca.

Se, por um lado, marcas bem sucedidas são fundamentais para que o fabricante mantenha o produto no mercado extraindo resultados supracompetitivos, por outro, o produto não se manterá se não acompanhar as inovações do mercado. Dentro dessa linha, é de se supor que haja certa relação de retroalimentação entre os lucros auferidos por produtores com marcas bem sucedidas e o investimento em inovação (embora boa parte desses lucros também possa ser destinada à publicidade constante da marca). Essa relação será tanto mais intensa quanto mais o mercado do produto ou serviço em questão for marcado por inovações.

Ademais, a marca parece importante não só para financiar, em certa medida (a partir dos lucros monopolísticos que gera), as inovações dos produtos, mas também para promovê-las. De fato, produtos inovadores são associados a novas marcas, 
as quais são utilizadas pelas empresas para criar no consumidor a percepção da inovação e, assim, torná-lo leal ao novo produto. Com isso, a marca constitui um meio para a apropriação dos benefícios da inovação ${ }^{15}$ (MILLOT, 2009).

Dessa maneira, embora a marca não exija a inovação do produto em si para ser registrada, ela é um importante instrumento comercial utilizado pelas firmas para lançarem suas inovações no mercado e para criarem o desejo no consumidor de usufruírem o produto, fidelizando-o e, assim, criando um mercado sólido para a sua distribuição.

Importante notar, todavia, que a marca não é o único meio de apropriação da inovação. Podem ser usadas isoladamente ou em conjunto com outros mecanismos tais como patentes e segredos de indústria. Algumas firmas notadamente as utilizam em complementação às patentes. É o caso das empresas da indústria farmacêutica. Elas constroem a reputação da marca durante o período de vigência da patente e, uma vez que essa expira, conseguem manter poder de mercado graças à marca estabelecida. ${ }^{16}$

As marcas também contribuem para promover a comercialização de produtos protegidos por segredo de indústria ${ }^{17}$. Nesses casos, o uso da marca permite a apropriação dos retornos do produto ainda que o segredo seja divulgado.

Ademais, de acordo com Davis (2006), as marcas incentivam as companhias a investirem em inovação incremental. Esse tipo de inovação refletiria melhorias incrementais nos produtos e serviços existentes de forma a torná-los melhores ou mais baratos a fim de aumentar as chances de sucesso comercial. Tais inovações não seriam patenteáveis, pois de menor relevância, mas ainda assim poderiam ser protegidas e apropriadas por meio da proteção legal à marca.

\footnotetext{
${ }^{15}$ Millot afirma ainda que "In practice, however, trademarks are likely to be linked to the innovative activity of firms, at various levels. First, trademarks play a role in the commercialization of new products. When they launch an innovation, firms may associate it to a new brand in order to help the perception of the innovation by consumers. The brand constitutes a basis on which firms advertise their product. Then the trademark has good chances to become a, or even the reference on the market for the product. Indeed the consumers who start buying one innovative product of one brand are likely to remain loyal to this brand. It is then difficult for competitors to enter the market. Thus trademarks can constitute a means to appropriate the benefits of an innovation. Various product innovations by firms are then associated to a trademark (e.g.the "Kleenex", invented in 1924 by the firm Kleenex; the "Walkman", first launched by Sony in 1979; the "i-phone", launched by Apple in 2007)" (2009, p. 6).

${ }_{16}$ Nesse sentido, explica Davis que "(...) drug companies have made frequent use of trademarks. Trademark-based advertising can help the firm market its drugs aggressively to hospitals, doctors, and directly to patients. The goal is to convince patients (and doctors) to continue to prefer their drug after the patent expires even though its price is higher than generic copies" (DAVIS, 2006, p. 13).

${ }^{17}$ A título ilustrativo, pode-se citar a estratégia da Coca-Cola.
} 
Para esse autor, as marcas são adequadas para inovações incrementais porque é muito mais fácil e barato para uma empresa registrar uma nova marca para proteger os frutos de sua estratégia de diferenciação de produto do que obter uma nova patente. A maioria das inovações incrementais representam somente mudanças muito pequenas sobre os bens existentes, nenhuma das quais representa o requisito de inventividade necessário à proteção patentária (DAVIS, 2006).

Embora até o momento tenham sido ressaltados fatores em que a marca contribui para a inovação, é importante ressaltar que ela também pode ser um instrumento bloqueador da inovação. Conforme mencionado acima, a marca pode ser uma barreira à entrada e, nesse sentido, impedir a entrada de firmas inovadoras no mercado. Nesse sentido, uma firma não inovadora que tenha extensivos investimentos em marcas poderá desestimular a entrada de uma empresa inovadora.

Diante disso, constata-se que os efeitos da marca sobre inovação podem ter dois lados. A literatura a respeito da relação entre marca e inovação ainda é escassa e há muitas questões a serem estudadas (DAVIS, 2006).

\subsection{Justificativas para proteção legal à marca}

\subsubsection{Visão Clássica}

São várias as justificativas para garantir proteção às marcas. As justificativas clássicas residem na proteção ao investimento do empresário em sua imagem e de seus produtos ou serviços e também na proteção do consumidor contra confusão.

O primeiro fator relaciona-se com a proteção ao fundo de comércio da empresa na medida em que a marca reflete investimentos na construção ou manutenção de uma reputação. Nesse sentido, a proteção à marca estaria ligada, de uma forma mais ampla, à proteção desse conjunto de atributos intangíveis que são fundamentais para a construção da reputação de uma empresa e determinantes para o seu sucesso no mercado. 
Nesse esteio, é possível dizer que a proteção à marca está a trabalho da livre iniciativa, entendido, por Forgioni (2012), como uma garantia aos agentes econômicos de "ingresso ao mercado, à arena de disputas" e também de permanência nele.

Todavia, para que a liberdade empresarial possa ser exercida efetivamente e o agente econômico possa projetar-se no plano da produção, circulação e distribuição de riquezas, é necessário algumas garantias, dentre elas, a proteção a determinados direitos que assegurem o exercício daquela liberdade. Nesse plano, inserese o direito marcário.

Sem a proteção à imagem construída pela empresa por meio de seus produtos e/ou serviços e à sua reputação, a livre iniciativa não se consubstancia na medida em que free riders poderiam se aproveitar do fundo de comércio construído por determinada empresa. Conforme entendimento da Suprema Corte norte-americana em Qualitex Co. v. Jacobson Prods. Co. Inc., “(...) the law helps assure a producer that it (and not an imitating competitor) will reap the financial, reputation-related rewards associated with a desirable product" (EUA, 1995).

Além disso, o direito marcário também tem por justificativa proteger o consumidor de condutas enganosas e que o induzam à confusão (LAFRANCE, 1958). Esse pressuposto da proteção marcária - evitar a confusão e o locupletamento do consumidor - é amplamente reconhecido pela doutrina e jurisprudência brasileiras (DIAS, 2013).

\subsection{2. $\quad$ A Escola de Chicago}

A Escola de Chicago trouxe explicações econômicas que deram maior embasamento às justificativas clássicas para proteção à marca. Nesse sentido, defende que a proteção a este instituto se deve à redução dos custos de busca que ela garante ao consumidor, à maior qualidade que imprime aos produtos, sinalizando ao consumidor a consistência nos atributos do produto que este adquire, e ao combate de free riders que queiram se aproveitar da reputação e esforços alheios. Todos esses fatores, na visão desta corrente de pensamento, também justificam preço supracompetitivo do produto que carrega uma marca. 
(i) Redução de search costs

Para essa corrente, a proteção à marca é fundamental na medida em que facilita ao consumidor a identificação do produto e reduz os seus custos de busca ("search costs"), além de encorajar as empresas a investirem em qualidade.

Ao trazer informações sobre o produto, a marca permite que $o$ consumidor o associe a elas. Em tendo conhecimento prévio sobre suas características, não terá que, futuramente, despender tempo buscando um produto com as mesmas propriedades, simplesmente adquirirá aquele com a marca já conhecida.

Kitch e Perlman (1998), defensores de uma proteção marcária mais ampla e expansiva, acreditam que os consumidores são beneficiados seja pela propaganda, seja pela identificação da origem do produto. Essa visão encontra respaldo nas teorias baseadas em Stigler (1961). Na perspectiva de Stigler, os consumidores enfrentam dois custos separados ao comprar um produto: o custo nominal do produto e os custos de informação associados à busca pela compra do produto certo. Os vendedores geralmente podem reduzir os custos de informação por meio da propaganda, mas o farão se puderem identificar seus produtos. Da mesma forma, se as marcam sinalizam uma qualidade constante, os consumidores, uma vez que encontrarem seu produto preferido, podem evitar custos repetidos de busca e experimentação ao confiar em uma marca favorita. Dentro dessa visão, as marcas (e propaganda) beneficiam os consumidores ao reduzirem o custo de busca que compõe o preço que eles pagam por suas compras.

Por essa razão, um dos núcleos fundamentais da proteção das marcas para a Escola de Chicago é a redução dos custos de busca (search costs) ${ }^{18}$. Essa visão está associada à proteção do consumidor contra confusão justamente porque entende que a marca carrega informações relevantes sobre o produto, que auxiliam o usuário a buscar exatamente o que consumiu anteriormente. Ao proteger esse instituto, o sistema

\footnotetext{
${ }^{18}$ Segundo Landes e Posner (1987), deveria estar claro que os benefícios das marcas na redução dos custos de busca dos consumidores pressupõem a proteção legal das marcas. $\mathrm{O}$ valor das marcas é a economia dos custos de busca possibilitada pela informação ou reputação que a marca carrega ou incorpora sobre o signo (ou sobre a empresa que produz a marca). Criar essa reputação exige gastos na qualidade do produto, serviço, publicidade e assim por diante. Uma vez que a reputação é criada, a empresa obterá maiores lucros porque compras repetidas e referências do tipo boca a boca gerarão mais vendas e porque os consumidores tenderão a pagar maiores preços por menores custos de busca e maior garantia de qualidade consistente.
} 
jurídico permite que essas informações sejam devidamente transmitidas aos consumidores de modo a permiti-los identificar adequadamente aquilo que desejam adquirir. Decisões judiciais norte-americanas sobretudo na década de 80 , quando a Escola de Chicago estava no auge, refletem essa abordagem. ${ }^{19}$

Investimentos em publicidade é sinônimo de qualidade

De fato, para essa escola, a redução dos custos de busca dos consumidores é a razão e o pressuposto da sua proteção, a qual tem importantes efeitos na competitividade do mercado. Dentre esses efeitos, a proteção marcária estimularia a manutenção da qualidade do produto. As firmas que recebem proteção marcária devem investir na qualidade do produto, pois, se esta não for consistente ao longo do tempo, perderão vendas na medida em que a marca não mais carregará informações válidas sobre o produto ou serviço, perdendo, pois, sua função, e desestimulando o consumo. ${ }^{20}$

Além disso, defende-se que quanto mais investimentos em marca e propaganda são realizados pelas empresas, mais se sinaliza ao consumidor que terão prejuízos caso forneçam um produto abaixo da qualidade geralmente praticada. Em outros termos, os prejuízos com a quebra de expectativa do consumidor caso comercializassem um produto de qualidade inferior seria diretamente proporcional ao

\footnotetext{
${ }^{19}$ A título ilustrativo, em Scandia Down Corp. v. Euroquilt, Inc. (EUA, 1985), o juiz Easterbrook assim descreveu os benefícios econômicos que essa corrente atribuía às marcas: "Trademarks help consumers to select goods. By identifying the source of the goods, they convey valuable information to consumers at lower costs. Easily identified trademarks reduce the costs consumers incur in searching for what they desire, and the lower the costs of search the more competitive the market. A trademark also may induce the supplier of goods to make higher quality products and to adhere to a consistent level of quality".

${ }^{20}$ Assim, explicam Landes e Posner (1987) que os benefícios das marcas na redução dos custos de busca do consumidor exigem que o produtor do produto com marca mantenha uma qualidade consistente ao longo de tempo em relação aos consumidores. Dessa forma, a proteção da marca encoraja gastos com qualidade. No entanto, para que essa estratégia seja eficiente, não deve ser apenas mais barato procurar a marca correta do que os atributos desejados para o produto, mas também a experiência pretérita deve ser uma boa previsão do possível resultado das escolhas atuais de consumo. De maneira menos óbvia, o incentivo de uma empresa de investir em recursos para desenvolver e manter (por meio de publicidade) uma marca forte depende de sua habilidade de manter uma qualidade consistente do produto. Em outras palavras, as marcas têm uma característica de retroalimentação. Elas são relevantes porque denotam qualidade constante, e uma empresa tem incentivo para desenvolver uma marca somente se ela estiver apta a manter qualidade consistente. Se a qualidade de uma marca é inconsistente, os consumidores aprenderão que a marca não os torna aptos a relacionarem sua experiência de consumo passada à futura. Assim, o produto com marca será como um produto sem marca. Nesse caso, a marca não irá diminuir os custos de busca, de maneira que os consumidores não estarão tendentes a pagar mais pelo produto com marca do que pelo produto sem marca. Como resultado, a firma não ganhará um retorno suficiente sobre os seus gastos em publicidade e marca.
} 
tamanho do investimento em propaganda. Como não seria do interesse da empresa quebrar essa expectativa, haja vista os grandes prejuízos financeiros decorrentes, o consumidor teria mais uma segurança ou garantia quanto à consistência de qualidade do produto ao longo do tempo (KLEIN; LEFFLER, 1981).

\section{Proteção contra free riders e construção da reputação da empresa}

A Escola de Chicago também sustenta que a proteção à marca é importante para a construção e proteção da reputação de uma empresa. Trata-se de uma relação de mão dupla. Por um lado, ela incentiva as empresas a manterem a qualidade constante em um produto. Por outro, essa qualidade consistente é fundamental para o desenvolvimento da reputação de uma empresa. Sem a proteção marcária, as empresas teriam dificuldades para construírem uma imagem no mercado e desenvolverem-se, uma vez que poderiam ser objeto da ação prejudicial de free riders.

\section{Preço supracompetitivo do produto com marca é justificado por benefícios adicionais}

Todos esses benefícios advindos da proteção marcária têm, segundo a Escola de Chicago, uma implicação fundamental: o preço do produto com marca é maior (preço supracompetitivo) na medida em que o consumidor estaria recebendo um benefício adicional que deveria ser remunerado. Esse benefício seria traduzido em (a) informação adequada acerca dos atributos do produto, ${ }^{21}$ (b) maior qualidade ${ }^{22}$ e (c)

\footnotetext{
${ }^{21}$ Importante ressaltar que essa visão de que a marca informa adequadamente os consumidores sobre os atributos e a qualidade do produto é fortemente criticada pela Escola de Harvard. Os seguidores da Escola de Chicago tendem a ignoram a dimensão persuasiva da marca, dando ênfase apenas à dimensão informacional. No entanto, tanto o aspecto informacional quanto o persuasivo estão presentes e devem ser analisados em conjunto. Os efeitos da dimensão persuasiva não são desprezíveis: ela altera as preferências e desejos do consumidor e, assim, tem impacto direto sobre a orientação da demanda. Esse ponto será discutido de maneira mais detalhada na seção 1.1.3 abaixo.

${ }^{22}$ Segundo Klein e Leffer (1981, p. 632), "This analysis of advertising implies that consumers necessarily receive something when they pay a higher price for an advertised brand. An expensive name brand aspirin, for example, is likely to be better than unadvertised aspirin because it is expensive. The advertising of the name brand product indicates the presence of a current and future price premium. This premium on future sales is the firm's anticipated quality. Therefore, firms selling more highly advertised, higher priced products will necessarily take more precautions in production".
} 
maior segurança de qualidade consistente ao longo do tempo. Esse entendimento leva à crença de que a publicidade da marca teria apenas consequências pró-competitivas (BAGWELL, 2007).

Com efeito, na visão da Escola de Chicago, a marca em si só é vista sob o aspecto pró-competitivo. A justificação do preço monopolístico de um produto com marca segue uma racionalidade econômica (LANDES; POSNER, 1988) na medida em que a marca reduz os custos do consumidor e incentiva a manutenção da qualidade dos produtos. Com isso, traz-se eficiência ao mercado, a qual sempre é uma justificativa para a obtenção ou manutenção de posição dominante no entender desta corrente doutrinária (SALOMÃO FILHO, 2007).

Conforme se verá abaixo, todavia, as marcas não têm somente efeitos pró-competitivos. Os contrapontos às ideias da Escola Chicago serão expostos na seção 1.3.3, a seguir.

\subsubsection{Críticas à proteção ampla às marcas: o Estruturalismo de Harvard}

Conforme verificado acima, a Escola de Chicago defende que as marcas geram eficiências no mercado, uma vez que reduzem os custos de informação dos consumidores e geram incentivos de controle de qualidade. Dessa maneira, são vistas, segundo essa teoria, como eminentemente pró-competitivas.

Antes do advento dessa corrente, todavia, e sobretudo a partir das décadas de 60 e 70, criticava-se a noção de que a marca pressupõe qualidade. Ademais, havia a ideia de que as marcas eram "mecanismos para preservação do poder de mercado" e, dessa forma, poderiam ser "anticompetitivas" (MCCLURE, 1996).

\section{(i) Marca não necessariamente pressupõe qualidade}

A fazer uma releitura das obras de Bain, economista ligado ao estruturalismo da Escola de Harvard, em especial, os trabalhos "Barriers to New Competition" (BAIN, 1956) e "Industrial Organization" (BAIN, 1959), Mueller (1968) 
aponta que a marca, na realidade, gera uma falsa ideia de qualidade. Na medida em que os produtos efetivamente diferenciados são complexos e apresentam uma série de funcionalidades alheias ao conhecimento do consumidor, a este resta confiar em uma pretensa ideia de qualidade veiculada pela publicidade em torno de um produto.

Com efeito, doutrinadores contemporâneos da área de publicidade e marketing apontam para uma crise de legitimidade da marca na medida em que ela, muitas vezes, não tem correspondido à qualidade esperada pelo consumidor. Nessa linha, Semprini (2010, p. 36-37) esclarece que:

"A demanda de qualidade cresceu em uma velocidade que as grandes marcas nem sempre conseguem acompanhar. As marcas aventuram-se por territórios que têm dificuldade para dominar, assim como o controle de sua produção industrial, e principalmente, a opinião parece querer-lhe virar as costas. As marcas estão no banco dos réus, a confiança nas empresas está em baixa.

Nesse contexto, esta perspectiva alerta para o fato de que aquela relação direta entre marca e qualidade defendida pela Escola de Chicago pode não ser sempre válida.

O problema de assimetria informacional do consumidor é denominado por Bain de "ignorância do consumidor" ${ }^{23}$. Essa ignorância alimenta a diferenciação do

\footnotetext{
${ }^{23}$ Ao explicar o conceito de ignorância do consumidor elaborado por Bain, Mueller (1968, p. 29-30) anota o seguinte: "The principal source of 'product differentiation', then, is what Bain calls 'buyer ignorance'. In general, the susceptibility of consumers to successful 'product differentiation' is in direct proportion to their lack of factual information about the qualities and characteristics of the goods they are purchasing and their lack of an adequate opportunity to acquire such information. Thus the bulk of the highly 'differentiated' products falls into one or more of the following categories: 1 . They are bought by consumers, rather than producers; 2. They are fairly durable in character and are thus purchased infrequently (a factor that tends to prevent the consumer from "experimenting" and thus becoming familiar with all or most of the competing brands); 3 . They are complex in design or composition, thus making it impractical for the consumer to attempt to acquire the technical knowledge that would be needed in order to make an informed choice between the various brand offerings. As Bain puts it: 'with respect to the meat, canned vegetables, bread, stockings, and similar goods purchased repeatedly at short intervals, a housewife is likely to acquire a reasonably good knowledge of the quality and other characteristics of competing outputs, and to arrive at a reasoned and informed choice among alternatives. With respect to automobiles, major electrical appliances, home-movie cameras, and the like,' however, goods that are complex in design and very infrequently purchased, 'the average consumer is likely to have only the sketchiest notion of the relative performance, reliability, and other essential characteristics of competing brands, and is in effect ignorant or uninformed. In this situation,' Bain suggests, 'the buyer is likely to rely on the 'reputations' of the various products or their sellers; on popular lore concerning the performance and reliability of past outputs of a seller, on whether or not the seller has successfully remained in business for a long time, and so forth. This reliance on seller or product reputations by ignorant consumers,' he believes, is thus one of the major sources of the kinds of
} 
produto. Uma vez que o consumidor não tem informações plenas ou ao menos suficientes sobre diversos aspectos do produto, cada (suposto) novo atributo criado pelo produtor seria um fator de diferenciação.

A título ilustrativo, ainda que uma nova atualização de um sistema operacional de computador ou de um smart phone, na prática, não incorpore modificações substanciais que o aprimorem de forma significativa, o mero lançamento de um novo sistema com funcionalidades que nem os próprios consumidores entendem de forma adequada, mas que possuam a aparência de serem mais complexas ou diferenciadas, pode induzir o consumo e aumentar a competitividade de determinado produto.

É por meio da ignorância do consumidor, segundo Bain, que a persuasão, característica da publicidade que permeia as marcas, consegue adentrar e, assim, influenciar e orientar as escolhas de consumo do indivíduo. É nesse sentido que esse autor põe em dúvida o caráter informacional da publicidade e ressalta a sua natureza persuasiva, a qual busca perscrutar o irracional e o emocional nas mentes do consumidor a fim de guiar sua opção de $\operatorname{compra}^{24}$ (MUELLER, 1968).

\section{Marca como mecanismo de preservação de poder de mercado: barreiras à entrada como pressuposto fundamental}

A ideia de marca como mecanismo de preservação de poder de mercado encontra em sua essência as teorias dos economistas de Harvard, Edward Chamberlin e Joe Bain. Essas teorias levaram à noção de que a marca, na realidade, é uma barreira à

\footnotetext{
'preference' patterns that breed high concentration and the other undesirable consequences of inordinately high degrees of 'product differentiation"".

${ }^{24}$ Nesse sentido, ao comentar as ideias de Bain, Mueller (1968, p. 30) explica que "This lack of reliable factual information on the part of the consumer plays a still further role in the story, however. Most importantly of all, perhaps, it makes her susceptible to what Bain calls the 'persuasive sales-promotion activities of sellers,' particularly advertising of a certain kind: Inextricably interconnected with brands, trademarks, or company names, advertising and other sales promotion may of course be primarily 'informational' in its impact (thus tending to build a product differentiation based on a knowledge of the relative designs, qualities, and prices of competing outputs), but in our experience it is, instead, primarily 'persuasive.' It is aimed at creating product preferences through generally phrased praises of the attributes of various outputs (...), or simply through dinning into the potential buyer's mind an awareness of the product through endless repetition. Thus an important category of product differentiation is built primarily on a non-rational or emotional basis, through the efforts of the 'ad-man".
} 
entrada que pode ser utilizada para aumentar ou preservar o poder de mercado de agentes econômicos.

Chamberlin, em sua obra "The Theory of Monopolistic Competition" (CHAMBERLIN, 1933), analisa a marca de forma inovadora, isto é, como instrumento de diferenciação entre as empresas que resulta em um poder monopolístico para cada uma delas. Em outras palavras, cada uma delas tem certo nível de poder de monopólio naqueles produtos específicos que comercializam. Embora esses concorram com produtos fabricados por outras empresas, a diferenciação, que resulta numa preferência do consumidor por aquele produto, assegura ao agente o poder monopolístico.

O modelo de concorrência monopolística elaborado por Chamberlin, portanto, mostra que, de um lado, a diferenciação de produtos gera um benefício decorrente do aumento das possibilidades das características do produto se adequarem ao gosto do consumidor. Por outro lado, a criação de novos produtos gera maiores custos fixos associados aos esforços de venda (gastos em publicidade e outras estratégias de marketing) (KUPFER; HASENCLEVER, 2002).

Para o autor, o aumento desses custos fixos relacionados aos esforços de vendas com o desenvolvimento da marca não eram barreiras à entrada especificamente. A ideia de marca como barreira à entrada foi desenvolvida mais tarde como consequência dos trabalhos de Joe Bain (1956) e outros autores. ${ }^{25}$

Atualmente, segundo Kupfer e Hasenclever (2002), há unanimidade entre os economistas industriais de que a diferenciação de produto é a mais forte dentre as barreiras. São amplas as possibilidades de criação de vantagens da incumbente baseadas nas preferências dos consumidores. De modo geral, pode-se esperar que a empresa entrante depare-se com a necessidade de deslocar preferências consolidadas pelas marcas das empresas estabelecidas, o que poderá ser muito custoso, pois a qualidade do produto oferecido pela empresa entrante é incerta para o consumidor. Essas vantagens da incumbente são particularmente intensas nas indústrias de bens duráveis - porque a pouca repetição do ato de compra dificulta o aprendizado do consumidor - e de maior valor unitário - porque os custos do 'arrependimento', que são proporcionais ao valor do bem serão bem altos.

\footnotetext{
${ }^{25}$ Scherer (1977) e Demsetz (1982).
} 
Assim, conforme discutido na seção 1.2.3 acima, a marca é uma barreira à entrada significativa na medida em que estabelece fortes preferências nos consumidores. Nesse sentido, as firmas que desejem entrar no mercado terão de incorrer em custos substanciais para deslocar as preferências desses consumidores, seja por meio de investimentos em publicidade e propaganda, seja por qualquer outra medida compensatória (i.e. ações promocionais). Portanto, as empresas já estabelecidas no mercado têm vantagens de custos, pois já têm uma reputação e, assim, a confiança dos consumidores. Obviamente, a discussão de marcas como barreiras à entrada só faz sentido num contexto de informação imperfeita, em que o conhecimento do consumidor sobre as características e qualidades dos produtos e serviços não é plena, o que é, em geral, uma constante na maioria dos mercados de bens de consumo.

Importante notar, todavia, que a Escola de Chicago negava veementemente que as marcas fossem barreiras à entrada, expurgando-lhes qualquer caráter anticompetitivo. Para os autores desta corrente, "all of the 'artificial barriers' complained of in antitrust are, in fact, activities that create efficiency" (POSNER, 1979, p. 930). A Escola de Chicago argumentava que qualquer poder de mercado associado à marca é derivado simplesmente da preferência do consumidor pelo produto de marca e, portanto, não seria uma barreira à entrada anticompetitiva com a qual a legislação antitruste devesse se preocupar (MCCLURE, 1996, p. 24-25).

As justificativas da Escola de Chicago, ao desconsiderar as marcas como barreiras à entrada, são vistas como "semantic waffling" por importantes economistas adeptos à corrente estruturalista de Harvard. Estes deixam claro que uma marca forte pode conferir significativo poder monopolístico, sobretudo em indústrias de bem de consumo (SCHERER, 1977).

(iii) O Caso ReaLemon: precedente ilustrativo do pensamento da Escola Estruturalista

$\mathrm{O}$ auge do pensamento segundo o qual as marcas, enquanto barreiras à entrada, confere poder de mercado ao agente econômico está refletido no caso ReaLemon. 
Em 1974, o Federal Trade Commission - FTC iniciou uma investigação contra a empresa Borden, Inc., que estaria violando o $\$ 5^{\circ}$ do Federal Trade Commission Act, o qual proíbe métodos desleais de concorrência.

Em resumo, a Borden, Inc., uma produtora de suco de limão processado, foi investigada por praticar preço predatório em regiões específicas onde enfrentava a concorrência de produtores locais. Dentre outros fatores, a presença de uma marca dominante (denominada ReaLemon), a capacidade de praticar preços acima dos níveis competitivos em decorrência das fortes preferências dos consumidores em relação a essa marca e o poder da marca de controlar preços e a entrada no mercado foram elementos determinantes para caracterizar o poder de monopólio da empresa no segmento de suco de limão processado, nos termos da decisão inicial proferida pelo juiz administrativo do FTC, Daniel Hanscom (EUA, 1976).

Para o julgador, em razão dos preços supracompetitivos que a marca ReaLemon permitia a Borden Inc. praticar, as promoções realizadas pela empresa e os preços extremamente baixos por ela praticado de maneira não razoável em determinadas regiões forçavam os concorrentes a ou vender seus produtos a preços abaixo de seus custos ou a perder participação de mercado para a Borden. Em razão disso, entendeu que essas práticas representavam atos desleais de concorrência e, assim, ordenou que a Borden licenciasse gratuitamente a marca ReaLemon e seu desenho por um período de 10 anos para qualquer concorrente. Segundo o juiz da causa, "o elemento principal do poder de mercado mantido e preservado pela ré Borden reside na marca ReaLemon e sua posição de mercado dominante. Para que a concorrência entre no mercado de suco de limão processado, a barreira à entrada deve ser eliminada" (EUA, 1976).

Diante da ordem de licenciamento gratuito da marca, a Borden recorreu da decisão inicial. O FTC, em uma segunda decisão, adotou as mesmas conclusões factuais da decisão inicial, porém modificou os remédios anteriormente impostos. $\mathrm{O}$ licenciamento compulsório da marca ReaLemon não foi mais exigido. A maioria dos conselheiros entendeu que a proibição de praticar preços irrazoavelmente baixos já era suficiente para remediar o efeito anticoncorrencial da conduta da empresa sem ter que apelar para meios mais drásticos como o licenciamento compulsório (EUA, 1978).

Não satisfeita com a decisão do FTC, a Borden apresentou manifestação perante o Sexto Circuito da Corte de Apelação dos Estados Unidos, o qual confirmou, por maioria, a decisão do FTC (EUA, 1982b). 
De acordo com o Sexto Circuito, a Borden, Inc., de fato, tinha poder de mercado, o que era verificado, dentre outros fatores, pelo forte reconhecimento de sua marca, altos investimentos em publicidade, habilidade de praticar preços acima dos níveis competitivos em razão da forte preferência que os consumidores tinham pela marca ReaLemon. Em razão desse poder de mercado, tinha condições de praticar preços predatórios por períodos extensos em mercados geográficos específicos, o que tinha por efeito excluir concorrentes igualmente eficientes.

Com a entrada do republicano Ronald Regan no poder em 1981, todavia, a configuração do FTC mudou e diversos economistas seguidores da Escola de Chicago assumiram posições importantes. Assim, as ideias da Escola Estruturalista perderam forças.

Nesse cenário, foi aprovado um acordo no caso ReaLemon em que a Border se comprometeria a respeitar boas práticas de precificação (EUA, 1983).

O novo FTC criticou a visão adotada em seu parecer no caso em 1978, concluindo que a decisão não tinha balanceado adequadamente as vantagens competitivas da diferenciação do produto e a promoção da concorrência intermarcas pelo direito antitruste. Para o novo FTC, as marcas também exercem importantes funções pró-competitivas, em particular, a redução dos custos dos consumidores de tornarem-se informados sobre as vantagens e disponibilidade de uma marca.

O novo posicionamento do FTC resultou no arquivamento de outras duas representações ${ }^{26}$ que versavam sobre abuso de poder de monopólio via marcas.

No caso Cereals, o FTC tinha, em 1972, apresentado uma reclamação sob a alegação de que os quatro maiores produtores de cereais matinais mantinham um suposto "monopólio compartilhado" por meio da "proliferação de marcas", “diferenciação artificial de produtos similares" e "promoção de marcas por meio de ampla publicidade" (EUA, 1982a).

No caso Maxwell House, a General Foods Corp. foi originalmente acusada de promover "atividades promocionais excessivas" e "usar marcas de combate" para impedir a entrada relacionada à comercialização de Maxwell House Coffee (EUA, 1984a).

\footnotetext{
${ }^{26}$ Caso Cereals (EUA, 1982a) e Maxwell House (EUA, 1984a).
} 
O novo entendimento do FTC marcou a predominância das ideias da Escola de Chicago com relação ao instituto das marcas a partir da década de 80 e 90, e representou o arrefecimento das importantes considerações feitas pelos economistas adeptos do estruturalismo de Harvard. Mais recentemente, contudo, as lições da Escola Estruturalista voltaram a ser aceitas, sobretudo, a noção de barreiras à entrada associadas às marcas.

\subsubsection{Conclusões sobre as justificativas de proteção legal às marcas}

Embora tenha havido um embate teórico entre a Escola de Chicago e a Escola Estruturalista de Harvard no que tange aos pressupostos legais de proteção à marca e, ainda, aos seus efeitos, não se pode dizer que há uma vitória de uma teoria sobre a outra. Ambas trazem considerações relevantes acerca do instituto e suas implicações.

De um lado, não se pode negar que as marcas efetivamente reduzem os custos de busca do consumidor pelo produto que deseja consumir e que, para que elas mantenham sua função, as empresas devem manter constantes os atributos do produto, isto é, sua qualidade. Do contrário, perderiam vendas. Em razão disso, não se pode refutar que a proteção à marca gera algum nível de eficiência no mercado, conforme defendido pelos chicaguianos.

Por outro lado, é evidente que a marca não traz apenas um aspecto prócompetitivo. Enquanto instrumento de fidelização de consumidores e diferenciação de produtos, representa uma relevante barreira à entrada, conforme constatado pela Escola de Harvard, pois aumenta os custos irrecuperáveis dos entrantes, aumentando a probabilidade de exercício de poder de mercado pelos incumbentes. Ademais, conforme será tratado mais adiante, a marca é um fator determinante no exame da rivalidade entre as firmas. Em mercados de produtos diferenciados, a probabilidade de o poder de mercado ser exercido unilateralmente aumenta à medida que uma parcela significativa dos consumidores não desvia a demanda para produtos substitutos, tendo em vista suas fortes preferências por determinadas marcas.

No mais, é claro que a proteção à marca é importante para a proteção à reputação da empresa, na medida em que (a) permite o desenvolvimento das atividades 
empresariais apoiado em um instrumento de concorrência por diferenciação, aumentando, assim, as chances de a empresa fidelizar consumidores, ganhar mercados e construir uma história e reputação; e (b) impede que oportunistas se apropriem de ideias e produtos por elas concebidos e também de sua reputação, construída a partir desses elementos.

Também é patente que ela é relevante para a proteção do consumidor contra confusão, uma vez que impede a imitação, no todo ou em parte, do símbolo protegido.

Neste cenário, a análise concorrencial das marcas deve ter sempre em mente essas funções essenciais do instituto, que justificam sua proteção legal e são, em si, importantes para a manutenção de uma concorrência saudável entre as empresas.

Trata-se, em outras palavras, de reconhecer a racionalidade do direito de propriedade que assegura a existência do instituto e empreender uma análise antitruste cautelosa dos atos e condutas que envolvam esses direitos, sem que haja qualquer violação indevida a eles. Considerações sobre esses pontos serão feitas no Capítulo 2, a seguir. 


\section{CAPÍTULO 2. MARCAS - NOÇÕES DE PROPRIEDADE E SEUS CONDICIONANTES}

\subsection{Marca como propriedade e seus condicionantes}

A despeito de toda a dimensão concorrencial das marcas discutida no Capítulo 1, não se pode olvidar que a Constituição Federal atribuiu a elas o status de propriedade. ${ }^{27}$ Como propriedade, de um lado, há a garantia de um direito de exclusividade a seu titular, o que restringe, ao menos em tese, o espaço concorrencial em que se insere. Por outro lado, há uma série de restrições a esse mesmo direito, decorrente do próprio diploma constitucional e legal e também da dinâmica do Estado Social de Direito.

A razão do surgimento de direitos de propriedade sobre marcas e de sua proteção está ligada, conforme já discutido no capítulo anterior, a questões relacionadas à redução de search costs e assimetria de informação, ${ }^{28}$ possibilidade de efeito carona (free-riding) ${ }^{29}$ e apropriação indevida de reputação e esforços de terceiros e, ainda, à proteção do consumidor contra a confusão. Para Silveira (2011), foi conferido à marca esse status de bem imaterial exclusivo objeto de propriedade pela sua importância

\footnotetext{
${ }^{27} \mathrm{CF}$, art. $5^{\circ}$, inciso XXIX: "a lei assegurará (...) proteção à propriedade das marcas, aos nomes de empresas e a outros signos distintivos, tendo em vista o interesse social e o desenvolvimento tecnológico e econômico do país". Seguindo o mandamento constitucional, a legislação ordinária também atribui ao titular da marca um direito de exclusiva. Nesse sentido, dispõe o artigo 129 da Lei de Propriedade Industrial que "a propriedade da marca adquire-se pelo registro validamente expedido, (...) sendo assegurado ao titular seu uso exclusivo em todo o território nacional (...)".

${ }^{28}$ Conforme já mencionado anteriormente, os consumidores não têm informações completas sobre as características e qualidade do produto. Sem as marcas, os consumidores teriam que incorrer em altos custos de busca (searching costs) - que refletem custos de transação - a cada vez que desejassem consumir um produto, na medida em que não teriam informações sobre a origem do produto, tampouco a certeza de que ele apresenta características correspondentes a outro consumido anteriormente sob a mesma marca. A marca e sua proteção legal, portanto, permitem que os consumidores identifiquem adequadamente os produtos, que, em geral, seguem um padrão de qualidade.

${ }^{29}$ Sem qualquer proteção às marcas e, como consequência, sem qualquer sanção à imitação de conceitos e imagens associados ao produto de uma empresa ou à própria empresa, poderia haver a usurpação dos sinais distintivos por terceiros, causando perda de capital empresarial da primeira. A proteção à marca como direito de propriedade, nesse sentido, sinaliza que o sistema jurídico está protegendo os investimentos das empresas em sua reputação e construção de capital a longo prazo. Nesse sentido, explica Demsetz (1982) que a reputação de uma firma é um ativo tanto para ela quando para o comprador que confia nela porque informação não é de graça. Um sistema de direito de propriedade que garante proteção à patente, direito autoral e marca encoraja investimentos em 'permanência' e desencoraja operações transitórias e não confiáveis (fly-by-night operations).
} 
econômica, sua utilidade aos consumidores e pelo estímulo que representa à livre concorrência.

De fato, a proteção da propriedade das marcas é importante para manter a dinâmica do mercado, incentivando as empresas a concorrerem de maneira leal (sem reprodução indevida de marcas de terceiros e usurpação da reputação alheia) e com economias de custo de transação, e, ainda, redução dos custos de busca dos consumidores, protegendo-os contra a confusão.

Diante dessa perspectiva, pode-se dizer que a marca está intimamente ligada à defesa da livre iniciativa, ${ }^{30}$ à livre concorrência, à valorização do trabalho ${ }^{31}$ e à defesa do consumidor. Está, pois, em um sentido mais amplo, em consonância com a política econômica estatal de intervenção na economia com o propósito de garantir equilíbrio no mercado e, ao mesmo tempo, de incentivar as atividades dos agentes econômicos para fins de crescimento e desenvolvimento econômico.

Em outras palavras, o Estado intervém para garantir o status de propriedade à marca e, assim, possibilitar que os agentes tenham plenas condições de se diferenciar e concorrer de forma efetiva no mercado. Nesse sentido, explica Olavo (2005) que livre iniciativa conduz à existência de uma pluralidade de agentes econômicos atuando no mercado, e, portanto, à situação de concorrência. No contexto de um mercado competitivo, a propriedade intelectual (PI) protege a capacidade do empresário de inovar e de se distinguir, o que é uma vantagem nesse ambiente de concorrência.

Tanto a proteção à marca (enquanto propriedade) como a livre iniciativa, todavia, não são absolutas. Com a evolução das relações de produção e consumo e, ainda, a passagem do Estado Liberal, caracterizado pela intervenção estatal mínima e

\footnotetext{
${ }^{30}$ Embora concordemos com Eros Grau (1997) ao considerar a livre iniciativa como um conceito amplo que não se resume apenas à liberdade de empresa, sendo esta apenas uma de suas feições, tendo em vista o escopo do presente trabalho ao tratar de direito industrial e antitruste, naturalmente, a feição relativa à liberdade de iniciativa econômica, da qual a empresa é titular, será enfatizada.

${ }^{31}$ Em relação à proteção das marcas como forma de valorização ao trabalho, importante mencionar trecho da decisão do Tribunal Constitucional Alemão no caso "Schloßberg" (ALEMANHA, 1979): "Aquele que pode indicar através da marca características especiais de seus produtos empresariais não está, dessa forma, apenas denominando a origem de seu produto, mas antes, trata-se de expressão de sua vontade de trabalho. Corresponde ao sentido fundamental da propriedade proteger aquele que gera, dessa forma, um direito patrimonial. A função da garantia constitucional se resume exatamente nesse ponto, ou seja, garantir ao cidadão segurança jurídica em relação aos direitos patrimoniais reconhecidos pela ordem jurídica e proteger a confiança na preservação de seus direitos. Não seria compatível com o conteúdo jurídico dos direitos fundamentais se o Estado entendesse autorizada a revogação de uma marca sem compensação. Ele iria gerar exatamente o oposto da função de segurança jurídica, função para a qual a garantia da propriedade serve" (BARBOSA; GRAU-KUNTZ; BARBOSA, 2009, p. 60-61).
} 
alta valorização da propriedade, para o Estado Social de Direito, ${ }^{32}$ os direitos à propriedade passaram de uma visão de proteção absoluta para uma relativização das garantias a eles associadas, tendo em vista outros princípios da ordem econômica e, ainda, outros direitos que funcionam como condicionantes.

Com a marca, não poderia ser diferente. Seu "espaço de exclusão - a propriedade - é limitado por razões de concorrência e por razões constitucionais ao mínimo necessário para desempenhar adequadamente a função de diferenciação e de assinalamento (...)" (BARBOSA, 2005, p. 2). O exercício do direito de marca é, portanto, limitado por questões de defesa da concorrência, proteção ao consumidor, sem contar a própria função social que condiciona o exercício de qualquer direito de propriedade.

\subsection{Limites concorrenciais ao exercício do direito marcário}

2.2.1. Princípios da livre concorrência e da repressão ao abuso de poder econômico $\underline{\text { como elementos balizadores do direito de propriedade intelectual }}$

O exercício do direito sobre a marca (assim como qualquer outro direito de propriedade intelectual) encontra limites nos princípios da livre concorrência e de repressão ao abuso de poder econômico.

Esta ideia, todavia, nem sempre foi tão óbvia. Muito já se discutiu sobre se os direitos de propriedade industrial estariam isentos à aplicação do direito da concorrência. Conhecido e muito debatido é o posicionamento de Ascarelli (1970) em sua obra "Teoria da Concorrência e dos Bens Imateriais". Para esse autor, o Direito Concorrencial somente entraria em cena quando não houvesse regulamentação por parte do Direito Industrial. Trata-se, segundo Salomão Filho (2006), de uma visão clássica do Direito Industrial com uma vertente fortemente privatista.

\footnotetext{
32 Para um estudo detalhado sobre a evolução da concepção dos direitos de propriedade, vide Silva (2001), Del Nero (1997); e Comparato (COMPARATO, 1978).
} 
O entendimento que hoje prevalece seja na doutrina ${ }^{33}$ seja nos tribunais nacionais e internacionais, contudo, é o de que haveria uma intersecção ou interpenetração do Direito Concorrencial e do Direito Industrial. ${ }^{34}$ Nesse sentido, não se pode mais entender o Direito Industrial como uma matéria autônoma que pode se imiscuir da aplicação de regras gerais de ordem pública garantidoras da livre concorrência (MATHÉLY, 1976).

Neste contexto, a livre concorrência (art. 170, inc. IV) ${ }^{35}$ e a repressão ao abuso de poder econômico $\left(173, \S^{\circ}\right)$ consagram a noção de que outros direitos também deverão ser balizados por essas normas. Em sendo princípios gerais informadores da ordem econômica, não podem ser afastados na interpretação das práticas engendradas sob o manto da propriedade industrial.

Todos esses condicionantes são fundamentais no sistema econômico atual, caracterizado pela maior concentração econômica ${ }^{36}$ e maior capacidade dos agentes econômicos de manipularem variáveis de preço e quantidade para fins de aumentar lucros. Nesse contexto, estes princípios surgem como base jurídica para impedir que os agentes econômicos desvirtuem a livre iniciativa, prejudicando o bem estar social, e também como fundamento jurídico para a atuação do Estado na preservação do processo competitivo, impedindo e coibindo práticas nocivas à concorrência (RAGAZZO, 2006).

\footnotetext{
${ }^{33}$ Explicita Salomão Filho (2006, p. 132) que: “A complementaridade do direito industrial ao direito antitruste não é derrogatória. Pelas suas próprias origens recentes, de inspiração concorrencial, está e deve estar o direito industrial permeado pelos princípios concorrenciais. Antes que uma justificativa para a desaplicação do direito concorrencial, o direito industrial é um caso especial de sua aplicação". Da mesma forma, esclarece Grau-Kuntz (2007, p. 183): "Considerado dentro do sistema jurídico brasileiro o ordenamento não garantiu proteção à propriedade industrial como um valor em si mesmo, mas antes em função dos fins que cumpre, nomeadamente de fomentar a concorrência. Nesse sentido, a proteção aos bens imateriais só será justificada dentro de um quadro concorrencial".

${ }^{34}$ Salomão Filho (2006) defende que essa visão clássica não é capaz de fazer frente às exigências da sociedade contemporânea cujas necessidades de acesso a novas tecnologias, com baixo custo, são cada vez mais urgentes. Para ele, o Direito Concorrencial impõe uma revisão de conceitos, exigindo uma proteção da garantia institucional da concorrência mesmo no campo do Direito Industrial, o qual sofre uma reforma em decorrência direta dos princípios transformadores da organização do trabalho e da produção, introduzidos pela revolução industrial.

${ }^{35}$ De fato, ensina Ferraz Jr. (1989) que "a livre concorrência de que fala a atual Constituição como um dos princípios da ordem econômica (art. 170, IV) não é a do mercado concorrencial oitocentista de estrutura atomística e fluida, isto é, exigência estrita de pluralidade de agentes e influência isolada e dominadora de uns sobre os outros. Trata-se, modernamente, de um processo comportamental competitivo que admite gradações tanto de pluralidade quanto de fluidez (...)".

${ }^{36}$ Segundo Eros Grau, o ordenamento jurídico convive com a realidade fática do poder econômico (1997). No mesmo sentido, adverte Ferraz Jr. (1995) que uma vez que a Constituição trata de abuso do poder econômico, ela certamente pressupõe que o poder econômico, em si, é um fenômeno normal no processo de produção e circulação da riqueza.
} 
Assim, no campo do Direito da Concorrência, o uso da marca pode ser limitado tanto no âmbito do controle preventivo (i.e. análise de atos de concentração) quanto no controle repressivo de condutas (i.e. análise de infrações à ordem econômica).

No contexto do controle preventivo, o Estado, dentro dos limites de sua função de agente normativo e regulador da atividade econômica, não raro, impõe restrições à aprovação de atos de concentração que envolvem a transação sobre direitos marcários (e.g. alienação de marcas, licenciamento, não uso). Estes limites serão estudados de forma mais detalhada no Capítulo 3.

No controle repressivo de condutas, a legislação concorrencial é clara ao estabelecer que o ato de açambarcar ou impedir a exploração de direitos de propriedade industrial ou intelectual ou de tecnologia e o exercício ou exploração abusiva de direitos de propriedade industrial, intelectual, tecnologia ou marca podem configurar infração à ordem econômica (art. 36, incisos XIV e XIX, da Lei $n^{\circ}$. 12.529/2011). As condutas com potencial anticompetitivo envolvendo o uso de marca serão analisadas com maior grau de profundidade no Capítulo 4.

\subsubsection{Interpretação equilibrada entre direito da concorrência e os direitos intelectuais}

A análise casuística criteriosa é fundamental para a correta aplicação dos princípios da livre concorrência e da repressão ao abuso econômico ao exercício dos direitos intelectuais. Do contrário, corre-se o risco de se banalizar a propriedade intelectual, esvaziando-se todos os seus institutos. Por essa razão, as regras sobre a conceituação e prova do abuso nesses casos deverão ser rigorosas e restritas. ${ }^{37}$

Os direitos intelectuais têm função essencial no aprimoramento e incentivo à inovação e na proteção dos investimentos dos agentes econômicos com vistas à promoção do processo competitivo. O direito concorrencial, por sua vez, inibe

\footnotetext{
${ }^{37}$ Ao tratar especificamente das patentes, Bostyn e Petit (2013, p. 16-17) afirmam que “(...) not all patent strategies fall within the remit of EU competition law. As long as the dominant firm acts within the 'specific subject matter' (or seeks to maintain the 'essential function') of the patent, its conduct is presumably lawful. (...) This leaves only a marginal subset of patent strategies subject to antitrust exposure. (...) antitrust enforcement is only warranted in 'exceptional circumstances'. And such exceptions are to be interpreted strictly, to accord with the old maxim that "exceptions need to be interpreted restrictively, not expansively' (...)".
} 
condutas oportunistas que causem prejuízo ao mercado. ${ }^{38}$ As funções de um e outro direito são essencialmente complementares. ${ }^{39}$

A proteção ao direito de propriedade intelectual permite a construção de um ambiente institucional inovador que, segundo, os neo-schumpeterianos, é fruto de uma “atuação positiva do Estado, que é responsável por criar condições em estímulos que levem à inovação" (PFEIFFER, 2010, p. 102). Com isso, incentiva-se a concorrência dinâmica, que é fomentada pela inovação tecnológica, que causa a perturbação ou a revolução do estado estacionário do mercado, resultando no desenvolvimento (PFEIFFER, 2010).

Por esse motivo, não se pode fazer prevalecer um direito sobre outro. Propriedade intelectual e concorrência têm cada um uma função complementar e estão em níveis idênticos (NUNES et al., 2009). Nesse sentido, "a tendência de fazer predominar, mais ou menos sistematicamente, os princípios e os objetivos exclusivos do direito concorrencial leva ao desconhecimento da particularidade e da legitimidade dos direitos intelectuais" (BERCOVICI, 2013, p. 31) ${ }^{40}$.

Com efeito, não há no ordenamento brasileiro qualquer regra que permita a sobreposição da defesa da concorrência sobre os direitos intelectuais e vice-versa. Tanto os princípios da livre concorrência e da repressão ao abuso de poder econômico

\footnotetext{
${ }^{38}$ Sobre o papel da concorrência na interface com os direitos de propriedade intelectual, ressalta Ullrich (2004, p. 2) que: "Competition law thus responds to fears that private ordering might otherwise unduly encroach on what to remain a free resource for independent innovation or that it might transform the process of appropriating knowledge into actual control of markets. In doing so, competition law performs a critical but rather traditional role, one that concerns the much discussed interface between the protection of intellectual property laws, whose exclusive rights seem to confer legal monopolies and free intrabrand competition. The major goal here is to safeguard the incentive and reward rationales of intellectual while at the same time controlling the risks of an undue extension of legal exclusivity".

${ }^{39}$ De acordo com Chavanne e Burst, portanto, embora o direito concorrencial e o direito de propriedade industrial se utilizem de meios diversos, ambos têm o mesmo objetivo, isto é, a promoção de uma concorrência saudável entre os agentes do mercado. Sobre os diferentes instrumentos do direito da concorrência e do direito da propriedade intelectual, os autores entendem que: “(...) l'opposition qui peut exister entre les règles relatives aux droit de brevet et celles qui ont pour objet la préservation de la concurrence porte essentiellement sur les moyens mis en oeuvre pour amener les entreprises à pratiquer une saine concurrence, source de progrès economique. C'est la raison pour laquelle les régles positives actuelles du droit de la concurrence obligent à rechercher s'il peut exister un benéfice économique à certains comportements qui de prime abord paraissent restrictifs de concurrence. Le droit de la concurrence fait appel à des moyens répressifs car sa fonction est de sanctionner les pratiques anticoncurrentielles, alors que le droit des brevets fait appel à un système de stimulation. Nèamoins, en cas d'abus, son exercice est limité à la fois par le droit de proprieté intellectuelle et par les règles de concurrence. Le système des licences forcées en donne un bon exemple" (CHAVANNE; BURST, 2006).

${ }^{40}$ Para corroborar essa ideia, Bercovici cita os ensinamentos de Comparato (1995, p. 44): "Aliás, a consideração exclusiva dos aspectos concorrenciais, no regime das patentes, acarreta a negação prática de sua função social, de estímulo às invenções de interesse para a coletividade”.
} 
quanto os direitos intelectuais são constitucionalmente assegurados e devem ser compatibilizados para atingir seus objetivos.

Conforme já amplamente discutido pela doutrina especializada, a incorporação da livre concorrência como um princípio, posicionou-a como um instrumento de política econômica (i.e. uma politica pública) e não como um fim em si mesmo. Nessa linha, Forgioni (2014, p. 190) explica que “o antitruste já não é encarado apenas em sua função de eliminação dos efeitos destrutíveis do mercado, mas passa a ser considerado instrumento ou meio de que dispõe o Estado para conduzir e conformar o sistema" 41

Como qualquer política pública, portanto, defesa da concorrência é instrumental, parcial e limitada. Há relatividade e variabilidade na formulação e aplicação das suas regras, "a depender da concepção que, em cada momento, se tiver sobre os benefícios dessa competição" (OLAVO, 2005, p. 247). Dessa maneira, deve trabalhar em conjunto com outras políticas para atingir os objetivos mais gerais da política econômica. ${ }^{42}$ Disto decorre que a política concorrencial não pode substituir ou se sobrepor às demais políticas ou aos demais aspectos integrantes da política econômica. Ao contrário, deve com eles se harmonizar, sob pena de causar prejuízos à sociedade (BERCOVICI, 2013).

De fato, se mal aplicado, o direito antitruste pode ser prejudicial na medida em que coíba ou penalize a legítima exploração dos direitos de propriedade intelectual, protegendo agentes menos eficientes, que muitas vezes dependem da cópia ou imitação para concorrer no mercado (LILLA, 2014).

A defesa da concorrência não tem como objetivo a correção de falhas do sistema de direitos intelectuais nem de outros regimes regulatórios. Desse modo, não cabe às autoridades antitruste intervirem na exploração normal de direitos de propriedade intelectual (LILLA, 2014). Obviamente, definir os limites entre a

\footnotetext{
${ }^{41}$ Nesse sentido, Grau (1997) e Bercovici (2013).

${ }^{42}$ Nessa linha, afirma Prado (2011, p. 339) que: “(..) há hoje no país pouca relação e comunicação insuficiente entre as autoridades de defesa da concorrência e outros setores que atuam com politicas públicas que afetam a concorrência. Essa pouca coordenação se expressa na ausência de considerações concorrenciais para as negociações comerciais brasileiras, inclusive no que se refere a acordos tarifários. Há, ainda, insuficientes considerações sobre questões concorrenciais na política industrial brasileira e nos órgãos que a implementam, como o BNDES. Ou seja, qualquer formulação de uma política de defesa da concorrência para uma estratégia de desenvolvimento no Brasil tem como ponto de partida a busca de mecanismos para maior integração entre três dimensões da política pública: a política antitruste, a política industrial e a política de comércio exterior".
} 
exploração normal e legítima dos direitos de propriedade intelectual e sua exploração abusiva é uma questão com as quais as agências antitruste e tribunais têm se debatido (e digladiado) até hoje.

Interessante notar que, em casos envolvendo direitos constitucionalmente estabelecidos não ligados aos direito intelectuais, o CADE recentemente adotou uma interpretação mais rigorosa quanto à possibilidade de limitação desses direitos pela política antitruste. Em Sulpetro (BRASIL, 2014d), o Conselheiro Gilvandro Araújo entendeu que o direito constitucional da manifestação do pensamento e/ou direito à petição poderia ser restringido. No entanto, a caracterização de abuso concorrencial deveria ser pautada por critérios objetivos. Para o Conselheiro, "existem autonomias nos arcabouços jurídicos" de modo que não cabe ao CADE verificar se decisão do Executivo ou ato do Legislativo estão viciados, havendo, para tanto, leis e competências próprias. ${ }^{43}$ Este mesmo rigor deveria ser aplicado em casos envolvendo direitos intelectuais.

Neste contexto, e a fim de evitar a colisão da política pública de defesa da concorrência com os direitos intelectuais, Bercovici (2013) ressalta a necessidade de "rígidos padrões de prova" quando da eventual aplicação da legislação concorrencial em situações que envolvam a proteção de propriedade intelectual. Nessa linha, os fatores de prova deveriam ser analisados restritivamente.

Especialmente no caso das marcas, que são responsáveis por mover a sociedade de consumo atual e são fundamentais no processo competitivo das empresas, uma interpretação acrítica das condutas de seus titulares poderá acabar por esvaziar o instituto. Conforme afirma Barbosa (2002, p. 145), “entre a adequada função concorrencial da marca e seu abuso, há um espaço constitucionalmente delineado que a lei deve distinguir e implementar". Desse modo, um padrão elevado de prova deverá ser adotado em casos envolvendo o abuso do direito de marca como infração concorrencial para que exercício legítimo de um direito industrial não seja indevidamente mitigado.

\footnotetext{
${ }^{43} \mathrm{O}$ Conselheiro Gilvandro ressaltou que, relacionar a conduta ilícita na esfera concorrencial com base em elementos subjetivos de probabilidade ou plausibilidade não seria adequado, uma vez que "poderia suscitar (i) questões de prejudicialidade externa e (ii) ter o juízo do CADE contraposto por outra autoridade, mormente para quem foi dirigida a petição (...)". Assim, o critério objetivo a ser utilizado pela autoridade para aferir a ilicitude antitruste recairia sobre a aferição de falsidade nas manifestações sob análise. Este seria, então, o "elemento objetivo com potencial de trazer prejuízos à concorrência" (BRASIL, 2014d).
} 


\subsection{Proteção ao consumidor como condicionante ao uso da marca}

O exercício do direito sobre a marca também está limitado pelo direito à informação do consumidor assim como pelas normas relacionadas à oferta e à publicidade de produtos e serviços no mercado de consumo (MIRAGEM, 2014). Nessa linha, o CDC estabelece no seu art. $4^{\circ}$, inciso VI, que a Política Nacional de Relações de Consumo está pautada pelo principio da "coibição e repressão eficientes de todos os abusos praticados no mercado de consumo, inclusive a concorrência desleal e utilização indevida de inventos e criações industriais, das marcas e nomes comerciais e signos distintivos, que possam causar prejuízos aos consumidores." 44

Como ensina Pfeiffer (2010), a distribuição assimétrica de informações é um dos elementos que acentuam a vulnerabilidade do consumidor. Por essa razão, o direito à informação adequada é um dos direitos mais importantes dos consumidores. Trata-se, ainda, de um fator com maior impacto na esfera concorrencial, na medida em que a informação prestada no momento pré-contratual é decisiva na escolha do consumidor pela aquisição do produto. Desse modo, há uma preocupação da legislação consumerista em impedir que informações incorretas, não adequadas ou enganosas sejam transmitidas em uma relação de consumo.

Pela sistemática do $\mathrm{CDC}$, o consumidor tem direito à "informação adequada e clara sobre os diferentes produtos e serviços, com especificação correta de quantidade, características, composição, qualidade, tributos incidentes e preço, bem como sobre os riscos que apresentem" (art. $6^{\circ}$, III, do CDC).

Nesse sentido, o dever de informação do fornecedor passa a ser obrigação fundamental para a harmonia e transparência das relações de consumo, que deve orientar tanto a embalagem e apresentação do produto, como sua veiculação

\footnotetext{
${ }^{44}$ Nesse sentido, aponta Soares (2003, p. 631-632) que: “A política visa (...) impedir, tolher e/ou proibir e também reprimir, sustar, castigar e punir todos os abusos praticados no consumo e estes em boa maioria são os atos de concorrência desleal e muitas vezes desenfreada, praticados pelo uso indevido de sinais distintivos através das figuras da reprodução e da imitação de marcas que se encontram no mercado consumidor, aproveitando dos seus elementos verbais, numéricos, nos dísticos, emblemas, desenhos, envoltórios, invólucros e bem assim nos característicos que envolvem a apresentação de um produto ao mercado com ou sem aplicação e/ou disposição de cores. Estes sinais distintivos, como acima vistos genericamente, quando utilizados de maneira indevida por terceiros é que causam prejuízos aos consumidores. Por assim se apresentarem, sob vestimentas iguais ou semelhantes com ainda a agravante de conterem quase sempre seus preços inferiores, são facilmente adquiridos e/ou consumidos como se fossem verdadeiros".
} 
(oferta) por meio da publicidade (MARQUES, 1999). Essa é a dicção do art. 31 do CDC.

O dever de informar é essencial para que o consumidor possa ter informações claras e objetivas sobre o produto, de forma a poder compará-lo com outros, tomando uma decisão de compra consciente. Nessa linha, deve a marca, seja enquanto manifestação do produto, seja enquanto instrumento de publicidade, possibilitar que o consumidor tenha plena capacidade de distingui-la de outras, garantindo-se, assim, a sua liberdade de escolha.

Este dever de informação, que "é contínuo, incidindo em todas as fases da relação de consumo" (PFEIFFER, 2010, p. 67) está intimamente ligado à proteção do consumidor contra atos confusórios ${ }^{45}$ do titular da marca ou fornecedor, que representa, ao mesmo tempo, uma das razões de ser da marca, mas também um de seus condicionantes. Se a apropriação de marcas de terceiros fosse permitida, a função distintiva e identificadora do instituto se esvaziaria (OLAVO, 2005) e, assim, o papel da marca na proteção da reputação de seu titular. A confiança do consumidor no produto, que orienta sua decisão de compra e constitui a base fundamental das relações de consumo, seria perdida e o titular da marca perderia vendas.

Por este motivo, a tutela do consumidor contra a confusão é um elemento central na análise de casos envolvendo o uso indevido de marcas. A jurisprudência brasileira, inclusive, tende a conferir uma proteção ampla ao consumidor nesses casos, utilizando o conceito do "consumidor desatento".

Com relação a este conceito, sustentou a Min. Nancy Andrighi, em seu voto em Unilever v. Bio Brilho (BRASIL, 2007b), que:

"em nenhum momento a Lei exige que a semelhança entre as marcas seja grande a ponto de confundir até mesmo o observador atento. Para a Lei basta que os produtos sejam parecidos a ponto de gerar confusão (...) A Lei se destina não ao consumidor atento, mas justamente ao consumidor que, por qualquer motivo, não se encontra em condições de diferenciar os produtos similares. Não se pode descurar do fato de que, muitas vezes, o consumidor não pode ler a embalagem de um produto ou, ao menos, tem dificuldade de fazê-lo, seja por seu grau de

\footnotetext{
${ }^{45}$ Dias (2013, p. 294) ensina que "os atos de confusão, que se manifestam tanto na oferta e apresentação de produtos quanto na publicidade, são conhecidos na doutrina inglesa por 'passing off' e se traduzem no ato fraudulento de passar mercadoria própria como alheia".
} 
instrução, por problemas de saúde ocular ou mesmo por pressa. Nesses casos, tudo o que o consumidor distinguirá será a forma da embalagem, as características gerais do produto, as cores apresentadas e assim por diante. ${ }^{46}$

Além de utilizar-se de um conceito bastante protetivo do ponto de vista do consumidor, há decisões judiciais que sequer exigem que a confusão tenha efetivamente ocorrido, bastando a mera "possibilidade de confusão". ${ }^{47}$

As decisões revelam, portanto, um forte viés pró-consumidor e são indicativas do papel primordial da adequada informação do consumidor para o regular funcionamento do sistema marcário.

Em se tratando especificamente da publicidade da marca, além do dever de informação, cabe mencionar a necessidade de obediência ao princípio da transparência ou veracidade, que, segundo, Pfeiffer (2010, p. 70), representa "pedra angular na disciplina da publicidade no âmbito do CDC”. Este princípio decorre da boafé objetiva e consiste na garantia de adequação à função informativa da publicidade (DIAS, 2013). Nessa linha, o fornecedor deve garantir a informação prestada e também o cumprimento da oferta veiculada.

Nesse sentido, aponta Marques (1999, p. 328) que "o CDC regula a publicidade, enquanto meio de informação ao consumidor para lhe vincular alguns dos efeitos nos arts. 30, 31, 35, 36, 37 e 38 ".

\footnotetext{
${ }^{46}$ Para Miragem (2014, p. 92), a definição de quem seja o consumidor desatento perpassa pela análise da vulnerabilidade do agente. Dessa maneira, deverão ser examinados elementos como "espécie e destinação do produto, público-alvo, modo de comercialização e outras condições".

${ }^{47}$ Em Koch Advogados Associados vs. Koch e Koch Advogados e Consultores (BRASIL, 2008d), o STJ posicionou-se no sentido de que: "(...) a semelhança da marca "Koch" e do nome da requerida, "Koch \&Koch", é evidente. Da mera semelhança, extrai-se, logicamente sem quaisquer elementos probatórios adicionais, a possibilidade de confusão. Quem já conhece pessoalmente os prestadores de serviços, talvez possa bem diferenciar a advocacia "Koch" da"Koch \&Koch". Por outro lado, quem apenas ouviu dizer do serviços de um e outro, sem um conhecimento prévio, não saberá distinguir as partes litigantes. Assim, a potencialidade de confusão está justamente nos clientes ainda não conquistados. Este potencial para o engano basta para configurar violação direto de marca. Em termos penais, o art. 189, Lei 9.279/96, toma como "crime contra o registro de marca" a conduta de quem "reproduz, sem autorização do titular, no todo ou em parte, marca registrada, ou imita-a de modo que possa induzir confusão" (g.n) Ora, se a mera possibilidade é suficiente para fins criminais, deve-se reconhecer que ela também o será para fins civis. Daí ser irrelevante a conclusão a qual chegam a sentença e o acórdão recorrido, que julgaram improcedente os pedidos por não haver prova da confusão." No mesmo sentido, em Ricavel vs. Ricave (BRASIL, 2009c), o STJ entendeu que "para a tutela da marca basta a possibilidade de confusão, não se exigindo prova de efetivo engano por parte de clientes ou consumidores específicos". Para decisões contrárias, que exigem demonstração da hipótese de confusão, desvio de clientela e/ou concorrência desleal, vide Miragem (2014).
} 
Desse modo, caso eventual promessa feita durante a veiculação da publicidade do produto ou serviço não seja cumprida, poderá o consumidor exigir o seu cumprimento, nos termos do art. 35 , inc. I, do CDC.

O artigo 36, por sua vez, traduz o princípio da identificação obrigatória da mensagem, que tem como objetivo cientificar o consumidor de que ele é alvo de uma mensagem publicitária de modo a não induzi-lo a erro.

Particularmente importante, no contexto do princípio da veracidade, é a repressão à publicidade enganosa. O CDC proíbe "qualquer modalidade de informação ou comunicação de caráter publicitário, inteira ou parcialmente falsa, ou, por qualquer outro modo, mesmo por omissão, capaz de induzir em erro o consumidor a respeito da natureza, características, qualidade, quantidade, propriedades, origem, preço e quaisquer outros dados sobre produtos e serviços" (art. 37, § $1^{\circ}$ ).

Há, ainda, preocupação com a publicidade comparativa. Especialmente quando ela tenha conteúdo denigritório, a jurisprudência brasileira tem considerado o seu caráter abusivo. Decisão recente do STJ em Nesvita v. Activia (BRASIL, 2014g) reconhece que a publicidade comparativa não é ilegal a priori. Segundo o Ministro Relator Luis Felipe Salomão a publicidade comparativa não é vedada pelo Código de Defesa do Consumidor (CDC), desde que obedeça ao princípio da veracidade das informações, seja objetiva e não abusiva. Ressaltou que, para que a propaganda comparativa infrinja o direito marcário do concorrente, "as marcas devem ser passíveis de confusão ou a referência da marca deve estar cumulada com ato depreciativo da imagem de seu produto/serviço, acarretando a degenerescência e o consequente desvio da clientela". Do contrário, a livre iniciativa e a livre concorrência seriam impedidas, restringindo de forma desmedida a atividade econômica e publicitária. Ademais, segundo ele, "implicaria retirar do consumidor maior acesso às informações referentes aos produtos comercializados e a poderoso instrumento decisório" (BRASIL, 2014g).

Diante deste cenário, está claro que o dever de informação e o princípio da transparência/veracidade imprimem ao uso da marca obrigações fundamentais seja para a defesa do consumidor, seja para a própria manutenção e sobrevivência do instituto marcário. Com uma oferta e apresentação clara e adequada da marca, evita-se que as legítimas expectativas e a confiança dos consumidores sejam frustradas e 
garante-se a permanência da marca como elemento central das relações de consumo na sociedade contemporânea. ${ }^{48}$

\subsection{Limites inerentes à função social da propriedade}

Por fim, a marca, por ser um direito sobre propriedade, também está limitada pela sua função social, nos termos do art. $5^{\circ}$, inciso XXIII, e art. 170, inc. III da Constituição Federal. No caso específico dos direitos de propriedade industrial, particular relevância tem o art. $5^{\circ}$, inc. XXIX da Constituição Federal:

“a lei assegurará aos autores de inventos industriais privilégio temporário para sua utilização, bem como proteção às criações industriais, à propriedade das marcas, aos nomes de empresas e a outros signos distintivos, tendo em vista o interesse social $e$ o desenvolvimento tecnológico e econômico do País".

Adianta-se, todavia, que, na doutrina, são escassos os estudos sobre a função social das marcas, instituto que se aborda no presente trabalho.

\subsubsection{Noções gerais sobre a função social da propriedade}

A ideia de função social da propriedade apareceu, pela primeira vez, na Constituição de Weimar de 1919 (COMPARATO, 1996). Estabelecia seu artigo 135 que "A propriedade obriga. Seu uso deve igualmente ser um serviço ao bem comum". 49

\footnotetext{
${ }^{48}$ Nesse sentido, aponta Pfeiffer (2010, p. 71-72) que: "Uma questão interessante e que dá margem a grande impacto concorrencial é a reputação das marcas, vantagem competitiva usufruída sobretudo por empresas multinacionais de grande porte, que leva o consumidor a ter mais confiança na sua qualidade e na facilidade de reparação do produto por vícios que apresentar, em especial durante o período de garantia. A reputação da marca incute no consumidor maior confiança no produto e na possibilidade de melhor exercer os direitos correlatos, sendo uma barreira a ser superada pelos demais concorrentes. Evidentemente que tal aspecto não é deletério, muito menos ilícito. Muito pelo contrário, é um atributo da empresa conquistado com grande esmero e investimento, inclusive em publicidade. Nesse contexto, a reputação angariada com o bom desempenho da empresa e em publicidade é algo absolutamente natural no processo competitivo, sendo um dos traços marcantes do sistema capitalista. No entanto, se é saudável que a empresa invista em publicidade para fixar a sua marca e com isso angariar a preferência dos consumidores, é deletério (e ilícito) que ela o faça através da publicidade enganosa. Através de tal expediente o consumidor é levado a erro (já que identifica equivocadamente um atributo que a empresa não possui) e os concorrentes que eticamente se recusam a enganar o consumidor são prejudicados, pois perdem clientes para a empresa que praticou a enganosidade".
} 
No Brasil, obteve status constitucional desde a Constituição de 1934, passando pela de 1937, 1946, 1967-1969 e 1988 (DEL NERO, 1997).

Atualmente, a função social da propriedade está insculpida no artigo $5^{\circ}$, inciso XXIII ${ }^{50}$, e também no artigo 170, inciso III $^{51}$, da Constituição Federal de 1988, além de referências indiretas em outros dispositivos esparsos.

Para Silva (2001, p. 792), a importância desse princípio é posicionar a propriedade como "um dos instrumentos destinados à realização da existência digna de todos e da justiça social".

De acordo com Grau (1997), a função social da propriedade representa um poder-dever, na medida em que condiciona o poder a uma finalidade.

De fato, afirma Comparato (1986, p. 75) que ela significa "o poder de dar ao objeto da propriedade destino determinado, de vinculá-lo a certo objetivo". Esse objetivo, por sua vez, é social, isto é, não está ligado a um direito de cunho individualista do titular da propriedade. Antes, corresponde a um interesse coletivo e, nesse sentido, impõe um poder-dever ao proprietário, o qual é passível de sanção pela ordem jurídica.

Seguindo a ideia de que a propriedade deve estar atrelada a certa finalidade social, será discutido no próximo item qual seria ela para o caso específico da propriedade industrial.

\subsubsection{Função social da propriedade industrial: histórico}

Uma semente do princípio da função social aplicado à propriedade intelectual pode ser encontrada no Alvará de 28 de abril de 1809 (ZAITZ; ARRUDA, 2008 , p. 39) especificamente em relação aos inventos industriais e artísticos. Esta normativa assim dispunha em seu inciso sexto:

\footnotetext{
49 Versão original em alemão: "Eigentum verpflichtet. Sein Gebrauch soll augleich dem Wohle der Allegemeinheit dienen".

50 “A propriedade atenderá a sua função social”.

51 “Art. 170. A ordem econômica, fundada na valorização do trabalho humano e na livre iniciativa, tem por fim assegurar a todos existência digna, conforme os ditames da justiça social, observados os seguintes princípios: (...) III - função social da propriedade".
} 
"VI. Sendo muito conveniente que os inventores e introdutores de alguma nova máquina e invenção nas artes gozem do privilégio exclusivo, além do direito que possam ter ao favor pecuniário, que sou servido estabelecer em benefício da indústria e das artes, ordeno que todas as pessoas que estiverem neste caso apresentem o plano de seu novo invento à Real Junta do Comércio; e que esta, reconhecendo-lhe a verdade e fundamento dele, lhes conceda o privilégio exclusivo por quatorze anos, ficando obrigadas a fabricar depois, para que, no fim desse prazo, toda a Nação goze do fruto dessa invenção. Ordeno, outrossim, que se faça uma exata revisão dos que se acham atualmente concedidos, fazendo-se público na forma acima determinada e revogando-se todas as que por falsa alegação ou sem bem fundadas razões obtiverem semelhantes concessões" (g.n.).

Referido Alvará estabelecia a obrigação de fabricação do invento durante o período do privilégio para que, findo esse limite temporal, toda a Nação pudesse gozar do fruto da invenção. Tal declaração reflete, naquela época, uma preocupação com o interesse nacional frente ao interesse individual do inventor. É certo que o privilegiava individualmente com a exclusividade, haja vista o interesse em remunerar os investimentos do agente no desenvolvimento da invenção e não impunha nenhuma condicionante específica ao exercício do direito. No entanto, para a época, a incorporação dos interesses da Nação na normativa já representa uma fagulha de interesse público em um contexto onde o que prevalecia era o individual.

$\mathrm{Na}$ realidade, toda a regulamentação da propriedade intelectual até o período imediatamente anterior à Constituição de 1988 foi marcada essencialmente pelo viés predominantemente privatista.

Nesse sentido, a Constituição Imperial de 1824, apesar de prever uma exceção ao pleno exercício do direito da propriedade ${ }^{52}$, no que diz respeito especificamente à propriedade industrial, não trazia qualquer restrição à concessão ou manutenção do privilégio, limitando-se a estipular, em seu artigo 179, inciso XXVI, que “os inventores terão a propriedade de suas descobertas ou de suas produções. A lei lhes

\footnotetext{
${ }^{52}$ Artigo 179, inciso XXII: "Se o bem público legalmente verificado exigir o uso e emprego da propriedade do cidadão, ele será previamente indenizado do valor dela. A lei marcará os casos em que terá lugar essa única exceção e dará as regras para se determinar a indenização".
} 
assegurará um privilégio exclusivo temporário, ou lhes remunerará em ressarcimento de perda que hajam de sofrer pela vulgarização".

Aqui também o aspecto temporário da exclusividade beneficia o inventor e pretende representar uma contrapartida por sua invenção. Ao mesmo tempo, tendo em vista a limitação temporal e a incorporação da tecnologia durante a vigência da exclusiva, a sociedade é beneficiada, posteriormente, com a possibilidade de que outros agentes entrem nesse mercado antes privilegiado. Ademais, há referência à vulgarização do invento, o que, entende-se, representa uma mitigação da exclusividade. Conforme se nota, há uma preocupação em remunerar o inventor por esse fato.

A regulamentação do instituto da patente pela legislação ordinária deu um tom mais publicista ao instituto. De fato, a Lei $\mathrm{n}^{\mathrm{o}}$. 3.129, de 14 de outubro de 1882, vigente durante a Constituição Imperial, estabelecia, em seu artigo $1^{\circ}, \S 4^{\circ}$, que, se durante o prazo de vigência da patente, a "necessidade" ou "utilidade pública" exigisse a vulgarização da invenção, poderia haver a desapropriação, mediante as formalidades legais ${ }^{53}$.

O tratamento dispensado à propriedade industrial não sofreu modificações com a entrada em vigor da primeira Constituição Federal de 1891. Nessa época, ainda não havia se iniciado o movimento intervencionista de cunho socialdemocrata. Ainda vigoravam as ideias de propriedade absoluta, contratualismo e pacta sunt servanda e laissez-faire (CERQUEIRA, 2006).

Com a promulgação da primeira Constituição social no Brasil, em 1934, o interesse social ou coletivo ganha maior destaque e não só a propriedade tradicional é sujeita a ele como também as patentes. Nesse sentido, previa o artigo 113, item 18, desse diploma que "os inventos industriais pertencerão a seus autores, aos quais a lei garantirá privilégio temporário, ou concederá justo prêmio, quando a sua vulgarização convenha à coletividade" (g.n.).

É a primeira vez, portanto, que a propriedade industrial, mais especificamente, o instituto das patentes, é sujeita a um condicionante social em nível constitucional.

\footnotetext{
${ }^{53}$ Art. $1^{\text {o: }}$ "A lei garante pela concessão de uma patente ao autor de qualquer invenção ou descoberta e sua propriedade e uso exclusivo. (...) $\$ 4^{\circ} \mathrm{O}$ privilégio exclusivo da invenção principal só vigorará até 15 anos, e o do melhoramento da invenção concedido ao seu autor, terminará ao mesmo tempo que aquele. Se durante o privilégio, a necessidade ou utilidade pública exigir a vulgarização da invenção, ou o seu uso exclusivo pelo Estado, poderá ser desapropriada a patente, mediante as formalidades legais”.
} 
Em 1937, no entanto, a proteção às patentes deixou de ter o status constitucional. Essa situação perdurou por curto tempo, já que a Constituição Federal de 1946 repetiu $^{54}$, no que tange os inventos industriais, o dispositivo da Constituição Federal de 1934.

Em relação às Constituições Federais da época ditatorial - 1967 e 1969, estas asseguravam o direito de propriedade, salvo o caso de desapropriação por necessidade ou utilidade pública ou interesse $\operatorname{social}^{55}$, e, ainda, garantiam o privilégio temporário aos autores de inventos industriais bem como a exclusividade das marcas de indústria e comércio ${ }^{56}$. Não havia, desse modo, condicionantes específicos à propriedade industrial em nível constitucional, apenas à propriedade em geral, que usualmente, era interpretada como aquela relacionada aos bens materiais. Dessa maneira, a possibilidade de desapropriação por necessidade ou utilidade pública ou interesse social não tinha aplicabilidade efetiva em relação a marcas e patentes.

Importante mencionar que, nessa época, como o Brasil passava por uma fase de substituição das importações, verificava-se uma grande preocupação com que a concessão da patente estivesse vinculada à efetiva e regular utilização da invenção (SOARES, 1974).

As menções (quando existentes) ao interesse coletivo ocorreram exclusivamente em relação às patentes e não à propriedade industrial como um todo. Como se pode verificar da análise da evolução histórica da função social da propriedade industrial, não há qualquer menção ao interesse coletivo relacionado às marcas até as Constituições ditatoriais.

Foi apenas na Constituição Federal de 1988 que uma condicionante à propriedade industrial, incluindo patentes e marcas, aparece pela primeira vez no art. $5^{\circ}$, inc. XXIX.

Com isso, abandonou-se a visão excessivamente privatista da matéria a qual dava ao titular do direito de propriedade industrial poderes amplíssimos e irrestritos (FORGIONI, 2008). A propriedade intelectual, na visão de Barbosa (2002, p. 20 ), tornou-se "ainda mais funcional, ainda mais condicionada, ainda mais socialmente

\footnotetext{
${ }^{54}$ Artigo 141, § 17: "Os inventos industriais pertencem a seus autores, aos quais a lei garantirá privilégio temporário, ou, se a vulgarização convier à coletividade, concederá justo prêmio".

${ }_{55}$ Artigo 150, § 22, da Constituição de 1967, e artigo 153, § 22, da Constituição Federal de 1969.

${ }^{56}$ Artigo 150, § 24, da Constituição de 1967, e artigo 153, § 24, da Constituição Federal de 1969.
} 
responsável, e seguramente muito menos plena do que qualquer outra forma de propriedade".

Nessa linha, o CADE reconhece o caráter instrumental dos direitos de propriedade intelectual, que para além de satisfazer os interesses egoísticos de seus titulares, têm também de atender ao interesse coletivo. Esse foi o entendimento do Conselho no caso das Autopeças (BRASIL, 2010a, p. 23):

"Os próprios dispositivos constitucionais e infraconstitucionais que
instituem a proteção da propriedade industrial preveem que o
privilégio temporário sobre os inventos deverá ter em vista,
preponderantemente, o interesse social e econômico, (...) portanto, os
direitos de propriedade industrial são instrumentais, na medida em que
têm como beneficiário final o interesse coletivo. É claro que, ao
conceder exclusividade temporária ao autor do invento, o direito de
propriedade industrial visa permitir que o titular privado se aproprie
de sua criação e compense os esforços e riscos por ele empreendido.
Essa apropriação, contudo, é um instrumento privado de alcance, ao
final, de um interesse coletivo. (...) Esse é o fim precípuo dos direitos
de propriedade industrial, que, se desvirtuado, caracteriza a sua
abusividade".

A interpretação do artigo $5^{\circ}$, inciso, XXIX, da Constituição é tratada de duas formas pela doutrina. Em uma primeira hipótese, ele é entendido segundo um viés mais individualista, justificando a existência do privilégio em razão de sua proteção necessariamente atender ao interesse social e proporcionar o desenvolvimento tecnológico e econômico do país.

De acordo com Cerqueira (2006, p. 41-42):

“A razão de ser desse posicionamento encontra fundamento na evidência histórica de que as sociedades cujos regimes econômicos estiveram assentados no Princípio da Liberdade de Empresa e souberam premiar a criatividade dos agentes inovadores, puderam alcançar, ao fim e ao cabo, níveis satisfatórios e ascendentes de desenvolvimento tecnológico e econômico. O que, inicialmente, representava um benefício dirigido apenas ao indivíduo criador, espraiou-se em vantagens para toda a coletividade. (...) Nesse sentido, 
pode-se afirmar que o privilégio temporário concedido ao inventor atende ao interesse social"

Na segunda hipótese, defendida neste trabalho, a proteção só deve ser mantida na medida em que atenda ao interesse social e ao desenvolvimento tecnológico e econômico do país (ZAITZ; ARRUDA, 2008). ${ }^{57}$

De fato, ao analisar o dispositivo constitucional, Barbosa (2002, p. 24) conclui que “(...) na análise dessa cláusula, ressalta dela a vinculação dos direitos de propriedade ao compromisso geral com o uso social da propriedade - num liame teleológico destinado a perpassar todo o texto constitucional”.

\subsubsection{Função social da propriedade industrial: a questão específica da marca}

Com o advento da Constituição Federal de 1988 e do CDC em 1990, verificou-se que, assim como com relação aos demais direitos de propriedade industrial, recaia também sobre a marca a exigência de efetivamente atender a um fím social. A tutela do consumidor no mercado de consumo exigia também um direito de propriedade sobre marcas mais dialógico para evitar "os abusos praticados no mercado de consumo" (BARCELLOS, 2007, p. 63). ${ }^{58}$

Pode-se dizer que o regime real dos direitos sobre a marca envolve enorme interesse público em virtude de sua relação direta com a livre concorrência e com o direito do consumidor e dos impactos que podem causar sobre o mercado, o consumo e o consumidor (BARBOSA, 2011, p. 12).

Embora, conforme se tenha examinado no Capítulo 1, as marcas tenham ligação com a promoção da inovação, sua finalidade imediata está em uma etapa

\footnotetext{
${ }^{57}$ Este é também o entendimento de Rosenberg (2008, p. 175), para a qual "a proteção à propriedade industrial somente se justifica, pelo próprio texto constitucional, pelo incentivo ao "desenvolvimento tecnológico e econômico do país' (...)". Para a autora, a ideia de desenvolvimento tecnológico e econômico deve ser entendida como incentivo à inovação.

${ }^{58}$ Segundo Barcellos (2007), isso não significava que há mais de duas décadas não houvesse uma preocupação legal com os abusos praticados contra e pelos titulares de direitos marcários, mas sim que a repressão a estes abusos visava muito mais satisfazer os interesses ou solucionar conflitos entre concorrentes do que atingir um interesse social ou preocupar-se com os prejuízos que tais abusos pudessem gerar ao próprio consumidor.
} 
anterior de manutenção do próprio processo competitivo. ${ }^{59}$ Não por outra razão, a disciplina dos sinais distintivos (marcas, sinais de propaganda, insígnia, título de estabelecimento) tem "perfil concorrencial” (SILVEIRA, 2011, p. 101).

Esse perfil concorrencial foi reconhecido pelo STF. O Tribunal, em $P G R$ vs. Governador do Estado do Rio de Janeiro e ALERJ (BRASIL, 1988), ao comentar sobre o artigo da Constituição Federal de 1967 que dispunha sobre a garantia legal da propriedade das marcas de indústria e comércio ${ }^{60}$, entendeu que o dispositivo "assegura a disciplina do direito concorrencial" e que "o uso do nome ou dos sinais distintivos de determinado estabelecimento, em objetos oferecidos à comodidade da clientela, só poderá ser coibido se for identificada a sua finalidade ilícita, isto é, quando desborda os limites da concorrência".

A garantia de um processo competitivo saudável, por meio da adequada promoção das marcas e da repressão aos atos confusórios, denigritórios e de concorrência desleal, é fundamental para criar condições para o desenvolvimento econômico e tecnológico, e a própria inovação, em linha com a função estipulada pela Constituição Federal aos direitos de propriedade industrial (art. $5^{\circ}$, inc. XXIX). ${ }^{61}$

Sem a proteção à marca, as atividades de free riders estariam sendo desempenhadas sem qualquer freio, prejudicando a função diferenciadora da marca, a atividade empresarial ${ }^{62}$ (na medida em que a reputação de empresas que levaram anos ou mesmo décadas - de trabalho e esforços para construir uma marca com aceitação

\footnotetext{
${ }^{59}$ Ao discorrer sobre a finalidade da proteção às marcas, explicita o Tribunal Constitucional Alemão no caso "Schloßberg" que: "A preocupação da marca, ao contrário, se apoia em outras considerações. Nos limites de uma liberdade de indústria ilimitada a marca deve servir à configuração transparente do trabalho empresarial e, com isso, gerar um efeito balanceado na concorrência. Na marca é, às custas da livre concorrência, monopolizado um valor comercial que, (por sua vez), é reconhecido ao titular para sua exploração exclusiva. A razão de proteção encontra-se prioritariamente na simplificação do exercício comercial na concorrência. A marca não subscreve ao seu titular apenas a disposição exclusiva do sinal, mas é - considerando sua função - um instrumento importante para a existência e manutenção de seu capital empresarial".

${ }^{60}$ Art. 150, § 24, da Constituição Federal de 1967: "A lei garantirá aos autores de inventos industriais privilégio temporário para sua utilização e assegurará a propriedade das marcas de indústria e comércio, bem como a exclusividade do nome comercial".

${ }^{61}$ Aqui adota-se a premissa ressaltada por Ragazzo de que “(...) a economia de mercado com a garantia da livre concorrência é a melhor forma de maximizar o bem-estar social (...). A concorrência aumenta a eficiência alocativa, a eficiência produtiva e a capacidade de inovação dos mercados" (2006, p. 85).

${ }^{62}$ Nesse sentido, ensina Olavo (2005, p. 75) que "a proteção do poder atrativo das marcas reconduz-se, pois, em primeira linha, às regras que visam proteger a atividade de determinado empresário, a qual é (...) concretizada através da marca".
} 
perante o público seria destruída ${ }^{63}$ ) e, por consequência, a dinâmica da sociedade de consumo.

A finalidade das marcas, portanto, está em diretamente instrumentalizar o processo competitivo, garantir a proteção e continuidade dos investimentos em produtos e serviços, e, assim, criar condições para o desenvolvimento tecnológico e econômico do país.

Com efeito, a própria legislação marcária apresenta uma série de regras que visam à concretização desse viés pró-concorrencial do instituto. Dentre as mais relevantes dessas regras estão aquelas relacionadas (a) à especialidade, (b) à afinidade, (c) ao extravasamento do símbolo (ultraespecialidade), (d) à disciplina das marcas não registráveis e (e) à proteção contra concorrência desleal.

2.4.4. Legislação marcária: regras que dão concretude à função concorrencial das $\underline{\text { marcas }}$

(i) Princípio da especialidade

A especialidade está dentre os princípios basilares do sistema marcário. Segundo Barbosa (2008, p. 197), este princípio informa que "a exclusividade de um signo se esgota nas fronteiras do gênero de atividades que ele designa". Não por outra razão, o art. 123, inc. I, da LPI designa como marca de produto ou serviço "aquela usada para distinguir o produto ou serviço de outro idêntico, semelhante ou afim, de origem diversa".

Uma vez que a propriedade das marcas se exerce na concorrência, a especialidade atribui ao direito marcário uma função econômica bem delimitada. A marca somente deverá ter capacidade distintiva e será utilizada de forma exclusiva dentro de uma determinada categoria de produtos ou serviços a fim de cumprir com o

\footnotetext{
${ }^{63}$ A dupla finalidade das marcas na proteção ao consumidor contra atos confusórios e na tutela da atividade empresarial contra a usurpação foi reconhecida pelo STJ em INPI vs. Gang Comércio e Vestuário (BRASIL, 2011b): "Apesar de as formas de proteção ao uso das marcas e do nome de empresa serem diversas, a dupla finalidade que está por trás dessa tutela é a mesma: proteger a marca ou o nome da empresa contra usurpação e evitar que o consumidor seja confundido quanto à procedência do produto".
} 
seu objetivo de proteger a reputação empresarial, impedir comportamentos oportunistas de terceiros e proteger o consumidor contra atos confusórios.

Se a exclusividade fosse autorizada para além dos limites da categoria na qual o produto ou serviço se insere, sua função de distintividade perderia sentido. Em condições normais, uma marca de sorvete não precisa ser distintiva dentro de uma categoria de carros. Por essa razão, a lei apenas confere a exclusividade de uso do signo dentro de uma categoria de produtos idênticos ou semelhantes.

Nesse contexto, explica Barbosa (2008, p. 197) que o princípio da especialidade é adequado na medida em que promove o investimento na imagem e reputação do produto ou serviço ao mesmo tempo em que impede "a ampliação dos poderes de mercado além do necessário para viabilizar a marca no microambiente econômico onde ela se exerce".

\section{Afinidade}

Em determinadas situações, a legislação marcária também autoriza a exclusividade do uso da marca para além da classe de produtos ou serviços a que pertence, desde que a outra classe de produto em que poderá exercer sua exclusividade mantenha afinidade com a classe original. Nesse sentido, dispõe o art. 123, inciso I, da LPI que a marca de produto ou serviço será utilizada para distinguir produto ou serviço não apenas idêntico ou semelhante, mas também afim.

Para avaliar os limites da afinidade, será necessário considerar, no caso concreto, se os produtos e serviços tendem a uma mesma área comercial, se são comercializados no mesmo estabelecimento, se estão dirigidos ao mesmo grupo de consumidores, se possuem mesmas finalidades ou se são complementares (COPETTI, 2010), dentre outros aspectos.

A afinidade, portanto, representa uma exceção ao princípio da especialidade. Reflete aquelas situações em que a marca adquire eficácia fora da classe na qual fora originalmente registrada em um contexto em que esta proteção se faz necessária para proteger o consumidor contra confusão (COPETTI, 2010) e, assim, manter a eficácia denotativa da marca. Conforme Barbosa (2008, p. 204), “a afinidade 
irá até - e nunca mais além -, o necessário a garantir a eficácia da exclusividade, sem ampliá-la”.

Extravasamento do símbolo (ultraespecialidade)

Segundo Barbosa (2008, p. 133), há situações nas quais a imagem da marca "cria eficácia simbólica além do alcance da concorrência e dos direitos de exclusiva. Ou seja, o significante da marca (...) - aponta origens - que não necessariamente correspondem à circulação de produtos e serviços. O símbolo extravasa o mercado (...)".

Esse fenômeno é conhecido por notoriedade. Em razão de sua reputação e prestígio, o poder evocativo da marca ultrapassa os limites de seu mercado, de produto ou geográfico (BARBOSA, 2008). Trata-se da marca notória, cuja proteção, no âmbito da LPI, dá-se pela disciplina da marca de alto renome, prevista no art. 125, e da marca notoriamente conhecida, disposta no art. 126.

A marca de alto renome mitiga o princípio da especialidade. Em razão de sua fama e reputação no território brasileiro, é "assegurada proteção especial, em todos os ramos de atividade" (art. 125, LPI). Por sua vez, a marca notoriamente reconhecida em seu ramo de atividade, nos termos do art. $6^{\circ}$ bis (I) da Convenção da União de Paris, mitiga o princípio da territorialidade, ${ }^{64}$ na medida em que extravasa o alcance político do direito exclusivo, "gozando de proteção especial, independentemente de estar previamente depositada ou registrada no Brasil" (art. 126, LPI).

Protege-se a marca notória para, em primeiro lugar, evitar que o processo competitivo seja assolado pela concorrência parasitária de empresas que, buscando usurpar da reputação de outra, adquirem vantagens econômicas para atuar em um mercado em que a titular da marca notória não compete. A ideia, portanto, é evitar free riders que se desenvolvam à custa de terceiros e não por méritos próprios.

\footnotetext{
${ }^{64}$ Segundo Copetti (2010, p. 50), "o princípio da territorialidade determina que a proteção conferida às marcas não transcenda os limites territoriais do país e que somente nesse espaço físico seja reconhecido o direito de propriedade e a exclusividade de uso da marca registrada. (...) O princípio da territorialidade está amparado no artigo 129 da Lei $\mathrm{n}^{\circ} .9 .279 / 1996$, que dispõe que 'a propriedade da marca adquire-se pelo registro validamente expedido, conforme as disposições desta Lei, sendo assegurado ao titular seu uso exclusivo em todo o território nacional"”.
} 
Em segundo lugar, objetiva-se impedir a confusão do consumidor. Segundo Olavo (2005, p. 284), "quando o consumidor num mundo de comércio dominado pelos conglomerados (...) vê produtos, ainda que distintos, com a mesma marca, é natural que as associe ao titular da notória".

Em terceiro lugar, busca-se proteger a boa fama construída pelo seu titular, impedindo o esvaziamento do poder sugestivo de sua marca (OLAVO, 2005).

\section{(iv) Marcas não-registráveis}

Para que as marcas possam cumprir sua função de indicação de origem e distintividade dentro do processo competitivo, a LPI proíbe, dentre outros, o registro de (a) sinais que induzam à falsa indicação de origem ou procedência do produto, (b) sinais que carecem de distintividade e (c) sinais que induzem a confusão ou associação em relação a nomes de empresas ou estabelecimentos.

Dentre as marcas não-registráveis que induzam à falsa indicação de origem ou procedência do produto estão as hipóteses previstas nos incisos IX, X e XII da LPI, quais sejam: a indicação geográfica, sua imitação suscetível de causar confusão ou sinal que possa falsamente induzir indicação geográfica; o sinal que induza a falsa indicação quanto à origem, procedência, natureza, qualidade ou utilidade do produto ou serviço a que a marca se destina; e a reprodução ou imitação de sinal que tenha sido registrado como marca coletiva ou de certificação por terceiro, respectivamente.

Com relação aos sinais que carecem de distintividade, podem-se citar as proibições relativas aos incisos II, VI, VIII, XVIII, XIX, XXI, XXII e XXIII da LPI que assim estabelecem:

“ II - letra, algarismo e data, isoladamente, salvo quando revestidos de suficiente forma distintiva;

(...)

VI - sinal de caráter genérico, necessário, comum, vulgar ou simplesmente descritivo, quando tiver relação com o produto ou serviço a distinguir, ou aquele empregado comumente para designar uma característica do produto ou serviço, quanto à natureza, nacionalidade, peso, valor, qualidade e época de produção ou de 
prestação do serviço, salvo quando revestidos de suficiente forma distintiva;

(...)

VIII - cores e suas denominações, salvo se dispostas ou combinadas de modo peculiar e distintivo;

(...)

XVIII - termo técnico usado na indústria, na ciência e na arte, que tenha relação com o produto ou serviço a distinguir;

XIX - reprodução ou imitação, no todo ou em parte, ainda que com acréscimo, de marca alheia registrada, para distinguir ou certificar produto ou serviço idêntico, semelhante ou afim, suscetível de causar confusão ou associação com marca alheia;

$(\ldots)$

XXI - a forma necessária, comum ou vulgar do produto ou de acondicionamento, ou, ainda, aquela que não possa ser dissociada de efeito técnico;

XXII - objeto que estiver protegido por registro de desenho industrial de terceiro; e

XXIII - sinal que imite ou reproduza, no todo ou em parte, marca que o requerente evidentemente não poderia desconhecer em razão de sua atividade, cujo titular seja sediado ou domiciliado em território nacional ou em país com o qual o Brasil mantenha acordo ou que assegure reciprocidade de tratamento, se a marca se destinar a distinguir produto ou serviço idêntico, semelhante ou afim, suscetível de causar confusão ou associação com aquela marca alheia."

Por fim, os sinais que induzam a confusão ou associação em relação a nomes de empresas ou estabelecimentos não são registráveis, nos termos do inciso $\mathrm{V}$ do art. 124 da LPI. Conforme explica Silveira (2011), o nome empresarial, assim como a marca, representa um direito exclusivo. No entanto, não está limitado ao ramo de atividade, uma vez que envolve a identificação do empresário comercial, industrial ou do prestador de serviços em todas as suas relações. Disto decorre que o nome empresarial poderá impedir seu uso como marca por terceiros em qualquer ramo. 
As regras de concorrência desleal encontram-se disciplinadas na LPI e, juntamente com a disciplina dos direitos de propriedade industrial, formam um corpo unitário com funções e objetivos comuns.

Nesse sentido, o direito da propriedade industrial e o direito da concorrência desleal são dois lados de uma mesma moeda. De um lado, estabelecem-se direitos que permitem aos seus titulares a utilização, de forma exclusiva, de símbolos; de outro, estabelecem-se deveres recíprocos aos sujeitos econômicos para que todos atuem de maneira honesta e leal (OLAVO, 2005).

No contexto marcário, a concorrência desleal constitui fundamento para a anulação de registros das marcas, dos nomes e das insígnias (OLAVO, 2005) e representa a base para que titulares de marcas, registradas ou não registradas, ${ }^{65}$ impeçam que terceiros realizem atos ilícitos ou fraudulentos que possam desviar-lhes a clientela. Ademais, na disciplina do crime de concorrência desleal, aqueles ilícitos cometidos contra marca de alto renome, notoriamente conhecida e de certificação ou coletiva têm a penalidade agravada por força do art. 196 da LPI.

De modo geral, a repressão da concorrência desleal visa à proteção da liberdade de concorrência em seu sentido subjetivo, isto é, a liberdade do agente econômico de atuar e desenvolver-se no mercado. Para tanto, nos termos do item 2 do artigo 10-bis da Convenção da União de Paris, busca combater "qualquer ato de concorrência contrário aos usos honestos em matéria industrial e comercial" que tenham o condão de causar prejuízo à concorrente pela usurpação total ou parcial de sua clientela. Deslealdade e desvio de cliente, portanto, são dois requisitos fundamentais para a existência de concorrência desleal.

Na LPI, uma lista de atos que podem configurar concorrência desleal está disposta no art. 195. Embora essa lista seja taxativa sob a perspectiva do Direito Penal, uma vez que a LPI considera os atos lá descritos como crimes, ela não é taxativa do ponto de vista civil, na medida em que, a partir da dinâmica do mercado, outras práticas possam ser consideradas desonestas e desleais e, portanto, suscetíveis à reparação do

\footnotetext{
${ }^{65}$ No caso das marcas sem registro, o utente não fica desamparado na medida em que pode socorrer-se nas normas de concorrência desleal (SILVEIRA, 2011).
} 
ponto de vista civil, nos termos do art. 209 da LPI e também dos artigos 186 e 927 do Código Civil.

Embora não seja uma classificação estanque, a doutrina especializada classifica os atos de concorrência desleal em (a) atos de confusão, (b) atos de descrédito, (c) atos de apropriação e (d) atos de desorganização (OLAVO, 2005).

Os atos de confusão são aqueles que têm por objetivo criar confusão no espírito do consumidor, de maneira que o induza a confundir determinado produto ou serviço com o de concorrente. Citam-se, como exemplo, as práticas descritas nos incisos III e IV do art. 195 da LPI: "comete crime de concorrência desleal quem: (...) III emprega meio fraudulento, para desviar, em proveito próprio ou alheio, clientela de outrem; IV - usa expressão ou sinal de propaganda alheios, ou os imita, de modo a criar confusão entre os produtos ou estabelecimentos".

No campo marcário, os atos confusórios têm particular relevância no que se convencionou chamar de "trade-dress", o qual representa o aspecto visual do produto ou estabelecimento, podendo compreender, no primeiro caso, "o formato, a cor ou combinação de cores, o tamanho, a textura, gráficos, desenhos, rótulos e disposição de elementos visualmente perceptíveis" e, no segundo caso, "o conjunto de elementos que caracterizam lojas, armazéns, restaurantes e outros recintos, quer sejam internos, quer sejam externos" (OLAVO, 2005, p. 292). De acordo com Dias (2013, p. 295), "as empresas (...) não podem se apropriar do 'trade-dress' ou 'conjunto-imagem' de um terceiro, pois tal situação gera confusão no público consumidor com consequente desvio de clientela. Trata-se de ato de concorrência desleal (...)".

Os atos de descrédito são aqueles que têm como objetivo desacreditar um concorrente, desprestigiando sua atividade. Englobam aquelas práticas denigritórias ou que envolvam informações falsas com relação a concorrentes. Estão exemplificados nos incisos I e II do art. 195 da LPI: “comete crime de concorrência desleal quem: I publica, por qualquer meio, falsa afirmação, em detrimento de concorrente, com o fim de obter vantagem; II - presta ou divulga, acerca de concorrente, falsa informação, com o fim de obter vantagem".

Os atos de apropriação, por sua vez, ocorrem não necessariamente por meio do descrédito a concorrentes, "mas pelo fato de um empresário se apropriar de elementos, qualidades ou características que não lhe pertençam nem dizem respeito" 
(OLAVO, 2005, p. 278). Estão refletidos nos incisos V, VI e VII do art. 195 da LPI: "comete crime de concorrência desleal quem: (...) V - usa, indevidamente, nome comercial, título de estabelecimento ou insígnia alheios ou vende, expõe ou oferece à venda ou tem em estoque produto com essas referências; VI - substitui, pelo seu próprio nome ou razão social, em produto de outrem, o nome ou razão social deste, sem o seu consentimento; VII - atribui-se, como meio de propaganda, recompensa ou distinção que não obteve".

Os atos de desorganização, por fim, são aqueles que visam provocar efeitos adversos ao normal funcionamento de um concorrente. Incluem-se neles o desvio de empregados, a divulgação ilícita de segredos de indústria e informações comercialmente sensíveis, dentre outros, também exemplificados nos incisos IX a XIV do art. 195 da LPI.

Como se vê, portanto, são diversas as regras da legislação ordinária que reforçam a ideia da marca como uma "propriedade constitucional que se realiza na concorrência e pela concorrência" (BARBOSA, 2008, p. 241). Todas elas buscam concretizar a função da marca na proteção dos investimentos na reputação empresarial, na proibição a comportamentos oportunistas e na proteção do consumidor de modo que o instituto, de fato, possa ser utilizado como um instrumento a favor da regular manutenção do processo competitivo.

\subsection{Questões práticas derivadas da incidência de múltiplos condicionantes: interações entre as diversas esferas e potenciais conflitos decisórios}

Conforme verificado nos itens acima, o exercício de um direito marcário está sujeito a diversas regras relativas à disciplina do direito concorrencial, do direito do consumidor e do direito da propriedade industrial (na qual se inclui a disciplina da concorrência desleal). Embora não se tenha tratado em detalhe nas seções acima, o uso da marca também está sujeito à disciplina do Direito Penal, nos termos dos artigos 189 , 190 e 195 da LPI.

Os ilícitos que afetem direitos do consumidor poderão, em geral, ser objeto de (a) investigação no âmbito dos PROCONS e, ainda, (b) ações individuais ou coletivas perante o Judiciário. Os atos que envolvam violação a direitos de propriedade 
industrial poderão, grosso modo, ser objeto de (a) exame do INPI no contexto, por exemplo, de oposições a registros (art. 158 da LPI) e pedidos administrativos de nulidade (art. 168 da LPI) e (b) medidas perante o Judiciário, seja no âmbito de ações de nulidade, nos termos do art. 173 da LPI, seja no contexto de ações individuais que visem impedir atos de concorrência desleal de terceiros e também que busquem reparação (art. 209 da LPI), dentre outras. Práticas que resultem em infração concorrencial poderão ser (a) analisadas administrativamente no âmbito do CADE e, (b) judicialmente, em ações de natureza reparatória. Crimes contra as marcas e de concorrência desleal também poderão ser analisadas pela jurisdição penal. São inúmeras, portanto, as esferas a que está sujeito um agente econômico que utilize indevidamente sua marca ou a marca de outrem, conforme se verifica na Figura 2.1.

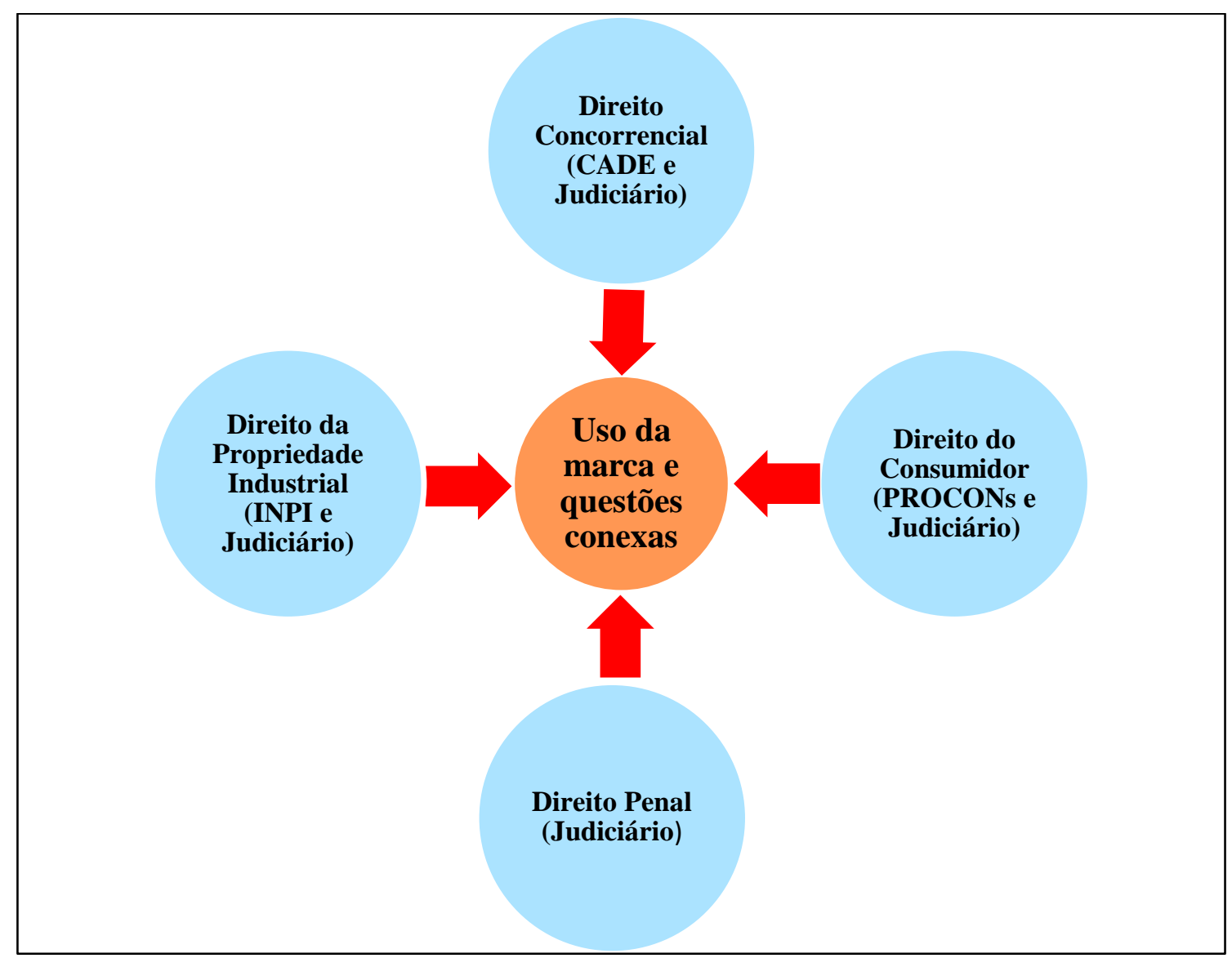

Figura 2.1 - Instâncias de análise de questões marcárias.

Nesse contexto, a questão prática que se coloca é: diante de um ato que tenha implicações nas diversas áreas (Direito do Consumidor, Direito Concorrencial, Direito da Propriedade Industrial e Direito Penal), como se lida com um potencial 
conflito ou contradição nos provimentos das diferentes instâncias decisórias (PROCONs, CADE, INPI, Judiciário)?

Em primeiro lugar, é necessário ressaltar que cada instância decisória é independente e analisará o ato considerando os propósitos e os limites de sua área de atuação e sua competência. $\mathrm{O}$ enfoque, portanto, de análise da conduta à luz dessas quatro áreas será distinta na medida em que estes ramos do Direito também são autônomos.

Sob a perspectiva do Direito do Consumidor, a abordagem, naturalmente, recai sobre os efeitos da conduta sobre o consumidor, cuja vulnerabilidade a instância decisória buscará corrigir, recompondo, assim, a igualdade jurídica entre as partes. Há, ainda, uma preocupação central com o direito de escolha do consumidor e, consequentemente, com a adequação e clareza das informações que ele recebe (MIRAGEM, 2014).

Com relação ao Direito da Propriedade Industrial, o enfoque será mais formalista, quando se trate de uma situação em que a natureza de direito real da marca esteja em destaque (i.e. análise da validade e/ou nulidade de um registro). No entanto, quando o caráter concorrencial desse instituto estiver em jogo (e.g. em uma hipótese de ato de concorrência desleal), a análise tenderá a concentrar-se em aspectos éticos e morais da conduta do agente (lealdade) bem como buscará, em um exame mais concreto do funcionamento do mercado, verificar se há possibilidade de desvio de clientela e dano a concorrentes individualmente considerados.

No que tange ao Direito da Concorrência, a preocupação central é a manutenção do valor concorrência num sentido objetivo (em oposição à proteção de concorrentes). Aqui, as regras de proteção a direitos individuais econômicos não são suficientes para atender às necessidades coletivas. $\mathrm{O}$ foco da análise é se a conduta tem o condão de afetar o processo competitivo.

Para tanto, é preciso não só garantir a lealdade do processo (o que a disciplina da concorrência desleal cuida), isto é, "que o sucesso das empresas do mercado dependa exclusivamente de sua eficiência, e não de sua 'esperteza negocial"” (SALOMÃO FILHO, 2007, p. 55), mas também a manutenção direta do equilíbrio das interações econômicas. Para garantir de forma ampla a concorrência, a análise das condutas faz-se no campo das potencialidades. Ou seja, não é necessário um dano real à 
concorrência, a mera potencialidade de dano já é sancionável. Com isso, busca-se transmitir ao mercado, de forma mais célere e eficiente, o recado sobre o padrão comportamental esperado de maneira a evitar perigos que possam resultar em uma lesão concreta à concorrência.

No caso do Direito Penal, por sua vez, o enfoque da análise recairá sobre o elemento subjetivo do agente que realiza a conduta. A verificação do dolo ou da culpa do agente é fundamental para o juiz que analisa a causa, independentemente dos efeitos da conduta sobre o consumidor, sobre concorrentes ou sobre a concorrência.

É natural que cada ramo de direito tenha seus próprios princípio e metodologias de análise. A análise de um problema realizada por determinada área do Direito, mas com enfoque de outro ramo poderia gerar sérios problemas. A título ilustrativo, uma abordagem de uma infração antitruste sob o olhar consumerista poderia gerar um resultado que contraria os próprios interesses tutelados pelo Direito Concorrencial. Nesse sentido, "um raciocínio baseado exclusivamente no interesse imediato do consumidor poderia considerar lícita a prática, pois os preços, no curto prazo, evidentemente os beneficiam” (SALOMÃO FILHO, 2007, p. 85)

Ademais, dados os diferentes enfoques, não é incomum que a análise de uma mesma conduta produza resultados diversos.

Considere-se, a título ilustrativo, que um agente com posição dominante seja investigado por imitar marcas de concorrentes. Imagine-se que, de fato, haja evidências de que o objetivo do agente com posição dominante era excluir rivais do mercado. No entanto, no momento de implementar a ação, a agência de publicidade contratada pela empresa não executou o plano satisfatoriamente e a suposta imitação não tinha o condão de causar confusão ao consumidor tampouco de desviar clientela de concorrentes. Nesse caso, é possível que, numa ação na qual estes concorrentes busquem a declaração de nulidade dessas marcas imitativas perante o Judiciário, este as considerem válidas, ou em uma ação de reparação por concorrência desleal, o juiz entenda que não houve dano aos concorrentes. Ao mesmo tempo, o CADE, verificando que a conduta do agente tinha por objeto a dominação de mercado relevante, poderá sancioná-lo do ponto de vista da legislação antitruste.

Em outro exemplo, suponha que um agente com posição dominante tenha solicitado o registro no Brasil de marcas idênticas às de diversos concorrentes, as quais 
sejam de conhecimento notório em outras jurisdições. Presuma-se, ainda, que aquele mesmo agente, por algum motivo, tinha ciência dos planos desses concorrentes de entrar no mercado brasileiro.

A marca notória, conforme já mencionado, goza de proteção especial, nos termos do art. 126 da LPI. Desse modo, a princípio, não se pode registrar uma marca que imite ou reproduza, no todo ou em parte, marca notória. Todavia, há uma divergência de interpretação do art. 6 bis da Convenção da União de Paris que estabelece que os países signatários deverão recusar, invalidar ou proibir o uso de marca que constitua contrafação "de uma marca que a autoridade competente do país de registro ou do uso considere que nele é notoriamente conhecida como sendo a marca de uma pessoa amparada pela presente Convenção, e utilizada para produtos idênticos ou similares". Diante da posição do vocábulo "nele" no dispositivo, há dúvidas se a marca estrangeira, para receber tutela do artigo 6 bis, deverá ser tanto conhecida notoriamente no Brasil como utilizada no território brasileiro (SILVEIRA, 2011).

Neste contexto, suponha que o INPI, ao analisar o pedido de registro dessas marcas considere que o uso da marca no Brasil é requisito necessário para que a marca seja considerada notoriamente reconhecida ${ }^{66}$ e que as marcas cujo registro foi solicitado pelo agente com posição dominante não preencham esse requisito. Neste cenário, muito provavelmente, o INPI considerará que o registro dessas marcas é válido. A autoridade concorrencial, por sua vez, verificando que a ação do agente com posição dominante tem por objetivo ou efeito impedir a entrada de rivais no mercado e aumentar o seu poder de mercado, pode sancionar a ação do agente, nos termos da Lei $n^{\circ}$. $12.529 / 2011$.

Diante desses exemplos, pode-se notar como a natureza da análise de cada esfera produz resultados diversos para um mesmo ato, o que pode parecer conflitante. Nos exemplos acima, têm-se marcas consideradas válidas pela autoridade da propriedade industrial, cujo uso, porém, foi considerado anticoncorrencial pela autoridade antitruste.

\footnotetext{
${ }^{66}$ Note que este, a princípio, não é o entendimento corrente do INPI que entende que "tendo em vista que a Convenção de Paris não dá qualquer definição de notoriedade, nem, tampouco, estabelece critérios para sua apreciação, o INPI, na qualidade de autoridade competente para apreciar matéria dessa natureza, considera a questão observando se a marca possui certo conhecimento no Brasil, no segmento de mercado idêntico ou similar" (BRASIL, 2012b).
} 
Esse aparente conflito, todavia, é natural em um sistema orientado (a) pela autonomia dos ramos do Direito (no caso, do Direito do Consumidor, Direito Antitruste, Direito da Propriedade Intelectual e Direito Penal), (b) pela independência das esferas cível, penal e administrativa, e (c) pela independência das autarquias federais.

A existência dos diversos ramos do Direito decorre da necessidade de domínio de cada uma das matérias, que devem ter regras próprias a partir das quais seja possível garantir ao ordenamento jurídico a "decidibilidade de conflitos com um mínimo de perturbação social" （FERRAZ JR, 2003, p. 140).

Ademais, o Poder Judiciário, de um lado, e a esfera administrativa, de outro, servem a diferentes fins, possuem naturezas distintas e exercem um papel também distinto nas atividades que disciplinam (ENTERRÍA; FERNANDEZ, 2000).

Dessa maneira, o entendimento de um juiz cível em uma ação de nulidade de marca não vincula a decisão do CADE em um processo versando sobre conduta anticoncorrencial, as decisões do INPI não vinculam o $\mathrm{CADE}^{67}$ e vice-versa, dentre outros exemplos. Tratam-se de microssistemas jurídicos que, em última instância, cumprem, cada qual, com sua função dentro da política pública a que estão destinados a implementar.

Ao discutir o enfoque diferenciado a que as condutas estão sujeitas nas diferentes esferas, o então Conselheiro Marcos Paulo Veríssimo, em voto no caso McDonald's, consignou que:

"nos casos de delitos de concorrência, especialmente aqueles distintos do cartel, o ponto sempre foi muito menos determinar se certos fatos ocorreram ou não, e muito mais determinar sua antijuridicidade, que

\footnotetext{
${ }^{67}$ Em SDE v. TECONDI e outros, o CADE pronunciou-se no sentido de que "é evidente que a atividade judicante do CADE - que decorre de expressa determinação constitucional, quando determina que a lei reprimirá o abuso do poder econômico (art. $173, \S 4^{\circ}$, da $\mathrm{CR} / 88$ ) - não pode ficar condicionada à existência ou não de regulação específica para determinada matéria. (...) Não é o CADE um 'revisor' de políticas públicas, porque em agindo assim, estaria atentando contra os postulados básicos da legalidade e de toda a doutrina que informa a atividade dos órgãos reguladores. Entretanto, deparando-se com situações que podem configurar infração à ordem econômica, é dever das autoridades antitruste investigar e julgar tais condutas, nos estritos termos da Lei $n^{\circ}$. 8.884/94, de resto em perfeita harmonia com o arcabouço jurídico-institucional vigente. Assim, (...) certa conduta ou atividade (...) deverão ser analisadas, neste Conselho, sob o prisma da lei de concorrência" (BRASIL, 2005, p. 3).
} 
podia, inclusive, ser distinta nos campos penal e administrativo" (BRASIL, 2014c, p. 17).

A antijuridicidade, portanto, de uma conduta que envolva direitos marcários poderá ser diferente a depender do ramo de Direito e a respectiva instância responsável pela análise. Todavia, isso não significa, em absoluto, que a decisão de uma instância não possa influenciar a decisão de outra. Como explicitado pelo então Conselheiro Olavo Chinaglia no mesmo caso:

"eventual advento de uma investigação criminal sobre o mesmo fato, embora possa influenciar o julgamento inclusive quanto às questões de fundo, como a ocorrência ou não de determinada conduta ou sua autoria (...), jamais poderia ser interpretado como um requisito para a ação administrativa (...)" (BRASIL, 2014c, p. 17).

A ideia, portanto, sem pretender esgotar tema deveras complexo é que os ramos de Direito são autônomos e as respectivas instâncias decisórias são independentes, o que não significa que questões de mérito analisadas por uma esfera não poderão ser utilizadas como parâmetros interpretativos para outra. A título ilustrativo, na análise de uma violação do direito de marca sob a ótica da LPI, a questão do consumidor pode ser um aspecto relevante a ser considerado na decisão quando se analise o risco de confusão ou de associação no público causado por determinado sinal. Nesse caso, percebe-se uma intersecção da disciplina de proteção jurídica das marcas e do direito à informação do consumidor (MIRAGEM, 2014), o que não significa que a autoridade julgadora da violação ao direito à marca esteja adstrita à decisão da autoridade que julgou a questão sob a ótica do direito à informação do consumidor, nos termos do art. $6^{\circ}$, inc. III, do CDC.

No âmbito do Direito Penal, contudo, pela própria natureza de ultima ratio desse sistema, que age apenas diante da ineficácia de outros mecanismos de inibição de condutas, não é lógico aceitar que uma conduta que seja considerada lícita ou aceitável no campo administrativo ou cível seja considerado um injusto penal. A existência de justa causa para a persecução penal exige a verificação do desvalor da conduta para todas as outras instâncias (cível e administrativa). Do contrário, o princípio basilar do Direito Penal - a ultima ratio da intervenção penal e sua fragmentariedade - 
restará corrompido. Nesse sentido, embora a ação penal seja independente dos processos em outras instâncias, do ponto de vista material, somente poderá haver um ilícito penal se houver também uma conduta antijurídica do ponto de vista cível ou administrativo (BOTTINI, 2013). 


\section{CAPÍTULO 3. MARCAS E O CONTROLE DE ESTRUTURAS}

\subsection{Introdução}

Uma avaliação do histórico de operações analisadas pelo CADE desde a sua criação demonstra que as operações mais complexas e que exigiram maior nível de intervenção envolviam, dentre outros aspectos, a transação de direitos sobre marca. Este é o caso de Colgate/Kolynos (BRASIL, 1996b), constituição da Ambev (BRASIL, 2000a), Sadia/Perdigão (BRASIL, 2011a), JBS/Rodopa (BRASIL, 2014a), dentre outros.

Conforme se verá abaixo, o papel das marcas nos atos de concentração não é trivial e está bem caracterizado na análise econômica das transações. A marca permeia todas as etapas da análise de uma operação envolvendo mercados diferenciados, em especial, a definição do mercado relevante e o exame da probabilidade de exercício de poder de mercado. ${ }^{68}$ São também ativos fundamentais no estabelecimento de remédios e em negociações de acordos em atos de concentração.

Este capítulo buscará, em primeiro lugar, analisar questões envolvendo a necessidade de submissão de contratos de licenciamento de marcas, uma vez que há certa insegurança jurídica quanto a este tema.

Ao contrário da Lei $n^{\circ}$. 8.884/1994, que estabelecia em seu art. 54 que todos os atos que pudessem falsear a concorrência ou resultar na dominação de mercado relevante, independentemente de sua forma, deveriam ser notificados ao CADE, a Lei $\mathrm{n}^{\mathrm{o}}$. 12.529/2011, em seu art. 90, definiu restritivamente os parâmetros do que deva se considerar um ato de concentração, nos quais estão incluídas as fusões, aquisições de controle ou partes de uma empresa, incorporações, contratos associativos, consórcios e joint ventures.

Entretanto, a depender da interpretação que se dê a certos conceitos ambíguos trazidos pela citada lei, mais especificamente, "contratos associativos", é

\footnotetext{
${ }^{68}$ Segundo o Guia de Análise de Atos de Concentração brasileiro, "para determinar se existem condições suficientes para que o poder de mercado seja exercido unilateralmente pela empresa, ou coordenadamente por um grupo de empresas, a SEAE e a SDE procederão à análise de quatro variáveis principais: (a) importações; (b) entrada; (c) efetividade da rivalidade; e (d) outros fatores que favorecem a coordenação de decisões" (BRASIL, 2001).
} 
possível que se limite demasiadamente o escopo da norma, deixando escapar do escrutínio da autoridade concorrencial atos verdadeiramente concentracionistas.

Em segundo lugar, discute-se a influência das marcas na definição do mercado relevante. A marca é uma importante ponte entre uma empresa e seu cliente. Por meio dela, o produtor ou o varejista busca distinguir o seu produto daquele dos concorrentes. Visa, assim, torna-lo único, de maneira que não exista uma "mesma mercadoria" (LEVITT, 1990, p. 85).

Dessa forma, a pergunta que se faz, do ponto de vista antitruste, é como delimitar adequadamente mercados relevantes quando a marca resulta na diferenciação de produtos funcionalmente similares. Esse questionamento é de extrema importância, sobretudo num cenário em que o poder de mercado é geralmente inferido dos níveis de participação de mercado detidos pelas empresas ${ }^{69}$ e uma definição errônea de mercado pode trazer prejuízos à concorrência e ao bem estar do consumidor.

Em terceiro lugar, este capítulo buscará abordar o papel da marca no exame de probabilidade de exercício de poder de mercado. Nesse aspecto, será analisada a influência da marca na constatação de barreiras à entrada e na rivalidade entre as firmas.

Por fim, são discutidas as bases legais para a aplicação de remédios em atos de concentração envolvendo a alienação, licenciamento e suspensão do uso de direitos de propriedade industrial e, ainda, será analisada sua efetividade em alguns casos submetidos ao controle do CADE.

A jurisprudência desse órgão revela alguns exemplos em que foram impostas limitações dessa natureza. Em sendo a marca um importante ativo concorrencial de uma empresa, não é incomum que sejam objeto de restrições comportamentais e estruturais aplicadas pelo órgão de defesa da concorrência. A propriedade aqui se mostra amplamente transacionável sobretudo em um contexto em que a autoridade concorrencial, ao exercer sua competência no controle estrutural de atos de concentração, está orientada pelo princípio da precaução, "que obriga a autoridade julgadora a adotar, na solução do seu problema de decisão, uma atitude

\footnotetext{
${ }^{69}$ Embora seja incorreto inferir poder de mercado da participação de mercado detida por determinada empresa, a própria lei antitruste cria uma presunção de posição dominante quando uma firma detém $20 \%$ ou mais do mercado relevante.
} 
conservadora e de aversão ao risco de que concentrações econômicas anticompetitivas venham a ser aprovadas" (BRASIL, 2006, p. 15).

Com base na análise de algumas dessas decisões proferidas pela autoridade brasileira serão, por fim, apresentadas algumas considerações sobre a efetividade e adequação de medidas comportamentais vis-à-vis remédios estruturais.

\subsection{Da necessidade de notificação de contratos de licenciamento}

A Lei $n^{\circ} .12 .529 / 2012$ é bastante clara no que diz respeito à necessidade de submissão de operações que envolvam a cessão de direitos de propriedade industrial. Dispõe o art. 90, inciso II, que se realiza um ato de concentração quando "1 (uma) ou mais empresas adquirem, direta ou indiretamente, por compra ou permuta de ações, quotas, títulos ou valores mobiliários conversíveis em ações, ou ativos, tangíveis ou intangíveis, por via contratual ou por qualquer outro meio ou forma, o controle ou partes de uma ou outras empresas".

Nesse sentido, não há dúvidas de que a aquisição por meio de compra ou permuta de ativos intangíveis, no qual se incluem marcas e patentes, deverá ser submetida ao CADE, nos termos da nova lei concorrencial.

A questão torna-se mais complexa para os casos de licenciamento. A legislação antitruste brasileira traz hipóteses taxativas do que é considerado um ato de concentração. Além da hipótese de aquisição tratada acima, também são considerados atos de concentração as fusões, incorporações, contratos associativos, consórcios ou

joint venture. ${ }^{70}$ Nesse contexto, os contratos de licenciamento somente seriam notificáveis se pudessem ser enquadrados dentro de um desses conceitos.

Excluídas as hipóteses de fusões, incorporações, consórcios e joint ventures, que não têm qualquer relação com contratos de licenciamento, restaria, na realidade, analisar se contratos de licenciamento se enquadrariam na definição de contratos associativos.

\footnotetext{
${ }^{70}$ Artigo 90 da Lei no ${ }^{\circ}$ 12.529/2012.
} 
3.2.1. Contratos de licenciamento de PI como contratos associativos: os casos Monsanto e a nova regulamentação do CADE

(i) Casos Monsanto

Em 2013, o CADE analisou a subsunção de contratos de licenciamento no qual a Monsanto concedia a determinadas empresas licença não exclusiva para desenvolver, testar, produzir e comercializar certas variedades de sementes de soja além de licença de marca Intacta RR2 Pro (em conjunto, “casos Monsanto”). Embora os atos de concentração correspondentes tenham sido submetidos sob a égide da legislação anterior (Lei $\mathrm{n}^{\circ} .8 .884 / 94$ ), na oportunidade, foi discutido se o contrato de licenciamento poderia ser considerado um contrato associativo, nos termos da nova Lei.

A Conselheira Ana Frazão entendeu que esse tipo de contrato era comutativo, uma vez que uma das partes cedia a outra o direito de usar determinado direito mediante remuneração. As partes executariam o contrato por sua conta e risco sem qualquer interferência nas atividades uma das outras. Para a Conselheira, só seria possível considerar esse tipo de contrato como associativo caso se adotasse uma noção muito ampla de cooperação, o que poderia ampliar indevidamente as categorias de contrato que estariam sob essa definição (BRASIL, 2013b).

Em sua opinião, para que restasse configurado um contrato associativo, seria fundamental a presença de elementos que indicassem alguma forma de integração dos centros decisórios das partes envolvidas ou, pelo menos, de perda da independência das partes contratantes, o que, para ela, não era o caso dos contratos da Monsanto. Dessa maneira, concluiu seu voto opinando pelo não conhecimento dos atos. Para ela, a intenção do legislador foi restringir os atos de submissão obrigatória, limitando as hipóteses para os casos de "alta probabilidade de risco anticoncorrencial", o que não era o caso dos contratos de licenciamento não exclusivo da Monsanto.

Sem discordar do posicionamento da Conselheira Ana Frazão, o Conselheiro Eduardo Pontual, em voto vencedor, identificou nos contratos da Monsanto cláusulas que efetivamente alteravam a relação de concorrência entre as partes, conferindo à Monsanto uma capacidade de influir em decisões comerciais estratégicas das empresas contratantes, em função de regras de remuneração e de compartilhamento 
de riscos. Nesse sentido, entendeu que, da forma como o contrato estava configurado, havia "restrições à atuação concorrencial independente das licenciadas e um empreendimento comum, o cultivar obtido, comercializado através dessas licenças" (g.n.) (BRASIL, 2013b), o que extrapolava muito o que seria esperado de um contrato comutativo.

Para esse Conselheiro, o conhecimento de contratos de transferência de tecnologia via contratos de licenciamento em cultivares dependeria "da existência de características contratuais que envolvam exclusividade no uso da capacidade produtiva da empresa licenciada, ou envolvam restrições ou desincentivos na escolha da contratação de outros licenciadores por parte da licenciada, ou envolvam restrições ao desenvolvimento de produtos concorrentes próximos do bem desenvolvido a partir do insumo ou evento licenciado" (BRASIL, 2013b).

Esse critério está em consonância com o entendimento de Veríssimo, que, embora tenha votado pelo não conhecimento no caso específico, defendeu o conhecimento de contratos de licenciamento quando estes representem empreendimentos em comum ou forma de atuação conjunta, prevejam cláusulas de exclusividade ou, ainda, resultem em influência na atuação concorrencial independente de ambas as partes.

Os votos desses Conselheiros deixam transparecer que determinados contratos de licenciamento de propriedade intelectual, de fato, poderiam enquadrar-se na noção de contrato associativo, previsto no art. 90, inc. IV, da Lei ${ }^{\circ}$. 12.529/2011, quando resultem em alguma ingerência comercial do licenciante nos negócios do licenciado que configure um empreendimento comum, o que, entende-se, está ligado à noção de uma influência relevante ${ }^{71}$ de uma empresa sobre a outra. Com efeito, nos casos Monsanto, havia cláusulas nos contratos que permitiam o controle da Monsanto

\footnotetext{
${ }^{71}$ Conforme definição adotada pelo então Conselheiro Ricardo Cueva no caso Ideasnet/Flynet (BRASIL, 2006) e retomada nos casos Log\&Print/Tecnicópias I (BRASIL, 2010e), Log\&Print/Tecnicópias II (BRASIL, 2009d) e TIM/Telefônica (BRASIL, 2010f), "constata-se influência relevante do ponto de vista concorrencial sempre que a partir da união dos centros decisórios em áreas específicas e estratégicas, seja possível presumir um comportamento cooperativo entre as empresas, o qual não pressupõe a maioria das ações votantes". Em SAP/Spring (BRASIL, 2010g), o CADE adota uma definição mais genérica de influência relevante, que seria "a capacidade de influenciar decisões concorrencialmente relevantes da empresa-objeto". No voto do Conselheiro Pontual nos casos Monsanto foi possível identificar algumas características de interdependência que qualificam os contratos associativos: "cláusulas que mostram os esforços para um bem comum"; "forma de financiamento do desenvolvimento de produtos de forma conjunta"; "influência concorrencial clara nos negócios"; e "sistema de incentivos que criam uma influência externa" (BRASIL, 2013b). Todos esses fatores guardam relação direta com a noção de influência relevante no Direito da Concorrência.
} 
sobre as licenciadas em decisões comerciais e societárias não relacionadas ao objeto dos contratos de licenciamento, o que deixa clara a influência relevante dessa companhia sobre as demais partes contratantes.

Neste cenário, os contratos de licenciamento não deveriam ser a priori excluídos do controle de estruturas, uma vez que podem representar um "meio de concentração contratual” (BURST, 1970, p. 19) e resultar em impactos concorrenciais.

(ii) Nova regulamentação do CADE sobre contratos associativos: Resolução $n^{o}$. $10 / 2014$

Decorrido mais de um ano após a decisão do CADE nos casos Monsanto, o Conselho editou a Resolução $n^{\circ}$. 10/2014, que buscou estabelecer um conceito mais objetivo para o termo "contratos associativos".

A norma deve ser entendida e aplicada no contexto dos esforços do CADE de reduzir o número de notificações obrigatórias, separando, por assim dizer, o joio do trigo, i.e. aquelas operações que tenham real e maior impacto sobre a concorrência, daquelas de caráter meramente repetitivo, com alto potencial de comprometer a higidez do controle prévio.

Com efeito, antes, o texto legal do art. 90, inciso IV, exigia a notificação de quaisquer contratos em que as partes (ou seus respectivos grupos econômicos) atendessem aos critérios de faturamento mínimo do art. 88, até porque a qualidade associativa pode ser atribuída genericamente a qualquer contrato. A Resolução, contudo, garante ao Administrado critérios mínimos e objetivos, os quais devem ser interpretados à luz do texto e contexto histórico da norma.

De acordo com a Resolução, "consideram-se associativos quaisquer contratos com duração superior a 2 (dois) anos em que houver cooperação horizontal ou vertical ou compartilhamento de risco que acarretem, entre as partes contratantes, relação de interdependência" (art. $2^{\circ}$ ).

Do ponto de vista temporal, portanto, apenas deverão ser notificados aqueles contratos associativos que tenham prazo superior a dois anos, ou, mais conservadoramente, que tenham prazo igual ou superior a dois anos, uma vez que o $\S 3^{\circ}$ 
do art. $2^{\circ}$ dispõe que "as contratos com duração inferior a dois anos devem ser notificados nos termos desta Resolução quando, mediante sua renovação, o período de 2 (dois) anos for atingido ou ultrapassado".

Sob uma perspectiva material, sempre que o contrato implicar uma “cooperação" - seja horizontal, seja vertical - e um "compartilhamento de risco" que acarretem "relação de interdependência" entre as partes, deverá ser notificado. Naturalmente, esses conceitos são bastante amplos e acabam gerando dúvidas adicionais sobre o escopo da definição de contratos associativos. Contudo, considerando o pronunciamento majoritário do CADE nos casos Monsanto, é possível aventar que a noção de influência relevante, adotada pelo CADE em diversos precedentes, pode ser utilizada como um parâmetro interpretativo para os conceitos de "cooperação", "compartilhamento de risco" e "relação de interdependência".

Na busca por um critério que conferisse maior previsibilidade aos agentes econômicos, o CADE ainda considerou, nos termos do art. $2^{\circ}, \S 1^{\circ}$, da Resolução $n^{\circ}$. 10/2014, que:

“ (..) há cooperação horizontal ou vertical ou compartilhamento de risco que acarretam relação de interdependência:

I - nos contratos em que as partes estiverem horizontalmente relacionadas no objeto do contrato sempre que a soma de suas participações no mercado relevante afetado pelo contrato for igual ou superior a vinte por cento (20\%); ou

II - nos contratos em que as partes contratantes estiverem verticalmente relacionadas no objeto do contrato, sempre que pelo menos uma delas detiver trinta por cento $(30 \%)$ ou mais dos mercados relevantes afetados pelo contrato, desde que preenchida pelo menos uma das seguintes condições:

a) o contrato estabeleça o compartilhamento de receitas ou prejuízos entre as partes;

b) do contrato decorra relação de exclusividade."

Com isso, o CADE criou uma presunção de que há cooperação ou compartilhamento de risco que acarretam relação de interdependência em todo e qualquer contrato, independente de sua natureza, em que as partes sejam vertical ou horizontalmente relacionadas ao seu objeto, desde que preenchidos os parâmetros de 
market share e, no caso específico de contratos verticais, haja cláusula de exclusividade ou de compartilhamento de receitas ou prejuízos.

Adotou-se, portanto, uma visão formalista, que privilegia a análise de critérios de market share em detrimento de aspectos substanciais do relacionamento entre as partes contratantes. Assim, se, de um lado, a Lei ${ }^{\circ}$ 12.529/2011 tinha abandonado os critérios de notificação baseados em participação de mercado da Lei $\mathrm{n}^{\circ}$. 8.884/94, que causavam incertezas, de outro, a Resolução CADE nº 10/2014 os ressuscitou ao fazer referência à participação no mercado relevante como parâmetro de notificação de "contratos associativos" (EDAP, 2014).

Algumas críticas são feitas com relação a esse critério. Com relação aos contratos em que as partes são horizontalmente relacionadas no seu objeto, entende-se que a interdependência entre duas empresas concorrentes não tem relação com suas participações , "mas sim com a importância relativa do objeto do contrato para cada uma delas em termos de faturamento, quantidade vendida ou capacidade de produção, por exemplo". Já no caso de contratos em que as partes sejam verticalmente relacionadas, a questão relevante é o grau de fechamento. A resolução, ao estabelecer como critério de notificação a participação de mercado de "pelo menos uma" das partes contratantes acaba por criar "condições para a ocorrência de falsos positivos: uma empresa com 30\% de participação em seu mercado é obrigada a notificar contratos, cujo objeto (quantidade envolvida) representa, digamos, apenas 1\% do mercado total" (EDAP, 2014).

Diante desse cenário, mais adequado seria a interpretação da Resolução $\mathrm{n}^{\mathrm{o}}$. 10/2014 sob uma perspectiva sistemática. Nesse sentido, somente deveriam ser notificados aqueles contratos em que, embora as partes preencham os critérios de market share disposto na lei, resultem em uma efetiva cooperação ou compartilhamento de risco que acarretam relação de interdependência entre as partes. Neste caso, o papel das partes na interpretação dos contratos que deverão ser notificados é mais amplo na medida em que a avaliação preliminar acerca da natureza associativa do contrato à luz da legislação concorrencial e da jurisprudência do CADE caberá a elas.

De qualquer maneira e independentemente das críticas feitas à Resolução, fato é que haverá casos em que contratos de licenciamento de direitos de PI deverão ser notificados ao CADE. 


\subsubsection{Notificação de contratos de licenciamento de marca}

Os contratos de licenciamento de marca, que também podem vir acompanhados de acordos de comercialização do produto sob a(s) marca(s) objeto do contrato, permitem que o licenciado se beneficie do poder de marketing ligado à marca licenciada e à sua reputação, o que lhe possibilita obter o poder de mercado associado ao produto sob aquela marca.

Embora nem todos os contratos de licenciamento de marca tenham natureza concentracionista, é possível encontrar exemplos em que esta característica está presente, sobretudo quando o arranjo contratual envolva o acesso pela licenciada a informações comerciais sensíveis da licenciante, tais como sua política de marketing, política comercial e mesmo segredos industriais, em um contexto em que as partes contratantes são concorrentes. Sob essa perspectiva, é possível inferir a natureza cooperativa do contrato que implica uma relação de interdependência entre as partes, nos termos da Resolução n ${ }^{\circ}$. 10/2014 do CADE.

A título ilustrativo, cabe mencionar o contrato de licenciamento celebrado entre concorrentes no mercado de isotônicos, a PepsiCo, Inc. e a Companhia Brasileira de Bebidas - CBB (caso Pepsico / CBB), no qual esta última se obrigava a fabricar, comercializar e distribuir o produto "Gatorade" em todo o território nacional. A CBB já comercializava outra importante marca de isotônico - "Marathon" - e a operação resultaria em uma concentração de mais de 90\% (BRASIL, 2004a). A operação também envolvia a transferência de unidade fabril da Pepsico para a CBB para a produção do Gatorade.

Embora não houvesse muitos detalhes sobre a dinâmica do contrato nos votos, é possível inferir que a CBB teria acesso a informações sensíveis acerca do Gatorade tais como a fórmula do produto. Ademais, dado que a CBB seria responsável pela comercialização do produto no Brasil, também teria acesso a informações comercialmente sensíveis, o que impactaria na concorrência no mercado de isotônicos. Dado o efeito da operação sobre este mercado, o CADE impôs condições à aprovação da operação que envolviam (a) a alienação da marca "Marathon" pela CBB e (b) compartilhamento da rede de distribuição da CBB com a adquirente da marca por um prazo de 6 meses, se assim esta optasse (BRASIL, 2004a). 
Diante desse exemplo e à luz das regras dispostas na Resolução nº 10/2014, conclui-se que a notificação de contratos de licenciamento de marca não pode ser afastada a priori do controle preventivo de atos de concentração. Há situações em que, de fato, o contrato de licenciamento supera a natureza originalmente comutativa e adquire um viés de verdadeiro contrato de cooperação entre as partes, devendo, pois, ser submetido à análise da autoridade concorrencial.

\subsection{Definição de mercado de produtos diferenciados}

\subsubsection{Considerações iniciais}

Os direitos de propriedade industrial, no caso em questão, as marcas, são de extrema relevância para a análise antitruste e, portanto, para verificação do poder de mercado das partes envolvidas.

A marca tem consequência direta na definição do mercado relevante na medida em que, ao trazer atributos especiais aos produtos, acaba por distanciar bens que seriam funcionalmente idênticos. O problema que se apresenta, nesse sentido, é como definir mercados onde os produtos são diferenciados.

A análise antitruste, desde os seus primórdios no final do século XIX com a edição do Sherman Act nos EUA, sempre veio acompanhada da noção de mercado (EVANS, 2010). Seja em casos de atos de concentração seja em casos de condutas, a delimitação de um mercado, isto é, de um espaço dentro do qual agentes econômicos concorrem, sempre precedeu a análise antitruste, para a qual é importante estabelecer se determinada firma ou conjunto de firmas tem ou não poder de mercado.

Porque nasceu no final do século XIX, o direito antitruste se deparou, em um primeiro momento, com uma realidade em que os produtos eram majoritariamente homogêneos. A marca e a propaganda enquanto instrumento de diferenciação entre os bens ainda não eram regra.

Embora as marcas no século XIX tenham começado a florescer e a representar um sinal de qualidade e de origem, elas não tinham a relevância e a função que têm hoje: não faziam parte do cotidiano das pessoas, não buscavam criar um 
vínculo emocional com o consumidor por meio da promoção de atributos reais ou abstratos (percepções) de um produto, criando assim uma preferência, e ainda não estavam arraigadas na estratégia comercial das empresas.

Nesse sentido, a definição de mercado no direito antitruste remonta à época de concorrência entre bens percebidos como intercambiáveis e, em regra, perfeitamente substituíveis entre si. $^{72}$ Atualmente, todavia, os produtos e as marcas estão muito mais diferenciados. ${ }^{73}$

Entretanto, os tribunais ainda encontram muita dificuldade para identificação e delimitação de mercados diferenciados. Essa dificuldade, todavia, é natural. Com tantas variedades de produtos com os mais diversos atributos, não é tarefa simples entender o grau de concorrência, por exemplo, entre Pepsi e Coca-Cola, entre Coca-Cola e H2O, entre um tablet e um laptop.

Os guias de análise de concentração, em geral, trazem uma fórmula padrão, uma espécie de passo-a-passo para a análise de concentrações, que consiste em etapas a partir das quais os efeitos da operação serão analisados.

A delimitação do mercado relevante é como organizar uma pequena caixa onde dentro estarão os produtos que são considerados como concorrentes efetivos e, fora, estará o "resto", totalmente desconsiderado nas etapas seguintes de análise do ato de concentração. ${ }^{74}$

Para produtos homogêneos não é problemático saber o que é o mercado, pois todos os produtos são iguais (ex. trigo). Esses mercados são definidos pelos preços

\footnotetext{
${ }^{72}$ Segundo Lemley e Mckenna (2012, p. 2081), “Antitrust market definition hearkens back to the days of readily interchangeable commodities, like grain or plywood. Buyers might (or might not) distinguish between qualities of grain or plywood, but they are unlikely to pay substantially more for grain merely because it comes from Zachy's Farms rather than Acme Plants. Products and brands today, however, are far more significantly differentiated".

${ }^{73}$ Para utilizar o conceito de Church e Ware (2000, p. 368), por diferenciado entende-se que "(...) the products of differentiated firms are not identical: consumers can and do distinguish between the products of different sellers. However, differentiated products are also similar: they are viewed by consumers as substitutable, usually because they are functionally interchangeable. While the products are differentiated their purpose and use is the same".

74 Segundo o Guia para Análise Econômica de Atos de Concentração, "a definição de um mercado relevante é o processo de identificação do conjunto de agentes econômicos, consumidores e produtores, que efetivamente limitam as decisões referentes a preços e quantidades da empresa resultante da operação. Dentro dos limites de um mercado, a reação dos consumidores e produtores a mudanças nos preços relativos - o grau de substituição entre os produtos ou fontes de produtores - é maior do que fora destes limites. O teste do "monopolista hipotético" (...) é o instrumental analítico utilizado para se aferir o grau de substitutibilidade entre bens ou serviços e, como tal, para a definição do mercado relevante" (BRASIL, 2001).
} 
de arbitragem. ${ }^{75}$ Os preços tendem a convergir para um preço único - Lei do Preço Único. Do contrário, o consumidor compraria o produto numa região x e o revenderia na região y por um preço maior, obtendo lucro certo.

No caso do produto diferenciado, no entanto, o produtor tenta dar traços e atributos distintos ao seu produto de forma a criar uma nova categoria ou subcategoria de produto, diferente, seja de forma substancial, seja de maneira artificial, daquele que seria sua concorrência ordinária.

A questão que se verá, portanto, é que em mercados diferenciados, os produtos não são perfeitamente substitutos, mas sim substitutos imperfeitos concorrendo em um contínuo.

Dessa maneira, obedecer a fronteiras rígidas de delimitação de mercado relevante não é a melhor alternativa.

A definição muito estreita de um mercado relevante pode levar as autoridades a encontrar poder de mercado onde não há por excluir do escopo do mercado produtos que também competiriam entre si em certo grau.

As autoridades antitruste têm lidado com esse problema de diversas formas. Como será explicitado abaixo, decisões norte-americanas inspiraram a noção de submercado, que foi posteriormente bastante criticada por gerar definições exageradamente restritas que supervalorizavam o poder de mercado de uma firma.

Em contraponto à ideia de submercado, tem sido sugerida uma flexibilização da rígida definição de mercado relevante em produtos diferenciados. Embora se reconheça que a identificação do mercado é um importante passo na análise antitruste, para produtos heterogêneos, a definição não pode ser realizada a mão de ferro.

Em vez de se tirar conclusões precipitadas acerca dos níveis de participações de mercado das partes, deve-se buscar fazer uma análise sobre os efeitos da operação nos preços dos produtos e outros fatores que influenciem o bem-estar do consumidor (EVANS, 2010).

75 A arbitragem espacial se dá por intermédio de arbitradores que garantem que a diferença entre os preços de bens homogêneos em duas regiões é consequência, no máximo, do custo de transferência do bem da região de menor preço para a região de maior preço. A Lei do Preço Único, por sua vez, postula que bens homogêneos obedecem à regra da perfeita arbitragem (SANTOS et al., 2007).. 


\subsubsection{Análise da concorrência entre produtos diferenciados}

Para entender o grau de competição entre produtos diferenciados, é adequado valer-se de um instrumento econômico bastante útil - as elasticidades, em especial, a elasticidade-preço do produto e a elasticidade-preço cruzada da demanda entre dois ou mais produtos.

A elasticidade-preço específica de um dado produto mede a variação na quantidade de vendas desse produto quando há um aumento de $1 \%$ (um por cento) no seu preço. A elasticidade-preço cruzada da demanda, por sua vez, refere-se à variação percentual da quantidade demandada de uma mercadoria que resultará no aumento de um ponto percentual no preço de outra (PINDYCK; RUBINFELD, 2010).

Ao medir as elasticidades no caso de produtos diferenciados, encontra-se um contínuo de substituição, isto é, produtos mais ou menos substituíveis entre si. Dessa maneira, percebe-se que a definição de mercado não é automática.

A depender dos atributos dos produtos, o aumento de preço de um produto A pode fazer com que consumidores migrem para outro produto $\mathrm{B}$ e $\mathrm{C}$, mas se houver um aumento no produto $\mathrm{B}$, a migração pode ocorrer para os produtos A e D.

David Evans, em seu artigo "Lightening Up on Market Definition" (2010), traz uma figura muito elucidativa para demonstrar que não existe "a" definição de mercado, mas sim várias possibilidades.

Para tanto, considera um conjunto de produtos com dois atributos (ex. duração da bateria e resolução da tela) que são medidos pelos eixos horizontal e vertical da Figura 3.1 abaixo. O preço, por sua vez, é medido pelo tamanho da bolha. Os produtos têm preços maiores ou menores, mas oferecem diferentes combinações dos atributos. No exemplo, os consumidores não têm preferências uniformes sobre o valor dos atributos de maneira que não faz sentido delimitar o mercado de forma rigorosa. 


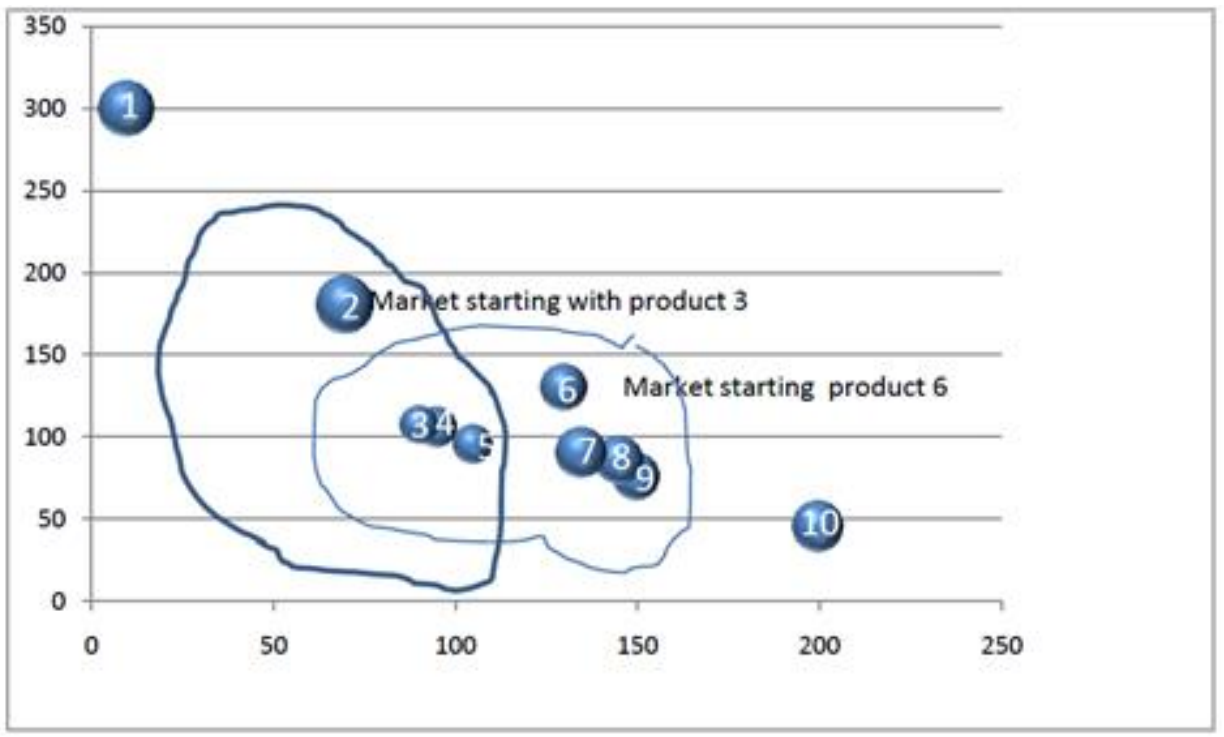

Figura 3.1 - Definição de mercado para um grupo de produtos diferenciados (EVANS, 2010).

Fazer um recorte de mercado, portanto, é um exercício que pode trazer resultados perigosos. Pode-se definir um mercado de forma demasiadamente ampla, sem prestar atenção às peculiaridades e pressões competitivas entre categorias específicas de produtos, ou, ainda, pode-se definir um mercado de forma restrita demais, bloqueando uma operação ou impondo-se restrições estruturais ou comportamentais desnecessárias.

Ademais, o tradicional teste do monopolista hipotético ${ }^{76}$ não ilumina a definição de mercado em produtos diferenciados, uma vez que um "pequeno porém significativo e não transitório" aumento de preços, geralmente calculado com base em supostos aumentos de 5-10\% nos preços do produto, tendem a não ser adequados, tendo em vista que, no contexto de um mercado diferenciado, produtos podem ser substitutos próximos ainda que o aumento de $10 \%$ no preço de um produto A não gere migração para um produto $\mathrm{B}$, apenas acréscimos percentuais superiores de preço. Isso porque a racionalidade em mercados diferenciados é criar uma lealdade tal no consumidor que a firma possa cobrar preços monopolísticos.

Nesse sentido, o uso das elasticidades é mais apropriado quando se pensa em verificar o grau de competição entre um conjunto de produtos. Segundo Lemley e Mckenna (2012, p. 2083-2084):

\footnotetext{
${ }^{76}$ Segundo o teste do monopolista hipotético, o mercado relevante é definido como o menor grupo de produtos e a menor área geográfica necessários para que um suposto monopolista esteja em condições de impor um "pequeno porém significativo e não transitório" aumento de preços (BRASIL, 2001).
} 


\begin{abstract}
"It might seem odd to say that two functionally identical products are in separate markets. But that is because markets aren't always about function; consumers' beliefs about products can drive purchasing behavior even if those beliefs are not based in reality. (...) IP rights can create their own antitrust market in any product in which consumer loyalty to the brand is strong enough, or in which IP rights make the products different enough".
\end{abstract}

O problema da identificação de mercados, portanto, não é trivial. Ferramentas econômicas podem ser utilizadas para elucidar hipóteses e melhor informar o órgão decisório. Porém, nem sempre dados de preços estarão disponíveis para cálculo de elasticidades; ainda que estejam, a definição do mercado vai exigir um corte que não deixa de ter certo grau de discricionariedade $;^{77}$ e as informações fornecidas nunca são (totalmente) neutras. Ademais, o processo administrativo antitruste ou judicial tem um prazo, de maneira que o tempo para colher informações é escasso e o julgador deve decidir com aquelas informações limitadas constantes no processo.

Trata-se do problema denominado por Baker e Bresnahan (2006, p. 4) de “informação local”. Para os autores, a informação é local pela óbvia razão que o processo em qualquer investigação ou caso é necessariamente limitado em escopo. Os litigantes não têm nem tempo nem recursos infinitos para colher informações. Ademais, a informação também é local por uma razão mais sutil: porque inferências sobre conceitos econômicos como poder de mercado ou eficiências quantitativas ou qualitativas nunca são feitas dentro de um vácuo.

Tendo em vista essas dificuldades de obtenção de informações precisas, é importante utilizar-se de todos os dados disponíveis, sejam eles qualitativos sejam quantitativos (BAKER; BRESNAHAM, 2006). ${ }^{78}$ Nesse sentido, vale não só dados de preço para cálculo de elasticidade, mas também outras informações sobre

\footnotetext{
${ }^{77}$ Conforme ensina Maisel (1983, p. 49), "While the correct approach to defining the relevant product market is easy to state, focusing as it does solely on cross-elasticity of demand, it is often very difficult to apply in practice. Courts are usually confronted with a continuum, running from close and obvious substitutes, to less good substitutes, to distant ones. They are required to draw a line somewhere on that continuum separating those substitutes that effectively limit the pricing freedom of the target companies from those that do not. The ultimate choice will often be somewhat arbitrary, and there may be little useful information available to guide the court in making its decision".

${ }^{78}$ Ainda segundo os autores, “ (...) courts must decide antitrust cases reasonably expeditiously, for good public policy reasons, which sometimes constrains the amount of information and especially data available for analysis. This makes the use of multiple sources of evidence particularly valuable" (BAKER; BRESNAHAM, 2006, p. 15).
} 
comportamento do consumidor. Importante notar, todavia, que dependendo do tipo de indústria de que se trate, um tipo de dado pode ser mais adequado que outro.

Diante dessas questões, importante analisar como tem sido enfrentada a questão de definição de mercados diferenciados.

\subsubsection{Definição de produtos diferenciados: conceito de submercado}

Uma das maneiras com que as autoridades têm lidado com a definição de mercado no caso de produtos diferenciados é por meio da utilização do conceito de "submercado" 79 .

Essa noção foi desenvolvida, pela primeira vez, em Brown Shoe (EUA, 1962). Nesse caso, que tratava da união de dois produtores de calçados, Brown Shoe e Kinney, a Suprema Corte considerou a possibilidade de que um mercado amplo contivesse submercados que seriam tratados como mercados distintos para fins concorrenciais. Estas seriam situações em que um grupo particular de consumidores teria dificuldade de trocar determinado produto por alternativas ou nas quais uma firma conseguiria discriminar preços com relação àquele grupo de consumidores (EVANS, 2010).

A Suprema Corte apresentou uma lista de sete "indícios práticos" para uso na definição de submercados: reconhecimento da indústria ou reconhecimento público de um submercado como uma entidade econômica separada, características e usos peculiares do produto, plantas produtivas únicas, sensibilidade a mudanças de preço e estabelecimentos de venda especializados ${ }^{80}$. Esta concepção de definição de

\footnotetext{
${ }^{79}$ Segundo Lemley e Mckenna (2012, p. 2100), "Courts and agencies have tried various workarounds to classic market definition, perhaps in implicit recognition of the problems with existing rules. For instance, agencies and courts sometimes define 'submarkets' within an antitrust market. Alternatively, they speak of the 'smallest relevant market' that meets the SSNIP test".

${ }^{80}$ Nas palavras do Chief Justice Warren, "The outer boundaries of a product market are determined by the reasonable interchangeability of use or the cross-elasticity of demand between the product itself and substitutes for it. [Footnote 42] However, within this broad market, well defined submarkets may exist which, in themselves, constitute product markets for antitrust purposes. United States v. E.I. du Pont de Nemours \& Co., 353 U. S. 586, 353 U. S. 593-595. The boundaries of such a submarket may be determined by examining such practical indicia as industry or public recognition of the submarket as a separate economic entity, the product's peculiar characteristics and uses, unique production facilities, distinct customers, distinct prices, sensitivity to price changes, and specialized vendors. [Footnote 43] Because $\S 7$ of the Clayton Act prohibits any merger which may substantially lessen competition "in any line of commerce" (emphasis supplied), it is necessary to examine the effects of a merger in each such
} 
mercados trouxe muito confusão em casos posteriores e foi muito criticada pela doutrina. $^{81}$

Apesar disso, a ideia ressuscitou, em 2008, com o voto do juiz Brown no caso Whole Foods (EUA, 2008b), que tratava da aquisição pela Whole Foods de um concorrente que também atuava no segmento de mercados orgânicos, a Wild Oats. A corte distrital entendeu que a operação não gerava preocupações concorrenciais, pois supermercados orgânicos premium (premium natural organic supermarkets - PNOS) competiam com supermercados tradicionais e, nesse sentido, as partes envolvidas teriam uma parcela de mercado pequena.

Por outro lado, a corte de apelação considerou que a corte distrital errou na sua definição de mercado por não levar em consideração aqueles consumidores leais aos produtos orgânicos premium, ainda que as partes envolvidas concorressem dentro de um mercado mais amplo.

O Juiz Brown estabeleceu uma distinção entre os chamados "consumidores marginais" e os consumidores leais ou "core customers", segundo a decisão.

Os primeiros seriam aqueles que estariam dispostos a mudar para uma firma $\mathrm{Y}$ diante de um aumento de preços dos produtos da firma $\mathrm{X}$. Os consumidores leais, por sua vez, são aqueles que não trocariam de firmas, ainda que diante de um aumento de preços.

A questão estaria no custo incorrido pela firma caso decidisse aumentar o preço. Se, ao fazer um balanço, o decréscimo de vendas resultante da perda de consumidores marginais ainda compensasse diante das vendas a preços majorados para consumidores leais, então o aumento de preço das firmas seria lucrativo.

O outro lado da moeda está no fato de a firma conseguir praticar preços de monopólio em relação aos consumidores leais, que, em determinados casos, não têm acesso a produtos alternativos. Esta seria a preocupação central do juiz Brown e também a razão por decidir pela segmentação do mercado. ${ }^{82}$

economically significant submarket to determine if there is a reasonable probability that the merger will substantially lessen competition" (EUA, 1962).

${ }^{81}$ Vide Maisel (1983); Pitofsky (1990); Areeda e Hovenkamp (2008).

82 "In appropriate circumstances, core customers can be a proper subject of antitrust concern. In particular, when one or a few firms differentiate themselves by offering a particular package of goods or 
Para ele, os consumidores leais fariam parte de um submercado mesmo sem uma diferença extrema na elasticidade da demanda, uma vez que o mercado é, em última instância, definido pelas preferências consagradas dos consumidores.

A ideia de "submercados", todavia, acabou gerando distorções ${ }^{83}$ na medida em que valorizou determinados aspectos dos produtos e/ou serviço (conforme listados acima) em detrimento da análise da elasticidade-preço cruzada da demanda. No caso Brown Shoe, embora o tribunal tenha reconhecido a importância da mensuração da elasticidade cruzada para fins da análise antitruste, foi além, listando outros fatores que acabam por excluir produtos que exercem pressões competitivas relevantes e representam substitutos efetivos sobre o produto definido de forma restrita.

Em Whole Foods (EUA, 2008b), a análise de que os consumidores de produtos orgânicos premium eram realmente cativos e não teriam opções razoáveis caso a fusão ocorresse parece carecer de uma análise mais profunda, fundamentada em dados de mercado e pesquisas sobre comportamento dos consumidores, e ainda na verificação de se outros supermercados, ainda que não atuantes nesse nicho, teriam incentivos para entrar nesse segmento.

services, it is quite possible for there to be a central group of customers for whom 'only [that package] will do.' United States v. Grinnell Corp., 384 U.S. 563, 574, 86 S.Ct. 1698, 16 L.Ed.2d 778 (1966); see also United States v. Phillipsburg Nat'l Bank \& Trust Co., 399 U.S. 350, 360, 90 S.Ct. 2035, 26 L.Ed.2d 658 (1970) ('It is the cluster of products and services ... that as a matter of trade reality makes commercial banking a distinct' market.). What motivates antitrust concern for such customers is the possibility that 'fringe competition' for individual products within a package may not protect customers who need the whole package from market power exercised by a sole supplier of the package. Grinnell, 384 U.S. at 574, 86 S.Ct. 1698. Such customers may be captive to the sole supplier, which can then, by means of price discrimination, extract monopoly profits from them while competing for the business of marginal customers. Cf. Md. People's Counsel v. FERC, 761 F.2d 780, 786-87 (D.C.Cir.1985) (allowing natural gas pipelines to charge higher prices to captive customers would be anticompetitive). Not that prices that segregate core from marginal consumers are in themselves anticompetitive; such pricing simply indicates the existence of a submarket of core customers, operating in parallel with the broader market but featuring a different demand curve. See United States v. Rockford Mem'l Corp., 898 F.2d 1278, 1284 (7th Cir.1990). Sometimes, for some customers a package provides 'access to certain products or services that would otherwise be unavailable to them.' Phillipsburg Nat'l Bank \& Trust, 399 U.S. at 360, 90 S.Ct. 2035. Because the core customers require the whole package, they respond differently to price increases from marginal customers who may obtain portions of the package elsewhere" (EUA, 1962).

${ }^{83}$ Para Maisel (1983, p. 40), "Several of the Brown Shoe indicia were ill-chosen and have been applied by many courts mechanically, as if by rote, resulting in more indefensible decisions and additional confusion". 
Assim, verifica-se que o conceito de submercado pode gerar definições demasiadamente restritas que não consideram as pressões competitivas de outros produtos participantes do mercado mais amplo e também de outros fatores ${ }^{84}$.

Importante ainda mencionar que o conceito de submercado definido por referência a uma lista de fatores em Brown Shoe nunca teve qualquer justificativa teórica. Ao comentar o caso, Pitofsky (1990, p. 1814-1815) menciona que:

\begin{abstract}
"Instead of directly addressing the question of how to reconcile concern for competitive opportunities of captive user subclasses with the perception that market power does not exist if significant numbers of precarious users will react to a price rise by shifting to substitute products, the Court simply listed a roster of factors to determine discrete markets (...)".
\end{abstract}

Em outras palavras, critica-se o fato do tribunal ter, em grande medida, desconsiderado a metodologia da elasticidade da demanda para adotar outros critérios ${ }^{85}$ sem qualquer embasamento teórico. Ademais, não se buscou analisar como os consumidores marginais reagiriam frente a um aumento de preços e de que forma sua reação poderia proteger os interesses dos consumidores cativos. Isso porque se um grande número de consumidores marginais passa a comprar um bem y diante de um aumento de preços do bem $x$, e, caso haja um número pequeno de consumidores cativos do bem $x$, então, em tese, o fornecedor do bem $x$ não teria incentivos para aumentar $\mathrm{o}$ preço deste produto, haja vista que boa parte da demanda se desviaria e ele não conseguiria obter lucros extraordinários.

Nesse sentido, defender a existência de um submercado distinto com base apenas na existência de diferentes grupos de consumidores é complicado, tendo em vista que é necessário analisar o comportamento dos consumidores marginais e dos consumidores leais.

\footnotetext{
${ }^{84}$ Nesse sentido, Areeda e Hovenkamp (2008, p. 167) afirmam que "Speaking of 'submarkets' merely confuses the issue (...) A typical result of the confusion is an overly narrow market designation that exaggerates the defendant's power.".

${ }^{85}$ Pitofsky (1990, p. 1817) manifesta-se no sentido de que "Virtually all courts started with the Cellophane cross-elasticity of demand test, seeking to determine the extent to which buyers would switch to or from other suppliers given significant price changes. An unfortunate tendency developed to rely on the Brown Shoe roster of factors rather than on the underlying supply and demand elasticities the factors were supposed to address. This approach produced frequent errors. In merger enforcement particularly, there was a free and easy tendency in the cases to carve out scores and even hundreds of submarkets, often turning on little more than the preferences of small classes of buyers".
} 
Dessa maneira, o autor explica que sempre haverá diferentes classes de consumidores com fortes preferências por produtos fisicamente distintos; todavia, inferir da existência dessas diferentes classes que cada uma deva ter a "proteção" de um mercado relevante distinto acaba por resultar num exagero grosseiro do poder de mercado do fornecedor.

Pitofsky (1990) ainda critica o fato dos fatores listados em Brown Shoe não estarem ordenados segundo uma ordem de importância. Isso gera um grande problema na medida em que sinaliza para as autoridades que a escolha de apenas alguns dos fatores listados já poderia caracterizar um mercado único, o que geraria definições de mercados errôneas e demasiadamente estreitas.

Para ele, enquanto elementos tais como características e usos peculiares do produto e preços distintos são indicativos de uma separação de mercados, fatores ligados à existência de grupos específicos, como visto acima, são problemáticos. Ademais, o reconhecimento da indústria ou do público de que haveria um segmento separado nada diria de efetivo sobre o real comportamento dos consumidores diante de aumentos de preços. ${ }^{86}$

Como demonstrado, a definição de mercado de acordo com submercados gerou fortes reações de modo que novas maneiras de se lidar com o problema começaram a ser pensadas.

Recentemente, há uma tendência por parte de diversos autores de defenderem uma flexibilização da definição de mercado. Ademais, os EUA sinalizaram uma flexibilização da análise de mercado relevante ao mencionar em seu Horizontal Merger Guidelines que "The measurement of market shares and market concentration is

\footnotetext{
86 "Several of these factors are derived from the analytical approach in Cellophane, in which the majority stressed factors like peculiar characteristics and uses and distinct prices. Other factors, such as whether there are distinct customers, are problematic. The question should not be whether customers are 'distinct,' but rather whether they are in a position to switch to substitutes, or whether their interests are protected by other customers who will switch. / Still other factors seem decidedly marginal on the question of market definition, such as whether the industry or the public recognizes the submarket as separate-presumably because there is a separate trade association, newsletter, or Standard Industrial Classification (SIC) code. Such formalistic factors are not responsive to the question of whether buyers will switch in response to a substantial price change. / This factor list, like many others in antitrust law, is presented without any indication of priority or weight to specific factors and it unquestionably has worked a good deal of mischief in relevant market definition in merger cases. Without a guiding theory, some courts and enforcement agencies have been attracted to the idea that if three factors pointed to a submarket and only one or two in the other direction, a submarket definition was justified. / Of course, if the two factors that pointed toward a broader market were production substitutability and sensitivity to price changes - more accurate indicators of supply or demand elasticity than other factors - narrow market definitions would be inappropriate" (PITOFSKY, 1990, p. 1815),
} 
not an end in itself, but is useful to the extent it illuminates the merger's likely competitive effects" e "Relevant markets need not have precise metes and bounds" (EUA, 2010).

Todavia, a prática antitruste até o momento tem confiado muito em dados de market share e feito diversas presunções a partir deles, ${ }^{87}$ o que, de certa maneira, impede que se analise a questão de uma forma mais aberta à consideração de outros fatores relevantes, além de criar um ônus pesado às partes que se encontram defronte a tais definições rígidas.

Por esse motivo, apresentam-se algumas soluções apontadas pela doutrina para flexibilizar a higidez até então adotada, o que se passa a analisar a seguir.

\subsubsection{Flexibilização da definição de mercado}

(i) Fatores de submercados

Uma das propostas de flexibilização da definição de mercado relevante em produtos diferenciados foi sugerida por Maisel (1983).

Embora o autor entenda que a definição com base em submercados não tenha lugar na análise antitruste, para ele, há espaço para o que denomina de "fatores de submercado" - diferenças físicas entre produtos e diferenças em como os produtos são fabricados, vendidos, percebidos e usados.

O exame desses fatores de submercado pode ajudar as autoridades a entender a interação entre os diferentes produtos e a dinâmica do mercado. A ideia não é excluir produtos do mercado como se faria num recorte rígido, mas sim analisar diversos cenários e verificar em que medida os produtos concorrem. Para o autor, o que é preciso:

“(...) is a more flexible approach to dealing with product differentiation within the relevant market, a more flexible way of

87 No Brasil, há uma presunção relativa de poder de mercado quando a empresa tem apenas $20 \%$ do mercado relevante, nos termos do Artigo 36, § 2º da Lei nº ${ }^{\circ}$, $2.529 / 2012$. 
refining the analysis to take account of how directly target products confront each other and their principal competitors. One approach would be to use 'submarkets' in a manner completely different from that contemplated by the Court in Brown Shoe. In merger cases, for example, a court could obtain a clearer picture of how directly two competitors confront each other within the overall relevant market by calculating market shares in various submarkets. If the merging firms each had high market shares both in the overall relevant market and in a separable submarket, the court would know that they are direct competitors. Calculating market shares in a succession of overlapping markets might be likened to taking a series of snapshots from different distances in order to provide the viewer with more complete knowledge of the terrain. In close cases, the additional information provided by those snapshots might be useful in interpreting the market share data calculated in the overall market" (MAISEL, 1983, p. 53).

Verifica-se, assim, uma tentativa de abrir caminhos para que a análise de mercado não seja tão rígida e abarque a verificação de diferentes cenários, de maneira a diminuir distorções na delimitação do mercado relevante e evitar erros com consequências indesejáveis.

\section{Análise das Pressões Competitivas}

Outra maneira de encarar a flexibilização da definição do mercado é concentrar-se na análise das "pressões competitivas" a que as firmas estão sujeitas de maneira a avaliar seu poder de mercado. Definir de forma rígida o mercado, como visto, não é um método confiável de analisar a extensão das pressões competitivas ou o grau de poder de mercado (EVANS, 2010).

Ademais, segundo Evans (2010, p. 16), a definição de mercado relevante conduzida atualmente fornece uma visão distorcida e limitada das pressões competitivas. A delimitação do mercado é feita sobretudo com base na substitutibilidade pelo lado da demanda, que, embora seja uma pressão competitiva importante, não é a única. 
Pressão competitiva é "any factor that tends to reduce the expected profit that a firm can earn from taking some action that would harm consumers" (EVANS, 2010, p. 9). Engloba não só a substitutibilidade pelo lado da demanda, como visto, mas também a substitutibilidade pelo lado da oferta, a análise de incentivos à entrada de outras empresas, efeitos de rede, existência de um mercado de dois lados, produtos complementares, dentre outros fatores.

A questão principal, segundo Evans, é que essa análise deve ser feita logo no início, dentro da etapa referente à definição do mercado. Do contrário, rígidas presunções podem ser criadas de maneira a impedir uma análise mais completa nas etapas seguintes, o que poderia conduzir a erros na mensuração do poder de mercado. Nas palavras do autor:

"This approach to market definition is much broader, and more tied to assessing competitive constraints, than is the current approach. The U.S. Department of Justice/FTC Horizontal Merger Guidelines, for example, only consider demand-side substitution in the analysis of market definition. Other factors, such as product repositioning and entry, are considered mainly in assessing competitive effects. This approach, to the extent it is followed, has the effect of setting up a presumption that the chosen market defines the arena of competition and the main sources of competitive constraints. It can, in practice, shift the burden to the merging parties to demonstrate that constraints beyond demand-side substitutability are important. (...) While in principle these other factors could be raised at other points in the analysis the hard market boundaries chosen have the effect of setting up presumptions for the remainder of the case" (EVANS, 2010, p. 33).

O que se quer dizer com isso é que não é uma definição arbitrária de mercado que deve estabelecer quais os fatores de competição serão analisados posteriormente. Ao contrário, todos esses fatores devem ser analisados desde o princípio para que se possa antever qual é o cenário de competição enfrentado pelas firmas do mercado.

Essa metodologia é mais consistente com a atual realidade de produtos eminentemente diferenciados, sem mencionar diversos produtos tecnológicos que refletem mercados de dois lados e apresentam efeitos de rede. 
A definição rígida de mercado com produtos heterogêneos não consegue alcançar a complexidade das interações concorrenciais entre esses produtos de maneira que é preciso adotar-se um método que seja mais abrangente, sem perder de vista a importância dessa etapa para qualquer análise antitruste.

A seguir, a prática do CADE é analisada a fim de verificar se ela é consistente com o desenvolvimento da doutrina acerca do tema.

\subsubsection{Análise de produtos diferenciados pelo CADE}

No Brasil, a definição de mercados diferenciados com base na noção de submercado foi criticada no voto da então Conselheira Relatora Lúcia Helena Salgado em Colgate/Kolynos (BRASIL, 1996b).

Apesar de reconhecer que nesse tipo de mercado os produtos das empresas são substitutos imperfeitos, ${ }^{88}$ a então Conselheira preferiu não segmentar o mercado relevante, criticando a noção de submercado. Segundo ela, seria adequado calcular a elasticidade-cruzada entre os produtos premium, de massa e medicinais. Porém, não havia dados suficientes e a instabilidade de preços (inflação) certamente atrapalharia os resultados.

Mais tarde, a noção de submercados foi retomada, não nos moldes do caso Brown Shoe (EUA, 1962), mas sim sob uma perspectiva mais ampla de análise de interação entre a franja do mercado e o segmento de marca. Nesse sentido, percebe-se que os conselheiros não definem uma fronteira rígida de mercado, analisando os diversos níveis de concorrência entre os submercados e os efeitos dela decorrentes.

Em NRC/Real Comércio (BRASIL, 2008c), ato de concentração relativo a duas concorrentes atuantes no segmento de refrigerantes, analisou-se o mercado sob duas perspectivas: de um lado, um mercado amplo (refrigerantes em geral) e, de outro, um mercado segmentado em refrigerantes de marca e tubaínas.

\footnotetext{
88 "Em casos envolvendo firmas que concorrem por meio de diferenciação, o esforço das empresas é tornar seus produtos tão distanciados dos outros dentro do espaço de produto, a ponto de formarem mercados cativos. Os produtos deixam de ser substitutos perfeitos entre si. Nessas condições a competição pode ser segmentada, com os produtos competindo mais diretamente com aqueles que vendem produtos mais próximos" (BRASIL, 1996a, p. 61).
} 
Como a operação envolvia a compra de ativos de produção de uma firma de tubaínas por outra fabricante de refrigerantes de marca, levantaram-se preocupações com os efeitos de exclusão do concorrente na franja. De acordo com o voto, a franja tem uma dupla função: (i) contenção dos preços no segmento premium e (ii) servir de plataforma para a consolidação da marca e surgimento de novo agente (maverick) apto a competir no segmento premium. A primeira função dependeria, essencialmente, da influência coletiva que o segmento inferior exerce sobre os preços no segmento superior.

Também no caso Atacadão/Korcula (BRASIL, 2008a) realizou-se o mesmo tipo de análise. Estudou-se o mercado de supermercado como um todo e também o mercado de supermercados e hipermercados (submercado premium), de um lado, e de "atacarejo" (franja), de outro.

O voto do então Conselheiro Relator Ragazzo revela que ele procedeu:

“adicionalmente à análise em submercados, à tradicional e conjunta avaliação da atuação dos agentes no mercado mais amplo de super e hipermercados primeiro, porque a análise em submercados não prescinde da análise paralela do mercado mais amplo; segundo, em função de a análise em submercados estar ainda em estágio de amadurecimento pelo Conselho" (BRASIL, 2008a).

A ideia era verificar a efetividade da concorrência entre atores que possuem públicos-alvo distintos e, mesmo entre si, não se vislumbram como concorrentes diretos, porém não necessariamente estavam em mercados distintos. Nos termos do voto do Conselheiro Relator:

"Variações significativas de preços entre produtos funcionalmente fungíveis provavelmente não implicam a delimitação de mercados relevantes distintos, mas, ao sugerirem níveis menores de elasticidade cruzada, apontam, por subsequente, para uma pressão competitiva menor que aquela exercida por produtos com relação aos quais o grau de substituibilidade é maior" (BRASIL, 2008).

Outros atos de concentração posteriores trazem essa mesma metodologia. ${ }^{89}$

\footnotetext{
${ }^{89}$ Recofarma/Leão Júnior (BRASIL, 2009a).
} 
Por fim, interessante ressaltar que votos de Conselheiros do CADE reconhecem a dificuldade de se aplicar a metodologia tradicional de definição de mercado no caso de produtos diferenciados.

Nesse ponto, cabe citar o voto do então Conselheiro Relator Miguel Barrionuevo no ato de concentração envolvendo um contrato de licenciamento no qual a CBB iria engarrafar, comercializar e distribuir com exclusividade, no Brasil, o Gatorade (Pepsico/CBB):

"O objetivo visado pela diferenciação de produto é o de criar agrupamentos de consumidores dispostos a pagar um preço maior para exercer sua preferência por uma determinada marca. Como resultado da diferenciação, cada firma se depara com uma curva de demanda levemente inclinada para a esquerda (negativamente inclinada), que lhe permite cobrar um preço acima do seu custo marginal. Nestas condições, a delimitação do grau de substituição entre um e outro produto torna-se mais difícil para a autoridade antitruste, já que a depender do grau de importância conferida pelo consumidor ao exercício da sua preferência pode estar determinando uma descontinuidade na cadeia de substituição do segmento composto de produtos diferenciados.

A diferenciação, a princípio, beneficia o consumidor, ao tornar disponível uma maior variedade de produtos e estimular investimentos em inovação. Em contrapartida, porém, pode facilitar o exercício de poder de mercado, na medida em que o ofertante do produto diferenciado consiga praticar um preço substancialmente acima do seu custo marginal e dos preços dos demais produtos situados na mesma cadeia de substituição, beneficiando-se, de fato, de uma condição de monopólio localizado.

Desse modo, a definição tradicional de mercado relevante, ou seja, o teste do monopolista hipotético, encontra dificuldade para sua aplicação em mercados diferenciados. Os problemas derivam da necessidade de se precisar, com base em dados econômicos confiáveis, as fronteiras dos mercados, sem perder de vista a ocorrência de concorrência localizada, dentro do espectro dos produtos diferenciados. Desse modo, a definição do produto relevante, para efeito da análise dos impactos competitivos de condutas ou de 
atos de concentração em mercados diferenciados, deve levar em conta, além de todas as informações quantitativas disponíveis, também indícios de que as empresas envolvidas dispõem de poder de mercado para fixar preços de monopólio em nichos localizados" (BRASIL, 2004a, p. 3).

Diante disso, verifica-se que a autoridade concorrencial brasileira tem enfrentado a questão da definição de mercados diferenciados com maior flexibilidade e abertura à experimentação.

Todavia, ainda é grande a importância que se dá a presunções derivadas de dados de market share e, sobretudo, ainda é corrente a delimitação de mercado relevante pautada principalmente na substitutibilidade pelo lado da demanda, sem considerar os outros fatores de pressão competitiva mencionados acima.

Como ressaltado, contudo, a definição errônea ou inapropriada do mercado relevante pode resultar em uma análise antitruste que subestima ou supervaloriza o poder de mercado dos agentes econômicos, o que pode levar a uma interpretação equivocada sobre os efeitos de um ato de concentração. Isso é preocupante do ponto de vista jurídico na medida em que pode resultar na inadequação e desproporcionalidade da decisão da autoridade concorrencial sobre uma dada operação.

Ademais, é a partir da definição do mercado relevante que serão analisados os fatores que afetam a probabilidade de exercício unilateral de poder de mercado, dentre eles, importações, barreiras à entrada, efetividade de rivalidade e outros fatores que favorecem a coordenação de decisões (BRASIL, 2001). Delimitação inadequada do mercado relevante, portanto, também afeta a análise da probabilidade de poder de mercado, onde as marcas também exercem um papel fundamental.

Com efeito, além de ser importante na definição do mercado relevante, o papel da marca é crucial na etapa de análise da probabilidade de exercício de poder de mercado por parte dos agentes econômicos no contexto de um ato de concentração, sobretudo na medida em que representa uma barreira à entrada e também influencia na análise de rivalidade entre as firmas. É o que se verá no item que se segue. 


\subsection{Análise das marcas no exame de probabilidade de exercício de poder de mercado: barreiras à entrada e rivalidade}

\subsubsection{Aspectos teóricos sobre barreiras à entrada}

É ponto pacífico na doutrina econômica que a existência de barreiras à entrada em um dado mercado relevante contribui para o exercício unilateral ou coordenado de poder de mercado na medida em que elas diminuem a concorrência potencial. Ainda, segunda a doutrina da concorrência potencial, barreiras à entrada e elevados custos de saída tornam a concorrência potencial ineficaz para afetar as estratégias das firmas estabelecidas (BAUMOL, ${ }^{90}$ 1982, apud, FARINA; AZEVEDO, 2003), o que fortalece a possibilidade de exercício de poder de mercado.

Em contrapartida, se o mercado é caracterizado por baixas barreiras, não haverá preocupações concorrenciais, pois, assim que uma empresa ou grupo de empresas resolvesse elevar preços para níveis de monopólio, novos competidores apareceriam para contestar o poder de mercado desse agente. Dessa maneira, em mercados em que as barreiras são inexistentes ou baixas, as condições estruturais de mercado não permitem o surgimento de preços de monopólio (FAGUNDES; PONDÉ, 1998, p. 15).

Neste contexto, a análise de barreiras à entrada é um elemento crucial para a determinação dos potenciais efeitos anticompetitivos decorrentes de um ato de concentração. A entrada é uma "reposta natural do mercado a lucros excessivos". Em sendo fáceis as condições de entrada no mercado, a necessidade de ação antitruste é reduzida (GEROSKI ${ }^{91}$, 1988, apud, FAGUNDES; PONDÉ, 1998). Do contrário, a intervenção antitruste poderá ser intensa, a depender do caso.

Explicam Fagundes e Pondé (1998) que o exame das barreiras à entrada com a finalidade de identificar e avaliar os determinantes do desempenho de uma indústria foi originalmente desenvolvido por Joe Bain nos anos 50, cujos trabalhos culminaram na construção do paradigma Estrutura-Conduta-Desempenho (ECD).

\footnotetext{
${ }^{90}$ Baulmol, W., Panzar, J.C. \& Willig, R.D.. Contestable Markets and the Theory of Industry Structure. San Diego: Harcourt Brace Jovanovich, 1982.

${ }^{91}$ P. Geroski. Competition Policy and the Structure-Performance Paradigm. In: S. Davies e B. Lyons (eds.). Economics of Industrial Organization. Surveys in Economics. London : Longman; cap. 5, 1988.
} 
De forma resumida, modelos ECD buscam "derivar de características da estrutura de mercado conclusões acerca de seu desempenho em termos de alguma variável escolhida, supondo para isso que as condutas das empresas são fortemente condicionadas pelos parâmetros estruturais vigentes". Com isso, objetiva-se identificar aqueles fatores estruturais que podem resultar em elevações abusivas das margens de lucro e prejuízos para os consumidores (FAGUNDES; PONDÉ, 1998, p. 2).

Dentre esses fatores estruturais, que são estáveis e não podem ser alterados facilmente, estariam as barreiras à entrada que, para Bain, representam as vantagens que as empresas já estabelecidas no mercado têm sobre concorrentes potenciais $^{92}$. Nesse contexto, quanto maior a intensidade das barreiras à entrada, maior seria o indicador de poder de mercado das empresas oligopolistas.

\subsubsection{Barreiras à entrada baseadas na diferenciação de produto: marca $\mathrm{e}$ investimentos em publicidade}

(i)

\section{Marca}

A marca exerce papel central no contexto das barreiras à entrada assentadas na diferenciação de produto, caracterizadas por aqueles "elementos que fazem com que os consumidores considerem mais vantajoso adquirir um produto de empresas já existentes do que similares oferecidos por concorrentes" (FAGUNDES; PONDÉ, 1998, p. 5). ${ }^{93}$

\footnotetext{
92 Essa definição influenciou o conceito de barreiras à entrada no Guia Brasileiro de Análise de Concentrações Horizontais (SEAE, 2001), que estabelece que "barreiras à entrada podem ser definidas como qualquer fator em um mercado que ponha um potencial competidor eficiente em desvantagem com relação aos agentes econômicos estabelecidos".

${ }^{93}$ Fagundes e Pondé (1998, p. 5-6) identificam 6 fatores que intensificam as barreiras relacionadas à diferenciação do produto: “(i) o controle do acesso à tecnologia necessária para projetar produtos por parte das firmas existentes através de mecanismos legais de controle da propriedade industrial, segredos industriais ou presença de conhecimentos tácitos difíceis de serem imitados; (ii) o montante de gastos com propaganda e vendas requeridos para garantir a fidelidade dos consumidores, impondo aos novos concorrentes despesas elevadas para tornar o seu produto conhecido e aceito no mercado; (iii) a durabilidade e complexidade dos produtos, que tornam a reputação destes decisiva na decisão de compra dos consumidores e fazem com que um novo concorrente tenha que incorrer em gastos elevados durante um período considerável de tempo para convencer o consumidor das qualidades do seu produto; (iv) a presença de práticas e de canais de distribuição que limitam a utilização de determinadas formas de acesso ao consumidor para novos concorrentes, como por exemplo contratos de exclusividade com
} 
De fato, a marca, conforme já visto, é um importante instrumento de fidelização dos consumidores e, nesse sentido, num mercado diferenciado, a entrada de concorrentes implica custos adicionais consistentes em custos de troca ("switching costs”). A demanda pelos produtos do entrante é composta pelos consumidores das firmas já estabelecidas no mercado e pelos consumidores que ainda não fazem parte do mercado.

Para o primeiro grupo de consumidores, o entrante estará em desvantagem na medida em que não só terá de investir em publicidade para fazer frente a empresas já estabelecidas no mercado como terá de oferecer um desconto ou um benefício adicional para convencer esse grupo de consumidores a pagarem o custo de troca do produto (SALGADO, 2006). Esses custos de troca são tão mais altos quanto mais o mercado associe marca a prestígio (consumo conspícuo).

Ademais, a depender do tipo de produto, os custos de troca também serão mais baixos ou mais altos. Para "bens de experiência", que são bens de baixo valor e reduzido custo de experimentação, "o custo em que um consumidor incorre para testar um produto novo ou fora de seus hábitos é igual ao preço do bem”. Dessa maneira, “a lealdade do consumidor à marca é tênue e a capacidade de ocupação de mercado relativamente mais dependente da veiculação de informação sobre qualidade do que da construção de imagem" (SALGADO, 2006, p. 13).

Para "bens de reputação", a assimetria de informação entre o consumidor e o produtor é acentuada e o consumidor não tem condições de avaliar a qualidade do produto a não ser por características superficiais. Nesses casos, a construção da imagem do produto pelo produtor é fundamental e o custo de troca pode ser maior (SALGADO, 2006, p. 13).

Investimentos em publicidade

Além do custo de troca, em mercados diferenciados, conforme já dito, o investimento em publicidade é fundamental para que as empresas possam fazer frente à concorrência. Sem publicidade, a marca praticamente não tem visibilidade. Custos com 
publicidade tradicionalmente são apontados pela doutrina econômica como custos irrecuperáveis incorridos com o objetivo de aumentar a predisposição do consumidor a pagar pelo produto de determinada empresa (SUTTON, 1996).

Esses custos são endógenos na medida em que são variáveis de escolha das empresas, que decidirão qual o nível estão dispostas a investir (SUTTON, 1996) e "através de seus próprios investimentos em marca podem influenciar o nível de investimento de consciência em marca que as rivais têm de alcançar para se tornar competitivas" (BESANKO et al., 2007, p. 246). Nessa linha, explicam Farina e Azevedo (2003, p. 140) que "o elevado e contínuo investimento em diferenciação do produto cria fortes marcas nacionais que estabelecem o montante mínimo de investimento em marca para que novas empresas entrem no mercado".

Naturalmente, as barreiras relacionadas a investimentos em publicidade tenderão a ser menores para empresas que atuem em setores correlatos (e.g. empresa detentora da marca Nivea, famosa por cremes hidratantes, entrando no segmento de protetor solar). No entanto, não deixam de configurar barreiras à entrada.

As barreiras à entrada associadas às marcas e a investimentos em publicidade foram fatores determinantes na imposição de restrições em importantes atos de concentração julgados pelo CADE, por exemplo, nos casos Colgate/Kolynos (BRASIL, 1996b), Sadia/Perdigão (BRASIL, 2011a), dentre outros ${ }^{94}$.

A alta concentração resultante dessas operações associada à dificuldade de contestação das empresas líderes por potenciais entrantes, haja vista a alta fidelidade dos consumidores às marcas detidas pelas empresas envolvidas no ato de concentração e os altos custos irrecuperáveis ligados à publicidade nas marcas no mercado, fizeram com que o CADE determinasse, no caso Colgate/Kolynos (BRASIL, 1996b), a suspensão do uso da marca Kolynos por determinado período de tempo ${ }^{95}$ e, no caso Sadia/Perdigão (BRASIL, 2011a), a alienação de determinadas marcas. ${ }^{96}$

\footnotetext{
${ }_{94}^{94}$ Consituição da Ambev (BRASIL, 2000a), JBS/Rodopa (BRASIL, 2014a), etc..

95 No caso Colgate/Kolynos, ficou registrado que: "no mercado relevante de creme dental, a escala mínima eficiente permite que pequenas empresas entrem no mercado e sobrevivam sem maiores dificuldades, mas elas não contestam o poder de mercado da líder ou das líderes, porque não podem competir em imagem criada pela propaganda. Para ser um competidor à altura e, desse modo, disciplinar o comportamento da líder instalada, é preciso que a empresa atinja uma escala muito superior àquela apresentada pelas empresas que operam na margem do mercado, da ordem, digamos, de 20\%. Assim, conseguiria amortizar os investimentos em propaganda e cobrar preço tão ou mais baixo que a líder" (BRASIL, 1996, p. 81). Diante disso, concluiu-se que: "a natureza da concorrência no mercado de creme dental - por diferenciação de produto - tem na marca a sua principal arma. A concorrência intermarcas,
} 


\subsubsection{Marca na análise de rivalidade entre empresas}

O Guia de Análise de Atos de Concentração Horizontal prescreve que quando as importações não sejam expressivas e a entrada não seja provável, tempestiva e suficiente, a efetividade da competição entre a empresa resultante da operação e os demais concorrentes pode tornar pouco provável o exercício do poder de mercado adquirido (BRASIL, 2001).

A concorrência efetiva entre as empresas é observada em situações nas quais há condutas agressivas por parte dos agentes econômicos para aumentar sua participação de mercado. Em um mercado com alto grau de rivalidade, os agentes econômicos sentem-se ameaçados por seus rivais. Dessa maneira, basta um aumento mínimo de preço por um agente para que os rivais possam aproveitar-se da situação e, consequentemente, o agente perca participação de mercado e lucros.

Por outro lado, quando a marca do produto é o principal fator de decisão do consumidor, a rivalidade entre os produtos poderá ser reduzida, na medida em que parcela significativa dos consumidores considere que suas primeiras e segundas opções de compra estejam concentradas em uma ou um pequeno grupo de empresas e entendam que outros produtos na realidade similares não são substitutos próximos. Nesses casos, a probabilidade de exercício de poder de mercado pela empresa ou empresas que detêm as primeiras opções do consumidor é alta (BRASIL, 2001).

Se uma empresa possui a primeira e a segunda opção do consumidor, dificilmente haverá guerra de preços. Esta empresa se manterá em uma posição estável e não contestada de forma efetiva pela franja do mercado.

por meio da construção da reputação e laços de lealdade com o consumidor é a forma predominante assumida pela concorrência nesse mercado. De todo o exposto ao longo do voto, conlui-se que é o controle simultâneo das duas marcas mais importantes do mercado, em particular da marca dominante KOLYNOS, a barreira à entrada significativa e, por conseguinte, a fonte do poder de mercado agora detido pela adquirente. Assim, é sobre o controle de marcas que deve se concentrar a decisão deste Conselho" (BRASIL, 1996a, p. 109-110).

${ }^{96} \mathrm{O}$ então Conselheiro Ragazzo em seu voto no caso Sadia/Perdigão, ressaltou que: “(...) a marca é um ativo de extrema relevância nos mercados de produtos diferenciados ora analisado, na medida em que é determinante para que os agentes atuantes na indústria conquistem consumidores, que acabam, de certo modo, se fidelizando a determinadas marcas, tornando difícil, e muito, a alteração para marcas de outros rivais, o que demanda custos elevados de propaganda e marketing, normalmente irrecuperáveis. Tais fatores impõem dificuldades à entrada e condicionantes de rivalidade significativos nesses mercados" (BRASIL, 2011a, p. 256-257). 
A análise da rivalidade baseada na diferenciação por marcas foi determinante para o estabelecimento de restrições, pelo $\mathrm{CADE}$, em atos de concentração paradigmáticos tais como constituição da Ambev (BRASIL, 2000a), Sadia/Perdigão (BRASIL, 2011a) e, ainda, JBS/Rodopa (BRASIL, 2014a).

No caso relativo à constituição da Ambev (BRASIL, 2000a), foi constatado que a indústria brasileira de cervejas era caracterizada por "intensa rivalidade entre as empresas e marcas, rivalidade essa que se faz na forma de campanhas publicitárias, disputas de preço e uma ação intensiva sobre os distribuidores" (FARINA; AZEVEDO, 2003, p. 145). Além disso, observou-se relativo baixo nível de fidelidade às marcas e possibilidade de crescimento da participação de mercado de rivais mediante investimentos em publicidade. Diante disso, foi ordenada a venda da marca Bavária, que tinha relativa visibilidade, porém não era uma das principais marcas do portfólio da Ambev.

Em Sadia/Perdigão (BRASIL, 2011a), o CADE observou que a estabilidade das empresas envolvidas como líder e vice-líder incontestáveis do mercado resultaria na ausência de guerras de preço ou atitudes agressivas por parte de concorrentes (BRASIL, 2011a).

No caso JBS/Rodopa (BRASIL, 2014a), que tratava da locação, pela JBS (Friboi) de três unidades de abate e desossa de bovinos de propriedade da Rodopa, o CADE analisou a rivalidade baseada em diferenciação por marca no mercado de carne in natura. Concluiu que a JBS estaria aplicando uma quantidade expressiva de recursos em campanha publicitária, a qual seria responsável por um nível de diferenciação sem precedentes na indústria, que transforma a empresa em uma líder inconteste de mercado. Outras empresas que não investem em marca não são capazes de fazer frente à concorrência da marca Friboi, segundo o Conselho.

A Rodopa tinha algumas marcas que poderiam posicioná-la como um player diferenciado no mercado. No entanto, com a operação, era possível que elas simplesmente desaparecessem do mercado dado que a capacidade produtiva da Rodopa estaria comprometida. Dessa maneira, de forma a possibilitar que um agente de mercado continuasse a investir nessas marcas para fazer frente à estratégia de diferenciação do mercado iniciada pela Friboi, o CADE determinou, como condição à aprovação do ato de concentração, que a Rodopa, dentre outras obrigações, alienasse uma de suas marcas a terceiro (BRASIL, 2014a). 


\subsection{Remédios antitruste envolvendo direitos sobre marca}

\subsubsection{Considerações iniciais sobre remédios antitruste}

A intervenção estatal na livre iniciativa dos agentes econômicos e, como consequência, nos atos de concentração por eles praticados é ampla. Dentro de uma concepção neoliberal na qual o Estado é agente corretor das principais disfunções do mercado e indutor ou fomentador do desenvolvimento, o Direito Econômico atua como um verdadeiro direito da organização dos mercados (NUSDEO, 2014). Nesse contexto, dentro dos limites do art. 174 da Constituição Federal, "o Estado pode regulamentar a atividade privada até o ponto em que essa regulamentação não chegue a caracterizar planejamento econômico" (SALOMÃO FILHO, 2007, p. 377).

No âmbito do controle preventivo, a ideia é proibir aqueles atos de concentração que impliquem eliminação da concorrência em parte substancial de mercado relevante, que possam criar ou reforçar uma posição dominante ou que possam resultar na dominação de mercado relevante de bens ou serviços (art. $88, \S 5^{\circ}$, da Lei no. 12.529/2011). A análise é prospectiva. Com base em um conjunto limitado de informações, a autoridade concorrencial extrai conclusões sobre os efeitos do ato, decidindo por, nos termos do artigo 61 da Lei $\mathrm{n}^{\circ}$. 12.529/2011, “aprová-lo integralmente, rejeitá-lo ou aprová-lo parcialmente, caso em que determinará as restrições que deverão ser observadas como condição para a validade e eficácia do ato".

Diz-se ampla a intervenção porque, no controle estrutural, a autoridade antitruste age com base no princípio da precaução. Embora esse princípio seja tradicionalmente utilizado no contexto das discussões sobre regulação de riscos, sobretudo riscos ambientais e para a saúde, trata-se de uma regra para a tomada de decisões sob "condições de ignorância" (SCHUARTZ, 2007). O princípio da precaução visa à regulação de situações sob as quais não há um domínio seguro de seus efeitos. Em caso de dúvidas ou incertezas, devem-se identificar os riscos e não esperar pelo pior, adotando medidas para que as consequências negativas não ocorram (SARLET; FENSTERSEIFER, 2014).

No caso do CADE, há limitações cognitivas e informacionais da autoridade sobre a operação, os agentes econômicos e o próprio mercado que fazem 
com que suas decisões sejam tomadas sob condições de incertezas (SCHUARTZ, 2007). Ademais, há incertezas até mesmo quanto aos modelos econômicos utilizados para calcular os efeitos esperados do ato. Nesse contexto, a autoridade concorrencial decide com base em "uma atitude conservadora e de aversão ao risco de que concentrações econômicas anticompetitivas venham a ser aprovadas” (BRASIL, 2006, p. 15).

Diante dessa ação cautelosa e conservadora da autoridade concorrencial é que se inserem os remédios estruturais. Eles refletem a prática do CADE na regulamentação dos riscos e incertezas associados às externalidades resultantes das operações entre os agentes econômicos. Nesse campo - ao contrário do campo do controle das condutas, de natureza sancionatória e, portanto, subjugada ao princípio da estrita legalidade - a liberdade da autoridade é maior na regulamentação dos agentes privados. A intervenção é possível mesmo em um cenário de incerteza. ${ }^{97}$

Neste cenário, os remédios estruturais visam restaurar problemas e distorções concorrenciais resultantes da operação notificada, enquanto preservam as eficiências dela decorrentes. Objetivam, "sanar afrontas à livre concorrência, retificar comportamentos, condutas e atos, de forma a preservar a livre concorrência e o mercado, conter abusos de poder econômico (...)" (OLIVEIRA, 2011, p. 19).

Dentre as possíveis restrições aplicáveis pela autoridade antitruste à

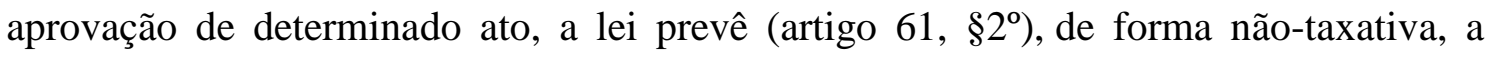
venda de ativos, a cisão de sociedade, a alienação de controle societário, a separação contábil ou jurídica de atividades, o licenciamento compulsório de direitos de PI, dentre outras medidas necessárias à eliminação dos efeitos nocivos à ordem econômica.

\footnotetext{
${ }^{97}$ Explica Schuartz (2007, p. 23) que "[A] idéia de abordar a questão da incerteza nas decisões do CADE em Atos de Concentração recorrendo à máxima "na incerteza, reina o princípio da livre iniciativa, devendo-se aprovar o ato notificado", não alcança a real complexidade do problema. Na verdade, a incerteza quanto à produção de efeitos anticompetitivos por parte de um determinado ato é conceitualmente inseparável dos próprios fundamentos jurídicos desse tipo de regulação, i.e., da restrição jurídica à liberdade de decisão dos agentes econômicos. De fato, a lei de defesa da concorrência é somente uma dentre várias normas jurídicas cuja função é, precisamente, regular incertezas e riscos associados a externalidades produzidas pelas decisões desses agentes. Portanto, tais incertezas e riscos jamais poderiam ser concebidos como se fossem limites dessa regulação. Nesse sentido, pretender enfrentar o problema da incerteza nas avaliações competitivas de atos notificados de acordo com o art. 54 da Lei 8884/94 evocando o princípio da livre iniciativa é colocar a própria questão em termos inadequados, pois o que está em jogo não é a tradicional oposição entre livre iniciativa e regulação, mas o trade-off entre, de um lado, os riscos e incertezas aos quais a regulação visa responder, e, de outro lado, os riscos e incertezas gerados pela própria regulação, sobretudo quando se leva em conta que há nas legislações destinadas ao enfrentamento dos riscos gerados por ações dos agentes econômicos um "viés pró-interesse difuso" na solução desse tipo de trade-off".
} 
Essas medidas são, em geral, classificadas como estruturais ou comportamentais. De acordo com Proença (2011), as medidas estruturais relacionam-se com os ativos das requerentes e envolvem a alienação de determinados bens e direitos, alienação de plantas industriais, vendas de marcas comerciais, etc., ao passo que as medidas comportamentais estão ligadas a obrigações tais como suspensão de cláusulas de exclusividade, abertura de mercados de distribuição ou a garantia de fornecimento de bens e serviços a determinados clientes.

Embora, no Brasil, a maioria dos remédios impostos seja de natureza comportamental (OCDE, 2010) há, via de regra, uma preferência pela aplicação de medidas estruturais, haja vista serem de mais fácil implementação e não necessitarem de monitoramento futuro. De acordo com Mattos (2011), a preferência pelos remédios estruturais está ligada à dicotomia transferência / restrição dos direitos de propriedade. Quando há transferência dos direitos sobre a propriedade, há alteração substancial dos incentivos sobre esses direitos, seja em termos de gerenciamento, decisões de preços, etc. Por outro lado, nos remédios comportamentais, uma vez que não há alteração de propriedade, não há qualquer mudança nos incentivos. Dessa forma, a autoridade concorrencial terá sempre que induzir o proprietário a tomar decisões econômicas que muito provavelmente ele não tomaria na ausência da intervenção.

A imposição de remédios à aprovação de atos de concentração revela uma intervenção do Estado ${ }^{98}$ na liberdade de iniciativa do agente privado, dentre outros direitos. De acordo com Veríssimo (2011):
"A intervenção do órgão antitruste significa, em última análise, a imposição de restrições a direitos constitucionalmente protegidos das firmas envolvidas na fusão, notadamente: (i) seu direito à livre ação no mercado, traduzido, em princípio, no direito à liberdade de iniciativa, com todos os desdobramentos dele decorrentes; (ii) seu direito de contratar, quer no que diz respeito aos contratos que materializam a fusão, quer no que respeita eventuais outros contratos necessários à sua atuação presente ou futura no mercado, e (iii) seu direito de propriedade sobre ativos tangíveis e intangíveis".

\footnotetext{
${ }^{98}$ Para Oliveira (2011), trata-se de uma intervenção indireta do Estado no domínio econômico ou no mercado, uma vez que se dá por meio de normas e não pela atuação como agente econômico (intervenção direta).
} 
Conforme já ressaltado no capítulo anterior, todavia, o princípio da livre iniciativa e os direitos de contratar e de propriedade não são absolutos.

A livre iniciativa, fundamento da ordem econômica brasileira, deve ser balanceada com outros princípios, dentre eles, o da livre concorrência, no qual se insere a repressão ao abuso do poder econômico. Da mesma forma, a liberdade de contratar, que está inserida na liberdade de iniciativa, e o direito de propriedade estão sujeitos a diversas condicionantes constitucionais.

Dessa maneira, tem a autoridade concorrencial legitimidade para realizar essa intervenção no mercado, devendo, no entanto, respeitar certas diretrizes fundamentais, dentre elas, o nexo de causalidade entre o risco de dano à concorrência e o ato de concentração, a proporcionalidade da restrição imposta, a transparência das medidas, dentre outras ${ }^{99}$.

Muito embora a intervenção estatal por meio da imposição de restrições à operação seja legítima (desde que não implique planejamento), em casos muitos complexos essa "imposição" é, no mais das vezes, substituída por uma solução negociada, os chamados acordos em controle de concentração (anteriormente denominados termo de compromisso de desempenho, nos termos da Lei $\mathrm{n}^{\mathrm{o}}$. $8.884 / 19944){ }^{100}$

Conforme ensina Proença (2011), ao conferir ao Estado a função de agente normativo e regulador da atividade econômica, a Constituição Federal (artigo 174, caput) não impediu a intervenção governamental no mercado, porém a possibilitou

\footnotetext{
${ }^{99}$ Mattos (2011) aponta 12 (doze) princípios que devem ser considerados quando da elaboração e imposição de remédios concorrenciais. São eles: (i) nexo causal entre o dano à concorrência e o ato de concentração, (ii) os remédios não devem gerar efeito líquido negativo sobre a economia, (iii) os remédios devem ser consistentes com o dano concorrencial gerado pelo ato de concentração, (iv) os remédios devem ser suficientes para endereçar todos os problemas concorrenciais gerados pelo ato de concentração, (v) o ônus gerado às requerentes pela intervenção deve ser proporcional ao dano concorrencial identificado, (vi) o remédio escolhido deve ser a opção menos restritiva ou onerosa (intervenção minimalista) para a parte disponível à agência, (vii) os remédios não podem objetivar regulação ou planejamento setorial, (viii) os efeitos positivos dos remédios devem ter elevada probabilidade de ocorrer, (ix) os remédios devem ser implementáveis do ponto de vista prático, monitoráveis e ainda permitirem à agência garantir o cumprimento pelas requerentes (enforcement). (x) a implementação e o efeito esperado dos remédios deve ocorrer no mais curto período de tempo possível, (xi) os remédios devem ser transparentes e (xii) os remédios não podem criar problemas concorrenciais em outros mercados. Obviamente, ressalta o autor, que geralmente não é possível observar, de forma perfeita, todos esses princípios. No entanto, é necessário observá-los da melhor maneira possível, levando em consideração os inevitáveis trade-offs entre eles.

${ }^{100}$ Nos termos do art. 125 do Regimento Interno do CADE, este "poderá receber propostas de Acordo em Controle de Concentrações (ACC) desde o momento da notificação até 30 (trinta) dias após a impugnação pela SG, sem prejuízo da análise de mérito da operação.”
} 
em moldes indicativos. Nesse sentido, o acordo em controle de concentração surge como um instrumento em que a autoridade e o agente privado cooperam entre si na busca de soluções para viabilizar o negócio de forma que a concorrência seja preservada.

Obviamente, o poder de intervenção da autoridade concorrencial para conformar o ato à livre concorrência prevalece caso não seja atingido nenhum acordo comum entre a autoridade e o particular. Dentro desse contexto, as restrições necessárias à manutenção das condições de concorrência serão impostas à operação e caberá ao agente privado a concretização do ato dentre os moldes definidos pelo CADE ou, então, a desistência.

A prática demonstra que, em geral, há imposição de restrições a atos de concentração sem a adoção de acordos ou mesmo consulta às requerentes em casos mais simples que envolvam, por exemplo, a necessidade de redução do limite temporal ou geográfico de cláusulas de exclusividade.

No entanto, em casos mais complexos, que envolvem desinvestimentos e alienação de direitos, por exemplo, geralmente busca-se uma solução conjunta com as partes envolvidas dentro da ideia de que os remédios não podem implicar regulamentação ou planejamento setorial e de que a sociedade poderá se beneficiar mais de um resultado obtido com a coordenação da Administração e dos administrados, tendo vista a assimetria informacional do Estado frente às requerentes e, ainda, a maior probabilidade de implementação e monitoramento quando o agente econômico expressamente concorda com as restrições.

\subsection{2. $\quad$ Remédios concorrenciais aplicáveis às marcas}

Em muitos casos, os direitos sobre propriedade industrial representam um elemento fundamental da análise do ato de concentração, seja no que se refere à análise do mercado relevante, seja na análise de questões relacionadas à probabilidade de exercício de poder de mercado. Nesse sentido, as restrições recairão sobre eles, especialmente quando tenham impactos substanciais sobre a rivalidade no mercado ou, ainda, representem altas barreiras à entrada. 
Tendo em vista o escopo do presente trabalho, serão analisados apenas os remédios concorrenciais aplicados às marcas. Não serão estudadas as medidas aplicáveis a outros tipos de direitos industriais.

Antes de tratar de cada um desses remédios, é importante mencionar que a classificação rígida entre remédios comportamentais e remédios estruturais não é completamente clara quando se fala em restrições sobre direitos de propriedade industrial. Em geral, essas restrições têm essas duas dimensões de forma que a International Competition Network (2005) classifica o licenciamento de um direito de PI como um "remédio híbrido estrutural/comportamental". De maneira semelhante, a Comissão Europeia (EUROPA, 2005) considera que o compromisso de uma empresa retirar uma marca do mercado de forma a abrir espaço para outros competidores situa-se em uma faixa de fronteira entre o estrutural e o comportamental.

A intervenção antitruste nos direitos de propriedade industrial pode ocorrer de três formas, isto é, por meio da determinação de (i) cessão, (ii) licenciamento ou (iii) suspensão do uso da marca por determinado período (também entendida como retirada da marca do mercado por determinado período).

(i) Cessão

No caso da cessão, uma vez que há transferência definitiva dos direitos e mudança de seu titular (natureza de alienação), pode ser entendida como uma medida estrutural. No entanto, o licenciamento e a suspensão do uso da marca são, conforme dito assim, remédios híbridos.

(ii) Licenciamento e rebranding

Em relação ao licenciamento, cabe fazer uma distinção entre a licença voluntária e a licença compulsória. No primeiro caso, o agente econômico permite que terceiros explorem economicamente os direitos de propriedade industrial do qual é titular, mediante remuneração e atendimento de certas obrigações estipuladas em um contrato. No caso da licença compulsória, o Estado determina que o agente deve 
licenciar o seu direito, contra a sua vontade, estabelecendo, para tanto, as condições e termos em que isso irá ocorrer.

A licença voluntária é aplicável tanto a marcas quanto a patentes. No entanto, a disciplina da licença compulsória está prevista apenas para as patentes, nos termos dos artigos 68 a 74 da LPI e do Decreto $n^{\circ}$. 3.201/1999, o qual dispõe sobre a concessão, de ofício, de licença compulsória nos casos de emergência nacional e de interesse público que trata $o$ art. 71 da LPI.

Embora o artigo 61, $\S 2^{\circ}$, inciso V, da Lei $\mathrm{n}^{\circ} .12 .529 / 2011$ inclua o licenciamento compulsório de direitos de PI dentre as restrições que poderão ser determinadas pelo CADE para a aprovação de determinado ato, a jurisprudência desse órgão reconheceu que não é sua competência a determinação desse tipo de medida. $\mathrm{O}$ CADE, nesse sentido, no máximo, poderia fazer uma recomendação. ${ }^{101}$

De fato, a licença compulsória tem um caráter repressivo ao titular da patente em virtude de abuso dos direitos dela decorrentes, abuso do poder econômico, não exploração ou comercialização insatisfatória às necessidades do mercado (artigo 68 da Lei de Propriedade Intelectual). Ainda, pode ser concedida em casos de emergência nacional ou interesse público (artigo 71 da Lei de Propriedade Industrial) ou nos casos de dependência (artigo 70 da Lei de Propriedade Industrial).

Verifica-se, portanto, que as hipóteses legais de licença compulsória são taxativas, do que se depreende que devem ser interpretadas restritivamente, por se tratar de norma que atinge direitos fundamentais. ${ }^{102}$ Dessa forma, não poderiam ser utilizadas como restrições no contexto de atos de concentração, que tampouco têm natureza repressiva, mas sim preventiva.

Por essa razão, o CADE, caso entenda que uma restrição relacionada ao licenciamento de direitos industriais é necessária, celebra um compromisso com as partes envolvidas para que este tenha caráter voluntário.

Nesses casos, segundo Capucio e Melo (2011), a autoridade antitruste, via de regra, restringe-se a exigir que as condições negociadas sejam compatíveis com aquelas usualmente praticadas no mercado e que não haja discriminação entre

\footnotetext{
${ }^{101}$ Vide caso Pfizer/Wyeth (BRASIL, 2012a).

${ }^{102}$ Nesse sentido é o entendimento da ProCADE caso Pfizer/Wyeth (BRASIL, 2012a).
} 
concorrentes, o que é totalmente diferente da licença compulsória, na qual o Estado determinada as obrigações tais como o valor da remuneração.

Ademais, segundo Mattos (2011, p. 94), uma subespécie de licenciamento seria o rebranding, no qual "o licenciamento da marca seria transitório até que o licenciado, com a reputação emprestada da marca principal seria capaz de construir sua própria marca". Segundo o autor, remédio dessa natureza foi implementado pelo CADE no caso da fusão Merck-Schering-Plough, no qual marcas de medicamentos conhecidos foram licenciadas transitoriamente até que os licenciados fossem capazes de registrar produtos com sua própria marca (BRASIL, 2010b).

(iii) Suspensão do uso da marca por determinado período

Por fim, há também a possibilidade de se exigir a suspensão do uso da marca por determinado período. Esse tipo de remédio foi bastante criticado no estudo da Comissão Europeia (2005) (EUROPA, 2005), pois, se, de um lado, pode abrir espaço para a atuação de concorrentes, por outro, diminui as opções de escolha do consumidor e destrói o valor comercial da marca.

\subsubsection{Análise da efetividade de remédios envolvendo limitações ao direito de marca: $\underline{\text { estudo de casos }}$}

No que tange aos remédios envolvendo direitos de propriedade industrial, geralmente, a limitação imposta pela autoridade concorrencial visa dar acesso a esses direitos a um terceiro, de maneira a reduzir as barreiras à entrada no mercado em resposta a preocupações concorrenciais surgidas em decorrência da concentração.

A experiência do CADE em imposição de restrições envolvendo direitos de marcas de fato demonstra que medidas estruturais (cessão) teriam sido mais eficazes se impostas no lugar de medidas híbridas (licenciamento e suspensão de uso). 
Como, para certos casos, as medidas estruturais foram impostas há alguns anos, é possível observar o comportamento do mercado de forma a avaliar a efetividade da medida.

\section{Caso Colgate/Kolynos}

No caso relativo à aquisição da Kolynos pela Colgate, a concentração de mercado gerada era de, praticamente, $80 \%$, sendo o mercado caracterizado por elevados gastos em publicidade e alto investimento em marca, além de assimetria informacional, uma vez que o consumidor não tinha condições de avaliar a qualidade do produto a não ser por características superficiais de cor, sabor, consistência, etc.

A análise dos efeitos anticompetitivos, no caso, concentrou-se no poder das marcas. Segundo a jurisprudência internacional apresentada pela Conselheira Relatora Lúcia Helena Salgado e Silva, "não é permitido que uma mesma empresa controle duas marcas de posição proeminente no mercado, sobretudo se tais marcas eram anteriormente concorrentes e a incorporação tenha eliminado ou venha a eliminar a concorrência entre elas" (BRASIL, 1996b).

Dessa forma, concluiu a Relatora que "é o controle simultâneo das duas marcas mais importantes do mercado, em particular da marca dominante Kolynos, a barreira à entrada significativa e, por conseguinte, a fonte do poder de mercado agora detido pela adquirente", razão pela qual a decisão concentrou-se sobre o controle das marcas (BRASIL, 1996b).

As restrições impostas pela Relatora envolveram a (a) suspensão da utilização da marca Kolynos em creme dentais no Brasil por 4 anos e (ii) realização de oferta pública para produção por encomenda do creme dental no mesmo segmento então ocupado pela variedade "Super Branco" do creme dental "Kolynos" (limite de 14.000 ton por ano) para concorrentes existentes ou potenciais no mercado brasileiro de creme dental bem como para varejistas e distribuidores de grande porte que pretendam ingressar no mercado através do lançamento de marcas próprias. ${ }^{103}$

\footnotetext{
${ }^{103}$ Há diferença entre os contratos de fornecimento para concorrentes e para varejistas e distribuidores de marcas próprias: no primeiro caso, o comprador deverá fornecer matéria-prima e embalagem, enquanto que, no segundo caso, a própria Kolynos fornecerá matéria-prima e embalagem.
} 
Facultativamente, a Colgate poderia, durante o período de suspensão da marca Kolynos, licenciá-la de forma exclusiva para a constituição de marca dupla, mediante oferta pública e contrato que preveria o desaparecimento gradual (fading out) da marca Kolynos, assim como o oferecimento público, no Brasil, de contratos de fornecimento de tecnologia, com remuneração de acordo com os usos e costumes, para produção de creme dental no segmento Kolynos Super Branco, utilizando carbonato de cálcio precipitado. Entretanto, a empresa não se utilizou de tal faculdade.

Ao verificar-se o que ocorreu no mercado de cremes dentais após a imposição das restrições pelo CADE, é possível, até certo ponto, analisar a sua efetividade. No caso em tela, o CADE basicamente aplicou medidas híbridas suspensão de marca por período delimitado de tempo e obrigação de produção por encomenda.

O que aconteceu, na prática, é que a Colgate, logo após a decisão da autoridade antitruste e da suspensão da então importante marca Kolynos, lançou outra marca com exatamente as mesmas características e estratégias de marketing da Kolynos, conforme ilustrado na Figura 3.2.

O TCD firmado pela Colgate continha obrigação expressa em sua cláusula 3.2 no sentido de que a empresa não poderia usar durante o período de suspensão da marca Kolynos qualquer material de embalagem, propaganda e promoção que contenha o nome Kolynos como marca de creme dental, tampouco qualquer elemento legalmente protegido que possa ser associado pelos consumidores ao creme dental Kolynos de tal forma a resultar na aquisição errônea pelo consumidor médio do creme dental, por tomá-lo pelo creme dental Kolynos. Não obstante, a Procuradoria do CADE, em seu parecer sobre o cumprimento, pela Colgate, das obrigações do TCD entendeu que houve "observância e atendimento satisfatório das condições fixadas no TCD” (BRASIL, 2002, p. 3). 

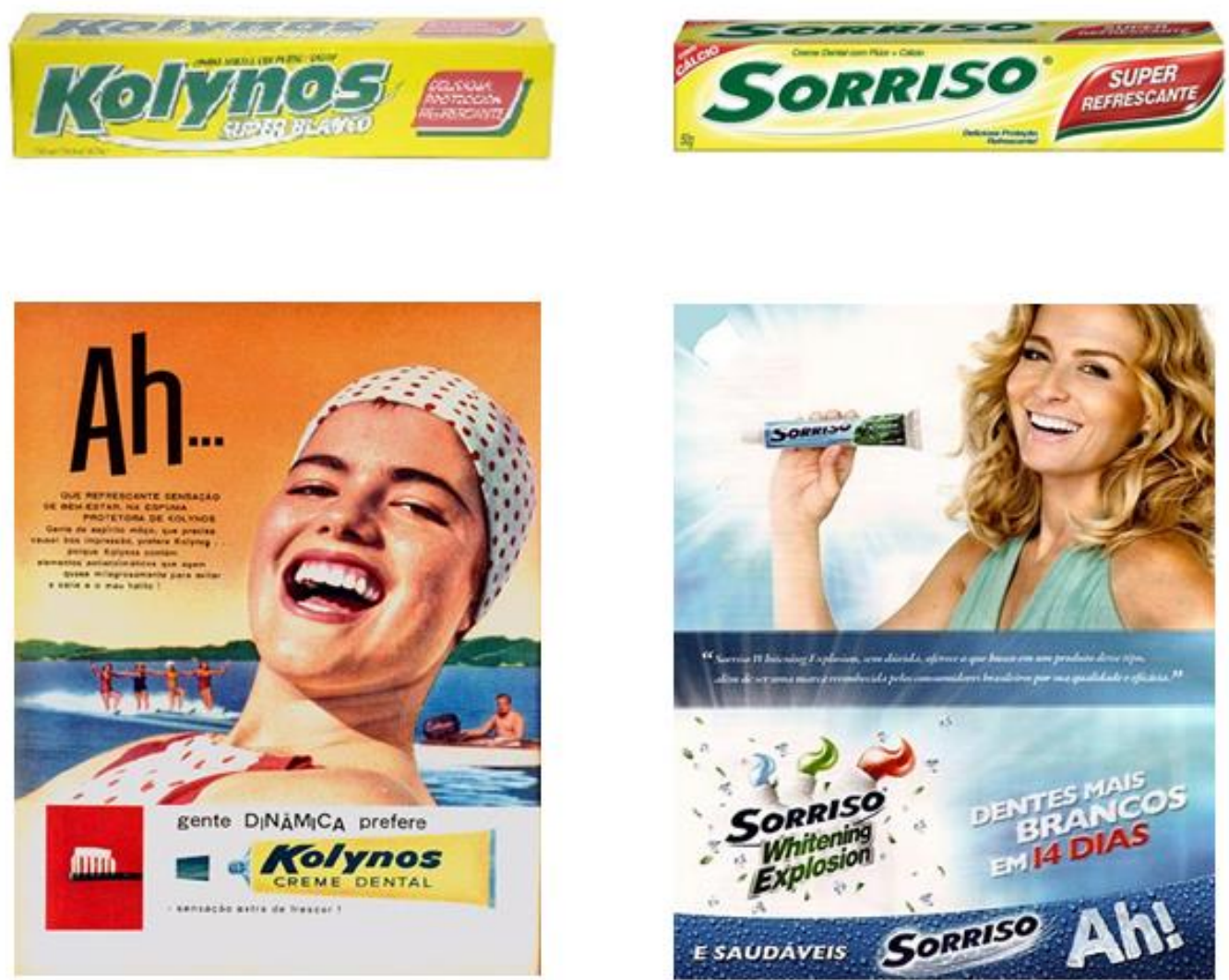

Figura 3.2 - Embalagem e cartazes das marcas Kolynos (esquerda) e Sorriso (direita).

Como a decisão do CADE não impedia a criação de uma segunda marca pela Colgate e a proibição da cláusula 3.2 quanto ao lançamento de novas marcas não era muito restritiva, nada foi feito pelo órgão para impedir a conduta da Colgate no lançamento do creme dental Sorriso.

Está claro, todavia, que o comportamento da Colgate feriu a essência das obrigações impostas pelo CADE.

A ideia de suspender o uso da marca Kolynos e obrigar a Colgate a produzir ou fornecer o mesmo creme dental antes comercializado sob aquela marca para terceiros era criar condições para que um agente já estabelecido no mercado ou um entrante pudesse fazer frente à Colgate, aumentando, assim, o nível de rivalidade no mercado.

No entanto, ao criar a marca Sorriso exatamente nos mesmos moldes da Kolynos, utilizando-se todos aqueles atributos que estavam ligados àquela marca e 
aproveitando-se de sua reputação passada, a Colgate, na prática, reintroduziu a Kolynos no mercado. Nesse sentido, toda a racionalidade da decisão do CADE foi destruída.

Se, por um lado, o administrado tem uma ampla esfera de liberdade, estando obrigado a fazer ou deixar de fazer algo apenas por lei (ou por decisões com força de lei), por outro, ele não pode agir de forma a contornar uma obrigação ou uma proibição se o resultado de sua ação é, na realidade, uma violação à essência daquela obrigação ou proibição.

Em razão do oportunismo do agente econômico em burlar determinadas obrigações impostas pela Administração, as medidas comportamentais exigem constante monitoramento. Do contrário, não serão efetivas e não evitarão que a concentração gere prejuízos à concorrência. De fato, Barrionuevo (2011) afirma que, "no caso Kolynos, faltou maior monitoramento e a venda de ativos para viabilizar algum concorrente".

O CADE deveria ter monitorado as ações de publicidade da Colgate para que elas não mitigassem as restrições impostas pelo CADE.

A despeito disso, em artigo no qual analisou os efeitos da operação, a relatora do caso, Lúcia Helena Salgado, concluiu, após análise de preços do setor e de evolução de participação das empresas, que houve queda de preço real do tubo de creme dental e a líder de mercado havia perdido participação. Ainda, para a relatora:

“(...) conseguiu-se, com a suspensão da marca Kolynos, impedir o exercício de poder de mercado - o que se pode constatar pela evolução dos preços de creme dental após a aquisição e o lançamento de inovações, indisponíveis anteriormente no mercado brasileiro em virtude da ausência de concorrência. Observou-se o surgimento ou expansão de novas categorias de produtos - naturais, gel, branqueadores, terapêuticos e embalagens mais práticas, assim como o crescimento de marcas de baixo preço e marcas próprias" (SALGADO, 2006, p. 31-32).

Atualmente, todavia, Colgate-Palmolive permanece como líder absoluta. Fechou 2010 com 69\% de participação, seguida de Unilever, dona da Close Up, com 19\%, e da P\&G, com 5\% (INSTITUTO DE AÇÃO TECNOLÓGICA E DESENVOLVIMENTO INOVADOR, 2012). O que se pode extrair desses dados de 
participação de mercado é que a Colgate continua à frente de seus concorrentes em termos de participação. Outras empresas têm market shares em níveis bem menores.

Ainda que não se possam extrair conclusões de forma direta e inequívoca sobre os efeitos da decisão do CADE no mercado de cremes dentais, o fato é que ela acabou por não cumprir seus objetivos, e condições estruturais não foram criadas para que um novo agente ou um agente já estabelecido pudesse se desenvolver sem ter de fazer frente a altas barreiras à entrada.

\section{(ii) Caso Sadia/Perdigão}

Considerando a experiência com o caso Colgate/Kolynos (BRASIL, 1996b) e, buscando-se evitar condutas como a criação de novas marcas que pudessem representar barreiras equivalentes àquelas existentes antes da obrigação de suspensão de uso, licenciamento ou venda de determinada marca, o CADE precaveu-se em decisões posteriores. No caso Sadia/Perdigão, foi inserida a obrigação de que as partes não criassem marcas nos mercados em que alguma restrição ao seu uso fosse imposta. Com isso, almejou-se, nos termos do voto-vista do Conselheiro Ricardo Ruiz, impedir que a empresa implementasse uma "estratégia de mimetização criando uma marca com características semelhantes à que foi suspensa" (BRASIL, 2011a).

No que tange às restrições impostas pelo CADE referentes à venda de marcas, percebe-se uma dificuldade de avaliar qual o ativo ou quais ativos devem ser vendidos de maneira que a concentração não tenha o efeito de reduzir ou eliminar a concorrência no mercado.

As medidas estruturais, que exigem desinvestimentos de ativos, devem permitir que o comprador dos ativos aja como concorrente viável. Segundo Barrionuevo (2011), "os problemas com os desinvestimentos ocorrem quando: a) os ativos desinvestidos não geram empresa sustentável; b) existe assimetria de informações entre comprador e vendedor dos ativos; c) eles mantêm relação entre comprador e vendedor (por exemplo, um fornece insumo para o outro)".

Não se tem conhecimento de estudos econômicos que analisaram os efeitos da fusão sobre o mercado. 
No caso relativo à constituição da AMBEV (BRASIL, 2000a), que reuniu sob o mesmo controle acionário a Brahma, sua controlada, a Skol, e a Antarctica, houve críticas à decisão de alienação da marca Bavaria para compradora com menos de $5 \%$ de participação de mercado. Na época, a Bavaria representava apenas cerca de 7\% das vendas de cerveja do mercado e não estava no rol das marcas preferidas pelos consumidores.

Segundo Farina e Azevedo (2003, p. 150), “a decisão do CADE foi relativamente branda, tendo se apoiado na existência de rivalidade no mercado e de eficiências advindas da fusão".

No entanto, a despeito de o mercado ser altamente diferenciado e serem altos os investimentos em publicidade, os consumidores não se mostravam muito leais às marcas, o que teria justificado o CADE ordenar a alienação de uma marca de menor relevância no portfólio da empresa objeto da fusão.

Vale ressaltar que a marca Bavaria perdeu metade do seu market share desde a operação de fusão em 1999 até a efetiva venda à empresa canadense Molson e nos anos que se seguiram permaneceu com pouca representatividade no mercado de cervejas.

De qualquer modo, ao analisar os efeitos da fusão, Farina e Azevedo (2003) ressaltaram as maiores preocupações do SBDC com a fusão, relacionadas ao aumento de preços aos consumidores e à eliminação de concorrentes por meio do uso do portfólio de marcas, não haviam se concretizado. Com efeito, em artigo recente no qual analisou o mercado de cerveja de 1999 a 2011, Farina, Tito e Arashito (2011) concluiram que, depois de mais de 10 anos após a fusão da Ambev, o preço médio real da cerveja diminui e, hoje, a cerveja pilsen é cerca de 10\% mais barata do que em 1999. Além disso, os lucros das empresas cervejeiras têm crescido de forma constante. O volume comercializado também aumentou ao passo que a participação de mercado da Ambev reduziu de 70\% em 1999 para 68\% em 2010. Para os autores, preços menores, lucros maiores e maiores quantidades comercializadas são consistentes com ganhos de eficiências. 
O caso Pepsico/CBB é um bom exemplo de efetividade dos remédios impostos pelo CADE. Trata-se, conforme já ressaltado, de um ato de concentração envolvendo um contrato de licenciamento entre Pepsico e $\mathrm{CBB}$, no qual esta última também fabricaria e venderia isotônicos sob a marca Gatorade no território brasileiro. A CBB, no entanto, já produzia e comercializava no Brasil o isotônico Marathon.

Durante a análise do ato de concentração, o CADE verificou um claro desvio dos investimentos com publicidade da marca Marathon, o que agrava a preocupação antitruste com a possibilidade de eliminação da marca em favor da marca Gatorade, líder do mercado.

Diante desse cenário, o CADE, por maioria, aprovou a operação, nos termos do voto reformulado em plenário pelo então Conselheiro Roberto Pfeiffer e determinou a alienação da marca Marathon, que, na época, era a "única capaz de rivalizar, ao menos em parte, com a líder Gatorade" (BRASIL, 2004a) e representava $17 \%$ das vendas do mercado, contra $77 \%$ do Gatorade. Além disso, foi previsto em TCD que o adquirente teria a opção de adquirir os ativos para a produção do produto e, ainda, utilizar temporariamente a rede de distribuição da CBB.

Após a determinação da autoridade antitruste, a Globalbev (fabricante do Flying Horse) adquiriu a marca Marathon. Atualmente, essa marca permanece em segundo lugar e houve a entrada de novas empresas - Carrefour (linha Taeq), Mormaii, Coca-Cola (Powerade), o que indica que a decisão do Conselho teria cumprido os seus propósitos.

\section{(v) Conclusões sobre restrições envolvendo direitos sobre marca}

Analisando-se as medidas envolvendo restrições ao direito de marca, a alienação parece ser a medida mais efetiva desde que crie condições reais para o desenvolvimento de um concorrente sustentável.

No caso de licenciamento por prazo temporário, contudo, não há racionalidade para o agente licenciado investir em publicidade daquela marca para que, 
depois de findo o prazo estipulado pelo CADE, a marca volte ao licenciante, que usufruirá dos investimentos eventualmente despendidos pelo licenciante. Ademais, ao investir em marca alheia, o licenciante estará fortalecendo, em termos concorrenciais, o licenciador, já que, em última instância, a marca retornará para ele. Este é o problema do licenciamento exposto por Ragazzo no caso Sadia/Perdigão:

"(...) aqui, deve-se falar, efetivamente de alienação, e não de um mero licenciamento temporário de marca (...) não faria sentido que um agente econômico recebesse o mero licenciamento temporário de uma marca, sabendo que teria de investir na publicidade e valorização da mesma, somente para devolvê-la cinco anos depois. Se, por outro lado, não se investisse na marca durante esses cinco anos (ou até mesmo se ela fosse desativada nesse período), haveria uma grande desvalorização desse ativo, o que não seria interessante nem para as empresas nem para o mercado e para os consumidores. Aliás, poderia haver uma mera transferência de demanda para a marca premium remanescente, provocando uma concentração de mercado que ora se busca evitar. Finalmente, essa solução, meramente temporária, implicaria que ao final de 5 anos, retornar-se ia ao cenário competitivo pós-operação com os exatos mesmos problemas que ora se vislumbra. As Requerentes voltariam a ter, definitivamente, essas duas marcas na mão, e o concorrente licenciado não" (BRASIL, 2011a, p. 370).

A suspensão também não parece ser uma alternativa eficiente, já que a marca suspensa tem alta probabilidade de perder seu valor econômico.

Em vista disso, dentre as restrições ao direito de marca, a alienação representa uma solução mais efetiva. No entanto, dada a sua gravidade, é necessário avaliar bem o grau de razoabilidade, proporcionalidade e adequação da medida, sob pena de ferir a liberdade de iniciativa econômica. 


\section{CAPÍTULO 4. MARCAS E O CONTROLE DE CONDUTAS}

\subsection{Introdução}

Ao longo das últimas duas décadas, houve uma profusão de trabalhos sobre a intersecção entre o Direito Antitruste e o Direito da Propriedade Industrial. A maioria deles, no entanto, teve como ponto central de análise a questão das patentes. ${ }^{104}$ As marcas, embora, atualmente representem um dos principais ativos empresariais e, em termos quantitativos, tenham maior circulação no comércio do que as patentes, ${ }^{105}$ receberam pouca atenção da doutrina especializada.

Em que pese haver, atualmente, uma percepção de que as empresas tendem a, cada vez mais, utilizar as marcas como uma barreira estratégica à entrada de concorrentes (OCDE/INNO-TEC, 2009), são poucos os casos de condutas envolvendo direitos marcários que efetivamente chegam à análise das autoridades antitruste.

Desse modo, o presente capítulo tem por objetivo analisar o tratamento dispensado às condutas envolvendo direitos de PI - em especial, as marcas - no âmbito do controle repressivo realizado pela autoridade concorrencial. Busca-se, ainda, um critério objetivo pelo qual seja possível separar as condutas lícitas daquelas ilícitas sem

\footnotetext{
${ }^{104}$ Há uma série de questões que explicam a menor intervenção antitruste em casos envolvendo direito marcário em comparação com as investigações que tratam de patentes e mesmo outros direitos de PI. Em primeiro lugar, questões marcárias geralmente são resolvidas pela disciplina da concorrência desleal. Em muitos casos, a conduta atinge apenas a esfera privada dos agentes econômicos, não representando uma ameaça real à concorrência enquanto instituição. Em segundo lugar, porque as patentes representam um monopólio sobre uma tecnologia e as marcas, a princípio, apenas um direito de exclusividade sobre a utilização de um termo relacionado a um produto ou serviço, a possibilidade de que o direito sobre patente se converta em um monopólio no sentido econômico ou ao menos contribua de forma decisiva para o aumento do poder econômico de seu titular é maior do que no caso da marca (PALLADINO, 1977). Ademais, por representar um monopólio sobre uma tecnologia, podem surgir questões relacionadas à essencialidade de uma patente para desenvolvimento de novos produtos. A questão da dependência de uma patente em relação à outra pode geram questões concorrenciais relevantes. Em terceiro lugar, conforme ressaltado no Capítulo 1, ainda há uma noção generalizada, disseminada pela Escola de Chicago, de que a marca é um instituto eminentemente pró-competitivo, uma vez que permite a diferenciação entre agentes econômicos e, assim, a atração de clientela de acordo com os atributos e qualidades superiores dos produtos ou dos serviços, na linha do que se espera de uma competição baseada em mérito. Em quarto lugar, é possível que haja uma preocupação maior das autoridades antitruste com o impacto das decisões sobre os consumidores. A marca é fundamental para garantir que o consumidor faça uma escolha consciente acerca dos produtos e/ou serviços que deseja consumir. Qualquer intervenção na competição de marcas que alterasse essa função essencial teria efeitos nefastos sobre as relações de consumo.

${ }^{105}$ De acordo com as estatísticas do INPI, em 2012, foram depositadas 150.107 pedidos de registro de marcas e apenas 33.395 pedidos de patentes. No mesmo ano, foram registradas 55.306 marcas e apenas foram concedidas 3.130 patentes (BRASIL, 2013c).
} 
que se mitiguem indevidamente os direitos de PI. Ademais, por uma questão de completude do tema relativo à intersecção entre concorrência e marcas, serão estudadas aquelas condutas que, embora não envolvam um uso direto da marca como instrumento anticompetitivo, com ela guardam relação. Trata-se aqui das condutas que envolvam o uso abusivo da publicidade e das estratégias de marketing que tenham o condão de afetar a concorrência.

Em primeiro lugar, serão feitos alguns breves apontamentos acerca dos elementos que caracterizam uma infração à ordem econômica nos termos da legislação brasileira. Em segundo, será realizada uma análise da metodologia utilizada na Europa, nos EUA e no Brasil para julgamento de violações à concorrência envolvendo o uso de propriedade intelectual e será proposto um critério objetivo para a análise da (i)licitude dessas espécies de condutas. Em terceiro lugar, serão examinadas condutas específicas envolvendo direitos marcários que podem ser passíveis de análise antitruste. Por fim, serão abordadas formas abusivas de uso da publicidade e de estratégias de marketing que podem ter impactos no Direito Antitruste.

\subsection{Estrutura do ilícito antitruste: ato, pressupostos, elemento volitivo e efeitos}

Antes de adentrar na análise específica de condutas envolvendo o uso de direitos de PI e, sobretudo, o uso das marcas, será feita uma breve exposição sobre a estrutura do ilícito antitruste.

O ilícito administrativo concorrencial tem um núcleo central composto pelo ato sob qualquer forma manifestado, que deve ter como pressuposto quaisquer dos fatores identificados nos incisos I a IV do art. 36 da Lei 12.529/2011. Grosso modo, esses pressupostos são verificáveis por meio da análise do objetivo do agente (elemento volitivo) e/ou por meio de seus efeitos (reais ou potenciais) sobre o mercado. Esta é a dicção do art. 36 da Lei 12.529/2011:

“Art. 36. Constituem infração da ordem econômica, independentemente de culpa, os atos sob qualquer forma manifestados, que tenham por objeto ou possam produzir os seguintes efeitos, ainda que não sejam alcançados: 
I - limitar, falsear ou de qualquer forma prejudicar a livre concorrência ou a livre iniciativa;

II - dominar mercado relevante de bens ou serviços;

III - aumentar arbitrariamente os lucros; e

IV - exercer de forma abusiva posição dominante.

$\S 1$ o A conquista de mercado resultante de processo natural fundado na maior eficiência de agente econômico em relação a seus competidores não caracteriza o ilícito previsto no inciso II do caput deste artigo.

$\S 20$ Presume-se posição dominante sempre que uma empresa ou grupo de empresas for capaz de alterar unilateral ou coordenadamente as condições de mercado ou quando controlar $20 \%$ (vinte por cento) ou mais do mercado relevante, podendo este percentual ser alterado pelo Cade para setores específicos da economia.

$[\ldots] . "$

Para entender a estrutura da infração concorrencial, é necessário aprofundar-se em cada um de seus elementos, analisando-os dentro de um contexto amplo do Direito Administrativo Sancionatório e à luz dos dispositivos constitucionais relacionados à ordem econômica, em especial, os artigos $170^{106}$ e $173, \S^{\circ},{ }^{107}$ da Constituição Federal. É o que se discute nos itens que se seguem.

\subsection{1. $\underline{\mathrm{O} \text { ato }}$}

Este primeiro elemento do ilícito concorrencial não enseja muitos debates. De acordo com a legislação antitruste brasileira, não importa o meio ou o mecanismo que o agente econômico ou os agentes econômicos utilizem para atingir

\footnotetext{
106 "Art. 170. A ordem econômica, fundada na valorização do trabalho humano e na livre iniciativa, tem por fim assegurar a todos existência digna, conforme os ditames da justiça social, observados os seguintes princípios: I - soberania nacional; II - propriedade privada; III - função social da propriedade; IV - livre concorrência; V - defesa do consumidor; VI - defesa do meio ambiente, inclusive mediante tratamento diferenciado conforme o impacto ambiental dos produtos e serviços e de seus processos de elaboração e prestação; VII - redução das desigualdades regionais e sociais; VIII - busca do pleno emprego; IX tratamento favorecido para as empresas de pequeno porte constituídas sob as leis brasileiras e que tenham sua sede e administração no País. Parágrafo único. É assegurado a todos o livre exercício de qualquer atividade econômica, independentemente de autorização de órgãos públicos, salvo nos casos previstos em lei."

107 "Art. 173, $\S 4^{\circ}$ - A lei reprimirá o abuso do poder econômico que vise à dominação dos mercados, à eliminação da concorrência e ao aumento arbitrário dos lucros."
} 
quaisquer dos fins dispostos nos incisos do artigo 36. A lei é clara ao utilizar a expressão "atos sob qualquer forma manifestados". Dessa maneira, a princípio, não há atos específicos isentos do controle repressivo de condutas.

\subsection{2. $\quad$ Pressupostos do ato}

Conforme mencionado, para que um ato seja considerado uma violação à legislação concorrencial, é necessário que ele carregue qualquer um dos seguintes pressupostos: (i) limitação, falseamento ou qualquer forma de prejuízo à livre concorrência ou à livre iniciativa; (ii) dominação do mercado relevante de bens ou serviços; (iii) aumento arbitrário dos lucros; e (iv) exercício abusivo de posição dominante. Sem esses fatores, não há qualquer lesão ao bem jurídico a que se visa tutelar pela legislação antitruste (i.e. a concorrência). Cada um deles será melhor explorado abaixo.

(i) Limitação, falseamento ou qualquer forma de prejuízo à livre concorrência ou à livre iniciativa

O inciso I do art. 36 da legislação concorrencial consagra os princípios da livre iniciativa e da livre concorrência tutelados no art. 170 da Constituição Federal (FORGIONI, 2014). Representa, assim, um pressuposto "guarda-chuva" que abarca todos aqueles constantes nos demais incisos do art. 37. Afinal, a tutela da livre concorrência e da livre iniciativa é o objetivo precípuo da legislação antitruste e a justificativa central para atuação do Estado de forma repressiva com o fim de preservar a concorrência saudável entre os agentes econômicos. Não havendo lesão a esses bens jurídicos, não haverá dominação de mercado tampouco abuso de posição dominante.

(ii) Dominação do mercado relevante de bens ou serviços e abuso de posição dominante 
Os incisos II e IV da Lei $\mathrm{n}^{\circ}$. 12.529/2011 são tratados num mesmo tópico, pois o abuso de posição dominante está incluído na prática da dominação de mercado.

Nessa linha, entende Bruna que a legislação concorrencial, ao tratar do abuso de posição dominante, o fez através de "duas disposições redundantes". Para o autor, “[...] não configura ilícito de dominação de mercado relevante a dominação de mercado decorrente de conduta não abusiva. Assim, como se vê, tanto o inciso II quanto o inciso IV incriminam somente o exercício abusivo de posição dominante" (2001, p. 112-113).

$\mathrm{O}$ ato de dominar mercado relevante, contudo, é mais amplo do que o exercício abusivo de poder de mercado. De fato, para que haja um ilícito antitruste é necessário que a dominação do mercado seja precedida de um ato abusivo, mas não necessariamente um abuso de posição dominante. Pode ocorrer dominação de mercado em decorrência de um comportamento colusivo. ${ }^{108}$

O abuso de posição dominante, ao contrário da colusão, refere-se à conduta unilateral que só pode ser praticado por aqueles agentes que, de fato, detêm posição dominante. ${ }^{109}$

A constatação do abuso de posição dominante é precedida por uma análise de desvirtuamento de uma finalidade. ${ }^{110}$ É necessária uma ponderação acerca dos "limites impostos ao exercício da atividade econômica e as responsabilidades sociais dos detentores de poder econômico" (BRUNA, 2001, p. 137). Assim, haverá abuso de posição dominante na medida em que o exercício deste poder pelo agente

\footnotetext{
${ }^{108} \mathrm{Na}$ linha do que ensina Salomão Filho (2007, p. 121-122), “[...] a dominação de mercado haverá toda vez que existir o risco de limitar a concorrência em seu sentido institucional, isto é, reduzir a escolha do consumidor. Isso ocorrerá tanto quando houver risco de exclusão de concorrente ou de colusão entre concorrentes que possa ter impacto sobre o mercado, limitando a escolha do consumidor".

${ }^{109}$ Para averiguar a existência de posição dominante, é necessário analisar se o agente tem o poder de agir de forma indiferente e independente de outros agentes econômicos (FORGIONI, 2014). Bruna (2001, p. 115) sumariza o conceito de posição dominante como "aquela que confira a seu detentor quantidade substancial de poder econômico ou de mercado, a ponto de que possa ele exercer influência determinante sobre a concorrência, principalmente no que se refere ao processo de formação de preços, quer atuando sobre o volume da oferta, quer sobre o da procura, e que lhe proporcione elevado grau de independência em relação aos demais agentes econômicos do mercado relevante".

${ }^{110}$ Há uma análise semelhante ao abuso de direito e desvio de poder. O abuso de direito é analisado segundo a perspectiva da teoria objetivista, para a qual é preciso analisar o caráter antissocial do exercício do direito. Nesse sentido, explica Bruna $(2001$, p. 159) que "há abuso do direito quando o seu exercício conflita com a finalidade social para a qual foi conferido [...]". Já o desvio de poder, conceito de Direito Administrativo configura-se quando o agente pratica um ato visando a fim diverso daquele previsto explicita ou implicitamente na regra de competência (art. $2^{\text {a }}$, parágrafo único, inciso "e" da Lei $\mathrm{n}^{\mathrm{o}}$. 4.717/65).
} 
desvirtue-se do seu destino socialmente útil, que impõe ao seu titular o direito de explorar sua atividade econômica, porém, preservando a concorrência e o mercado.

Essa ideia de abuso quando haja desvirtuamento dos limites dentro dos quais o poder econômico pode agir tem grande influência da jurisprudência europeia. A Corte Europeia, em casos paradigmáticos, adotou o entendimento de que haverá abuso sempre que a empresa com poder econômico recorrer a "métodos diferentes daqueles que regem a concorrência normal". ${ }^{111}$

Dessa maneira, aquelas condutas que fizerem parte do jogo normal da concorrência e que refletirem as práticas de uma concorrência por méritos ("competition on the merits") ${ }^{112}$ não serão punidas pela legislação concorrencial. Conforme previsto no parágrafo $1^{\circ}$ da Lei $\mathrm{n}^{\mathrm{o}}$. 12.529/2011, "a conquista de mercado resultante de processo natural fundado na maior eficiência do agente econômico em relação a seus competidores não caracteriza o ilícito previsto no inciso II do caput deste artigo".

Essa noção de competição por méritos deve estar muito clara e presente na análise de infrações concorrenciais praticadas por titulares de direito de PI. A titularidade de um direito de PI não necessariamente confere ao seu titular um poder de monopólio, mas apenas uma exclusividade sobre o uso daquele direito.

Nesse sentido, deve-se analisar, antes de tudo, se o agente investigado detém posição dominante. A titularidade sobre patentes, desenhos industriais, marcas, dentre outros direitos dessa natureza, poderá contribuir para a posição dominante do agente, mas não necessariamente ser determinante. Averiguada a existência de posição dominante, deve-se analisar se houve abuso do direito de PI detido e, ainda, se houve nexo de causalidade entre este abuso de direito e a restrição à concorrência no mercado. Essas questões, no entanto, serão analisadas com maior profundidade em seção própria.

\footnotetext{
111 "La notion d'exploitation abusive est une notion objective qui vise les comportements d'une entreprise en position dominante qui sont de nature à influencer la structure d'un marché où, à la suite précisément de la présence de l'entreprise en question, le degré de concurrence est déjà affaibli et qui ont pour effet de faire obstacle, par le recours à des moyens différents de ceux qui gouvernent une compétition normale des produits ou services sur la base des prestations des opérateurs économiques, au maintien du degré de concurrence existant encore sur le marché ou au développement de cette concurrence". Conforme Hoffmann-La Roche v. Commission (EUROPA, 2009a) e AKZO v. Commission (EUROPA, 1991).

${ }^{112}$ No mesmo sentido: Irish Sugar v. Commission (EUROPA, 1999); Michelin v. Commission (EUROPA, 2003b); Van den Bergh Foods v. Commission (EUROPA, 2003a); e Microsoft v. Commission (EUROPA, 2007).
} 
O aumento arbitrário dos lucros e a prática de preços excessivos representam duas faces de uma mesma moeda. Em geral, se há um aumento arbitrário de lucros, este decorre da imposição de preços excessivos ao consumidor.

A Lei $n^{\circ}$. 12.529/2011 excluiu o dispositivo da Lei $n^{\circ} .8 .884 / 1994$, que incluía no rol de condutas potencialmente anticompetitivas a imposição de preços excessivos ou o aumento sem justa causa do preço de bens ou serviços. ${ }^{113}$ Paradoxalmente, manteve o aumento arbitrário de lucros como um dos fatores que não podem ser objetivados pelos agentes econômicos, sob pena de prática de infração à ordem econômica, nos termos do inciso III da Lei $\mathrm{n}^{\circ}$. 12.529/2011.

Forgioni (2014) ressalta que a repressão aos lucros arbitrários ou aos preços excessivos, tradicionalmente, tem origem na proteção do consumidor assegurada pela legislação antitruste ao lado da proteção à concorrência. No mesmo sentido, Salomão Filho (2007) explica que a proibição do abuso de preço está historicamente ligada ao caráter protecionista do consumidor em relação ao poder econômico, sob o qual o sistema econômico brasileiro foi formado desde os tempos coloniais.

No entanto, não se consegue conceber que o aumento arbitrário de lucros configure uma infração autônoma, independente, por exemplo, de uma conduta cartelizada ou de uma prática exclusionária derivada de abuso de posição dominante. ${ }^{114}$

A própria Constituição Federal, no parágrafo $4^{\circ}$ do artigo 173 posiciona o aumento arbitrário dos lucros como uma decorrência do abuso do poder econômico: "a lei reprimirá o abuso do poder econômico que vise à dominação dos mercados, à eliminação da concorrência e ao aumento arbitrário dos lucros". Dessa maneira, a existência de um dispositivo legal que disponha de forma autônoma sobre o aumento arbitrário de lucros é ineficaz.

\footnotetext{
${ }^{113}$ Lei $\mathrm{n}^{\circ}$. 8.884/1994: "Art. 21. As seguintes condutas, além de outras, na medida em que configurem hipótese prevista no art. 20 e seus incisos, caracterizam infração da ordem econômica: XXIV - impor preços excessivos, ou aumentar sem justa causa o preço de bem ou serviço" (revogado).

${ }^{114114}$ De fato, explica Salomão Filho, ao tratar da Constituição Federal de 1967, que "o aumento arbitrário dos lucros e a eliminação substancial da concorrência surgiam como meras consequências do ilícito principal e único", que, sob este diploma, era o abuso do poder econômico e a dominação do mercado (2007, p. 107).
} 
Com efeito, defende Salomão Filho que o fato de o abuso de posição dominante (art. 36, IV) e o aumento arbitrário de lucros (art. 36, III) estarem em dispositivos diferentes não significa que o segundo possa ter configuração independente. Para o autor, "arbitrário é só aquele que decorre de abuso de posição dominante" (2007, p. 220). De fato, não faz sentido que um agente sem posição dominante aumente arbitrariamente seus lucros. Ele sequer teria condições fáticas e econômicas para tanto.

Na mesma linha, Ragazzo ao tratar de preços excessivos dispôs que, sendo a conduta decorrência de um cartel ou mesmo de prática exclusionária (e.g. recusa de venda), haveria outros dispositivos na Lei Antitruste que a enquadrariam como ilícita. Assim, não haveria "maior necessidade de encontrar uma solução interpretativa para os dispositivos sobre preços excessivos" (2011, p. 32-33).

É preciso ter em mente que o objetivo precípuo da legislação antitruste é a proteção da concorrência enquanto instituição. A proteção ao consumidor é obtida de forma indireta. Conforme leciona Salomão Filho, "o fato de o consumidor ser o destinatário econômico final das normas concorrenciais não o transforma em destinatário jurídico direto das mencionadas normas" (2007, p. 81).

A norma concorrencial, portanto, não deveria conter dispositivo cujo objetivo precípuo é proteger diretamente o consumidor. Em matéria de práticas ou cláusulas abusivas que exijam do consumidor vantagem manifestamente excessiva ou o coloquem em desvantagem exagerada, já há o CDC para a tutela do consumidor. Estes atos são decorrências diretas do aumento arbitrário de lucro ou preço excessivo.

Dessa maneira, a previsão de um ilícito concorrencial de aumento arbitrário dos lucros totalmente desconectado do abuso de posição dominante parece resultar em bis in idem em virtude dos dispositivos já existentes na legislação consumerista, em especial, os artigos $39, \mathrm{~V},{ }^{115}$ e $51, \mathrm{IV},{ }^{116}$ do CDC.

Por fim, do ponto de vista prático, é muito difícil estipular um critério de aferição de aumento arbitrário de lucros. Conforme lembra Ragazzo (2011, p. 26), em um sistema onde a liberdade de preços é a regra, a definição desse eventual critério

\footnotetext{
115 “Art. 39. É vedado ao fornecedor de produtos ou serviços, dentre outras práticas abusivas: [...]V exigir do consumidor vantagem manifestamente excessiva".

116 “Art. 51. São nulas de pleno direito, entre outras, as cláusulas contratuais relativas ao fornecimento de produtos e serviços que: [...] IV - estabeleçam obrigações consideradas iníquas, abusivas, que coloquem o consumidor em desvantagem exagerada, ou sejam incompatíveis com a boa-fé ou a equidade".
} 
torna-se "verdadeira regulação direta pelo órgão de defesa da concorrência". Ocorre que “a precificação de uma empresa orientada para maximizar lucro é socialmente desejável, na ausência de falhas de mercado que demandem intervenção em preços".

Diante disso, entende-se que o inciso III do art. 36 da Lei $n^{\circ} .12 .529 / 2011$ carece de eficácia.

\subsubsection{Elemento volitivo e efeitos}

O artigo 173, § 4 , da Constituição Federal de 1988 estabelece que "a lei reprimirá o abuso do poder econômico que vise à dominação dos mercados, à eliminação da concorrência e ao aumento arbitrário dos lucros".

Ao comentar o texto da Constituição de 1946, que continha conteúdo similar àquele do atual texto constitucional ${ }^{117}$, Shieber entendeu que o propósito anticompetitivo da conduta deveria estar bem caracterizado para que ela pudesse ser considerada uma infração. Para o autor, a lei não poderia prescindir dos preceitos da Constituição. Uma vez que esta possibilitava a coibição de conduta que tivesse por fim domínio dos mercados nacionais, eliminação da concorrência, ou aumento arbitrário dos lucros, a legislação infraconstitucional baseada nesse dispositivo não deveria extrapolar esse mandato, afastando a finalidade da conduta como elemento de sua ilicitude. Nesse sentido, destacou Schieber que "a aceitação (...) de que o legislador afastou-se das finalidades dos atos ao definir os abusos do poder econômico privará a lei antitruste de sua base no artigo 148 da Constituição (...)” (1966, p. 35).

O artigo 36 da Lei $n^{\circ}$. 12.529/2011, ao regulamentar o artigo $173, \S 4^{\circ}$, da Constituição Federal, reproduziu não apenas elemento intencional da Constituição, mas também positivou o critério de ilicitude baseada nos efeitos: "constituem infração da ordem econômica, independentemente de culpa, os atos sob qualquer forma manifestados, que tenham por objeto ou possam produzir os seguintes efeitos (...)".

Considerando que a legislação antitruste tem como objetivo proteger a concorrência enquanto instituição, não é razoável supor que o elemento intencional

\footnotetext{
${ }^{117}$ CF 1946: "Art 148 - A lei reprimirá toda e qualquer forma de abuso do poder econômico, inclusive as uniões ou agrupamentos de empresas individuais ou sociais, seja qual for a sua natureza, que tenham por fim dominar os mercados nacionais, eliminar a concorrência e aumentar arbitrariamente os lucros."
} 
possa ser analisado isoladamente, sem considerar os possíveis efeitos das condutas sobre o objeto jurídico tutelado. Um dono de uma padaria na Vila Mariana em São Paulo pode até ter a intenção de dominar o mercado relevante de padarias da região, mas sua intenção não tem o condão de produzir qualquer efeito num contexto em que o bairro conta com centenas de padarias e supermercados. É como a intenção de Pink e Cérebro de "dominar o mundo".

Dessa maneira, o elemento intencional ou volitivo não deve ser analisado sob uma perspectiva subjetiva. É necessário analisar o objetivo do agente como um critério de avaliação da potencialidade de produção de efeitos da conduta. Nesse sentido, quando não estiverem presentes evidências robustas de efeitos reais da conduta no mercado, o exame do objetivo do agente, ou, nas palavras de Salomão Filho, do "plano empresarial da sociedade (...) revelado por contratos, atos e reações práticas" (2007, p. 98), pode ser utilizado como um indicativo de que seu ato poderia ter efeitos anticompetitivos.

Naturalmente, para qualquer análise de efeitos, reais ou potenciais, de uma conduta, o exame rigoroso da estrutura de mercado (e.g. poder de mercado dos agentes, condições de entrada, rivalidade) é essencial. Não se pode admitir no ordenamento jurídico brasileiro, a condenação de uma conduta apenas pela intencionalidade do agente sem qualquer análise sobre o seu impacto sobre a concorrência.

O Brasil não admite a per se condemnationem, exigindo a apreciação, caso a caso, dos efeitos potenciais da conduta. ${ }^{118}$ Ao CADE cumpre, em cada processo administrativo, entender primeiro a dinâmica do mercado para avaliar se o acusado (ou acusados) possui efetivamente poder de mercado ou capacidade de dominação do mercado de bens ou serviços. ${ }^{119}$

\footnotetext{
118 "É hoje conclusão pacífica e resultado adquirido do Direito Brasileiro o não-tratamento de qualquer conduta como um ilícito per se. Todas estão sujeitas a algum critério de racionalidade que possa vincular à produção de algum efeito. Essa concepção foi consagrada na lei brasileira pelo correlação necessária imposta pelo art. 20 da lei concorrência brasileira entre as condutas descritas no art. 21 e os efeitos descritos no art. 20" (SALOMÃO FILHO, 2007, p. 263). O CADE acolhe amplamente esse entendimento, já tendo proclamado que "no Direito pátrio não existem condutas consideradas ilícitas per se". Nesse sentido: Cooperativa dos Jornaleiros da Região de Campinas v. Distribuidora Fernando Chinaglia S/A e outros (BRASIL, 2003); SDE v. TAM e outras (BRASIL, 2004b); . SDE v. Santos Brasil S/A - TECON Terminal de Contêineres e outros (BRASIL, 2005b).

119 "Não basta observar uma grande participação percentual na produção total ou comercialização de determinado produto para concluir que o agente tem poder de mercado. Mesmo uma empresa com grande participação nas vendas de determinado produto pode não ter qualquer poder de aumentar os preços.
} 
Sobretudo quando se discute a potencialidade dos efeitos, é necessário que não se banalize o conceito, criando parâmetros tão baixos para sua configuração que, na prática, realiza-se uma condenação per se. O potencial de dano deve ser demonstrado caso a caso pela acusação, não estando a autoridade administrativa autorizada a criar presunções absolutas de prejuízo. Sem isso, não há infração concorrencial.

\section{A Constituição Federal assegura ao acusado - em processo} administrativo ou judicial - o devido processo legal. Além disso, no âmbito dos processos administrativos sancionadores, aos quais se aplicam as mesmas garantias do processo penal $^{120}$ - aplicam-se adicionalmente os princípios da lesividade (ofensividade), e, sobretudo, da presunção de inocência, que condicionam a interpretação e aplicação do artigo 36 da Lei 12.529/2011.

Pelo princípio da presunção da inocência, cabe ao órgão acusador partindo sempre "do pressuposto juspolítico do 'estado de inocência' do cidadão" -

Basta que existam (a) vários substitutos para seu produto ou, então, (b) vários concorrentes prontos a entrar no seu mercado tão logo preços mais elevados tornem maiores as possibilidade de sucesso e de lucro a esse mercado" (SALOMÃO FILHO, 2007, p. 96). Também existe a possibilidade de poder econômico elevado do comprador, que igualmente impede o exercício do mesmo poder pelo vendedor (GOLDBERG, 2006).

${ }^{120}$ A doutrina e jurisprudência são unânimes em reconhecer que os princípios e garantias aplicáveis ao direito penal e direito processual penal são igualmente aplicáveis ao processo administrativo sancionatório. Nesse sentido, ressalta Figueiredo (2006, p. 408) que: "De conseguinte, se estivermos diante de processo revisivo de atos administrativos não punitivos, aplicaremos os princípios do Direito Processual Civil. Porém, se diante quer da aplicação de sanções, quer de revisão de ditas sanções, deveremos aplicar princípios do Direito Penal". Moraes (2009, p. 489) esclarece ainda que o princípio da presunção da inocência vem sendo aplicado em seus vários desdobramentos, notadamente na esfera administrativa sancionadora. Os tribunais superiores também adotam o mesmo posicionamento: "Consoante precisas lições de eminentes doutrinadores e processualistas modernos, à atividade sancionatória ou disciplinar da Administração Pública se aplicam os princípios, garantias e normas que regem o Processo Penal comum, em respeito aos valores de proteção e defesa das liberdades individuais e da dignidade da pessoa humana, que se plasmaram no campo da disciplina" (BRASIL, 2009b)." Por fim, o próprio Sistema Brasileiro de Defesa da Concorrência assim se manifestou em Laboratório Biosintética Ltda v. Laboratório Sandoz S/A (BRASIL, 2008b): “[...] ao processo administrativo em trâmite no Sistema Brasileiro de Defesa da Concorrência se aplica o regime jurídico sancionador, cujos princípios correspondem aos do Direito Penal, inclusive quanto à incidência do art. $5^{\circ}$, inciso XL, da Constituição Federal". Ademais, em GEAP v. AMB (BRASIL, 2007a), a então SDE concluiu que: "embora se reconheça constituírem ramos distintos do Direito, com peculiaridades próprias e inconfundíveis, admitese a existência de um regime jurídico sancionador, de princípios comuns. A esse respeito, cumpre colacionar o magistério doutrinário de Daniel Ferreira: 'Com o devido respeito, e diferentemente do que muitos podem pensar, não há importação de quaisquer dos já consagrados princípios do direito penal (ou do direito processual penal) para o direito administrativo; muito pelo contrário. Tal não quer dizer, evidentemente, inexistirem semelhanças entre as sanções penais e as sanções administrativas, sobretudo no tocante aos princípios de proteção do sujeito sancionado. O que não se pode logicamente negar, pois, é a existência de um mínimo regime Jurídico sancionador, afeto à própria Teoria Geral do Direito e a noção de função pública, através do qual, independentemente da natureza da sanção (penal ou administrativa), reconhecem-se alguns princípios como sendo de cogente aplicação. Tais princípios, representativos de normas comuns à atividade punitiva do Estado - seja na esfera judicial, seja na esfera administrativa -, estão dispostos no artigo $5^{\circ}$ da Constituição da República: [...]”’. 
"demonstrar a sua tese pela culpa do indivíduo" (MORAES, 2009, p. 462). Mais especificamente, caberá a ele provar sua tese incriminadora, seja no que se refere à materialidade do fato, seja à autoria, a fim de atender às disposições constitucionais relacionadas ao juiz natural, à ampla defesa, ao contraditório, à publicidade, ao respeito à intimidade, à integridade física, moral e psicológica, e demais direitos que protegem o indivíduo contra abusos estatais (MORAES, 2009, p. 463).

Destarte, não pode a autoridade antitruste processar e punir os agentes econômicos por uma presunção. Conforme ressaltado por Moraes, "o princípio constitucional da presunção da inocência veda a inversão do ônus probatório [...]" (2009, p. 519), razão pela qual deve a autoridade concorrencial lograr provar objetivamente que a conduta infringe a legislação concorrencial, mais especificamente, causa ou tem o condão de concretamente causar uma lesão ao bem por ela tutelado.

Ademais, cumpre lembrar que não pode existir infração ou crime sem que haja ofensa ao bem jurídico tutelado (nullum crime sine injuria). Tanto no direito penal como no direito administrativo, a ilicitude de uma conduta está condicionada tanto ao seu enquadramento no tipo como também ao seu conteúdo de reprovabilidade ou desvalor (antijuridicidade). ${ }^{121}$

No direito concorrencial, o bem jurídico tutelado é a "concorrência". Somente poderão ser punidas condutas que levem a um risco concreto a esse instituto. Em outras palavras, sem a demonstração de que a conduta do agente, em determinado mercado, realmente poderia por em risco a concorrência, não é possível responsabilizar o agente econômico. ${ }^{122}$

Nessa linha, em Francisco Marcone de Oliveira vs. MP, o Tribunal de Justiça do Rio de Janeiro reconheceu que não se admite no direito sancionador moderno - penal ou administrativo - "o crime de perigo abstrato ou presumido, sendo

\footnotetext{
${ }^{121} \mathrm{O}$ exame da antijuricidade, no entanto, recai justamente sobre a "ofensa ao bem jurídico protegido pela norma que se torna infringida pela realização da ação. Na medida em que não ocorra essa ofensa ao bem jurídico normalmente não se poderá falar de antijuricidade (...)” (CONDE, 1988, p. 85-87).

${ }_{122}$ Nesse sentido, Castaldo (2008, p. 15) afirma que "[...] a existência do nexo causal entre a ação e resultado representa a condição indispensável para considerar o autor como responsável pelo fato cometido". Ao tratar especificamento do crime de cartel, afirmam Ferrari e Gameiro (2004, p. 16) que "no crime de cartel há a necessidade da prova da criação de um perigo efetivo ao bem jurídico concorrência, não havendo presunção absoluta na conduta do acusado". No mesmo sentido, Reale (2006, p. 142) ensina que "a simples combinação sem repercursão na realidade, mera cogitação, não vem a colocar em risco o bem jurídico, pela ausência de resultado consistente na efetiva dominação de mercado e eliminação total ou parcial da concorrência, seja pela criação de situação de perigo com capacidade de dano à concorrência”.
} 
indispensável a prova de que o bem jurídico protegido foi violado ou concretamente ameaçado" (BRASIL, 2011c). No mesmo sentido, em MP vs. Hilton Massuru Kibe, o Tribunal de Justiça de São Paulo consignou que "sem comprovação do perigo concreto à saúde, correta a absolvição" (BRASIL, 2013g).

Portanto, para que um agente seja condenado na esfera antitruste, é necessário que haja evidências robustas de que a conduta imputada alterou ou podia, de fato e realisticamente, alterar a concorrência.

A esse respeito, é contundente a crítica de Bork, sobre a insegurança causada pela condenação "especulativa", sem demonstração de efeitos:

"The practices specified by the Clayton Act were price discrimination with intent to injure a competitor, exclusive dealing, and corporate stock acquisitions. Each of these was to be illegal "where the effect may be to substantially lessen competition or tend to create a monopoly". The incipiency theory was embedded in the superficially innocuous word "may", which has been since said by the Supreme Court to require a "reasonable probability" of a lessening of competition or tendency to monopoly. This verbal formula has proved meaningless. The fallacious economic theory employed by the courts makes the problem of forecasting the relevant economic events so intractable that there is no question of being able to estimate degrees of probability or possibility. The result has been that any imaginary threat of competition, no matter how shadowy and insubstantial, is sufficient to satisfy the "reasonable probability" test" (1978, p. 48).

Nessa linha, é importante que a noção de perigo concreto seja rigorosamente analisada pela autoridade antitruste. A análise da potencialidade não pode ser orientada por subjetivismos. É necessário que o contexto fático permita aferir realisticamente que a conduta tem capacidade de produzir um resultado, isto é, uma lesão ao bem jurídico tutelado. ${ }^{123}$

\footnotetext{
${ }^{123}$ A esse respeito, vale a pena ressaltar que, na União Europeia, há uma tendência de migração de uma análise formalista das condutas anticoncorrenciais para um exame focado nos efeitos da conduta. Nesse sentido, veja: Geradin e Girgenson (GERADIN; GIRGENSON, 2011); Cristian e Stamate (CRISTIAN; STAMATE, 2011). Vale ainda ressaltar que um juiz da Corte Geral da União Europeia propôs adotar, na análise dos cartéis, um foco orientado para os efeitos (ORRICK HERRINGTON \& SUTCLIFFE LLP, 2012).
} 
Com relação a esse tema, é interessante mencionar a doutrina francesa para a qual a condenação per se no direito concorrencial não se coaduna com a liberdade do comércio e o princípio da livre iniciativa, os quais não admitem exceções a não ser a presença de uma ameaça real e séria de perturbação ao processo concorrencial. Trata-se da noção de "limiar de sensibilidade" ou "le seuil de sensibilité", segundo a qual a liberdade contratual e empresarial é a regra. A intervenção da autoridade concorrencial só é legítima em caso de disfunção séria e efetiva (ou ameaça real de disfunção) do mercado (BOUTARD-LABARDE; CANIVET, 1994).

Essas ideias devem ser aproveitadas na interpretação do artigo 36 caput da Lei $n^{\circ}$. 12.529/2011 a fim de evitar a intervenção desnecessária da autoridade concorrencial em casos em que a potencialidade de lesão à concorrência é apenas teórica e não efetiva.

\subsection{Condutas anticoncorrenciais envolvendo o uso de direitos de propriedade intelectual}

\subsubsection{Uma proposta de análise de (i)licitude}

As condutas anticoncorrenciais envolvendo o uso de direitos de propriedade intelectual trazem um elemento complicador de análise na medida em que é necessário ter muita cautela para não se mitigar um direito legitimamente conferido no âmbito da legislação de PI. Ademais, essas condutas, em geral, aparecem no contexto de investigações de práticas exclusionárias que visam ao aumento do custo de rivais (e.g. predação tecnológica), onde é muito difícil separar efeitos competitivos daqueles anticompetitivos, não havendo "testes razoavelmente difundidos e reconhecidos pela comunidade especializada que autorizem inferências no sentido da natureza anticompetitiva de uma determinada inovação" (SCHUARTZ, 2009). Dessa forma, é necessário encontrar um critério jurídico objetivo pelo qual a legislação antitruste preserve os incentivos corretos dos agentes econômicos ao mesmo tempo em que não restrinja direitos regularmente exercidos. 
No campo das práticas exclusionárias, um dos maiores desafios das autoridades concorrenciais é diferenciar o que é estratégia pró-competitiva do que é anticompetitivo (SCHUARTZ, 2009). Ademais, do ponto de vista da teoria econômica, são atribuídos efeitos ambíguos à prática de aumento de custo de rivais: pode resultar num aumento ou diminuição de preço, aumentando ou reduzindo o bem-estar total (HOVENKAMP, 2010).

Dessa maneira, as condutas exclusionárias estão mais propensas a gerar situações de overenforcement (i.e. aplicação de uma sanção superior ao custo social que a conduta produz) e de overdeterrance (i.e. dissuasão de condutas acima do nível socialmente ótimo). Os custos com decisões equivocadas são altos. No caso de overenforcement, envolve a dissuasão ou vedação da conduta inovadora ou diferenciadora e a perda de benefícios para o consumidor. No caso de overdeterrance, sinaliza-se ao mercado a possibilidade de continuação de uma conduta perniciosa. A doutrina especializada sugere que a probabilidade de decisões condenatórias equivocadas em casos de predação tecnológica é grande, "seja porque a quantidade dos casos em que isso de fato se verifica é bastante reduzida, seja em razão da complexidade da análise envolvida no juízo condenatório" (SCHUARTZ, 2009, p. 50).

Nesse contexto, de modo a reduzir os riscos de decisões equivocadas, é necessário o estabelecimento de um critério jurídico objetivo que confira maior grau de previsibilidade jurídica aos agentes econômicos.

No caso de práticas envolvendo o uso de direitos de PI, está-se em jogo não uma análise concorrencial pura e simples, mas sim o balizamento de práticas que envolvem direitos protegidos constitucionalmente e amplamente regulamentados em legislação própria.

No âmbito do controle repressivo de condutas, a autoridade concorrencial está adstrita aos princípios do Processo Administrativo Sancionador, devendo, pois, pautar-se pela estrita legalidade. Nesse sentido, a Administração tem a obrigação de examinar as condutas dos agentes com muita cautela e parcimônia, interpretando-as restritivamente.

Considerando que as condutas envolvendo direitos de PI exijem uma análise harmonizada da política pública de defesa da concorrência, de um lado, e da política pública de proteção à propriedade intelectual, de outro, o conceito de "exercício 
regular de direito" mostra-se como um instrumento jurídico importante na definição da licitude da conduta na medida em que deriva do princípio da legalidade, corolário do Processo Administrativo Sancionador.

Com efeito, o exercício regular de um direito reconhecido é excludente de ilicitude, tanto do ponto de vista civil (art. 188, inc. I, do Código Civil) quanto penal (art. 23, inc. III, do Código Penal). Analogamente, entende-se que se um agente econômico, mais especificamente, um detentor de direito de PI, estiver exercendo seus direitos regularmente, não se pode falar em ilícito administrativo, in casu, ilícito antitruste.

Para aferir o exercício regular de um direito, que equivale à ausência de um abuso, é necessário avaliar se o uso do direito pelo agente econômico está de acordo com sua função social ${ }^{124}$ e dentro dos limites da legislação de PI. Para tanto, é necessário considerar não apenas os dispositivos constitucionais sobre a propriedade intelectual, mas também a sistemática dos direitos e obrigações constantes da legislação ordinária, que, em conjunto, dão ao direito um fim socialmente útil e estabelecem até que ponto eles podem ser exercidos sem que haja um abuso.

A categoria do abuso de direito surgiu a partir de uma construção jurisprudencial que objetivava reprimir atos que, não obstante praticados com estrita observância da lei, estavam em dissonância com seu espírito, sua função. Dessa maneira, a disciplina do abuso de direito visa punir aquela conduta que, "embora lícita, mostra-se desconforme com a finalidade que o ordenamento pretende naquela circunstância fática alcançar e promover" (TEPEDINO; BARBOSA; MORAES, 2011, p. 354). Nesse sentido é o art. 187 do Código Civil, que entende que comete abuso de direito aquele que, "ao exercê-lo, excede manifestamente os limites impostos pelo seu fim econômico ou social, pela boa-fé ou pelos bons costumes". O dispositivo impõe "limites éticos ao exercício das posições jurídicas, seja pelo princípio da boa-fé objetiva, da noção de bons costumes ou da função socioeconômica dos direitos" (TEPEDINO; BARBOSA; MORAES, 2011, p. 346).

\footnotetext{
124 "O dever de empregar os bens de produção segundo sua finalidade, ou mais, especificamente, sua função social obriga seu titular a dar-lhes destino socialmente útil, que considere não somente os interesses individuais do proprietário, mas também os interesses da coletividade" (BRUNA, 2001, p. 140141). Para Possas e Mello, analisar a abusividade do direito significa "esclarecer a finalidade do direito de propriedade intelectual, desde o ponto de vista social, o que não é tarefa simples" (2009, p. 13).
} 
Não é razoável que o agente econômico seja punido por exercer, dentro dos limites constitucional e legalmente estabelecidos, um direito que lhe foi outorgado pelo Estado de forma legítima e válida. ${ }^{125}$ Causaria um alto nível de insegurança jurídica aos administrados se o Estado lhes sinalizasse de forma vacilante o escopo do direito que the foi concedido. Nesse contexto, rechaça-se uma análise antitruste puramente econômica das condutas envolvendo direitos de PI, a qual vise derivar efeitos anticompetitivos do exercício regular de um direito por meio de cálculos imprecisos sobre os efeitos líquidos da conduta.

Em primeiro lugar, como se viu, as condutas exclusionárias, nas quais se inserem a maioria das condutas envolvendo PI, têm efeitos ambíguos, do que não é possível extrair um resultado razoavelmente seguro sobre seu potencial anticoncorrencial, sendo necessário um elemento adicional para a configuração do ilícito - i.e. a abusividade do exercício do direito de PI. Em segundo lugar, direitos de PI, em geral, pressupõem lucros extraordinários para o seu detentor. A autoridade antitruste deve lidar com isso e compatibilizar esse dado com a política de defesa da concorrência.

Diante de uma excludente de antijuricidade - no caso, a presença de um direito exercido em conformidade com sua função social e dentro dos limites da legislação de PI- a analise da regularidade do exercício do direito precede qualquer cálculo ou quantificação dos custos e benefícios sociais da prática. Nesse caso, a constatação de um direito exercido de forma legítima prepondera sobre argumentos que indiquem nexo de causalidade entre a conduta e eventuais perdas ou custos incorridos por concorrentes (SCHUARTZ, 2008).

Entende Schuartz (2009, p. 11) que "a ideia do direito de defesa da concorrência como instrumento de promoção da eficiência (alocativa e produtiva) não pode ir tão longe a ponto de se fazer da obtenção de ganhos de eficiência uma obrigação jurídica”. Dentro dessa perspectiva, o fato de o art. 36, $\S 1^{\circ}$, da Lei $n^{\circ}$. 12.529/2011 prever que "a conquista de mercado resultante de processo natural fundado na maior eficiência de agente econômico em relação a seus competidores não caracteriza o ilícito

\footnotetext{
${ }^{125}$ Segundo Tepedino, Barboza e Moraes (2011, p. 349), “(...) o exercício regular de um direito, ainda que gere dano a alguém, não deflagra o dever de reparar. (...) O dano causado sem violação ao direito é um dano justo e, como tal, não serve de elemento ao ato ilícito e não pode gerar o dever de indenizar. À noção de exercício regular do direito opõe-se o exercício abusivo ou abuso de direito".
} 
(...)" não significa que a legislação concorrencial não abarque outras hipóteses de antijuridicidade.

Apenas no caso de ser constatado um exercício abusivo de direito de PI, é que se deve proceder à verificação de um nexo de causalidade entre o uso abusivo do direito de PI e a disfunção (real ou potencial) do mercado.

A análise, portanto, é dual. Analisa-se, primeiro, a regularidade do exercício do direito. Em segundo, caso constatado o abuso, verifica-se o nexo de causalidade entre o uso abusivo do direito de PI e a disfunção do mercado por meio dos instrumentos tradicionais da análise antitruste, isto é, análise de (i) poder de mercado do agente, (ii) efeitos anticoncorrenciais da conduta, (iii) eficiências relacionadas a ela (se existentes) e, finalmente, (iv) os resultados do balanceamento entre os efeitos anticoncorrenciais e as eficiências da prática, dentro da perspectiva da regra da razão (POSSAS; MELLO, 2009).

Dada a natureza ambígua dos efeitos das práticas exclusionárias, Scheffman e Higgins defendem que essas práticas só devem ser investigadas se há um "credible concern that the result is anticompetitive" (2003, p. 382). ${ }^{126}$ Neste cenário, é muito importante que a análise da potencialidade de efeitos da conduta, nos termos do art. 36 da Lei $\mathrm{n}^{\circ}$. 12.529/2012, seja feita de modo rigoroso. A autoridade concorrencial não deve fazer presunções infundadas ou especulações sobre efeitos potenciais da conduta. As evidências de prática anticompetitiva devem ser robustas.

Nesse contexto, a visão expansionista da legislação antitruste, que busca sua prevalência sobre as normas de direito de propriedade intelectual, é inapropriada.

\footnotetext{
${ }^{126}$ Os autores esclarecem que: "[B]oth the original RRC article, and later articles, make clear that as a matter of economic theory, the effects of cost-raising strategies are ambiguous. The fact that a dominant firm engages in cost-raising strategies does not prove, by itself, as a matter of economic theory, that such strategies are anticompetitive. It is important to understand this theoretical ambiguity, particularly in light of the many papers, written since the RRC paper, that focus on the potential for vertical mergers to be anticompetitive (...). The analyses in the RRC papers largely focus on a situation with a dominant firm that is assumed to have significant market power, independent of any cost-raising strategies. Although it appears pretty simple, the model is actually quite complex in generating general results, as are all general models that involve market power short of monopoly. Thus, as is pointed out clearly in Salop and Scheffman's 1987 paper, as a matter of theory, cost-raising strategies by a dominant firm may raise or lower price, raise or lower total welfare, and even raise or lower the profits of the "victims." The ambiguity in the effects of cost-raising strategies arises from a number of sources. The most straightforward reason is that, in the models, the dominant firm prices according to the elasticity of demand that it faces. A cost-raising strategy shifts out the demand faced by the dominant firm, but it is possible that it also makes the demand more elastic - sufficiently more elastic that the profit maximizing price falls. Again, RRC theory lays out, in principle, testable conditions under which, in a specific situation, cost-raising strategies are likely, from an economic perspective, to be anticompetitive" (SCHEFFMAN; HIGGINS, 2003, p. 378).
} 
Tanto a legislação de concorrência quanto a legislação de PI estão a serviço de uma política econômica mais ampla. Mitigar direitos já estabelecidos (i.e. os direitos de PI) como resultado de uma interpretação puramente econômica traria enorme insegurança jurídica.

Os direitos de PI, assim como outros direitos de propriedade, têm uma função socioeconômica e uma razão de ser. Dessa forma, não podem ser mitigados a menos que haja um desvio. Do contrário, sua proteção - que tem por objetivo incentivar a inovação e o processo competitivo por meio da criação de um direito de exclusividade que possibilitará ao detentor apropriar-se exclusivamente de seu valor - seria esvaziada e, ainda, a segurança jurídica que deve nortear o ordenamento jurídico restaria seriamente ameaçada.

Esse debate tem sido frequente nas autoridades concorrenciais de todo o mundo. Não há ainda um tratamento uniforme nos casos antitruste envolvendo direitos de PI. Tampouco a análise dual aqui proposta para a caracterização do ilícito antitruste está consolidada, conforme se verá no tópico a seguir. Em certos casos, a autoridade concorrencial sequer analisa se houve um abuso de PI pelo seu titular, examinando apenas os efeitos da conduta sobre o mercado.

Como se sabe, todavia, se analisados sob uma perspectiva estática e a curto prazo, os direitos de PI podem parecer anticompetitivos. No entanto, o cenário muda se analisados sob uma perspectiva dinâmica e de longo prazo. É necessário ter em mente o direito de PI no contexto de uma política pública, que, associada a outras, tem um objetivo maior.

Por essa razão, é tão importante verificar, em um primeiro momento, se esses direitos estão sendo exercidos de forma regular. ${ }^{127}$ Do contrário, é possível que se infira, erroneamente, um efeito anticoncorrencial de um direito legitimamente exercido, o que ensejaria a injusta punição do seu titular. Não é novidade que a análise dos efeitos líquidos da conduta é um cálculo impreciso. Desse modo, um alto grau de confiança nesta etapa da análise em condutas de predação tecnológica podem levar a muitos erros Tipo II (condenação de práticas não competitivas).

\footnotetext{
${ }^{127}$ Vale ressaltar que o exercício regular de um direito reconhecido é excludente de ilicitude, nos termos do art. 188, inc. I, do Código Civil.
} 
A aplicação de princípios antitruste aos direitos de propriedade intelectual, nesse sentido, deve ter especial consideração ao direito de exclusiva legitimamente garantido pela Constituição Federal. Conforme explicitado por Marquardt e Leddy, um direito de exclusiva não pode ser mitigado por conferir uma vantagem competitiva decisiva a um agente econômico. Sua razão de ser relacionada à proteção da inovação exige que ele seja protegido independentemente de resultar em uma vantagem concorrencial ou conferir poder de mercado ao seu titular (MARQUARDT; LEDDY, 2003, p. 848).

Esta ideia coaduna-se com o conceito de "competition on the merits", consagrado há tempos no direito brasileiro pela noção de que a vantagem competitiva adquirida legitimamente (ou resultante de um processo natural) não pode ser punida (FORGIONI, 1997, p. 48-50). Por essa razão, considera-se que o exercício do direito de PI exercido em conformidade com a sua função social é uma excludente de ilicitude no âmbito do controle repressivo de condutas.

4.3.2. Análise de ilicitude conduzida pelas autoridades antitrustes em casos envolvendo direitos de PI.

(i) Europa

Nos principais casos julgados pela Comissão Europeia ou pela Corte Europeia de Justiça (ECJ) envolvendo uso abusivo de direitos de PI por empresas com posição dominante, em geral, partiu-se do exame dos efeitos da conduta, sem se analisar se os direitos de PI estavam sendo exercidos de forma regular.

Para estas autoridades, prevalece a "doutrina das circunstâncias excepcionais" ("exceptional circumstances doctrine") segundo a qual o exercício legítimo de um direito de PI pode, em circunstâncias excepcionais, ser punido do ponto de vista concorrencial (RIBEIRO; ROLIM, 2011).

Em Radio Telefis Eireann (RTE) and Independent Television Publications Ltd (ITP) v. Commission (EUROPA, 1995) e IMS Health GmbH \& Co. OHG v. NDC Health GmbH \& Co. KG. (EUROPA, 2004b), a ECJ, corroborando a 
análise da Comissão Europeia, realizou um exame da conduta em si sem qualquer ponderação com relação à função dos direitos de propriedade analisados e à regularidade ou irregularidade do seu exercício.

Em IMS Health, foram analisadas as condições desenvolvidas em RTE $e$ $I T P$, isto é, as circunstâncias especiais ou excepcionais que deveriam estar presentes para que a conduta fosse considerada anticoncorrencial.

Particularmente, foi verificado se a recusa de um titular de direito autoral a licenciar o seu direito a outro agente (i) impedia o desenvolvimento de um novo produto para o qual haveria demanda potencial; (ii) era objetivamente injustificada e (iii) excluía a concorrência num mercado secundário. Nenhum desses critérios, todavia, abre o devido espaço para a análise da regularidade do exercício do direito de PI.

Em primeiro lugar, o fato de a recusa de uma patente impedir o desenvolvimento de um novo produto para o qual haveria demanda potencial não poderia, a princípio, resultar numa intervenção da autoridade antitruste. A criação de barreiras ao desenvolvimento de um novo produto somente pode ser considerada abusiva quando resta caracterizada uma situação de dependência entre o titular da patente e os potenciais usuários e/ou a patente represente uma espécie de "essential facility" para os concorrentes.

Em segundo lugar, a exigência de justificativa objetiva para o licenciamento pode até representar um parâmetro relevante para a autoridade antitruste auferir a potencialidade lesiva da prática. No entanto, conforme colocado no item acima, é importante, no caso de condutas que envolvam direitos de PI, que se analise preliminarmente a regularidade do exercício desse direito para averiguar, desde logo, se há uma excludente de ilicitude. Do contrário, as justificativas da conduta podem perderse na análise antitruste, sendo ofuscadas, por exemplo, pela análise dos efeitos líquidos da conduta cujo cálculo é a priori impreciso.

No caso Microsoft (EUROPA, 2004a), a empresa justificou sua recusa em licenciar certos direitos de PI com base na proteção legal a eles conferida, que tem por objetivo proteger os altos investimentos dos agentes econômicos em pesquisa e desenvolvimento de tecnologias e, assim, estimular a inovação.

A Comissão Europeia (EUROPA, 2004a), no entanto, considerou que a explicação da Microsoft "cannot as such constitute a self evident. objective justification 
for Microsoft's refusal to supply". De acordo com a autoridade, a função central dos direitos de PI seria proteger os direitos morais do trabalho do seu titular e assegurar uma recompensa pelo seu esforço criativo. No entanto, também seria um objetivo da legislação de PI estimular a criatividade para o bem geral do público ( "general public good"). Nesse sentido, concluiu que a recusa de uma empresa em conceder uma licença, pode, em circunstâncias excepcionais, ser contrária ao bem geral do público na medida em que constitua um abuso de posição dominante com efeitos adversos sobre a inovação e sobre os consumidores.

A autoridade europeia não analisou se a Microsoft estava exercendo seu direito de PI de forma abusiva e fez referência a um princípio genérico ("general public good") que dá margem a uma interpretação muito ampla sobre a possibilidade de intervenção antitruste, o que enseja resultados imprevisíveis e gera incerteza jurídica (FORRESTER, 2004, p. 941).

Em terceiro lugar, a recusa de licenciar que tem por efeito a exclusão da concorrência num mercado secundário somente poderia ser considerada ilícita do ponto de vista social se, de fato, o titular do direito o estivesse exercendo fora dos limites legais (e.g. extensão indevida do escopo da patente).

Nesse ponto, importante as considerações de Ribeiro e Rolim (2011, p. 6) que entendem que a imposição de restrição a direitos de PI com base em efeitos em mercados correlacionados limita o exercício regular de um direito. Para as autoras, "as consequências de tais posicionamentos em termos de equilíbrio entre segurança jurídica, proteção ao investimento em pesquisa e manutenção de adequado e eficiente nível de concorrência no mercado [...] ainda restam pouco claras".

Portanto, conforme se verifica, não há na Europa uma análise preliminar sobre a regularidade (ou abusividade) do exercício do direito de PI, tendo em vista a sua função social e os objetivos específicos da legislação correspondente. A autoridade concentra-se nos efeitos da conduta sobre o mercado, independentemente desta ser resultado do exercício legítimo de direito de PI. 
A análise dual proposta neste trabalho tem origens na jurisprudência norte-americana. Uma das primeiras decisões a aplica-lá remonta a década de 40. Tratase do caso Ethyl Gasoline Corp. v. United States (EUA, 1940), que envolvia a aplicação, pela Ethyl, de algumas restrições de revenda de um fluido sobre o qual detinha direito de patente, incluindo fixação de preços de revenda e divisão territorial do mercado. A Suprema Corte norte-americana utilizou-se de dois critérios para avaliar a conduta da empresa. Em primeiro lugar, avaliou se ela estava dentro do escopo da autorização concedida pelo direito patentário e, em seguida, analisou os seus efeitos sobre a concorrência (CARVALHO, 1994). Posteriormente, em Mercoid Corp v. MidContinent Inv. Co. (EUA, 1944), adotou a mesma metodologia.

Na visão de Carvalho, o critério utilizado pelo tribunal nesses dois casos é "primeiro, descobrir se o titular usou os seus direitos inerentes ou se ele ultrapassou a fronteira legal desses direitos. Se a resposta é que ele usou efetivamente os seus direitos inerentes, parte-se do princípio de que não há qualquer ilegalidade a punir. Mas se os direitos inerentes tiverem sido excedidos, e se a conduta do titular, por conseguinte, não estiver mais protegida pela patente, os efeitos anticompetitivos dessa conduta devem ser verificados" (1994, p. 64).

Mais tarde, a Corte de Apelação do Segundo Circuito, em SCM Corp. vs. Xerox Corp. (EUA, 1981), e a Corte de Apelação do Circuito Federal, em Mallinckrodt, Inc. v. Medipart, Inc. (EUA, 1992) aplicaram o mesmo racional.

É importante ressaltar, todavia, que esse tipo de abordagem no direito norte-americano não é consistente. A doutrina do "patent misuse" desenvolvida pelos tribunais estadunidenses analisa o abuso de patente à luz de princípios antitruste, da própria legislação patentária ou, ainda, de outras políticas públicas (HOVENKAMP, 2011).

Depois da edição, em 1988, do Patent Misuse Reform Act ${ }^{128}$, por meio do qual se inseriu um critério de razoabilidade econômica para que se pudesse levantar o

12835 U.S.C.A. $§ 271(\mathrm{~d})$ : "No patent owner otherwise entitled to relief for infringement or contributory infringement of a patent shall be denied relief or deemed guilty of misuse or illegal extension of the patent right by reason of his having done one or more of the following: (1) derived revenue from acts which if performed by another without his consent would constitute contributory infringement of the 
argumento do "misuse", muito se discutiu sobre se este instituto deveria ser regido unicamente por princípios antitruste. No entanto, as decisões continuam a oscilar a esse respeito, ora aplicando a metodologia de análise concorrencial, ora utilizando-se de outros princípios (HOVENKAMP, 2011).

De qualquer maneira, conforme ressaltado por Marquardt e Leddy, "US courts have consistently distinguished legitimate assertions of the right to exclude in inherent intellectual property rights and illegitimate attempts to leverage or otherwise abuse those rights, often speaking in terms of assertions of intellectual property rights that are within or without the scope of the right itself' (2003, p. 864-865), o que demonstra uma preocupação em separar o exercício legítimo de direitos de PI daquele uso abusivo, que pode ter consequências na esfera do direito da concorrência.

(iii) Brasil

O CADE não tem uma metodologia bem definida na análise de condutas envolvendo direitos de PI.

No caso das Autopeças, o então conselheiro Carlos Emmanuel Ragazzo buscou destacar em seu voto a importância de uma análise dos "fins econômicos e sociais dos direitos de propriedade industrial em questão, essencialmente como instrumentos de incentivo à diferenciação e inovações no mercado" (BRASIL, 2010, p. 20). No entanto, o método indicado por ele para aferição do caráter anticoncorrencial da conduta investigada baseou-se preponderantemente numa análise dos efeitos da conduta sobre o bem-estar do consumidor sem que houvesse qualquer análise prévia sobre a regularidade do exercício do direito de PI subjacente. Nesse sentido, entendeu Ragazzo (BRASIL, 2010) que:

“(...) se a análise econômico-concorrencial constatar que a imposição dos registros de desenho industrial das montadoras diante dos FIAPs

patent; (2) licensed or authorized another to perform acts which if performed without his consent would constitute contributory infringement of the patent; (3) sought to enforce his patent rights against infringement or contributory infringement; (4) refused to license or use any rights to the patent; or (5) conditioned the license of any rights to the patent or the sale of the patented product on the acquisition of a license to rights in another patent or purchase of a separate product, unless, in view of the circumstances, the patent owner has market power in the relevant market for the patent or patented product on which the license or sale is conditioned". 
estiver gerando mais malefícios do que benefícios ao bem-estar econômico e social, estará caracterizado o exercício abusivo do direito, e portanto sua ilicitude. Tal se dará porque ficará demonstrado que a aplicação dos direitos de propriedade industrial pelas representadas, ao menos desse modo (contra FIAPs), não estará atendendo às necessidades sociais de inovação e desenvolvimento, mas sim, meramente funcionando como meio de alavancar o poder econômico das montadoras, em prejuízo dos consumidores e do bemestar da economia".

Ou seja, busca o Conselheiro derivar a abusividade de um direito de PI não a partir de uma análise dos limites do seu exercício à luz de sua função social, mas sim de um cálculo imperfeito dos custos e benefícios sociais da conduta. Nesse cenário, independentemente de o exercício do direito sobre desenho industrial ser exercido regularmente pelas montadoras, o então Conselheiro apontou que, se, de uma análise de custo-benefício da conduta, for obtido um resultado negativo para o bem estar do consumidor, então, ela será considerada anticoncorrencial.

Esse raciocínio ignora o fato de que a busca do lucro supra-competitivo é justamente aquilo que impulsiona os agentes econômicos a inovarem e, dessa maneira, parece inadequado tornar o calculo dos efeitos líquidos da conduta o elemento central para a caracterização da ilicitude (SCHUARTZ, 2009). Ademais, como visto, a proteção ao direito industrial está no mesmo patamar que a defesa da concorrência, pois ambas as políticas foram relativizadas na Constituição Federal. Nesse sentido, uma não pode sobrepor-se à outra.

Conforme já mencionado, a verificação da abusividade do exercício do direito de PI, tendo em vista sua função social, deve ser feita antes e independentemente da análise econômico-concorrencial. Uma análise conjugada poderia resultar em distorções como a punição do poder de mercado legitimamente obtido. Por essa razão, é importante que se analise, em um primeiro momento, se o direito de PI está sendo exercido regularmente dentro dos próprios objetivos da legislação de PI e não no contexto de um equacionamento dos efeitos líquidos da conduta sobre o bem estar do consumidor.

Nesse esteio, importante são as conclusões de Hovenkamp, que ao discorrer de condutas anticoncorrenciais envolvendo direitos de PI, explica que the all 
important question (...) is whether the patentee has (1) commited an exclusionary act that is (2) not authorized by patent law" (2008, p. 5).

Nessa linha, pode-se dizer que só caberia uma analise concorrencial do caráter exclusionário de dada prática, se, após analisar os objetivos da legislação de propriedade intelectual, concluir-se que a forma como o direito de PI foi exercido não se coaduna com a sua função socioeconômica.

Conforme ensina Comparato, “[...] a consideração exclusiva dos aspectos concorrenciais, no regime das patentes, acarreta a negação prática de sua função social de estímulo às invenções de interesse à coletividade" (1995, p. 44).

No caso ABTA v. ECAD e outros (BRASIL, 2013a), o CADE identificou que o Escritório Central de Arrecadação e Distribuição (ECAD), em conjunto com associações representantes de músicos e compositores, teriam extrapolado o escopo da Lei no . 9.610/98 (Lei de Direitos Autorais) e fixado em conjunto os valores referentes aos direitos de execução pública de obras musicais, lítero-musicais e fonogramas.

Para tanto, o Conselheiro Elvino Mendonça analisou as funções e objetivos dos detentores de direitos autorais, usuários, ECAD e associações à luz da Lei de Direitos Autorais, concluindo que esta confere ao ECAD o controle da atividade de arrecadação e de distribuição dos direitos autorais, mas não o tabelamento de seus preços.

Nesse caso, portanto, é possível perceber que houve uma preocupação do Conselheiro de analisar preliminarmente o escopo da legislação de direito autoral para verificar se a conduta do Representado seria respaldada nos termos desta lei para, então, proceder a uma análise de cunho concorrencial, seguindo a linha de uma análise dual.

Nos casos envolvendo direitos de PI derivadas de fraudes ou abusos nos procedimentos de registro, por sua vez, o CADE sempre analisa a existência de fraude e abuso sob o ponto de vista da legislação de PI antes de extrair qualquer conclusão de natureza concorrencial.

No caso Nilton Filho vs. Alcoa Alumínio S.A. (BRASIL, 2010c), a representada foi acusada de restringir a concorrência na oferta de perfis de alumínio por meio de pedidos fraudulentos de registros de desenho industrial e patentes de modelo de utilidade junto ao INPI, seguidos de ações judiciais ajuizadas contra os supostos 
violadores desses direitos. No entanto, nos termos da decisão proferida pelo CADE, “os pedidos de registro de desenho industrial tiveram seu mérito submetido à instância administrativa competente, não caracterizando conduta oportunista em face de eventual brecha anticompetitiva nos procedimentos de concessão". Diante dessa conclusão, o CADE constatou que o mérito do processo antitruste também restaria prejudicado.

No caso Shop Tour (BRASIL, 2010d), no qual o CADE investigou a prática de produtoras do programa "Shop Tour", as quais ajuizaram uma série de ações judiciais com o propósito de tirar do ar programas concorrentes sob a alegação de que teriam o registro de Direito Autoral sobre o formato do programa de vendas pela televisão junto ao arquivo da Biblioteca Nacional, o então Conselheiro Vinícius Marques de Carvalho fez uma análise detalhada sobre cada uma das ações e do mérito de cada um delas nas $1^{\text {a }}$ e $2^{\mathrm{a}}$ instâncias a fim de avaliar, de um lado, se elas teriam fundamento e, de outro, se as empresas teriam agido de má-fé ao ajuizá-las.

No caso, o Conselheiro afirmou que "para quem tem mais traquejo na área de Direito Autoral, sabe que apenas haveria infração ao direito das requerentes se houvesse reprodução ipsis litteris do programa arquivado na Biblioteca Nacional" (BRASIL, 2010d, p. 8). Com isso, concluiu que "todas as ações tiveram [...] pretensões que a parte sabia de antemão serem precárias, dadas as diversas manifestações do judiciário no sentido oposto". Constatada a violação à legislação de direito autoral, o Conselheiro prosseguiu com a análise dos efeitos anticoncorrenciais da conduta.

Entende-se que não há razões para se realizar análises opostas nas condutas envolvendo o abuso de procedimentos de registro de direito de propriedade intelectual e naquelas envolvendo abuso do próprio direito. Nos dois casos, há necessidade de se avaliar se há um exercício regular de direito de PI para, depois, se aferir se há violação das normas antitruste. 


\subsection{Abuso do direito de marca sob a perspectiva do direito concorrencial}

\subsection{1. $\quad$ Considerações iniciais}

No âmbito da autoridade concorrencial brasileira, até algum tempo atrás, nas décadas de 80 e 90, havia o entendimento de que violações a direitos de marca, incluindo atos de concorrência desleal, eram alheios à competência do CADE e refugiam inteiramente aos objetivos da Lei Antitruste. ${ }^{129}$ Mesmo nas poucas decisões julgadas recentemente pelo CADE sobre o tema de abuso de marca e concorrência desleal, muito embora já haja clareza no sentido de que tais atos podem implicar violações à lei antitruste, ainda está pouco claro qual o critério mais adequado para analisar esses casos.

Além disso, há certa nebulosidade quanto à competência da autoridade antitruste para analisar questões específicas, ${ }^{130}$ uma vez que se trata de uma matéria que é comum a diversos ramos do Direito e pode ser analisada por instâncias decisórias distintas. Mais especificamente, questões marcárias podem ter implicações não só no Direito de Propriedade Intelectual, mas também, no Direito do Consumidor, no Direito Antitruste e no Direito Penal, e ser analisadas no âmbito cível (jurisdição cível), penal (jurisdição penal) e administrativo (INPI, CADE, PROCON). Neste contexto, podem surgir dúvidas quanto aos limites da atuação da autoridade concorrencial.

Diante dessas questões, busca-se nas seções abaixo (a) verificar de que forma deveria ser realizada a apreciação de casos envolvendo abuso de marcas e, ainda, (b) analisar o escopo de atuação da autoridade antitruste na análise dessas condutas.

\subsection{2. $\quad$ Abuso de posição dominante e marca}

De maneira geral, as condutas envolvendo o uso indevido da marca que tenham efeitos no âmbito do Direito Antitruste estão situadas, assim como o abuso de

\footnotetext{
${ }^{129}$ Nesse sentido, Bombril v. Lamisa (BRASIL, 1983); Santa Branca v. Terra Branca (BRASIL, 1987a); Vinhos e Bebidas Caldas / Bebidas Cinzano (BRASIL, 1987b).

${ }^{130}$ Vide, a título ilustrativo, o parecer da SG no caso Vigor v. Kellog e Danone (BRASIL, 2013e).
} 
outros direitos de PI, na categoria de condutas exclusionárias. $\mathrm{O}$ agente com posição dominante pode valer-se de prerrogativas atinentes à legislação marcária com o propósito de excluir concorrentes por meio do aumento do custo de rivais.

Todavia, o fato de uma empresa engajar-se em uma prática de aumento de custo de rivais não prova, por si só, em termos de teoria econômica, que a prática é anticompetitiva. Do ponto de vista jurídico, em linha com a análise dual proposta no item 4.3.1, apenas haverá um ilícito antitruste se houver (i) um exercício irregular do direito marcário; (ii) evidências robustas de que este exercício irregular resultou em efeitos reais ou potenciais sobre a concorrência. Nesse ponto, oportuno é o posicionamento da SG, em Kaiser vs. Ambev, no sentido de que "discussões marcárias de boa-fé, em que não se consiga demonstrar a intenção/possibilidade de restrição à concorrência, ou batalhas judiciais atinentes à concorrência desleal entre agentes desprovidos de poder de mercado tendem a não gerar impactos mercadológicos, sendo, portanto, querelas eminentemente privadas" (BRASIL, 2013b, p. 17).

Uma vez que a análise da regularidade dos direitos leva em consideração a função social do instituto bem como os limites impostos pela legislação pertinente, retomam-se aqui as conclusões do Capítulo 2. Conforme visto, a marca é uma "propriedade constitucional que se realiza na concorrência e pela concorrência" (BARBOSA, 2008, p. 241). Nesse sentido, sua função social está intimamente ligada às regras que lhe permitem proteger os investimentos na reputação empresarial de seu titular, coibir comportamentos oportunistas de terceiros e proteger consumidores contra confusão. A distintividade da marca perante terceiros, garantida pelas regras da especialidade e das marcas notórias, e a coibição de comportamentos desleais, disciplinada pelas regras de concorrência desleal mostram-se como parâmetros importantes para analisar a regularidade da conduta do agente econômico.

As seções abaixo analisam algumas práticas que, em tese, poderiam ser suscetíveis de análise pela autoridade concorrencial. São elas: atos de concorrência desleal, abusos e fraudes em procedimentos de registro de marca, práticas discriminatórias envolvendo marcas de certificação, questões ligadas ao licenciamento de marcas e predação por meio de diferenciação por marcas. 
a. Inegável intersecção com o Direito Antitruste

As normas que disciplinam os atos de concorrência desleal no âmbito da LPI visam tutelar o concorrente. Por outro lado, o direito antitruste busca proteger a concorrência. No entanto, os mesmos fatos podem gerar efeitos em ambas as esferas na medida em que prejudique o concorrente e, simultaneamente, a concorrência (FORGIONI, 2014).

A preocupação com os atos de concorrência desleal que tenham efeitos sobre a concorrência - e não concorrentes, estava presente desde a primeira lei concorrencial brasileira. A Lei $\mathrm{n}^{\circ}$. 4.137/62 trazia dentre as categorias de ilícito a concorrência desleal (art. $2^{\circ}$, inc. V), buscando preservar, além da concorrência, a lealdade da conduta dos agentes do mercado (SALOMÃO FILHO, 2007). A Lei ${ }^{\circ}$. 8.884/94, contudo, não fez qualquer referência à concorrência desleal como forma de infração à ordem econômica, o que fez "com que algumas práticas anticompetitivas listadas no art. 21 da nova lei pareçam estar desalinhadas, vez que alguma delas foram literalmente copiadas da Lei $\mathrm{n}^{\circ} .4 .137 / 62(\ldots)$, na qual tais condutas eram identificadas como práticas de concorrência desleal” (TIMM, 2009, p. 99). A Lei no. 12.529/2011 segue a mesma linha da Lei $n^{\circ}$. 8.884/94.

Conforme explica Salomão Filho (2007, p. 55), "garantir a concorrência significa, a um só tempo, garantir coisas diversas”. De fato, para a manutenção da concorrência, é necessário, em primeiro lugar, um comportamento leal dos agentes consistente em uma atuação que se baseie numa concorrência de méritos (e não no desvio de clientela alheia), a qual assegure o fluxo de informações para o consumidor (i.e. não resulte em atos enganosos e confusórios). Em segundo lugar, é imprescindível a garantia direta das relações econômicas.

Olavo identifica essa garantia de um comportamento leal com a liberdade de concorrência sob um aspecto subjetivo, isto é, a liberdade de cada agente econômico poder entrar em um dado mercado e nele desenvolver-se. A repressão à concorrência desleal, nesse sentido, resulta "na imposição de deveres no sentido de os vários empresários que actuam no mercado procederem honestamente" (2005, p. 248). Para 
autor, a liberdade de concorrência sob este aspecto subjetivo "é condição necessária, mas não suficiente, da concorrência em sentido objetivo" (2005, p. 247).

A existência de um comportamento leal, portanto, é pressuposto da existência de efetiva concorrência. Por essa razão, os atos de concorrência desleal têm o condão de afetá-la. Naturalmente, para que um ato de concorrência desleal possa afetar a concorrência em seu sentido objetivo, isto é, a competição considerada em si mesmo, é necessário que, em primeiro lugar, seja praticada por um agente com posição dominante e, em segundo lugar, que as condições do mercado em termos de barreiras à entrada, condições de rivalidade, etc., permitam que a conduta do agente tenha o potencial de causar disfunções ao mercado. Tudo isso depende de um exame robusto de provas.

Nesse sentido, o CADE, em Oxigases v. White Martins (BRASIL, 2007c), ao analisar caso envolvendo suposto ato de concorrência desleal, entendeu que:

“(...) a intervenção do Conselho apenas possa fazer-se presente (i) se o dano puder transbordar a lide privada par ganhar contornos difusos e (ii) sob a condição sine qua non de que o ilícito possa ser tipificado como infração à ordem econômica. Observo, primeiramente, que a primeira das condições se encontra perfeitamente preenchida, ante a constatação do poder de mercado da representada. Por outro lado, o que faz com que uma infração de concorrência desleal se transforme em um ilícito antitruste é (i) a existência de poder de mercado e (ii) a possibilidade de que tal prática crie dificuldades à constituição, ao funcionamento ou ao desenvolvimento de empresa concorrente ou de fornecedor, adquirente ou financiador de bens ou serviços e, portanto, tenha a possibilidade de gerar efeitos nocivos aos consumidores."

O Conselho entendeu, no caso, que embora o ato de concorrência desleal estivesse bem caracterizado, havia poucos documentos hábeis a instruir o caso e demonstrar a potencialidade de efeitos anticompetitivos da conduta. De qualquer modo, não restam dúvidas de que os atos de concorrência desleal podem, sob circunstâncias específicas, transbordar a esfera privada e atingir o bom fluxo das relações econômicas, sendo a autoridade concorrencial competente para dirimir essas questões. 
b. Aparentes conflitos de competência

Em casos de concorrência desleal que envolvam questões marcárias como, por exemplo, a reprodução total ou parcial de marca ou trade dress de concorrentes, é necessário que se tenha em mente que a análise da conduta no âmbito do Judiciário, do INPI e do CADE serão independentes, conforme discutido no Capítulo 2. Nesse sentido, uma instância não está adstrita ao pronunciamento de outra, a menos que seja uma decisão do Poder Judiciário revendo um ato administrativo.

O INPI analisará a existência de "reprodução ou imitação, no todo ou em parte, ainda que com acréscimo, de marca alheia registrada, para distinguir ou certificar produto ou serviço idêntico, semelhante ou afim, suscetível de causar confusão ou associação com marca alheia" no contexto específico de pedidos de registros de marca, nos termos do art. 124, XIX, da LPI. O Judiciário analisará a reprodução, sem autorização, de marca alheia no contexto de uma ação penal, sob o fundamento do art. 189, inc. I, da LPI, ou, ainda, no contexto de uma ação cível, quando esta tenha por objeto um pedido de reparação por violação de direitos de PI e atos de concorrência desleal, nos termos do art. 209 da LPI. O CADE, por sua vez, verificará se o ato tem o condão de causar dano à concorrência.

Trata-se de mesmos fatos que poderão ser analisados por todas as instâncias, que deverão emitir pronunciamentos dentro de suas esferas de competência. Nesse ponto, interessante é o pronunciamento do TRF-3, em Orlando Cezar e outros v. União Federal (BRASIL, 2000b) no sentido de que a autonomia de um ramo de Direito é capaz de alterar institutos e figuras de outros ramos para atender à sua própria finalidade:

“4. A autonomia do Direito Tributário, para atender aos seus peculiares fins, permite a alteração das características de institutos e figuras de outros ramos do Direito, motivo pelo qual não é "ilógico" ou "anti-jurídico" que, eventualmente, ocorram decisões conflitantes na esfera penal e na esfera tributária."

Igualmente, em União Federal v. Dacio Puzzi e outros (BRASIL, 2012d), o mesmo tribunal entendeu que "a autonomia do Direito Tributário neutraliza os efeitos 
tradicionais dos institutos, conceitos e formas de direito privado e lhes confere uma fisionomia própria, específica".

Em sentido análogo, em sendo o Direito Concorrencial um ramo autônomo, sua análise, pelo CADE, implicará, por vezes, interpretar as figuras típicas de outros ramos, como o de Propriedade Intelectual, tendo em vista o seu objetivo de apreciar aquelas condutas que tenham por objetivo ou efeito afetar adversamente a concorrência. ${ }^{131}$

Dessa forma, um ato de concorrência desleal poderá não ser analisado da mesma maneira pelo CADE, pelo Judiciário e pelo INPI. Resultados aparentemente conflitantes entre as decisões decorreriam da própria autonomia dos ramos do Direito e das instâncias decisórias, sem que isto implique a ausência de lógica do sistema jurídico.

Consideradas essas premissas, critica-se aqui a visão da SG em Vigor v. Kellog e Danone (BRASIL, 2013e). Nesse caso, dentre outras acusações, a Vigor alegava que a Danone teria abusado de seus direitos de petição e de propriedade intelectual ao ajuizar ação em face da Vigor, sob a alegação de que esta empresa teria violado seus direitos de PI por meio de contrafação e praticado concorrência desleal no segmento de iogurtes funcionais. De acordo com a Vigor, não teria havido violação de trade-dress dos produtos da Danone e esta teria ajuizado ação com pedido genérico que poderia culminar na suspensão de todos os direitos de produtos da Vigor e no impedimento desta empresa de usar seus direitos de PI, o que o condão de afetar a concorrência no mercado de iogurtes.

A SG, seguindo a tradição jurisprudencial em matéria de sham litigation, buscou analisar se haveria "indícios de que a ação tenha sido proposta com o objetivo exclusivo de prejudicar a concorrência, utilizando-se de uma simulação" (BRASIL, 2013e, p. 22). Naturalmente, a análise da existência de uma simulação é um elemento importante para aferir se o direito está sendo exercido regularmente. No entanto, a autoridade não está limitada à análise deste elemento ou de outros elementos típicos de sham litigation como má-fé, existência de "clara carência das condições de ação",

\footnotetext{
${ }^{131}$ Se o CADE tivesse de aguardar o pronunciamento do Poder Judiciário ou do INPI sobre determinada questão, a repressão de condutas anticoncorrenciais envolvendo direitos de PI seria impraticável ou, no mínimo, ineficiente, uma vez que o provimento do CADE muito provavelmente demoraria muito tempo para ser dado.
} 
"expedientes objetivamente sem fundamento", “ação manifestadamente improcedente". ${ }^{132}$. Como, no caso, havia não só uma acusação de sham litigation, mas também de violação de direito de propriedade intelectual, o CADE poderia analisar o mérito dessa violação com o objetivo de avaliar se o direito estava sendo exercido regularmente. Em caso negativo, estaria aberto espaço para a análise dos efeitos concorrenciais da conduta.

Não foi este, porém o entendimento da SG, segundo a qual não estaria ela autorizada a adentrar questões de mérito da causa, o que resultaria em afronta à competência do Judiciário:

"não é razoável que a autoridade antitruste avalie a fundo fatores apontados pela Vigor quanto ao mérito da causa, como se os radicais "ACTI" e "ACTI" gozariam ou não de proteção específica do INPI, se a silhueta humana aposta nas embalagens da Vigor é ou não parecida com a silhueta utilizada pela Danone, ou ainda se a Danone deteria ou não exclusividade sobre as cores verdes ou magenta, já que isso seria adentrar nas competências do Juízo de julgar o mérito de ação" (BRASIL, 2013e, p. 21-22)

Se a autoridade concorrencial está a analisar uma questão marcária e de concorrência desleal que pode ter efeitos reais ou potenciais sobre a concorrência, necessariamente esbarrará na análise de institutos próprios do direito de PI. O Direito Econômico, enquanto ramo autônomo, pode, para atender aos seus peculiares fins, adentrar na análise das características de institutos e figuras de outros ramos.

Desse modo, entende-se que a autoridade concorrencial tem sim competência para analisar questões de mérito típicas do direito de PI, sem ter que fazer uma análise pela lateral (ou pela tangente) desses institutos ou depender da análise do Poder Judiciário em ações cujos objetivos são alheias à proteção da concorrência enquanto instituição.

\footnotetext{
${ }^{132}$ Testes realizados tipicamente em casos de sham litigation, conforme sumarizados pela SG no caso Pró-Genéricos v. Eli Lilly (BRASIL, 2014f).
} 
Algumas infrações à concorrência podem resultar do abuso ou fraude em procedimentos de registro de marca, que desvirtua a finalidade deste direito de propriedade e acabam por gerar efeitos negativos sobre o mercado.

Nesses casos, pode-se antever duas situações: (a) em uma, o pedido de registro viola expressamente um dispositivo da legislação marcaria (e.g. envolve uma imitação de marca alheia); e (b) em outra, o pedido, ainda que não viole expressamente um dispositivo da LPI, mostra-se contrário à finalidade intrínseca das marcas na promoção da competição entre produtos e/ou serviços, por meio da proteção à reputação do titular contra a usurpação de terceiros e da proteção do consumidor contra confusão. Com relação a essa última hipótese, pode-se citar casos envolvendo pedidos de registros de marcas cujo titular, de antemão, sabe que não pretende comercializá-las seja no curto, seja no longo prazo e, ainda, o pedido de registro de marca notória que não tenha sido previamente utilizada no Brasil.

É possível aventar que a análise antitruste de condutas envolvendo fraudes e/ou abuso de registro perpassaria por uma questão da competência da autoridade antitruste na análise da validade dos registros. Nos termos da LPI, é competência do INPI analisar administrativamente a nulidade do registro de marca, desde que solicitado no prazo de 180 dias contados da data de expedição do certificado de registro (arts. 168 e 169 da LPI). Decorrido esse prazo, a ação de nulidade de registro deverá ser ajuizada perante a Justiça Federal (art. 175 da LPI). Ademais, consoante jurisprudência consolidada do STJ, não é possível a declaração incidental de nulidade de registro, devendo-se ser proposta ação própria nos termos do art. 175 da LPI. ${ }^{133}$ Nesse sentido, caberia a seguinte indagação: cabe ao CADE considerar ilícita uma conduta relativa a um registro que o INPI ou o Poder Judiciário considerou válido?

Aqui retomam-se as considerações do Capítulo 2 sobre a independência das esferas. O fato de o CADE não ter competência para anular registro de marca, ${ }^{134}$ não significa que ele não possa fazer uma análise mais ampla da conduta do agente. $\mathrm{O}$

\footnotetext{
${ }^{133}$ Nesse sentido, Zeloso v. Transall (BRASIL, 2013h)

134 Em Mont Blanc v. Henry Vidigal (BRASIL, 1997) ficou consignado que "o CADE não tem competência para prover qualquer reivindicação com o objetivo de anular um registro" (TIMM, 2009, p. 108)
} 
enfoque da análise do CADE é diferente da análise formalista do INPI. Via de regra, este realizará uma analise formal da marca à luz dos requisitos legais puros. Não considerará elementos mais amplos como o ato do agente vis-à-vis à função social das marcas. O CADE, por sua vez, ao analisar a regularidade da conduta do agente poderá verificar, com mais elementos, se sua ação está em conformidade com a função social do direito que o agente adquiriu ou busca adquirir por meio do registro. Naturalmente, a decisão do CADE não terá qualquer impacto sobre a validade do registro do titular da marca. Nada impede, todavia, que sua decisão seja remetida para o INPI ou Judiciário com determinadas recomendações.

Ademais, conforme ressaltado no item 4.2 acima, o elemento volitivo do agente econômico, o seu plano empresarial ao praticar o ato é um elemento relevante para a análise antitruste que poderá auxiliar o CADE a buscar respostas sobre a regularidade da conduta. Nesse sentido, constatada, por exemplo, a existência de má-fe do agente com posição dominante, a autoridade concorrencial estaria autorizada a prosseguir com a análise dos efeitos reais ou potenciais da conduta sobre o mercado. ${ }^{135}$ 136

A análise de casos envolvendo suposta fraude ou abuso no procedimento de registro de marcas na Europa e no Chile ajuda a elucidar essas questões.

\footnotetext{
${ }^{135}$ A possibilidade de analisar condutas de fraude ou abuso nos procedimentos de registro de PI seja pelo critério da má-fé, seja pelo critério da ação infundada foi reconhecida no caso Nobelpharma $A B v$ Implant Innovations (EUA, 1998).

${ }^{136}$ Note-se que, a despeito de, em todos os casos analisados, os órgãos decisórios terem se pronunciado sobre a possibilidade de efeitos anticompetitivos das fraudes e abusos em procedimentos, não há discussões profundas sobre os efeitos potenciais ou reais da prática e o seu balanceamento com possíveis eficiências derivadas da prática. Embora em Walker, Inc. v. Food Machinery (EUA, 1965), a Suprema Corte tenha afastado a possibilidade de aplicar a regra da ilegalidade per se ao caso, verifica-se que o standard de prova para demonstrar a natureza anticompetitiva da conduta não exigiu um exame elaborado do seu impacto sobre a concorrência. De acordo com a Suprema Corte, seria necessário avaliar o poder exclusionário do pedido ilegal de patente "em termos do mercado relevante do produto envolvido". Em Handgards Inc. v. Ethicon Inc. (EUA, 1984b), a Corte de Apelação asseverou que o requisito relativo à intenção de monopolizar o mercado relevante poderia ser inferido da má-fé e que haveria evidências substanciais no caso para a realização dessa inferência. Além da má-fé e da intenção específica de monopolizar o mercado, a Corte também exigiu que se provasse a existência de "uma probabilidade perigosa de sucesso". Ressaltou, nesse sentido, que prova de poder de mercado tende a dar suporte a essa conclusão. No caso AstraZeneca v Commission (EUROPA, 2012a), essa discussão sobre probabilidade de sucesso também foi de certa forma inserida nas conclusões da ECJ, que afirmou que só haveria abuso, em termos concorrenciais, se, diante do contexto, as representações feitas pela parte para obter ilegalmente direitos de exclusiva, efetivamente tivessem o condão de induzir as autoridades a concedê-los, não sendo necessário prova de efeitos anticompetitivos concretos (apenas potenciais). Em Shop Tour (BRASIL, 2010d), o CADE, embora tivesse constatado que a prática das empresas efetivamente levou à exclusão de concorrentes, esclareceu que o mero risco de a conduta levar ao monopólio já é suficiente para caracterizá-la como anticompetitiva. No caso em tela, o Conselheiro constatou que "ao simular um direito que não o tem, na busca de ludibriar o Judiciário", o autor, "assume uma conduta de risco que pode levar ao monopólio".
} 
a. Europa: o caso Protégé International Ltd. v. Commission

No caso Protégé International Ltd. v. Commission (EUROPA, 2012b), a sociedade Pernod Richard S.A. (PR), atuante na produção e distribuição de destilados e vinhos, e proprietária da marca de whisky "Wild Turkey”, foi acusada de abusar de sua posição dominante no mercado de whisky irlandês ao iniciar processos de oposição, em razão de suposto risco de confusão, contra as marcas de whisky da Protégé Internacional Ltd. (PIL), "Wild Geese", "Wild Geese Rare Irish Whisky" e "Wild Geese Irish Soldiers and Heroes". De acordo com a PIL, essas oposições da PR teriam como objetivo retardar a entrada no mercado dos produtos vendidos sob essas marcas.

Seguindo uma metodologia de análise semelhante à sham litigation, a Corte analisou se (i) havia de fato uma racionalidade subjacente à oposição ao registro de forma que seu pleito não pudesse ser interpretado unicamente como ataque à PIL; e (ii) se esta conduta tinha por objetivo eliminar a concorrência no mercado. ${ }^{137}$

Nesse passo, a Corte verificou que não era possível estabelecer a existência de uma infração, em especial, diante da dificuldade de se demonstrar que os processos de oposição da PR eram objetivamente infundados. As alegações de confusão entre as marcas não eram totalmente imotivadas, uma vez que foi constatada certa semelhanças entre ela. Ademais, a ECJ concluiu que os efeitos da conduta no mercado comum europeu não estavam bem definidos. ${ }^{138}$

Trata-se de um caso, portanto, em que se nota uma preocupação da ECJ de não privar um agente econômico de exercer direitos legítimos no âmbito da legislação marcária (i.e. opor registros de marcas supostamente não registráveis) - uma vez que há, de fato, uma análise da fundamentação do pleito com base na legislação

\footnotetext{
${ }^{137}$ Nos termos do parágrafo 49 da decisão: "afin de conclure qu'une action en justice peut constituer, en réalité, un abus de position dominante, deux conditions cumulatives doivent être réunies. En premier lieu, il faut que l'action ne puisse être raisonnablement considérée comme visant à faire valoir les droits de l'entreprise en cause et ne puisse dès lors servir qu'à harceler la partie adverse. En deuxième lieu, l'action doit être conçue dans le cadre d'un plan ayant pour but d'éliminer la concurrence [...]. Ces deux conditions doivent être interprétées et appliquées restrictivement, de manière à ne pas tenir en échec l'application du principe général d'accès au juge [...]" (EUROPA, 2012b), .

${ }^{138}$ Com relação a esse ponto, a ECJ recordou que, segundo jurisprudência consolidada, é a gravidade da alegada prática sobre a concorrência e a persistência dos seus efeitos e, em particular, sua duração, importância e impacto na concorrência dentro da União Europeia que são analisados no âmbito do Direito Concorrencial e não o tamanho das empresas que supostamente cometeram a violação.
} 
pertinente - ao mesmo tempo em que se busca estabelecer de forma clara os contornos de atuação da legislação concorrencial.

b. Chile: o caso FNE vs. CCU

O desenho da legislação marcária de países membros da OMC, tal como autorizada pelo TRIPS, possui algumas brechas facilitadoras de ações anticompetitivas.

Nesse ponto, destaca-se o artigo 15.3 deste Acordo, ${ }^{139}$ que possibilita o registro de marca sem que seu titular efetivamente dela faça uso (BASSO, 2000, p. 212). ${ }^{140}$ Essa válvula de escape pode resultar em distorções no mercado na medida em que um agente com posição dominante a utilize para erigir barreiras à entrada, impedindo a atuação regular de novos agentes sobre o mercado. ${ }^{141}$

Nesse sentido, interessante mencionar o caso chileno FNE v. CCU (CHILE, 2013), no qual importante grupo cervejeiro (CCU) foi acusado de registrar uma série de marcas que eram utilizadas por concorrentes no exterior, sem que delas efetivamente fizesse uso no território chileno, e, assim, gerar prejuízos ao mercado. ${ }^{142}$

\footnotetext{
${ }^{139}$ TRIPS, art. 15.3: "Os Membros poderão condicionar a possibilidade do registro ao uso da marca. Não obstante, o uso efetivo de uma marca não constituirá condição para a apresentação de pedido de registro. Uma solicitação de registro não será indeferida apenas com base no fato de que seu uso pretendido não tenha ocorrido antes de expirado um prazo de três anos, contados a partir da data da solicitação."

${ }^{140}$ Mesmo nas situações em que a legislação nacional condicione a manutenção do registro ao uso da marca, o TRIPS estabelece, em seu artigo 19.1, que o cancelamento do registro só será possível após decorrido um prazo ininterrupto de, pelo menos, 3 (três) anos de não uso e, desde que o titular não demonstre motivos válidos, alheios a sua vontade, baseado na existência de obstáculos a esse uso.

${ }^{141} \mathrm{O}$ registro de uma marca sem finalidade imediata de uso também poderia refletir um comportamento estratégico de uma empresa, que, antecipando-se à comercialização de um produto ainda em desenvolvimento, registra uma marca que, na sua visão, melhor distinguirá o produto de outros que venham a ser comercializados por seus concorrentes. Nesse aspecto, porém, não se antevê prejuízos concorrenciais. Sobretudo em casos envolvendo produtos em desenvolvimento ou expectativas de oportunidades de negócio, o registro antecipado de uma marca, sem seu uso imediato, a princípio, revelase legítima e em consonância com a chamada "competition on the merits".

${ }^{142}$ Em 2013, a FNE havia apresentado uma denúncia contra a CCU, imputando a essas empresas uma série de atos anticompetitivos no mercado de cervejas, consistentes na (i) manutenção de registros de marcas, sem que estas fossem efetivamente utilizadas, os quais correspondiam a marcas comercializadas por concorrentes atuais ou potenciais da CCU, em geral, no exterior; (ii) manutenção de registros marcários que correspondiam a variedades genéricas de cervejas e que serviam para distinguir diferentes tipos de cerveja; (iii) manutenção de registros marcários sem comercializar os produtos a eles associados e que correspondiam a indicações geográficas do Chile que permitiam diferenciar o lugar de origem do produto. Duas empresas cervejeiras, a Cervecería Chile S.A. (CCH) e a Bavaria S.A. (Bavaria) apoiaram a denúncia da FNE e apresentaram manifestações complementares, relatando que a CCU havia registrado marcas detidas por aquelas empresas no exterior e tomado uma série de medidas judiciais e administrativas para impedi-las de comercializar essas marcas no país. A $\mathrm{CCH}$ apresentou denúncia contra a CCU, pois esta teria (i) bloqueado artificialmente o ingress no mercado nacional da cerveja
} 
A legislação chilena não condiciona o registro da marca ao efetivo uso, de modo que inexiste meios legais de cancelar os registros ou de se alegar sua caducidade pelo não uso da marca.

Diante disso, a parte demandada alegou que a FNE, buscava, por meio do Direito da Concorrência, alterar o conteúdo da legislação marcária na medida em que pretendia impor o uso efetivo como condição para a titularidade da marca, contrariamente ao que dispunha a legislação chilena.

A FNE, por sua vez, defendeu que, quando essa falha legislativa é aproveitada por agente com posição dominante, com o propósito de excluir concorrentes do mercado e criar barreiras ao seu ingresso, ela deve ser sancionada pelo Direito Antitruste. $^{143}$

Para a autoridade chilena, o caráter exclusionário da conduta do CCU poderia ser verificado sob a perspectiva de aumento de custo de rivais e sob uma "perspectiva reputacional”, na qual a agressividade das condutas do agente com posição dominante é sinalizada ao mercado, inibindo potenciais retaliações de rivais.

No primeiro caso, o aumento dos custos dos rivais poderia se materializar de, pelo menos, três maneiras, segundo a FNE: (a) custos de recuperação das marcas; ${ }^{144}$ (b) custos associados à demora durante o processo de recuperação; ${ }^{145}$ e (c) custos significativos com criação de novas marcas. ${ }^{146}$

\footnotetext{
"Andes" e (ii) feito ameaças e tomado medidas judiciais e administrativas destinadas a dissuadir a CCH de importar e comercializar a cerveja "Andes" no Chile. Além disso, a Bavaria apresentou manifestação reportando que a CCU havia registrado no Chile as marcas "Aguilla" - tradicional marca de cerveja detida pela Bavaria no exterior, e a marca "Pony Malt", muito similar à marca "Pony Malta", detida pela Bavaria em relação a uma bebida popular de malte, originária da Colômbia. Com isso, a CCU teria impedido que os verdadeiros titulares das marcas pudessem comercializar os respectivos produtos e posicionar-se no mercado mexicano.

143 "La conducta de las Requeridas ha sido posible, en parte, producto de las fallas de la Ley No 19.039 , de Propiedad Industrial (...) y los incentivos que esas fallas otorgan. En efecto, al tratarse de un mecanismo de bloqueo de muy bajo costo, no contemplar la LPI requisitos o exigencias de uso efectivo de las marcas inscritas y/o renovadas, ni tampoco una sanción de caducidad asociada a ese no uso, en los hechos esa regulación otorga incentivos para registrar y acaparar marcas con una finalidad exclusoria. Precisamente, cuando el aprovechamiente de esa falla es efectuado por un actor dominante, como es el caso de autos, tal comportamiento debe ser sancionado en sede de la libre competencia" (CHILE, 2013, p. 16-17).

${ }^{144}$ Segundo a FNE, "[L]os terceros que deseen hacer uso de sus marcas para comercializar y publicitar activamente los productos asociados a ellas deberán pagar al grupo CCU los montos que éste les exija para transferir las marcas qe aquellos comercializan en el extranjero o, en el extremo, deberán intentar una acción de nulidad ante el INAPI" (CHILE, 2013, p. 19).

${ }^{145}$ Para a FNE, "[D]urante la tramitación del juicio de nulidad marcaria, el competidor que desea recuperarla no podrá comercializar intensamente, o al menos publicitar, esos productos, bajo amenaza de acciones civiles, criminales y administrativas por parte del grupo $\mathrm{CCU}$, incluyendo posibles comisos por
} 
No segundo caso, o fato de a CCU adotar medidas judiciais, civis e criminais, e medidas administrativas contra concorrentes, bem como envio de comunicações denigritórias a seus clientes sinalizaria um reação agressiva contra os atores que desejassem comercializar seus produtos. Em outras palavras, a CCU teria criado uma reputação de incumbente agressivo, inibindo a reação de concorrentes.

Em 2014, o contencioso terminou em acordo, por meio do qual a CCU comprometeu-se a tomar uma série de medidas com relação às marcas cuja situação havia sido questionada pelos denunciantes. Nesse contexto, a CCU comprometeu-se a cancelar perante a autoridade de propriedade industrial chilena os registros de certas marcas se não as utilizasse dentro da categoria em que foram registradas. Além disso, desistiu de solicitar o registro de outras marcas que estavam pendentes. Por fim, transferiu para a concorrente Bavaria o registro de marcas que originalmente pertenciam a esta empresa no exterior. ${ }^{147}$

Com efeito, da análise do caso, é possível perceber que determinadas válvulas de escape da legislação marcária podem resultar em comportamentos anticompetitivos. Embora a lei chilena permita o registro da marca (e sua manutenção) sem sua utilização efetiva, fato é que essa brecha pode ser usada de maneira oportunista por empresas com posição dominante. Dessa maneira, constatada a má-fé no comportamento do agente e, ainda, efeitos adversos sobre a concorrência, a conduta seria passível de punição sob a perspectiva do Direito Antitruste, ${ }^{148}$ sobretudo porque

parte del Servicio Nacional de Aduanas. Lo anterior, junto con eventuales comunicaciones de las Requeridas a clientes de competidores, con los posibles efectos sobre la reputación de éstos. Incluso más, las Requeridas podrán seguir solicitando las renovaciones de ese registro, conforma a las reglas generales de la LPI. Según antecedentes recabados por esta Fiscalía, litigios de esta naturaleza pueden tener una duración mínima de cuatro años y medio, sólo ante el INAPI" (CHILE, 2013, p. 19).

${ }^{146}$ De acordo com a FNE, "[L]as conductas de las Requeridas levarían en la practica a que potenciales interesados en comercializar y publicitar acivamente las marcas comerciales afectadas dentro del país, tendrían que destinar recursos especiales a la creación de nuevas marcas, un nuevo etiquetado de productos y la realización de campañas publicitarias específicas para el mercado chileno, en perjuicio de la eficiencia productiva de esos actores. La misma situación ocurriría en caso de que teniendo otras marcas en su portfolio, esos interesados deban ingresar al mercado o expandir su operaciones con aquellas que no necesariamente se ajusten a la maior opción comercial de la empresa" (CHILE, 2013, p. 19).

${ }^{147}$ No caso das marcas que fazem alusão a áreas geográficas, o acordo estabeleceu que a CCU renunciaria ao direito de opor-se a terceiros quando estes utilizem essas palavras de maneira acessória a outra marca com a finalidade de indicar a origem de um produto. Por último, a CCU comprometeu-se a cancelar os registros daquelas marcas que denotavam uma variedade genérica de cerveja (e.g. Ambar, Bock, Bock la Cerveza del Invierno, Bock 6.0, Clara, Clarita, Lager y Porter. Ademais, obrigou-se a renunciar a diversas marcas iguais ou similares àquelas detidas por concorrentes no exterior (e.g. Keller, Pacífico, Paquiña y Taquiña).

${ }^{148}$ No Brasil, nos termos do art. 143 da LPI, “caducará o registro, a requerimento de qualquer pessoa com legítimo interesse se, decorridos 5 (cinco) anos da sua concessão, na data do requerimento: I - o uso da 
está inserida num contexto em que o ato do agente distorce a finalidade precípua da marca de promoção de competição entre as empresas. Se a marca será inutilizada, não se lhe está dando qualquer destino útil, o que contraria sua função social e econômica.

\section{Práticas discriminatórias envolvendo o uso de marcas de certificação}

As práticas discriminatórias, seja no âmbito de acordos verticais, seja no âmbito de acordos verticais, têm por objetivo a eliminação de oposição de interesse de terceiros. Seu potencial lesivo está na vantagem que confere a um concorrente em detrimento dos demais (SALOMÃO FILHO, 2007).

No que tange à intersecção entre direito marcário e antitruste, problemas podem ser encontrados, por exemplo, quando há um uso indevido de uma marca de certificação por associações com o propósito de excluir concorrentes que não são associados a ela.

A marca de certificação é aquela usada para atestar a conformidade de um produto ou serviço com determinadas normas ou especificações técnicas, notadamente quanto à qualidade, natureza, material utilizado e metodologia empregada. Seu propósito é "informar ao público que o produto ou serviço distinguido pela marca está em desacordo com as normas ou padrões técnicos específicos” (BRASIL, 2012b, p. 6). Quando a finalidade dessa marca é desvirtuada (e.g. transmita informações falsas para os consumidores), poderá existir um problema concorrencial a depender das circunstâncias específicas do caso, dos agentes que a veiculam e do mercado.

No recente caso do cartel dos cimentos (BRASIL, 2014h), membros da Associação Brasileira de Cimento Portland (ABCP) foram condenados do ponto de vista concorrencial por, dentre outros fatores, desvirtuarem o significado de uma marca de certificação, o que tinha o condão de impedir o desenvolvimento de concorrentes que não integravam a associação.

marca não tiver sido iniciado no Brasil; ou II - o uso da marca tiver sido interrompido por mais de 5 (cinco) anos consecutivos, ou se, no mesmo prazo, a marca tiver sido usada com modificação que implique alteração de seu caráter distintivo original, tal como constante do certificado de registro." Nesse sentido, a situação ocorrida no Chile muito provavelmente não encontraria substrato legal no Brasil que permitisse sua ocorrência. 
De forma mais detalhada, os membros da ABCP buscaram, sem qualquer fundamentação técnica razoável, mudar as normas técnicas da ABNT para torná-las mais restritivas e, assim, fazer com que os misturadores (concorrentes dos cimenteiros) ficassem "fora da norma". O propósito aqui era claramente exclusionário na medida em que a mudança das normas não visava, de acordo com as evidências dos autos, à melhoria da qualidade do produto, mas apenas à criação de barreiras à atuação dos misturadores. $^{149}$

Uma vez atingido o objetivo de alteração das regras da ABNT, a ABCP elaborou um "Alerta aos Consumidores de Cimento" e o veiculou em diversos sites de associações e sindicatos do setor com o objetivo de chamar a atenção dos consumidores sobre os "riscos" associados ao uso de cimento "fora de norma" e indicar quais seriam as marcas que estariam desconformes, bem como aquelas de boa qualidade, "de sólidos grupos cimenteiros", que, na realidade, faziam parte da ABCP.

Em seguida, a ABCP (BRASIL, 2014h, p. 215-216) criou um "selo de qualidade”, aqui entendido como uma espécie de marca de certificação (se é que, de fato, não o era), que basicamente era concedido apenas aos seus associados, proliferando a ideia ao mercado de que apenas aquelas detentoras do selo estariam aptas a produzir cimento de boa qualidade. Conforme explica o Conselheiro Márcio de Oliveira Júnior, “a política de selos, em princípio, pode ser eficiente do ponto de vista antitruste desde que não crie barreiras artificiais a agentes que estejam aptos a obtê-lo e que não seja objeto de manipulação negativa da imagem de concorrentes". Dada o histórico no qual as regras da $\mathrm{ABNT}$ foram indevidamente alteradas, restou claro para o CADE que o foco do selo não era o consumidor, mas sim beneficiar os associados da $\mathrm{ABCP}$ e, por conseguinte, excluir os demais concorrentes do mercado, prejudicando a concorrência.

\footnotetext{
${ }^{149}$ Em seu voto-vista, o Conselheiro Márcio de Oliveira Júnior (BRASIL, 2014h, p. 215) esclarece que "após conseguir deixar os cimentos das associadas dentro da norma e os cimentos dos concorrentes fora da norma, seria possível montar uma suposta relação de causalidade no seguinte sentido: se o cimento está fora de norma, logo não é de qualidade. No entanto, esquece a associação de avisar que, dos presentes à votação de aprovação, pelo menos $42 \%$ dos votos colhidos eram associados da $\mathrm{ABCP}$. Ou seja, as minorias eram sufocadas pelas associadas. Logo, como não havia debate efetivo da ABTN, as associadas impunham a configuração de produto que melhor lhes aprouvera e não as configurações de fato benéficas ao consumidor".
} 
Práticas empresariais no contexto de licenciamentos de marcas não estão isentas do controle antitruste. Com relação a esse ponto, o art. 40 do TRIPS ${ }^{150}$ prevê que os contratos de licença não podem ter por objeto nem por efeito impedir, falsear ou restringir a concorrência.

Em se tratando o licenciamento de marcas de uma forma contratual por meio da qual o titular de uma marca atribui a um terceiro o direito de referenciar, através dela, os seus próprios produtos ou serviços e de utilizá-la em sua própria atividade econômica, o controle da qualidade da marca pelo seu titular é uma questão crucial nesse tipo de relação. O consumidor deve poder confiar em um padrão de qualidade consistente atrelado à marca. O seu titular, por sua vez, tem interesse em manter este padrão e, consequentemente, o valor de sua marca (OLAVO, 2005).

Esse ponto é fundamental para compreender o tipo de análise empreendida pela autoridade concorrencial. Os limites da atuação do titular da marca são avaliados na medida em que atendam ou não à finalidade econômica do contrato de licenciamento.

Em geral, todavia, do ponto de vista antitruste, os contratos de licenciamento de marcas ensejam menos preocupação do que os contratos de licenciamento de patentes.

Considerando que as patentes podem estar relacionadas a uma tecnologia essencial, da qual um terceiro pode depender para desenvolver um novo produto ou mesmo atuar num mercado secundário, questões concorrenciais podem ser levantadas

\footnotetext{
150 TRIPS, art. 40: "1. Os Membros concordam que algumas práticas ou condições de licenciamento relativas a direitos de propriedade intelectual que restringem a concorrência podem afetar adversamente $o$ comércio e impedir a transferência e disseminação de tecnologia. 2. Nenhuma disposição deste Acordo impedirá que os Membros especifiquem em suas legislações condições ou práticas de licenciamento que possam, em determinados casos, constituir um abuso dos direitos de propriedade intelectual que tenha efeitos adversos sobre a concorrência no mercado relevante. Conforme estabelecido acima, um Membro pode adotar, de forma compatível com as outras disposições deste Acordo, medidas apropriadas para evitar ou controlar tais práticas, que podem incluir, por exemplo, condições de cessão exclusiva, condições que impeçam impugnações da validade e pacotes de licenças coercitivas, à luz das leis e regulamentos pertinentes desse Membro (...)".
} 
com mais frequência. De fato, casos emblemáticos julgados por autoridades estrangeiras envolviam recusas de licenciamento de patentes. ${ }^{151}$

No caso das marcas, em geral, dificilmente haverá a ideia de um bem ou serviço essencial, porque a marca, diferentemente da patente, não está intrinsicamente ligada a uma tecnologia, mas sim a um conceito, uma ideia sobre um produto ou serviço.

Ainda assim, algumas questões concorrenciais poderão surgir no licenciamento de marcas sobretudo em casos em que um detentor de posição dominante imponha condições abusivas para o licenciamento de sua marca, num contexto em que haja certa dependência dos agentes econômicos com relação ao produto comercializado ou serviço prestado pelo titular da marca.

Nesse ponto, o caso DSD v. Commission (EUROPA, 2009b), julgado pela Corte Europeia, é bastante elucidativo. Nele uma empresa prestadora de serviços cuja contratação era obrigatória por força de normas de direito ambiental foi condenada por impor um sistema de remuneração abusivo e desproporcional em seus contratos de licenciamento de marca, que tinha por efeito restringir a entrada de novos concorrentes no mercado na medida em que desincentivava a contratação de serviços de concorrentes. $^{152}$

\footnotetext{
${ }^{151}$ Image Technical Services, Inc. v. Eastman Kodak Co. (EUA, 1997); In Re Independent Service Organizations Antitrust Litigation v. Xerox Corporation (EUA, 1981); Microsoft (EUROPA, 2004a); e Microsoft v. Commission (EUROPA, 2007).

${ }^{152} \mathrm{Na}$ Alemanha, por força da legislação ambiental, os produtores e distribuidores de determinados produtos eram obrigados a adotar mecanismos de coleta e reciclagem de embalagens, seja diretamente, seja por meio de terceiros. A empresa Der Grüne Punkt - Duales System Deutschland GmbH ("DSD"), por sua vez, era a única empresa na Alemanha capaz de oferecer um serviço completo de coleta e reciclagem das embalagens em âmbito nacional. Por meio de um acordo de licenciamento de marcas, a DSD exigia que todos os produtores e distribuidores afixassem nas embalagens de seus produtos o logo da DSD denominado "Green Dot". A remuneração pelo uso da marca era baseado no volume total de embalagens postas em comercialização e não o volume de embalagens efetivamente coletadas e recicladas pelo sistema da DSD. Para a Comissão Europeia, o fato de os produtores e distribuidores terem de efetuar um pagamento que tinha por base o volume total de embalagens comercializadas e não o volume de embalagens coletadas e recicladas pelo sistema da DSD era abusivo e tinha por efeito desincentivar a entrada de concorrentes no mercado, uma vez que era financeiramente desvantajoso para as empresas contratar outra empresa de coleta de embalagens. Considerando que a DSD detinha posição dominante no mercado ora analisado, a Comissão Europeia entendeu que o sistema de precificação do acordo de licenciamento de marcas refletia um abuso de posição dominante. De acordo com a decisão, ele representava um "exploitive abuse" e um "obstructive abuse". O primeiro tipo de abuso faz referência aos preços e termos e condições não-razoáveis e desproporcionais impostos pelo acordo de licenciamento, os quais, são desconectados da efetiva utilização dos serviços de coleta e reciclagem de embalagens. Para a Comissão Europeia, "[U]nfair commercial terms exist where an undertaking in a dominant position fails to comply with the principle of proportionality" (para. 112) . O segundo tipo de abuso, por sua vez, diz respeito à restrição causada à entrada de concorrentes no mercado. De acordo com a Comissão Europeia, uma empresa com posição dominante pode impedir a entrada de concorrentes ao vincular, legalmente ou
} 
Em geral, todavia, os contratos de licenciamento geram eficiências prócompetitivas. Para o licenciante, permite o melhor aproveitamento econômico do sinal, aumenta a projeção e notoriedade do símbolo sobre os consumidores e, consequentemente, possibilita a maior difusão dos produtos ou serviços a que é aposta. Para o licenciado, permite-lhe beneficiar da projeção da marca e da experiência adquirida por terceiro (OLAVO, 2005, p. 143).

Nesse sentido foi o julgamento da Corte de Apelação do Segundo Circuito dos Estados Unidos no caso Major League Baseball v. Salvino (EUA, 2008a). No caso, o Major League Baseball Enterprises, Inc. (MBLE) controlava empresa responsável pelo licenciamento exclusivo de todos os nomes, logos e marcas de clubes de baseball, ${ }^{153}$ os quais, por sua vez, detinham participações na MBLE.

Esta empresa foi acusada de reduzir a concorrência entre os clubes, uma vez que a receita advinda do licenciamento das marcas dos clubes era dividida de forma equitativa entre os membros, apesar de apenas um número reduzido de clubes contribuir para a maior parcela da receita. Alegava-se que essa sistemática de remuneração

de fato, os seus clientes aos seus serviços e, assim, prevenir que eles utilizem fornecedores concorrentes. Nesse sentido, um sistema de concorrência livre somente é garantido quando as oportunidades são asseguradas a todos os agentes econômicos. Essa igualdade de oportunidade, segundo a jurisprudência europeia, é particularmente importante para entrantes em um mercado onde a competição já é enfraquecida pela presença de uma empresa com posição dominante e outros fatores (para. 114). No caso concreto, a Comissão Europeia entendeu que a forma de precificação do acordo de licenciamento desincentivava a contratação de serviços de concorrentes, e, portanto, não garantia oportunidades iguais aos agentes do mercado. A DSD contestou a decisão da Comissão Europeia, alegando, sob uma perspectiva de direito marcário, que a modificação do seu sistema de precificação para um que permitisse que empresas concorrentes coletassem e reciclassem embalagens que carregassem o logo "Green Dot" enfraqueceria o poder identificador da marca, na medida em o publico não mais entenderia que o símbolo significa que a embalagem poderia ser coletada pelo sistema da DSD. A Comissão Europeia, destacando julgados anteriores, ressaltou que o exercício de um direito de exclusiva é proibido quando enseje conduta abusiva por parte de uma firma com posição dominante. Nesse contexto, "[T]he crucial point is whether the conduct goes beyond what is necessary to fulfil the essential function of the exclusive right as permitted in Community law" (para. 144). Assim, ao analisar se a conduta ultrapassa o que é necessário para cumprir com a função essencial da marca "Green Dot", a Comissão concluiu que a função essencial da marca Green Dot era preenchida na medida em que sinalizasse ao consumidor que ele tem a opção de ter suas embalagens coletadas pela DSD. Dessa maneira, a coleta e reciclagem de embalagens com o logo "Gree Dot", ainda que realizada por concorrentes, não traria prejuízos à marca. A Corte Europeia, ao rever, a decisão da Comissão, entendeu que esta estava correta ao declarar abusiva a forma de cobrança da licença. Ademais, considerou que a decisão apelada também não infringia a legislação marcária. Segundo alegado pela DSD, a decisão da Comissão, ao proibi-la de adotar um sistema de precificação baseada não na quantidade de embalagens comercializadas com o símbolo "Green Dot", mas sim na quantidade que era efetivamente coletada e reciclada pelo sistema DSD, significava, em termos práticos, que ela teria de licenciar a sua marca gratuitamente para terceiros. A Corte Europeia ressaltou que a aposição da marca "Green Dot" em todas as embalagens comercializadas por seus fornecedores era uma exigência contratual da própria DSD. O único propósito da decisão da Comissão Europeia era impedir que a DSD auferisse pagamentos por serviços que não prestou.

${ }^{153}$ Essas marcas eram apostas em produtos de entretenimento (ursos de pelúcia, brinquedos, camisetas, bonés, embalagens de alimentos, etc.). 
desencorajava os clubes principais da liga a investir, promoverem seus produtos e competirem por meio de suas marcas.

O tribunal entendeu que a conduta não violava a legislação concorrencial, uma vez que o licenciamento centralizado e o sistema de remuneração dos clubes resultava em eficiências pró-competitivas.

Nesse sentido, considerou que, uma vez que a MLBE era uma entidade de esporte profissional altamente integrada que promovia importantes eventos esportivos onde todos os clubes membros competiam, era importante que fosse mantido um equilíbrio competitivo entre os clubes para que os torneios promovidos pela empresa mantivessem sua popularidade. O sistema de remuneração compartilhado dos contratos de licenciamento, concluiu o tribunal, era orientado para atingir esse objetivo e, portanto, não poderia ser considerado anticompetitivo. ${ }^{154}$

O caso consagra, portanto, o caráter pró-competitivo do licenciamento de marcas. Situações que configurem infrações à concorrência exigem circunstâncias específicas, geralmente atreladas à essencialidade do produto a que a marca está relacionada.

\section{Predação via diferenciação por marcas}

A predação é um termo genérico utilizado para designar vários tipos de condutas por meio das quais um agente com posição dominante "incorre em prejuízos na expectativa de eliminar o concorrente do mercado, esperando recuperar posteriormente, através de diversas formas, o montante perdido" (SALOMÃO FILHO, 2007, p. 159).

Em teoria, é possível aventar que, em representando a marca uma barreira à entrada, ela poderia ser utilizada por agentes com posição dominante para

\footnotetext{
${ }^{154}$ No caso, os clubes têm uma forte relação de interdependência, que é fundamental para a manutenção não somente da popularidade do time em si, mas também para a manutenção e viabilidade da existência das ligas. Um sistema de licenciamento que permitisse os principais clubes a ganharem mais porque suas marcas são objeto de um maior número de licenças interferiria nesse equilíbrio competitivo entre os clubes. No entender do tribunal, em última instância, todos os clubes contribuem igualmente para o sucesso da liga e dos eventos esportivos, havendo racionalidade no sistema de remuneração dos contratos de licenciamento.
} 
impedir a entrada ou o desenvolvimento de concorrentes. Trata-se aqui, especificamente, de três hipóteses:

(a) a proliferação de marcas (brand proliferation), por meio da qual o agente dominante detém e comercializa diversas marcas para produtos em diversos nichos de um mesmo mercado, em tese, minando as possibilidades de concorrência de terceiros;

(b) marcas de combate (brand preemption), consistente na estratégia de introduzir marcas antes da entrada de um agente econômico para combater sua entrada no mercado; e

(c) realização de elevados investimentos em marcas, aumentado as barreiras à entrada de concorrente.

Dada a ambiguidade dos efeitos da conduta de predação, Salomão Filho (2007, p. 174) entende que sua análise deve ser pautada por um critério objetivo - a primazia do valor concorrência. Dessa maneira, explica que, uma vez que a teoria jurídica não se contenta com a mera verificação dos efeitos econômicos, exige a verificação de um comportamento que tenha o condão de causar prejuízo à concorrência, "que pode ser definido como todo comportamento não justificado por um propósito empresarial específico e que só se revele conveniente para a empresa caso desapareça a concorrência. A antijuricidade está, portanto, não mais apenas no resultado puro, mas naquela conduta direcionada a um resultado e que tenha a capacidade de atingi-lo".

No caso específico das marcas, é muito difícil estabelecer esse propósito empresarial anticompetitivo justamente porque está na essência da diferenciação por marcas a estratégia de direcionar as aquisições do consumidor por meio da fidelização à marca, o aumento de vendas e o desvio de demanda de produtos concorrentes. A estratégia agressiva via diferenciação é o padrão normal do mercado capitalista. Não por outra razão, o guru de marketing, David Aaker (2011), ensina, em seu livro sobre relevância da marca, como "making competitors irrelevant".

Diferentemente do caso das patentes, a inovação via marcas consegue ser mais célere e dinâmica, já que, para a divulgação de uma nova marca, o produto não tem que sofrer qualquer modificação, não tem de ser inovador, basta que a publicidade em torno da marca convença o consumidor de que o produto é a melhor opção. Nesse cenário, a posição do agente com posição dominante que seja titular da marca é muito 
mais instável e a possibilidade de exercer de forma abusiva sua posição dominante é menor.

Como explica Semprini (2010), as marcas possuem uma dimensão dinâmico-mutável, que as colocam constantemente em cheque: devem manter sua relevância em um mercado dinâmico; do contrário, tornam-se ultrapassadas e não representam qualquer ameaça ao ambiente competitivo. ${ }^{155}$

Em um mercado em constante mudança, manter consumidores interessados em e leais à determinada marca, não é tarefa fácil. Exige habilidade, investimentos e capacidade de inovação. O contexto dinâmico e evolutivo no qual a marca está envolvida a obriga a um trabalho contínuo para manter a sua posição dominante e as vantagens conquistadas. Como aponta Semprini (2010, p. 112), "no universo das marcas pós-modernas, o sucesso alimenta o sucesso, mas se alimenta também e sobretudo, de investimentos, de ideia, de criatividade, de audácia"

Nesse sentido, embora a marca tenha a capacidade de tornar concorrentes irrelevantes e criar barreiras à entrada e desenvolvimento de rivais no mercado, trata-se de um processo relativamente instável, na medida em que a marca é constantemente desafiada pelo dinamismo do mercado e sua relevância é ameaçada seja por processos internos (i.e. habilidade de renovar-se e manter-se atualizada com as tendências de mercado e de consumo), seja por processos externos (i.e. inovações de concorrentes).

Nesse passo, quando não haja uma patente irregularidade no uso da marca (e.g. afronta direta aos dispositivos da LPI), a probabilidade de que haja decisões sancionatórias do por parte da autoridade concorrencial que incorra em erro tipo II (sancionar quando a firma é inocente) é muito grande. A análise da jurisprudência mostra uma tendência pela não condenação de práticas agressivas em que a marca é o principal instrumento quando não haja uma abusividade patente no seu uso.

\section{a. Proliferação de marcas (brand proliferation)}

No âmbito do direito antitruste, a estratégia de proliferação de marcas ou brand proliferation poderia, em teoria, refletir uma conduta predatória, por meio da qual

\footnotetext{
${ }^{155}$ Como explica Aaker, "a brand loses by failing to maintain relevance, by becoming yesterday's
} brand" (2011, p. 301). 
um agente com posição dominante inundaria o mercado com marcas de sua titularidade de maneira a fechar nichos disponíveis e inviabilizar a entrada de concorrentes (CHURCH e WARE, 2000, p. 14).

A configuração dessa conduta como uma infração à ordem econômica, todavia, encontra dois problemas adicionais àqueles expostos no item (i) acima. Em primeiro lugar, considerando que a propriedade sobre a marca é assegurada pela Constituição Federal, não estariam as empresas livres para registrarem quantas marcas entenderem necessárias para jogar o jogo da competição? Em segundo lugar e, nesta mesma linha, não estaria a autoridade concorrencial extrapolando os limites de seu poder interventivo ao pretender regular a quantidade ótima de marcas que certo mercado deve ter?

Diante dessas questões e da dificuldade de se provar a infração, são raros os casos de brand proliferation que efetivamente chegaram à análise de autoridades.

Com efeito, foi localizado apenas um caso antigo nos EUA: o caso Cereals. Em 1972, o Federal Trade Commission (FTC) apresentou uma denúncia contra os quatro maiores produtores de cereais matinais - Kellogg, General Mills, General Foods e Quaker Oats, que juntos detinham cerca de $91 \%$ do mercado (ESTADOS UNIDOS, 1982).

De acordo com o FTC, essas companhias teriam explorado sua posição de mercado e erigido barreiras insuperáveis à entrada, por meio da excessiva diferenciação de produtos, proliferação de marcas e publicidade. Essas empresas detinham, em conjunto, cerca de 150 marcas, que buscavam diferenciar os cereais sobretudo tendo em vista aspectos de cor e forma. Ademais, os gastos com publicidade eram altos e tinham triplicado dentro de um período de 20 anos. A ausência de competição entre as empresas decorria, na visão do FTC, de um suposto "monopólio compartilhado" entre elas (SCHMALENSEE, 1978).

Após 10 anos de análise, contudo, o caso foi arquivado. O FTC admitiu que, ausente um "claro comportamento predatório" ou um acordo entre as partes, a teoria do "monopólio compartilhado" não fazia qualquer sentido.

Entende-se que, nesse tipo de situação, a configuração de um comportamento predatório é dificultada, haja vista que a própria Constituição Federal assegura o direito sobre o registro marcas. A própria análise do potencial ofensivo da 
conduta requer que as autoridades concorrenciais façam um diagnóstico da quantidade ótima de marcas que o mercado deveria ter. Afinal, para que a proliferação de marcas seja considerada anticompetitiva, é necessário que se considere que o número de marcas existentes ultrapassou determinada quantia que permite boas condições de concorrência.

Todavia, a assimetria informacional entre as autoridades, de um lado, e o mercado, de outro, leva a crer que esse tipo de decisão tem grandes chances de resultar erros tipo II. As marcas representam um fator primordial de concorrência entre as empresas e sua proliferação pode ser apenas um método legal utilizado pelas companhias para competir, por meio de inovação e diferenciação. Conforme defendido por Boudreaux, "the market itself actually contains a built-in policing mechanism that, if not perfect, is surely less imperfect than the dependence on public officers and the courts" (1990, p. 48).

Portanto, num contexto de proliferação de marcas, pode ser mais adequado confiar na auto-regulação do mercado, que, por si só, eliminará marcas que não sejam suficientemente diferenciadas ou se relacionem a produtos poucos competitivos e com baixa qualidade, do que na regulação promovida por agentes com sérios problemas de assimetria de informação. ${ }^{156}$

b. Marcas de combate (brand preemption)

De maneira genérica, o conceito de marcas de combate é utilizado para designar aquelas marcas que "são lançadas para disciplinar possíveis guerras de preços sem interferir na imagem das marcas premium; e a diversificação de risco do negócio, permitida pela atuação em segmentos com diferentes graus de sensibilidade ao ciclo econômico" (SALGADO, 2008, p. 13).

\footnotetext{
${ }^{156}$ A esse respeito, ressalta Boudreaux (1990, p. 48) que: "It is true that insofar as entry into market is not instantaneous, voluntary consumer responses today might very well lead to net consumer losses in the future. But no public policy can successfully mitigate this problem. Any attempt to guard against net long-term losses would require bureaucrats and the courts to distinguish between consumers that will lead to net reductions in consumer welfare and those that will not. To make such distinctions public authorities would first need an accurate measure of the aggregate net benefit to consumers from today's product innovations or promotional efforts. Then authorities would need to estimate both the the likehood that the nonprice competitive activities will lead to market power and the extent of the market power - its magnitude and duration. Without comparing the consumer benefits of nonprice activities (which we know to be positive_ with the possible future costs of increased market power, neither bureaucrats nor the courts can hope to guard successfully only those nonprice strategies that reduce long-term welfare rather than reduce it".
} 
Aqui, no entanto, utiliza-se o conceito de uma forma mais específica, para designar a estratégia de introduzir marcas antes da entrada de um agente econômico para combater sua entrada no mercado. Esse tipo de comportamento é denominado de "brand preemption” por Church e Ware (2000) e é classificado como uma estratégia dinâmica que envolve um movimento antes que um agente considere a entrada lucrativa.

Nesse contexto, a marca de combate tem uma dupla função: (i) diminuir a possibilidade de diferenciação de concorrentes no mercado; e (ii) posicionar-se antecipadamente no espaço do mercado que poderia ser ocupado pelo entrante. No mais, o lançamento da marca de combate pode ter o fim de depreciar a marca do competidor, na medida em que se faça uma associação com a marca de combate de qualidade e/ou procedência propositadamente duvidosa.

No Brasil, esse tipo de conduta foi analisado em Kaiser vs. Ambev (BRASIL, 2014b). Neste processo, a Ambev foi investigada por ter efetuado suposto ataque à entrada da marca SOL Pielsen no Brasil. Mais especificamente, a AMBEV teria estrategicamente lançado duas marcas de combate, a "Puerto de Sol" e a "Puerto del Mar" com vistas a dificultar a entrada e/ou o fortalecimento da marca SOL, por meio da redução da possibilidade de diferenciação dessa marca e do seu espaço no mercado de cervejas brasileiro.

A SG, seguindo a doutrina de Church \& Ware, considerou que, para que fosse configurado o brand preemption, no mínimo, três requisitos devem ser cumpridos: a marca de combate deveria (i) competir no mesmo segmento que a marca predada; (ii) ser lançada antes do lançamento do entrante; e (iii) eliminar a possibilidade de uma entrada rentável. No caso, todavia, nenhum desses critérios estava presente ${ }^{157}$ de maneira que a SG recomendou o arquivamento da investigação e o TADE a acompanhou.

\footnotetext{
${ }^{157}$ Em primeiro lugar, segundo a SG, as marcas de combate e a marca combatida não estavam dentro do mesmo segmento de mercado, isto é, não competiam entre si. Ao passo que as marcas de combate da AMBEV posicionavam-se no segmento premium de cervejas, a marca combatida da FEMSA ("SOL Pilsen") estava na categoria pilsen. Em segundo lugar, a marca da empresa FEMSA com a qual "Puerto del Sol" e "Puerto del Mar" buscavam efetivamente competir - a "Sol Premium" - já estava no mercado há 16 anos. Em terceiro lugar, a SG entendeu que a entrada das marcas de combate não impedia a consolidação da SOL Pilsen no mercado, pois a FEMSA tinha condições econômicas para neutralizar a estratégia da AMBEV.
} 
Com efeito, percebe-se uma análise cautelosa da SG e do TADE para definir o limite entre condutas com efeitos apenas na esfera privada e estratégias lesivas ao ambiente concorrencial. O ponto de partida da análise da autoridade brasileira foi a de que a introdução de um novo produto, ainda que realizada por um agente monopolista, não pode ser condenável per se, sob a ótica do direito antitruste, o qual deve ter como uma de suas funções o incentivo à inovação (BRASIL, 2013b, p. 32).

Com isso, o ônus de prova foi estabelecido com o devido rigor, ${ }^{158}$ impedindo que uma investigação de natureza antitruste pudesse resultar no beneficiamento indevido de agentes econômicos individualmente considerados.

De fato, o lançamento de marcas integra um processo competitivo natural do mercado na medida em que a diferenciação representa um elemento fundamental da concorrência entre as empresas. ${ }^{159}$ Por essa razão, é grande a preocupação da autoridade concorrencial em não sinalizar erroneamente ao mercado que condutas pró-competitivas ou que não causam lesão à concorrência podem ser punidas. ${ }^{160}$

Nesse sentido, entende-se que a conduta de brand preemption só poderá ser punida sob a ótica concorrencial se ela estiver atrelada a um comportamento abusivo que extrapole os limites do próprio direito marcário. Nesse contexto, o lançamento da marca só seria abusivo se, por exemplo, a marca de combate reproduzisse indevidamente a marca predada ou de alguma forma buscasse implementar uma estratégia de concorrência desleal. De fato, no caso Kaiser vs. Ambev (BRASIL, 2014b), concluiu-se que a Ambev não tinha imputado qualquer fato falso à marca SOL

\footnotetext{
${ }^{158}$ Em seu voto, o Conselheiro Ricardo Ruiz considerou que a representante não tinha apresentado provas de que sua participação de mercado diminuiu após a conduta ou mesmo que sofreu qualquer alteração (BRASIL, 2014b). Esse tipo de constatação corrobora a ideia que a análise dos efeitos nesse tipo de conduta é mais rigorosa.

${ }^{159}$ Nesse sentido, a Procuradoria-Geral Especializada junto ao CADE entendeu que “(...) o lançamento de marcas de combate para contrabalancear a demanda de marcas existentes no mercado, ou que venham a ser lançadas, é prática regular dentro do contexto da livre iniciativa e, de certa forma, decorrente de um mercado em que há concorrência efetiva entre as marcas. A eventual configuração de infração à ordem econômica depende da constatação, no caso concreto, da forma e do modo de lançamento dessas novas marcas" (BRASIL, 2013d).

${ }^{160}$ No caso, o Conselheiro Ricardo Ruiz, em seu voto, considerou que “(...) um ambiente de rivalização é próprio da natureza do jogo competitivo, em que o ganho do concorrente equivale a uma oportunidade de venda perdida para aquele rival. Há que se proceder com cautela quando da demarcação das estratégias empresariais que devem ser consideradas lesivas ao ambiente concorrencial, sob o risco de beneficiar de forma indevida aos agentes empresariais individualmente considerados, que não são objeto imediato de tutela da lei concorrencial. Novamente, portanto, entende-se que os lançamentos das marcas em questão pela Representada embora possa ter sido objeto de discussões privadas relacionadas aos direitos de propriedade intelectual, não tiveram o condão de provocar reduções substanciais nos níveis de concorrência, a ponto de potencialmente afetar a coletividade, não sendo, portanto, passíveis de intervenção antitruste" (BRASIL, 2014b, p. 34).
} 
Pilsen. Ademais, entendeu que não restou comprovada qualquer conduta de concorrência desleal.

Não caracterizado o abuso, a autoridade não deve proceder à análise dos efeitos potenciais dessa conduta sobre o mercado para avaliar a incidência ou não da legislação antitruste.

c. Altos investimentos em marcas

Entende-se que a simples realização de investimentos em marca e publicidade não pode ser vista como uma infração antitruste, não importa quão robustos ou elevados sejam esses investimentos. Conforme ressaltado, estratégias agressivas de diferenciação fazem parte dos padrões normais do mercado capitalista e não deveriam ser punidos pela autoridade concorrencial.

A título ilustrativo, cita-se a decisão do CADE em JBS/Rodopa (BRASIL, 2014a), no qual a autoridade brasileira fez uma extensa análise da transformação pela qual passa o setor frigorífico no Brasil cujas empresas têm-se valido de forte estratégia de construção de marcas como forma de se diferenciar de seus rivais. Faz-se referência ao caso da JBS, que, com a marca Friboi, tem realizado investimentos sem precedentes na construção dessa marca por meio de campanhas publicitárias com o fito de diferenciar-se de seus concorrentes. ${ }^{161}$ A despeito de a estratégia ter possibilitado à empresa praticar preços mais altos, a autoridade reconhece que não cabe a ela criticar esse movimento de diferenciação, uma vez que foi uma vantagem competitiva adquirida licitamente pela empresa. ${ }^{162}$

\footnotetext{
${ }^{161}$ Em seu parecer, a SG ressalta “(...) o crescimento absolutamente sem precedentes dos investimentos em publicidade da JBS em relação aos últimos dois anos. Os gastos da empresa com publicidade simplesmente passaram de RESTRITO vezes mais. É inegável a sua intenção de diferenciar seus produtos e sua marca" (BRASIL, 2014e, p. 77).

${ }^{162}$ Nesse sentido, o voto do Conselheiro Márcio de Oliveira Júnior afirma que: “[A]lém de adquirir novas unidades, faz parte da estratégia da JBS investir para tornar a marca "Friboi" conhecida no mercado, associando a ela a ideia de um diferencial de qualidade. A marca "Friboi" contribui, então, para tornar heterogêneo o mercado brasileiro de carne in natura, até aqui homogêneo. A chegada ostensiva da 'carne de marca', uma novidade em ascensão, poderá permitir a JBS um sobrepreço na venda de carne in natura. A JBS, em função de sua estratégia, adquiriu licitamente uma vantagem competitiva em relação aos demais players, principalmente em relação àqueles que estão na franja do mercado" (BRASIL, 2014a, p. 45). Ademais, o parecer da SG, ao tratar dos crescentes e vultosos investimentos da JBS na marca Friboi, entendeu que “(...) não caberia ao CADE criticar esse movimento, mas é certo que é preciso incorporar
} 


\subsection{Publicidade e marketing: interações com Direito da Concorrência}

\subsubsection{Considerações iniciais}

A análise das estratégias de publicidade e marketing das empresas não poderia ficar de fora de um trabalho que trata da intersecção entre marcas e concorrência. Marca, publicidade e marketing são três temas intrinsicamente relacionados. A marca não teria qualquer visibilidade e praticamente não conseguiria aumentar seu valor sem boas ações de publicidade e uma boa estratégia de marketing.

Dada a relevância da publicidade e do marketing da marca sobre o consumidor e, mais especificamente, sua capacidade de influenciar e mesmo manipular suas decisões de compra, não há dúvidas de que o Direito Antitruste tem um campo grande de estudo nessas duas áreas. A manipulação das decisões de compra do consumidor altera as vendas de uma empresa, o que pode ter impactos sobre o nível de poder de mercado.

No seara da publicidade, a existência de ações enganosas, denigritórias e confusórias afeta de maneira indevida a capacidade de discernimento do consumidor, sua liberdade de escolha e, ainda, pode impedir o desenvolvimento regular dos concorrentes adversamente afetados pela prática. Dessa maneira, o regular fluxo de informações ao consumidor e do comércio é alterado, podendo, ainda, modificar as posições dos agentes econômicos. Assim, quando a publicidade enganosa, denigritória e confusória tenha o condão de alterar a estrutura do mercado, a empresa que a praticou poderá estar sujeita às regras antitruste.

Da mesma maneira, estratégias de marketing que deliberadamente visem a excluir concorrentes ou, ainda, impedir o seu desenvolvimento por meio de ações que objetivem o aumento de custo de distribuição do produto poderão sofrer as penalidades da legislação concorrencial. Tais estratégias podem ser particularmente preocupantes no âmbito do varejo, onde o potencial para atingir o consumidor e afetar as vendas dos agentes econômicos é enorme.

essa nova característica na sua análise concorrencial, como variável de rivalidade, dada sua relevância" (BRASIL, 2014e, p. 77). 
Neste contexto, as seções adiante buscarão tratar com mais detalhes os possíveis efeitos concorrenciais da publicidade enganosa, denigritória e confusória, de um lado, e de estratégias de marketing no varejo, de outro.

\title{
4.5.2. Publicidade enganosa, denigritória e confusória como infração concorrencial
}

\author{
Panorama geral
}

Na sociedade contemporânea, a marca, por si só, não tem muito valor se não for devidamente promovida e "publicizada". Nesse sentido, a publicidade revela-se como um instrumento fundamental e complementar à marca na estratégia de diferenciação do produto que ela referencia.

Tem relação não apenas com a liberdade de expressão comercial e o dever de informação ao consumidor, de um lado, mas também com a livre iniciativa e a livre concorrência, de outro. Nessa linha, ao mesmo tempo em que serve de meio para a divulgação e veiculação do produto - observados certos limites regulatórios, visa à criação de uma demanda ou um direcionamento de mercado para o seu consumo.

Contudo, se utilizada de forma enganosa, a publicidade pode gerar inúmeras consequências adversas no campo do Direito do Consumidor, ${ }^{163}$ do Direito de Propriedade Industrial, ${ }^{164}$ do Direito Civil $^{165}$ e, ainda, do Direito Antitruste. Com

\footnotetext{
${ }^{163} \mathrm{O}$ artigo 37 do CDC proíbe a publicidade enganosa e abusiva: "Art. 37. É proibida toda publicidade enganosa ou abusiva. § $1^{\circ}$ É enganosa qualquer modalidade de informação ou comunicação de caráter publicitário, inteira ou parcialmente falsa, ou, por qualquer outro modo, mesmo por omissão, capaz de induzir em erro o consumidor a respeito da natureza, características, qualidade, quantidade, propriedades, origem, preço e quaisquer outros dados sobre produtos e serviços. $\S 2^{\circ}$ É abusiva, dentre outras a publicidade discriminatória de qualquer natureza, a que incite à violência, explore o medo ou a superstição, se aproveite da deficiência de julgamento e experiência da criança, desrespeita valores ambientais, ou que seja capaz de induzir o consumidor a se comportar de forma prejudicial ou perigosa à sua saúde ou segurança."

${ }^{164}$ A LPI proíbe os atos de concorrência desleal: "Art. 195. Comete crime de concorrência desleal quem: I - publica, por qualquer meio, falsa afirmação, em detrimento de concorrente, com o fim de obter vantagem; II - presta ou divulga, acerca de concorrente, falsa informação, com o fim de obter vantagem; III - emprega meio fraudulento, para desviar, em proveito próprio ou alheio, clientela de outrem; IV - usa expressão ou sinal de propaganda alheios, ou os imita, de modo a criar confusão entre os produtos ou estabelecimentos; V - usa, indevidamente, nome comercial, título de estabelecimento ou insígnia alheios ou vende, expõe ou oferece à venda ou tem em estoque produto com essas referências; VI - substitui, pelo seu próprio nome ou razão social, em produto de outrem, o nome ou razão social deste, sem o seu consentimento; VII - atribui-se, como meio de propaganda, recompensa ou distinção que não obteve; VIII - vende ou expõe ou oferece à venda, em recipiente ou invólucro de outrem, produto adulterado ou
} 
relação a esse último, explica Salomão Filho (2007, p. 85) que "a publicidade é o meio mais fácil e economicamente mais 'barato' de transmissão de informações e de comparação de produtos para os consumidores. (...) Portanto, a concorrência pode ser substancialmente afetada e até falseada pela publicidade enganosa". ${ }^{166}$

Com efeito, tendo o agente econômico poder de mercado, a publicidade ilícita por ele promovida pode ter consequências graves na estrutura do mercado, o que pode ensejar responsabilização do ponto de vista antitruste.

Efeitos anticompetitivos da enganosidade incluem: (i) aumento dos search costs dos consumidores ao escolherem seus produtos; (ii) agravamento da situação do consumidor, que poderá acabar adquirindo um produto com menor qualidade; (iii) aumento do custos de transação de vendedores para diferenciarem seus produtos e recuperarem os ganhos financeiros de sua reputação; (iv) aumento do custo dos concorrentes, que terão de responder a afirmações falsas; (v) aumento das barreiras à entrada a outros produtos; dentre outros (STUCKE, 2010). Ademais, uma vez que veicular informações falsas pode ser mais barato do que desenvolver um produto com qualidade superior, a publicidade enganosa pode ser um método eficiente para ganhar vendas e excluir concorrentes (NEWMAN, 2012).

Nesse sentido, condutas com caráter denegritório, enganoso ou ainda que resultem em confusão quanto à origem e qualidade de determinada marca e produto,

\footnotetext{
falsificado, ou dele se utiliza para negociar com produto da mesma espécie, embora não adulterado ou falsificado, se o fato não constitui crime mais grave; IX - dá ou promete dinheiro ou outra utilidade a empregado de concorrente, para que o empregado, faltando ao dever do emprego, lhe proporcione vantagem; X - recebe dinheiro ou outra utilidade, ou aceita promessa de paga ou recompensa, para, faltando ao dever de empregado, proporcionar vantagem a concorrente do empregador; XI - divulga, explora ou utiliza-se, sem autorização, de conhecimentos, informações ou dados confidenciais, utilizáveis na indústria, comércio ou prestação de serviços, excluídos aqueles que sejam de conhecimento público ou que sejam evidentes para um técnico no assunto, a que teve acesso mediante relação contratual ou empregatícia, mesmo após o término do contrato; XII - divulga, explora ou utiliza-se, sem autorização, de conhecimentos ou informações a que se refere o inciso anterior, obtidos por meios ilícitos ou a que teve acesso mediante fraude; ou XIII - vende, expõe ou oferece à venda produto, declarando ser objeto de patente depositada, ou concedida, ou de desenho industrial registrado, que não o seja, ou menciona-o, em anúncio ou papel comercial, como depositado ou patenteado, ou registrado, sem o ser; XIV - divulga, explora ou utiliza-se, sem autorização, de resultados de testes ou outros dados não divulgados, cuja elaboração envolva esforço considerável e que tenham sido apresentados a entidades governamentais como condição para aprovar a comercialização de produtos."

${ }^{165}$ A publicitada ilícita resulta no dever de reparação do dano causado. Do ponto de vista do consumidor, o direito à indenização está insculpido no artigo $6^{\circ}$, inciso VI, do CDC. Os direitos de concorrentes à eventual reparação decorrente de propaganda ilícita veiculada por terceiro que lhes cause dano decorrem dos artigos 186 c/c 927 do Código Civil.

${ }^{166} \mathrm{Na}$ mesma linha, explica Dias (2013), que a publicidade enganosa com o objetivo de dificultar o desenvolvimento de empresa concorrente pode ser enquadrada dentro do tipo geral previsto no artigo 36, $\S 3^{\circ}$, inciso IV, da Lei $n^{\circ} .12 .529 / 2011$.
} 
podem, além de configurar atos atentatórios ao direito do consumidor e atos de concorrência desleal, caracterizar um abuso de posição dominante, desde que esteja bem estabelecido o liame entre o ato ilícito, a posição dominante do agente que a perpetra e os efeitos potenciais ou reais sobre o mercado.

Este liame deve ser estabelecido de forma muito clara e objetiva para que não haja um desincentivo generalizado à publicidade ${ }^{167}$ e os agentes econômicos não sejam sujeitos a multas administrativas altíssimas da Lei $n^{\circ}$. 12.529/2011, quando, na realidade, a prática não tem qualquer efeito sobre a concorrência, mas apenas sobre concorrentes.

Há, nesse sentido, uma preocupação de que a legislação concorrencial não se torne uma panaceia para todos os males decorrentes das práticas empresariais, em especial, aqueles tipicamente endereçados por legislação própria. Essa preocupação, por sua vez, não anula o fato de que há atos tipicamente tutelados pelo Direito do Consumidor e pela disciplina da concorrência desleal que realmente podem transbordar a esfera privada dos agentes envolvidos e afetar a estrutura do mercado.

Nesses casos, a autoridade concorrencial deve estar preparada para aplicar regras claras de julgamento que, de um lado, não erijam barreiras demasiadas que impeçam a punição de ilícitos com efeitos concorrenciais, e, de outro, que não sejam permissivas demais a ponto de punir indiscriminadamente aquelas condutas que não ultrapassam os interesses privados dos litigantes.

(ii) Requisitos do ilícito: uma análise de jurisprudência nacional e internacional

Os parâmetros considerados pelas autoridades concorrenciais configuração de um ato enganoso e/ou denigritório como anticompetitivos são bastante variáveis.

\footnotetext{
${ }^{167}$ Em Kaiser v. Ambev, a SG (BRASIL, 2013f) ao tratar de práticas denigritórias, esclareceu que há uma preocupação para que "não existam punições que causem o efeito inverso daquilo que se deseja: ou seja, que os empresários fiquem com medo de anunciar e de rivalizar no mercado, porque poderão ser punidos a depender do modo que a publicidade agressiva de seus produtos for feita, sabendo-se de antemão que a Autoridade Concorrencial deve fomentar a rivalidade entre os agentes de mercado".
} 
A autoridade francesa, ${ }^{168}$ de forma bastante objetiva, exige, afora a prova de posição dominante, evidência de que (i) a publicidade não está baseada em dados objetivos e verificáveis; (ii) a publicidade enganos ou denigritória é capaz de influenciar a estrutura de mercado e (iii) há nexo de causalidade entre a conduta e os efeitos sobre o mercado. ${ }^{169}$

\footnotetext{
${ }^{168}$ A pesquisa de jurisprudência europeia sobre o tema resultou em decisões relevantes sobre práticas denigritórias como violações antitruste apenas na França.

${ }^{169}$ Vide Sanofi-Aventis (FRANÇA, 2013), Groupe Canal Plus et al. (FRANÇA, 2010), Gaz Electricité de Grenoble (GEG) (FRANÇA, 2009)e France Télécom (FRANÇA, 2007).
}

Sanofi-Aventis: Em 2013, a autoridade concorrencial francesa condenou a empresa farmacêutica SanofiAventis por infração à concorrência, por entender que esta teria abusado de sua posição dominante no mercado relativo ao medicamento clopidogrel, comumente utilizado no tratamento da Síndrome Coronária Aguda (SCA). A decisão relata que Sanofi-Aventis, durante o período de setembro de 2009 a maio de 2010, aventou uma estratégia denigritória a medicamentos genéricos junto a profissionais da saúde com a finalidade de limitar a entrada desse tipo de droga, e, assim, manter a posição dominante da empresa, a qual comercializava o medicamento de referência - Plavix, e um genérico de titularidade própria - Clopidogrel HCS ${ }^{\circledR}$ ("auto-genérico"). Mais especificamente, a Sanofi-Aventis teria, por meio de visitas médicas e seminários especializados, insinuado que os medicamentos genéricos não teriam as mesmas propriedades e efeitos terapêuticos que o Plavix ou seu genérico, em razão de ter na sua composição um sal diferente, o que, inclusive, poderia causar riscos à saúde do paciente. Dessa maneira, teria incitado os médicos a prescreverem, para os casos de doenças cardiovasculares graves, apenas o Plavix ou Clopidogrel HCS®, sem substituição pelos genéricos. Da mesma forma, teria estimulado os farmacêuticos a, unilateralmente, substituir o Plavix pelo auto-genérico da Sanofi-Aventis, em detrimento de outros genéricos. As insinuações levantadas pela Sanofi-Aventis, a despeito de sua aparência de cientificidade, não eram corroboradas por qualquer teste ou estudo que tivesse comprovado propriedades terapêuticas díspares ou efeitos adversos dos medicamentos genéricos em comparação com o Plavix ou Clopidogrel HCS $®$. No entanto, tendo em vista características peculiares do mercado como a assimetria de informação e a aversão ao risco dos profissionais da saúde, a estratégia da empresa teria resultado numa menor taxa de substituição desses medicamentos pelos genéricos produzidos por terceiros. Com isso, a concorrência entre o medicamente de referência e o auto-genérico, de um lado, e os genéricos, de outro teria sido gravemente arrefecida, o que resultada em maiores preços finais aos consumidores. Nesse contexto, a autoridade entendeu que o liame entre a posição dominante da Sanofi-Aventis e a prática denigritória estava configurada.

Groupe Canal Plus et al.: Em 2010, a autoridade concorrencial francesa também analisou supostas práticas denigritórias no mercado de TVs pagas na França. A France Télécom havia alegado que o Grupo Canal Plus havia abusado de sua posição dominante ao buscar excluir do mercado de distribuição os canis de televisão paga por meio de prática denigritória sistemática, acompanhada de ameaças e pressões. France Télécom defendeu que as declarações feitas pelo Grupo Canal Plus tinham por objetivo apresentar aquela empresa como objetivamente incapaz de exercer a função de operadora de TV e desacreditá-la frente a possíveis parceiros comerciais e do mercado financeiro. Dessa maneira, as declarações teriam tido um forte impacto, considerando o renome e a posição histórica do Grupo Canal Plus no mercado/ de TV paga. A autoridade francesa concluiu que as afirmações do Grupo Canal Plus eram objetivas e verificáveis. Outras refletiam afirmações gerais do setor que não podem ser consideradas denigritórias, ou, ainda, representavam a expressão de uma rivalidade normal entre empresas do mercado. Com isso, não foi verificada qualquer prática anticoncorrencial derivada de conduta denigritória.

Gaz Electricité de Grenoble (GEG): A autoridade concorrencial francesa condenou, em 2009, a sociedade de economia mista Gaz et Electricité de Grenoble (GEG) por abuso de posição dominante no mercado de fornecimento de energia elétrica a pequenos empresários em 2005. A GEG, que detinha o monopólio no mercado de fornecimento de energia elétrica na região de Grenoble até julho de 2004, veiculou comunicações denigritórias contra o seu único concorrente, Poweo, com o objetivo de impedi-lo de se estabelecer no mercado, que tinha acabado de ser aberto à concorrência (Autorité da La Concurrence, 2009). As comunicações, além de denigritórias, causavam confusão entre as atividades da GEG como distribuidor de energia enquanto prestador de serviços públicos e como fornecedor submetido ao regime da concorrência. Tais atos, segundo a autoridade francesa, tem o condão de excluir um novo concorrente do mercado e, portanto, deve ser condenada do ponto de vista do direito concorrencial. As comunicações 
A jurisprudência norte-americana, por sua vez, não é uniforme. Há tribunais que entendem que publicidade enganosa nunca viola a legislação concorrencial. Outros acreditam que ela tem um efeito "de minimis" na concorrência ${ }^{170}$ e adotam uma série de critérios que a conduta deve preencher para que possa ser considerada uma infração concorrencial. Por fim, há ainda aqueles que sempre

traziam críticas sistemáticas ao comportamento comercial e à qualidade dos serviços do novo concorrente. Além disso, buscavam enaltecer a GEG enquanto operador histórico no mercado. Todavia, a comunicação não deixava claro que sua tradição e renome estavam ligados ao mercado de distribuição e não ao mercado de fornecimento de energia. A autoridade francesa declarou as comunicações denigritórias, pois elas não estavam baseadas em constatações que puderam ser comprovadas. Não havia, na época, elementos que permitissem atribuir qualquer descrédito a Poweo. As declarações, portanto, eram puramente pejorativas e induziam em erro os clientes potenciais do concorrente. Ademais, ao ressaltar suas características enquanto prestadora de serviço público em um mercado distinto do de fornecimento, a GEG buscou obter uma vantagem desta posição para alavancar sua imagem neste mercado, o que não se coaduna com "une concurrence par les mérites". Na visão da autoridade francesa, os efeitos da conduta da GEG puderem ser percebidos claramente no mercado. Esta empresa, em razão de sua antiguidade no mercado de gás e eletricidade e sua forte notoriedade, tinha a confiança do público, que efetivamente foi persuadido pela comunicação da empresa. Com efeito, após as mensagens denigritórias, houve resilições contratuais de clientes com relação a Poweo, queda nas vendas dessa empresa e diminuição no número de contratos celebrados. Diante disso, a autoridade francesa concluiu, em definitivo, pelo abuso de posição dominante da GEG.

France Télécom (FRANÇA, 2007): Em 2007, a sociedade France Télécom foi acusada, dentre outras práticas, de abusar de sua posição dominante por convidar agentes comerciais de sua filial a denegrir a imagem de concorrentes no mercado de fornecimento de acesso à internet. Cabe mencionar que, à época, a France Télécom era um tradicional operador de serviços de telecomunicações na França e a concorrência nesse setor ainda estava em estágio inicial. Nesse contexto, esta empresa beneficiava-se, aos olhos do público, da notoriedade de um antigo monopólio estatal do setor das telecomunicações. Era, ainda, o principal ator mundial de internet de banda larga, especialmente devido ao fato de possuir quase todas as linhas de assinantes e uma vantagem histórica em termos de transmissão de dados capilaridade. A France Télécom adotou uma política de vendas junto a clientes que se interessavam por ofertas de acesso à internet, no qual estimulava os agentes comerciais a fornecerem informações falsas e desprovidas de qualquer objetividade sobre os serviços prestados por concorrentes. As informações eram muito prejudiciais na medida em que diziam respeito a informações essenciais sobre a qualidade técnica do serviço que os consumidores não podiam avaliar a priori. Diante disso, a autoridade francesa entendeu que as informações negativas veiculadas pela France Télécom, referência histórica e pública em matéria de telecomunicações, era particularmente dissuasiva perante o público leigo. Assim, conclui que "France Télécom a abusé de sa position dominante sur le marché de la boucle locale, lui conférant uneplace singulière d'interlocuteur référent,en ayant invité ses agents commerciaux à dénigrer les FAI [fournisseur d'accès à Internet] concurrents de sa filiale Wanadoo par la miseen place d'un contre-argumentaire véhiculé sur une application (Americ) de l'Intranetde l'entreprise. Une telle pratique de dénigrement, dont ni la matérialité, ni la qualification ou l'imputabilité ne sont contestées, constitue un abus de position dominante prohibée tant par l'article L. 420-2 du Code de commerce ainsi que par 1'article 82 du Traite CE” (FRANÇA, 2007, para. 83).

${ }^{170}$ De acordo com Stucke (2010, p. 1087), a presunção segundo a qual a propaganda enganosa tem efeito mínimo sobre a concorrência não faz qualquer sentido lógico e econômico, carecendo, ainda, de evidência empírica que a sustente. Nesse sentido, explica o autor: "If product disparagement is ineffectual, why would any firm, much less a monopolist, engage in it? A rational profit-maximizing monopolist recognizes that deceit has costs, including the costs for the deceptive advertising and promotional campaign and the potential loss of sales, goodwill, and competitive advantage if the deceit is discovered. A monopolist would not falsely disparage a rival's products unless its anticipated gains (maintaining or attaining profits) outweigh its costs. A profit-maximizer would not casually incur advertising costs to falsely disparage a rival's products and expose itself to criminal and civil liability if buyers, as the Treatise claims, dismiss such ads as "nonobjective and highly biased". 
condenam a publicidade enganosa realizada por um agente monopolista (STUCKE, 2010).

Os tribunais norte-americanos que adotam critérios mais rigorosos para condenação da prática denigritória sob a perspectiva antitruste seguem, basicamente, e sem qualquer análise mais profunda, a doutrina dos Professores Areeda, Turner e Hovenkamp.

Para esses autores, a publicidade enganosa somente tem um efeito sobre a concorrência em raríssimas ocasiões. Em razão disso, propuseram um teste com seis condições, que devem ser preenchidas cumulativamente para que haja um ilícito antitruste. Nesse sentido, Areeda e Hovenkamp esclarecem que a publicidade deve ser “(1) clearly false, (2) clearly material, (3) clearly likely to induce reasonable reliance, (4) made to buyers without knowledge of the subject matter, (5) continued for prolonged periods, and (6) not readily susceptible of neutralization or other offset by rivals" (2008, p. 327).

No cartel dos genéricos (BRASIL, 2005a), em que se condenou empresas farmacêuticas fabricantes de medicamentos de referência por tentativa de boicote à entrada dos genéricos do Brasil, dentre as estratégias utilizadas pela empresas envolvidas estaria a campanha publicitária concretizada via Associação Brasileira da Indústria Farmacêutica - ABIFARMA junto à classe médica e à população cujo slogan era "não troque esta receita". A ABIFARMA teria distribuído selinhos e carimbos aos médicos e despendido milhões de reais em informes publicitários.

Da análise dos votos proferidos pelos Conselheiros do CADE não há detalhes sobre a campanha (e.g. se ela teria natureza denigritória ou enganosa). Inclusive, em voto vencido do então Conselheiro Ricardo Villas Bôas Cueva, um dos motivos pelos quais votou pelo arquivamento da investigação foi "a indefinição das linhas de ação propostas pelas representadas. Não ficou claramente demonstrado se as representadas visavam efetivamente esclarecer o público sobre as diferenças, então obscuras, sobre medicamentos similares e genéricos, ou se, ao revés, procuraram dificultar, como inferido pela SDE, a introduçao no mercado destes últimos (...)".

No entanto, a existência de uma campanha via ABIFARMA para desincentivar a troca de remédios na farmácia e a existência de ata de reunião que demonstrava a intenção dos associados de desenvolver "um programa de Qualidade 
contra genéricos para a mídia, visando atingir os consumidores" motivou o Conselho, por maioria, a considerar, nos termos do voto do então Conselheiro Luis Fernando Rigato Vasconcellos, que existiam elementos suficientes para a condenação de todos os laboratórios participantes da reunião pela tentativa de boicote, que o potencial de (a) limitar ou impedir o acesso de novas empresas ao mercado (art. 36, inc. III) e (b) criar dificuldades à constituição, ao funcionamento ou ao desenvolvimento de empresa concorrente (art. 36, inc. IV).

Considerando que um dos principais motivos para a condenação das empresas foi a campanha publicitária da ABIFARMA e suspostos programas midiáticos contra os genéricos, parece razoável supor que uma análise probatória mais detalhada sobre a natureza dessas campanhas (i.e. existência de informações falsas, enganosas, denigritórias) e seus efeitos sobre a entrada de medicamentos genéricos deveria ter sido realizada pelo CADE antes que pudesse chegar a qualquer conclusão.

Em Kaiser vs. Ambev (BRASIL, 2014b), por sua vez, no qual além de brand preemption, o CADE investigava a Ambev por supostamente lançar uma campanha difamatória contra cervejas da Kaiser, os requisitos propostos por Areeda e Hovenkamp chegaram a ser mencionados. Todavia, a autoridade brasileira analisou basicamente o elemento de falsidade da campanha e seus efeitos sobre o mercado, descartando os outros requisitos propostos pelos autores norte-americanos. ${ }^{171}$ Entendese que foi acertada a posição da autoridade brasileira de não seguir à risca as condições estabelecidas por Areeda e Hovenkamp.

Com efeito, não está clara qual a fundamentação por detrás desses seis elementos propostos por esses autores: eles não são explicados por qualquer embasamento fático ou econômico. Dessa maneira, não é possível entender em que medida eles contribuem para a análise antitruste (STUCKE, 2010).

\footnotetext{
171 “(...) no Direito Comparado, não é pacífica a doutrina ou a jurisprudência relacionada à possibilidade de punição antitruste desse tipo de conduta, não havendo, por conseguinte, consenso sobre quais seriam os requisitos mínimos capazes de separar o que seria punível em relação a uma publicidade feita pelo incumbente contra os seus concorrentes. (...) De modo geral, porém, um ponto que parece ser comum a todos os posicionamentos relacionados acima é o de que, para poder configurar uma infração antitruste de product disparagement, é preciso, no mínimo, que a campanha publicitária possua um elemento de falsidade contra o concorrente alvo. (...) Para além disso, e mais importante, não há demonstração de efeitos concorrenciais decorrentes" (BRASIL, 2013, pp. 29-30). Ademais, em seu voto, o Conselheiro Ricardo Ruiz afirmou que "[D]e modo geral (...), um ponto que parece ser comum a todos os posicionamentos (...) é o de que, para poder configurar uma infração antitruste, a depreciação de produtos e concorrentes requer, no mínimo, que a campanha publicitária possua um elemento de falsidade contra o concorrente alvo" (2014, p. 28).
} 
Os três primeiros critérios fazem sentido para caracterizar a enganosidade. Em última instância, a publicidade deve conter informações falsas, esta falsidade deve ser relevante de modo a induzir os consumidores a acreditarem no que está sendo veiculado. No entanto, o requisito de informações claramente falsas pode ser impraticável sobretudo quando se estiver diante de declarações confusórias, que, embora não fundadas em dados falsos, podem distorcer fatos - resultando em falsidade - e induzir o consumidor em erro.

O quarto critério - de que as declarações sejam feitas a consumidores que não tenham conhecimento do assunto - parece descabido. Averiguar se um grupo de consumidores tem ou não conhecimento do assunto parece ser não um critério necessariamente intrínseco da conduta, mas sim um ponto complementar à análise de efeitos da conduta. Afinal, se uma empresa direciona a publicidade a um público alvo não leigo e que não se deixa afetar pela enganosidade, ela não surtirá qualquer efeito seja para concorrentes, seja para a concorrência. ${ }^{172}$

O quinto critério - que exige que as declarações enganosas sejam feitas em períodos prolongados de tempo - é, nas palavras de Stucke (2010), arbitrário. De acordo com o autor, não é possível inferir que uma declaração enganosa, uma vez realizada, porém não repetida, não cause prejuízo e que uma conduta continuada e repetida seja necessariamente prejudicial. A questão fundamental é se a declaração é razoavelmente capaz de contribuir de forma significante para a manutenção ou aumento do poder de mercado do agente investigado. Não importa por quanto tempo ou com qual frequência a publicidade foi veiculada.

Por fim, o sexto critério é bastante discutível. De fato, trazer para a autoridade antitruste o ônus de demonstrar que os concorrentes não eram capazes de neutralizar a publicidade enganosa ou denigritória pode ser excessivo. Essa questão pode ser levantada pelo agente monopolista como um argumento relativo aos efeitos da prática. Nessa linha, tendo o concorrente como pronta e facilmente neutralizar a estratégia nociva do agente com posição dominante, em tese, a conduta não teria potencialidade de gerar efeitos no mercado.

Todavia, um agente monopolista racional sabe que a publicidade enganosa ou denigritório envolve custos. Se um concorrente pudesse efetivamente

\footnotetext{
${ }^{172}$ Nesse sentido, afirma Stucke que "[...] knowing that the buyer has such knowledge, a rational monopolist would not deceive them" (2010, p. 1092).
} 
neutralizar sua campanha com baixo custo e poucos esforços, a teoria econômica neoclássica demonstraria que a prática não geraria benefícios. Ao contrário, o monopolista assumiria riscos consideráveis relacionados à perda de sua reputação e vendas, ao mesmo tempo em que incorreria custos com uma campanha publicitária sem utilidade.

Nessa linha, pode-se dizer, que um agente que assume o risco de uma publicidade ilícita espera ter benefícios, isto é, vantagens sobre os concorrentes. Dessa maneira, mais importante do que qualquer consideração sobre a capacidade dos concorrentes neutralizarem a publicidade difamatória, é necessário verificar se o agente econômico não está criando barreiras à entrada, sinalizando para potenciais entrantes as retaliações a que poderiam estar sujeitos. ${ }^{173}$

Diante disso, pode-se afirmar que o mais importante para a configuração de uma publicidade difamatória como uma infração antitruste é, afora a constatação de poder de mercado do agente que a veicula, verificar o potencial enganoso ou confusório da mensagem publicitária. Para tanto, os parâmetros e experiência adquirida no âmbito do Direito do Consumidor podem ser empregados nessa primeira etapa da análise concorrencial. $^{174}$

Em seguida, é imprescindível verificar se a conduta tem efeitos sobre a concorrência, seguindo os parâmetros estudados no item 4.2.3. Por fim, é necessária a demonstração do liame (nexo de causalidade) entre a publicidade difamatória e o prejuízo à concorrência.

Note-se que, no caso de uma publicidade falsa ou denigritória feita no contexto de um cartel, a necessidade de demonstração dos efeitos da prática sobre o

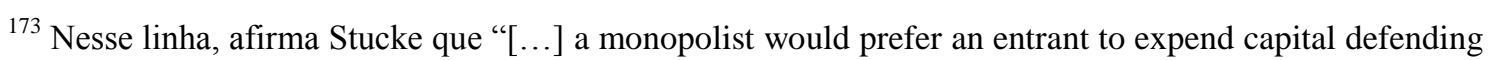
its image rather than in expanding its business, and thereby threaten the monopoly. Advertising can be an effective entry barrier" (2010, p. 1095).

${ }^{174}$ De acordo com o art. 37 do CDC: "É proibida toda publicidade enganosa ou abusiva. § $1^{\circ}$ É enganosa qualquer modalidade de informação ou comunicação de caráter publicitário, inteira ou parcialmente falsa, ou, por qualquer outro modo, mesmo por omissão, capaz de induzir em erro o consumidor a respeito da natureza, características, qualidade, quantidade, propriedades, origem, preço e quaisquer outros dados sobre produtos e serviços. $\S 2^{\circ}$ É abusiva, dentre outras a publicidade discriminatória de qualquer natureza, a que incite à violência, explore o medo ou a superstição, se aproveite da deficiência de julgamento e experiência da criança, desrespeita valores ambientais, ou que seja capaz de induzir o consumidor a se comportar de forma prejudicial ou perigosa à sua saúde ou segurança. § $3^{\circ}$ Para os efeitos deste código, a publicidade é enganosa por omissão quando deixar de informar sobre dado essencial do produto ou serviço." Para um estudo completo sobre os requisitos para aferir a publicidade enganosa ou abusiva sob o ponto de vista do Direito do Consumidor, veja DIAS, 2013, pp. 99-214.
} 
mercado é secundária, já que, a partir do objetivo colusivo do acordo, é possível deduzir prejuízo à concorrência.

\subsubsection{Estratégias de marketing no varejo}

\section{Espaço em prateleira}

É prática comum de grandes redes varejistas cobrar por espaço na prateleira, que representa elemento primordial para a exibição do produto do fornecedor e fator estratégico na promoção comercial da mercadoria, sobretudo quando se exibe o produto em espaços diferenciados.

Goldberg (2006) identifica duas espécies de pagamento usualmente exigidos do fornecedor pelo varejista: (i) o slotting fee, que representa um pagamento antecipado pelo uso do espaço ; e (ii) a pay-to-stay fee, que é um pagamento para manutenção do produto no espaço em que foi alocado.

Os contratos de locação de espaço em prateleira podem gerar preocupações concorrenciais quando envolvam acordos de exclusividade. Nesse caso, o fornecedor pode celebrar um contrato exclusivo com o varejista para impedir a entrada ou o desenvolvimento de concorrentes.

Os contratos de locação de espaço e outros contratos de distribuição que envolvam exclusividade, no entanto, só terão capacidade de produzir efeitos anticompetitivos se forem celebrados por um fornecedor com posição dominante que possa controlar uma parcela suficiente da distribuição por um período suficiente de tempo ${ }^{175}$ de modo que os rivais sejam de fato impedidos de atingir uma escala mínima eficiente. Se um concorrente é obrigado a reduzir escala em virtude de falta de acesso ao sistema de distribuição, ele opera a um custo médio maior, o que tem dois efeitos: (a) em primeiro lugar, o concorrente não é capaz de disciplinar ou exercer pressão sobre aumentos de preços do agente com posição dominante, o que possibilita este último a abusar de seu poder de mercado; (b) em segundo lugar, a médio ou longo prazo, o

\footnotetext{
175 Diversos precedentes nos Estados Unidos estabeleceram uma espécie de isenção antitruste para aqueles contratos exclusivos que tenham curta duração (e.g. menos de um ano) ou que possam ser facilmente rescindidos (WRIGHT, 2006).
} 
concorrente será forçado a sair do mercado, pois não terá meios para operar de forma eficiente (WRIGHT, 2006).

Neste contexto, a celebração de contratos de locação de espaço em prateleiras com cláusula de exclusividade quando sejam firmados por varejistas e fornecedores com posição dominante em dado mercado relevante pode gerar preocupações de ordem concorrencial. Naturalmente, este tipo de contrato não pode ser considerado ilegal per se. É necessário avaliar o mercado do produto objeto do contrato, o poder econômico do agente, as condições de rivalidade do mercado, as barreiras à entrada, o tempo de duração do contrato, suas justificativas e possíveis eficiências. De qualquer modo, sempre que houver contrato de locação de espaço, exclusividade e agente com posição dominante, as luzes do antitruste se ascenderão e uma análise mais apurada do contrato e seus efeitos sobre o mercado deverá ser realizada.

Recentemente, em Vigor v. Kellog e Danone, a Vigor acusou a Danone de comprar "espaço em gôndolas, em supermercados, como prática usual, reservando para si cerca de 50\% das gôndolas disponíveis" (BRASIL, 2013e, p. 4). A SG, todavia, em parecer pelo arquivamento do caso, entendeu que a Representante não teria apresentado provas robustas sobre a ocorrência da prática. Além disso, adotou uma postura um tanto quanto cética quanto ao caráter anticoncorrencial da conduta, afirmando que "a prática de compra de espaço em gôndolas é recente e a jurisprudência internacional sobre o tema é pouca e controversa. (...) ainda que houvesse evidências da prática, a sua legalidade seria questionável, a depender de suas características e contexto" (BRASIL, 2013e, p. 17).

(ii) Gerenciamento de categoria e a figura do capitão de categoria

No campo do merchandising, estratégias são utilizadas no varejo para aumentar o nível de satisfação do consumidor e aumentar as vendas do estabelecimento e do produto do fornecedor, beneficiando assim a todos os elos da cadeia: produtor, varejista e consumidor.

Com o desenvolvimento do varejo, há uma crescente preocupação dos gestores em adotar novos comportamentos para valorizar a aplicação do ciência e da tecnologia nos negócios de modo a aprimorar a coordenação entre produção, 
distribuição, circulação e consumo e, assim, contribuir para o melhor posicionamento competitivo dos varejistas no mercado e sua diferenciação frente a concorrentes. A concorrência por preços passa a não ser o único fator relevante no varejo, sendo crescente a preocupação de criação de valor para o cliente de maneira a aumentar o diferencial do varejista em relaçao a concorrentes (MARQUES; ALCÂNTARA, 2004).

É nesse contexto que se desenvolve a estratégia que se convenciou chamar de "gerenciamento de categoria". Muitas vezes, o consumidor se pergunta por que e como produtos são posicionados de determinada maneira nas prateleiras de uma farmácia ou nas gôndolas de supermercado. A estratégia por detrás pode estar ligada a esse fenômeno.

Por meio dessa prática, os varejistas, com o auxílio de um fornecedor, denominado "capitão de categoria", toma decisões sobre quais marcas um varejista deveria comercializar dentro de uma determinada categoria de produtos, onde elas deveriam ser posicionadas nas prateleiras e, eventualmente, a que preços e, ainda, se deveriam ser objeto de promoções. Com isso, o varejista consegue utilizar o limitado espaço nas prateleiras de forma mais eficiente e lucrativa, isto é, organiza os produtos de forma mais satisfatória à demanda do consumidor, aumentando sua fidelidade ao estabelecimento, por conseguinte, as vendas do estabelecimento (LORDEN, 2011).

O capitão de categoria é selecionado pelo varejista para gerenciar toda a categoria, incluindo a marca de concorrentes (MARQUES; ALCÂNTARA, 2004). Em geral, é escolhido um fornecedor relevante no mercado, cujas responsabilidades no que tange ao gerenciamento da categoria podem variar.

Em geral, o capitão de categoria fornece informações e dá conselhos ao varejista com base em seu vasto conhecimento e expertise sobre as preferências do consumidor em um dado mercado (LORDEN, 2011). Uma vez que a indústria tem informações detalhadas sobre o consumidor de seus produtos, tem know how derivado de pesquisas de mercado e, ainda, recursos analíticos e tecnológicos (e.g. software) que o varejo não possui, o varejo pode beneficiar-se de todo esse amplo conhecimento para melhorar sua gestão (MARQUES; ALCÂNTARA, 2004). Com efeito, para o varejista, o gerenciamento de categoria "pode ser apontada como uma ferramenta que proporciona a fidelização de seus clientes e um diferencial em relação à concorrência" (MARQUES; ALCÂNTARA, 2004, p. 157). 
Em um cenário ideal, portanto, o gerenciamento de categoria melhora a eficiência do estabelecimento, contribui para o aumento de vendas dos fornecedores e aumenta o bem-estar do consumidor. Contudo, dado que o capitão de categoria geralmente representa um fornecedor relevante - muitas vezes, o próprio líder de mercado - que tem naturais interesses egoísticos relacionados à manutenção ou mesmo incremento de sua posição de mercado, há certo ceticismo na ideia de que este mesmo capitão estará totalmente voltado ao aprimoramento das vendas da categoria como um todo, visando inclusive ao aumento das vendas de seus concorrentes. É aqui que as preocupações concorrenciais começam a aparecer.

A prática de gerenciamento de categoria pode gerar efeitos anticoncorrenciais na medida em que o capitão da categoria (i) tenha acesso a informações comercialmente sensíveis de concorrentes (e.g. preços, planos de ação, promoções, etc.), (ii) adote estratégias para prevenir a entrada ou expansão de concorrentes, (iii) facilite ou promova comportamento colusivo entre os fabricantes (EUA, 2001) ou (iv) adote um comportamento lesivo em relação ao concorrente, por exemplo, por meio de práticas difamatórias (ABA, 2010). Pode haver ainda preocupações concorrenciais em situações nas quais o fornecedor e o varejista discutam a estratégia de venda para as marcas do fornecedor e as marcas próprias do varejista que sejam concorrentes (LEARY, 2004). Em resumo, portanto, as preocupações relacionada à prática do gerenciamento de categoria estão ligadas às questões de exclusão de concorrentes e, ainda, de comportamentos colusivos.

As práticas exclusionárias podem surgir quando o capitão de categoria tem acesso a informações confidenciais de concorrentes e as utilizam em benefício próprio (para expandir suas vendas) e/ou prejudicar a estratégia do concorrente. Também poderão estar presentes quando o capitão de categoria faça recomendações ao varejista ou, em última instância, tome decisões que afetem a expansão de concorrentes e resultem em maiores preços e menor variedade de produtos ao consumidor (LEARY, 2004). Por fim, práticas difamatórias do capitão de categoria com relação a produtos de terceiros podem ter o potencial de excluir concorrentes do mercado, o que poderia resultar em preocupações concorrenciais. Com efeito, em Conwood Co. v. United States Tobacco Co. (EUA, 2002), a empresa United States Tobacco Co. (USTC), que detinha $77 \%$ do mercado de tabaco tipo moist snuff, foi condenada por infração concorrencial por, dentre outras práticas, abusar de sua posição como capitão de categoria ao fornecer 
informações enganosas aos varejistas na tentativa induzi-los a acreditar que os produtos da USTC vendiam melhor que o de concorrentes e, assim, desestimular a venda empresas concorrentes.

Comportamentos colusivos, por sua vez, podem ser facilitados por meio da figura do capitão de categoria. Varejistas concorrentes podem utilizar-se das informações de um capitão de categoria que lhes seja comum para coordenar preços, eventos promocionais e ofertas de produtos (LEARY, 2004). Ademais, o capitão de categoria pode facilitar a colusão entre fornecedores que podem combinar entre si quem venderá determinada marca em determinada rede varejista, quais serão as ofertas ou promoções, etc.

A despeito desses potenciais efeitos anticompetitivos, a prática de gerenciamento de categoria não deve ser analisada como um ilícito per se. De acordo com Lorden, when perfomed in accordance with antitrust law (...) the practice leads to the product selection and prices most favorable to consumer and can be used to enhance a consumer's shopping experience" (2011, p. 561). No mesmo sentido, a Comissão Europeia entende que "if practiced legally, category management leads to higher customers satisfaction and greater economic benefits" (EUROPA, 2010).

De acordo com as recomendações da Comissão Europeia, em seu "Commission Notice for Guidelines on Vertical Restraint" (EUROPA, 2010), para analisar os efeitos anticompetitivos da conduta, é necessário avaliar o poder de mercado do fornecedor capitão de categoria, o efeito de fechamento que este fornecedor pode impor aos demais concorrentes, a rivalidade do mercado, a existência de barreiras à entrada e a duração do relacionamento do capitão de categoria com o varejista.

Neste contexto, acordos de gerenciamento de categoria entre varejistas e fornecedores terão maior probabilidade de resultar em efeitos anticompetitivos quando o fornecedor tenha posição dominante e seja capaz de controlar a distribuição por um período relevante de tempo. Além disso, quanto maiores forem as barreiras de acesso a um sistema de distribuição pelos concorrentes, maiores serão as chances de que práticas irregulares do capitão de categoria resultem em efeitos negativos à concorrência. Desse modo, a prática merece especial atenção das autoridades antitruste.

A despeito da relevância da prática sob a ótica do Direito Concorrencial, não se tem conhecimento de que o CADE tenha analisado esse tipo de arranjo em 
inquéritos ou processos administrativos. Outra questão que merece aprofundamento é se esse tipo de acordo entre varejistas e fornecedores é passível de notificação ao CADE como um contrato associativo. A reflexão sobre esta pergunta, todavia, será deixada para uma outra oportunidade.

\section{(iii) Exclusividade de merchandising}

Outra prática utilizada pelas empresas para a incrementar a promoção de suas marcas junto aos consumidores é por meio da celebração de contratos de merchandising com cláusula de exclusividade com os pontos de venda. Nesses casos, embora o estabelecimento possa vender marcas concorrentes, ele somente poderá expor anúncios, cartazes, pôsteres, paineis, etc. relacionados àquelas marcas do fabricante com o qual contratou.

Um caso paradigmático no Brasil relaciona-se à investigação, no mercado de cigarros, da prática de exclusividade nos contratos de merchandising celebrados pela Philip Morris e pela Souza Cruz com pontos de venda (SDE v. Philip Morris e Souza Cruz).

No caso, a SDE (BRASIL, 2011d) reconheceu que esse tipo de prática não era ilegal per se. No entanto, eles poderiam afetar a concorrência caso o ponto de venda fosse a variável chave para a competição. A análise do potencial anticompetitivo deveria, ainda, considerar (a) o potencial de fechamento do mercado resultante da prática; (b) a existência de custos relevantes para a abertura de novos pontos de venda; (c) a extensão temporal dos contratos firmados e (d) a as eficiências derivadas da prática.

Com base na análise desses elementos, a SDE considerou que a prática das empresas representava uma infração à ordem econômica na medida em que prejudicava a entrada e o desenvolvimento de outros fabricantes de cigarro. $\mathrm{O}$ ponto de venda foi considerado um fator relevante para a concorrência no mercado de cigarros e o seus fechamento por contratos exclusivos de merchadising.

As representadas, por sua vez, buscaram ressaltar a natureza sui generis do mercado de cigarros, que, apesar de ser um bem de experimentação, e, portanto, em 
tese, haver maior susceptibilidade do consumidor em experimentar novas marcas sobretudo num contexto de alto nível de publicidade, na prática, havia grande lealdade do consumidor à marca. Desse modo, na visão das Representadas, as estratégias de merchandising no PDV para influenciar na decisão do consumidor surtiriam efeito muito limitado quando comparadas a investimentos em distribuição e logística.

Além disso, para as Representadas, a construção do valor da marca não seria promovida precipuamente via PDV, mas sim pela experimentação contínua e regular do respectivo produto em circunstâncias absolutamente alheias ao espaço publicitário disponível para compra dentro dos estabelecimentos comerciais, quais sejam, sobretudo em eventos sociais e comportamentos de grupo. Na perspectiva das acusadas, o aumento das restrições de publicidade de cigarros pela ANVISA corroboraria a ideia de que a construçao do valor da marca passou a depender cada vez mais da experimentação regular do produto, em detrimento da publicidade através dos canais de revenda. Portanto, para a Philip Morris e a Souza Cruz, as atividades de merchandising investigadas não possuiam nenhum efeito significativo em termos de aumento dos custos dos rivais.

Embora o caso não tenha tido nenhuma decisão ou análise definitiva por parte do CADE, uma vez que as partes celebraram termos de compromisso de cessação de conduta comprometendo-se a não mais praticar exclusividade em contratos de merchandising, ele demonstra a importância de se examinar com cautela as características e a dinâmica do mercado objeto da investigação. No caso em questão, o grau de lealdade à marca pelo consumidor bem como a eficácia das estratégias de merchansing via PDV na captação de novos consumidores e aumento das vendas dos fabricantes eram elementos essenciais para se analisar os efeitos da prática sobre o mercado e sobre os quais houve muito debate ao longo do processo.

(iv) Gueltas e os incentivos econômicos informais a vendedores

Outra prática comercial relacionada a promoção de marcas no varejo, porém, pouco explorada no âmbito do direito antitruste relaciona-se ao pagamento de guelta. A guelta é um "incentivo" financeiro informal feito pela empresa fornecedora ao 
vendedor (também pode ser ao gerente) no varejo para alavancar, direta ou indiretamente, as vendas de determinado produto/marca.

Dessa forma, a guelta pode ser usada tanto para incentivar diretamente a venda de determinado produto, quanto para simplesmente conseguir determinados espaços comerciais na loja com maior visibilidade. De qualquer maneira, como resultado da guelta, o vendedor busca direcionar a demanda do consumidor. Esse direcionamento da demanda é particularmente preocupante do ponto de vista do consumidor porque, no mais das vezes, ele não sabe que está sendo induzido a adquirir uma marca em detrimento de outra não em razão de sua qualidade superior, mas sim em virtude do incentivo financeiro que o vendedor recebe.

Não se trata de um promotor de vendas da marca " $x$ ", que o consumidor tem plena ciência de que será parcial quanto às informações que prestará, mas sim um vendedor, empregado do estabelecimento comercial, de quem se tem expectativa que será neutro quanto às informações fornecidas ao consumidor. Neste esteio, a prática afeta a capacidade de escolha do consumidor, o que poderia resultar em violaçao aos deveres de lealdade e transparência nas relações de consumo previstos nos arts. $4^{\circ}, 6^{\circ}$, IV, 36 e 37 do CDC. Ainda, haverá ilegalidade patente aos dispositivos do CDC caso a prática de guelta envolva atitudes denigritórios dos vendedores com relação a marcas concorrentes do fornecedor responsável pelo pagamento.

Por ser uma prática informal, em geral, o pagamento da guelta representa uma ação tática por excelência e não uma ação estratégica do fornecedor com relação aos varejistas. Geralmente, a comunicação é feita, loja a loja, entre o fornecedor e os supervisores e promotores diretamente, sem qualquer institucionalização. Por essa razão, dificilmente se consegue identificar um padrão nacional ou mesmo regional que caracterize uma ação estratégica única. Não se trata, via de regra, de um programa (de relacionamento, fidelidade, premiação e etc.), portanto, estruturado em que todos os funcionários (gerentes, vendedores e promotores ) estão envolvidos e são incentivados.

Contudo, se a prática for adotada pelo fornecedor dentro de uma perspectiva estratégica e, portanto, institucionalizada, é possível que tenha efeitos concorrenciais. Mais especificamente, a prática pode ensejar limitação de acesso de novas empresas ao mercado, criação de dificuldades ao funcionamento e desenvolvimento de empresa concorrente e impedimento de acesso de concorrentes a canais de distribuição. 
Toda essa discussão se insere no campo das práticas exclusionárias que aumentam os custos de rivais. Na medida em que as vendas dos produtos dos concorrentes podem sofrer prejuízo, uma vez que os vendedores "cooptados" pela guelta de um fornecedor buscarão direcionar a demanda para os produtos do fornecedor que lhe confere o benefício, os concorrentes ou (i) terão de oferecer pagamentos mais altos para os promotores de venda para fazer frente a fornecedor que iniciou a prática ou (ii) o seu acesso a determinado canal de distribuição poderá não ser lucrativo, de maneira que terá de diminuir sua produção e não se beneficiará de economias de escala. Em todas essas hipóteses, o rival opera com custos mais elevados, o que pode prejudicar o seu posicionamento no mercado e, a longo, prazo ensejar a sua saída.

Do ponto de vista antitruste, portanto, o pagamento de guelta não é uma prática ilícita per se. Contudo poderá sê-lo a depender de uma análise concreta de sua mecânica de funcionamento, dos valores envolvidos nos pagamentos, da sua abrangência e duração, mas também dos riscos de fechamento de mercado que dela decorre. Para tanto, é necessário avaliar o poder de mercado do agente que a realiza, as condições do mercado, incluindo sobretudo as condições de acesso à rede de distribuição pelos demais fabricantes e a rivalidade entre os agentes do mercado. Notese, por fim, que o incentivo, por parte dos fornecedores, à práticas denigritórias pelos vendedores do estabelecimento é fator que agrava o cenário no qual os efeitos anticompetitivos da prática são analisados.

No caso H-Buster v. PST Eletrônica, a empresa PST atuante no mercado de alarmes automotivos foi acusada de realizar "campanhas promocionais diretas a funcionários, instaladores e compradores, os quais têm cotas e condições impostas pela Positron, que em alguns casos restringe a possibilidade de entrada de outra marca" (BRASIL, 2012c). Não foi feita alusão direta à existência de pagamento de gueltas. No entanto, a existência de campanhas promocionais a vendedores poderia, em tese, revelar algum pagamento informal para a promoção dos produtos no ponto de venda. O caso, todavia, ainda não foi definitivamente julgado pelo CADE. 


\section{CONCLUSÃO}

O presente trabalho procurou analisar os diferentes tratamentos dispensados à marca no âmbito do controle preventivo e do controle repressivo de condutas. A análise da função social das marcas demonstrou que esta é uma propriedade "que se realiza na concorrência e pela concorrência” (BARBOSA, 2008, p. 241). Nesse sentido, não há dúvidas de que está sujeita aos princípios do Direito Concorrencial. Todavia, a maneira como esses princípios balizam a marca no controle de atos de concentração, de um lado, e no controle repressivo de condutas, de outro, difere.

Conforme ressaltado, há até algum tempo, nas décadas de 80 e 90, o CADE sequer reconhecia sua competência para atuar, no controle de condutas, em casos envolvendo violações de direitos marcários, incluindo os atos de concorrência desleal. Atualmente, embora já se reconheça que as violações ao direito marcário, incluindo atos de concorrência desleal, possam surtir efeitos no campo do Direito Antitruste, há certa nebulosidade quanto aos limites da atuação do órgão da concorrência com relação a certos aspectos da conduta envolvendo matéria marcária e de concorrência desleal. No âmbito do controle de atos de concentração, por sua vez, a intervenção nesses direitos, ao menos a partir da edição da Lei $\mathrm{n}^{\circ}$. 8.884/94, sempre esteve clara. A ordem de suspensão da marca Sorriso no caso Colgate / Kolynos (BRASIL, 1996) é um bom exemplo da intensidade com a qual a autoridade concorrencial pode intervir nos direitos marcários como forma de regulação da atividade dos agentes econômicos, em linha com as prescrições do art. 174 da Constituição Federal.

Como demonstrado, esse poder interventivo amplo no campo do controle das concentrações tem sua razão de ser na aplicação do princípio da precaução no contexto do controle preventivo de condutas. A Constituição Federal atribuiu ao Estado amplos poderes de regulamentação da atividade econômica - desde que não resultasse em planejamento econômico, e, nesse contexto, o CADE ganhou poderes para decidir sobre atos de concentração que tenham a potencialidade de causar disfunção no mercado, podendo, quando necessário, desaprová-los ou impor restrições (nas quais se incluem as restrições aos direitos marcários).

Nesse contexto, embora o princípio da precaução seja tradicionalmente utilizado no contexto das discussões sobre regulação de riscos, sobretudo riscos ambientais e para a saúde, aplica-se também ao Direito Antitruste na medida em que a 
legislação autoriza a autoridade concorrencial a tomar decisões sobre situações em relação às quais não há um domínio seguro de seus efeitos, apontando, ainda, para a adoção de uma postura conservadora e de aversão ao risco.

Nessa linha, a autoridade tem competência para intervir e impor restrições a direitos marcários (ou a outros direitos), mesmo quando não se tenha completo domínio das informações sobre os agentes econômicos, a operação em si, o mercado e os modelos econômicos que analisam os efeitos da operação. Não há na seara do controle preventivo o in dubio pro reo (ou in dubio pró-operação). O Estado está autorizado a e deve fazer um juízo de previsibilidade com base nas informações disponíveis, embora esteja claro para todos a assimetria de informações e o limite cognoscitivo da autoridade concorrencial. Portanto, a restrição a direitos marcários no contexto de atos de concentração está justificada pela aplicação desta variante do princípio da precaução também no Direito Concorrencial.

No campo do controle repressivo de condutas, ao contrário, embora também se trabalhe no campo das potencialidades, ${ }^{176}$ está-se no âmbito do Processo Administrativo Sancionador, onde a autoridade julgadora está adstrita ao princípio da estrita legalidade. Em se tratando de condutas que envolvam direitos de propriedade intelectual, no qual se incluem as marcas, não pode o CADE limitar direitos constitucionalmente protegidos com base em algum critério incerto que, eventualmente, possa indicar que o uso do direito tem o condão de afetar a concorrência. Nesse contexto, rechaçam-se critérios puramente econômicos que, com base em um cálculo impreciso sobre os efeitos líquidos da conduta ou do exercício do direito de PI em determinado sentido, concluam pela sua ilicitude. Propõe-se, assim, um critério jurídico objetivo, por meio do qual a autoridade concorrencial possa distinguir o lícito do ilícito nas condutas envolvendo direitos de PI.

Esse critério jurídico objetivo revela-se ainda mais importante em um cenário no qual estão em jogo duas políticas públicas distintas: a de proteção à concorrência e a de proteção à direitos de propriedade industrial. Sendo essas duas

\footnotetext{
176 Nos termos do art. 36 da Lei no. 12.529/2011, “constituem infração da ordem econômica, independentemente de culpa, os atos sob qualquer forma manifestados, que tenham por objeto ou possam produzir os seguintes efeitos, ainda que não sejam alcançados: I - limitar, falsear ou de qualquer forma prejudicar a livre concorrência ou a livre iniciativa; II - dominar mercado relevante de bens ou serviços; III - aumentar arbitrariamente os lucros; e IV - exercer de forma abusiva posição dominante.”
} 
políticas instrumentais e parciais voltada a um fim maior de política econômica, devem harmonizar-se, e não sobrepor-se uma a outra.

Assim, diferentemente de um critério econômico que busca derivar a abusividade de um direito de PI de um cálculo imperfeito dos custos e benefícios sociais da conduta, propôs-se um critério eminentemente jurídico que garanta maior segurança jurídica aos administrados na aferição da ilicitude da conduta, qual seja, o exame do exercício regular do direito. Tal critério reflete uma excludente de antijuridicidade já presente no ordenamento jurídico e amplamente aplicado no âmbito civil (art. 188, I, CC) e penal (art. 23, III, CP).

O exame do exercício regular do direito no contexto de casos envolvendo o uso de direitos de PI não pressupõe uma análise do custo-benefício do exercício do direito, mas sim uma análise da regularidade do seu exercício à luz de sua função social e dos limites que lhe são impostos pelas regras da legislação pertinente (i.e a LPI). Uma vez que o direito seja exercido regularmente dentro desse contexto, não pode a autoridade concorrencial, a pretexto de uma análise econômica dos efeitos líquidos da conduta, reputar o seu exercício ilícito. Conforme ensina Schuartz (2009, p. 11), "a ideia do direito de defesa da concorrência como instrumento de promoção da eficiência (alocativa e produtiva) não pode ir tão longe a ponto de se fazer da obtenção de ganhos de eficiência uma obrigação jurídica”.

Especificamente com relação às marcas, constatou-se que sua função social está intimamente ligada às regras que lhe permitem proteger os investimentos na reputação empresarial de seu titular, coibir comportamentos oportunistas de terceiros e proteger consumidores contra confusão. Assim, a distintividade da marca perante terceiros, garantida pelas regras da especialidade e das marcas notórias, e a coibição de comportamentos desleais, disciplinada pelas regras de concorrência desleal mostram-se como parâmetros importantes para analisar a regularidade da conduta do agente econômico. Constatada a irregularidade do exercício da marca, o Antitruste pode adentrar para analisar se a conduta tem ou não o condão de afetar a concorrência (efeitos reais ou potenciais).

O estudo da jurisprudência nacional e internacional envolvendo o uso da marca mostrou diversas condutas que foram passíveis de análise pela autoridade concorrencial, quais sejam, atos típicos de concorrência desleal, abusos e fraudes em procedimentos de registro de marca, práticas discriminatórias relacionadas à marca de 
certificação, questões ligadas ao licenciamento e atos de predação via inovação. Especificamente no que tange à predação via inovação, buscou-se demonstrar que, dada a dimensão dinâmico-mutável das marcas, que as coloca constantemente em cheque no processo de manutenção de sua relevância, quando não houver uma patente irregularidade no uso da marca (e.g. afronta direta aos dispositivos da LPI), a probabilidade de que haja decisões sancionatórias por parte da autoridade concorrencial que incorram em erro tipo II (sancionar quando a firma é inocente) é muito grande.

Com relação aos casos recentes julgados pelo CADE envolvendo violações de direitos marcários e atos de concorrência desleal, observou-se certa atitude vacilante da autoridade na análise e interpretação direta de institutos típicos da disciplina marcária e de concorrência desleal. Mais especificamente, a autoridade buscou realizar uma análise tangencial daqueles direitos em razão do receio de adentrar nas esferas ou competências que seriam típicas do Judiciário ou do INPI.

No entanto, conforme se defendeu aqui, entende-se que o CADE tem uma ampla liberdade na interpretação dos direitos de PI quando os analise no contexto de inquéritos ou processos para apuração de infração à ordem econômica. $\mathrm{O}$ direito concorrencial, enquanto ramo autônomo do direito, com princípios e métodos interpretativos próprios, pode analisar institutos e figuras de outros ramos que com ele guardem relação sem ter de ficar adstrito ao pronunciamento de outras instâncias.

Dessa maneira, defendeu-se que a autoridade concorrencial tem competência para analisar diretamente questões marcárias e atos de concorrência desleal como, por exemplo, imitação de trade dress, abusividade de pedido de registro, etc. Ela o fará sob o enfoque concorrencial, à luz de sua finalidade e princípios. Não é necessário sair pela tangente analisando apenas questões de simulação, má-fé, existência de "clara carência das condições de ação", "expedientes objetivamente sem fundamento", "ação manifestadamente improcedente". ${ }^{177}$ Assim como outras instâncias decisórias (e.g. jurisdição penal, jurisdição cível, PROCONs, INPI), que cuidam de outros ramos autônomos do Direito (Penal, Consumidor, Propriedade Industrial), poderão analisar fatos comuns que lhes são trazidos pelas partes e tirar suas conclusões à luz das regras próprias de suas respectivas áreas, a autoridade concorrencial deverá proceder da mesma forma.

\footnotetext{
177 Testes realizados tipicamente em casos de sham litigation, conforme sumarizados pela SG no caso Pró-Genéricos v. Eli Lilly (BRASIL, 2014f).
} 
Por fim, demonstrou-se que ainda há um campo fértil de estudo para o Direito Concorrencial na publicidade e no marketing. Enquanto instrumentos essenciais de promoção e construção de valor das marcas, essas áreas têm relação direta com a concorrência do mercado. Suas ações, como se viu, podem ter implicações substanciais no Direito da Concorrência. 


\section{BIBLIOGRAFIA}

AAKER, D. A. Brand Relevence: Making Competitors Irrelevant. São Francisco: Jossey-Bass, 2011.

ABA. Category Management Antitrust Handbook. [S.1.]: ABA Book Publishing, 2010.

ALEMANHA. Tribunal Constitucional Federal da Alemanha. Schloßberg. 1 BvL 9/75, j. 22 maio 1979.

AREEDA, P. E.; HOVENKAMP, H. Antitrust Law: Analysis of Antitrust Principles and their Application. $3^{\mathrm{a}}$. ed. Nova Iorque: Aspen Publishers, 2008.

ARONS, M. D. S. How brands were born: a brief history of modern marketing. The Atlantic, 3 October 2011. Disponivel em: <http://www.theatlantic.com/business/archive/2011/10/how-brands-were-born-a-briefhistory-of-modern-marketing/246012/> . Acesso em: 16 Novembro 2014.

ASCARELLI, T. Teoria de la concurrencia y de los bienes inmateriales. Barcelona: Bosch, 1970.

ASCENSÃO, J. D. O. As Funções da Marca e os Descritores (Metatags) na Internet. Revista da ABPI, n. 61, 2002.

BAGWELL, K. The Economic Analysis of Advertising. In: ARMSTRONG, M.; PORTER, R. Handbook of Industrial Organization. [S.1.]: Elsevier, v. 3, 2007.

Disponivel em: $<$ https://academiccommons.columbia.edu/download/fedora_content/download/ac:11535 6/CONTENT/econ_0506_01.pdf>. Acesso em: 16 Novembro 2014.

BAIN, J. S. Barriers to New Competition: Their Character and Consequences in Manufacturing Industries. Cambridge: Harvard University Press, 1956.

BAIN, J. S. Industrial Organization. [S.1.]: Wiley, 1959.

BAKER, J. B.; BRESNAHAM, T. F. Economic Evidence in Antitrust: Defining Markets and Measuring Market Power. Stanford Law and Economics Olin Working Paper No. 328, Setembro 2006. Disponivel em: <http://dx.doi.org/10.2139/ssrn.931225>. Acesso em: 11 Novembro 2014.

BARBOSA, D. B. Bases Constitucionais da Propriedade Intelectual. [S.1.]. 2002. Disponível em: http://denisbarbosa.addr.com/bases4.pdf.

BARBOSA, D. B. Nota sobre a questão de monopólio e propriedade em face das marcas. [S.1.]. 2005. Disponível em: http://denisbarbosa.addr.com/monomarcas.pdf. 
BARBOSA, D. B. Proteção das Marcas: Uma Perspectiva Semiológica. Rio de Janeiro: Editora Lumen Juris, 2008.

BARBOSA, D. B.; GRAU-KUNTZ, K.; BARBOSA, A. B. N. A propriedade Intelectual na Construção dos Tribunais. Rio de Janeiro: Editora Lumen Juris, 2009.

BARBOSA, P. M. N. As Marcas de Alto Renome Perante o Princípio da Função Social da Propriedade. Revista da ABPI, n. 110, 2011.

BARCELlOS, M. L. L. Propriedade Industrial \& Constituição. Porto Alegre: Livraria do Advogado, 2007.

BARRIONUEVO, A. Cade: os casos Kolynos e Ambev, dez anos depois. Valor Econômico, 3 Novembro 2011.

BARZEL, Y. Measurement cost and the organization of markets. Journal of Law and Economics, v. XXV, p. 27-48, 1982.

BASSO, M. O Direito Internacional da Propriedade Intelectual. Porto Alegre: Livraria do Advogado, 2000.

BERCOVICI, G. Defesa da Concorrência e Proteção à Propriedade Intelectual Compatibilização entre a Política de Defesa Concorrencial e as Demais Políticas Públicas - Limites e Possibilidades da Política de Defesa da Concorrência sob a Constituição de 1988. Parecer jurídico apresentado ao CADE no caso ANFAPE (Processo Administrativo no. 08012.002673/2007-51), 2013.

BESANKO, D. et al. A Economia da Estratégia. 5ª ed. Porto Alegre: Bookman, 2007.

BORK, R. H. The Antitrust Paradox: A Policy At War with Itself. Nova Iorque: The Free Press, 1978.

BOSTYN, S.; PETIT, N. Patent=Monopoly: A Legal Fiction. SSRN, 2013. Disponível em: Available at SSRN: http://ssrn.com/abstract=2373471.

BOTTINI, P. C. Independência das esferas administrativas e penal é mito (Execução Fiscal de Débitos). Revista ConsultorJurídico, São Paulo, 21 maio 2013.

BOUDREAUX, D. J. Turning Back the Antitrust Clock: Nonprice Predation in Theory and Practice. Cato Review of Business \& Government, p. 45-52, 1990.

BOUTARD-LABARDE, M.-C.; CANIVET, G. Droit français de la concurrence. [S.1.]: LGDJ, 1994.

BRASIL. Conselho Administrativo de Defesa Econômica. Bombril v. Lamisa, Processo Administrativo ${ }^{\circ}$ 56. Cons. Rel. Wanor Pereira de Oliveira, j. 27 abril 1983.

BRASIL. Conselho Administrativo de Defesa Econômica. Santa Branca v. Terra Branca, Voto na Sindicância 37, j. 2 julho 1987a. 
BRASIL. Conselho Administrativo de Defesa Econômica. Vinhos e Bebidas Caldas v. Bebidas Cinzano, Voto na Sindicância 7, j. 5 junho 1987b.

BRASIL. Supremo Tribunal Federal. PGR vs. Governador do Estado do Rio de Janeiro e ALERJ, Rp 1397, j. 11 maio 1988.

BRASIL. Conselho Administraivo de Defesa Econômica, Colgate/Kolynos. Relatora Lúcia Helena Salgado, Brasília, j. 18 setembro 1996a.

BRASIL. Conselho Administraivo de Defesa Econômica, Colgate/Kolynos. Relatora Lúcia Helena Salgado, Brasília, j. 18 setembro 1996b.

BRASIL. Conselho Administrativo de Defesa Econômica. Averiguação Preliminar n ${ }^{\text {. }}$. 08000.024891/95-45, DOU 8 outubro 1997.

BRASIL. Conselho Administrativo de Defesa Econômica. Kaiser, Brahmna, Antarctica (constituição da Ambev), Ato de Concentração nº. 08012.005846/1999-12. Rel. Hebe Teixeira Romano Pereira da Silva, j. 29 março 2000a.

BRASIL. Tribunal Regional Federal da $3^{\mathrm{a}}$ Região. Orlando Cezar e outros v. União Federal. Ap. 90.03.012667-4. Rel. Santoro Facchini, j. 8 agosto 2000 b.

BRASIL. Secretaria de Acompanhamento Econômico. Guia para Análise Econômica de Atos de Concentração, Brasilia, 1 agosto 2001.

BRASIL. Procuradoria Federal Especializada Junto ao CADE. Parecer 120/2002. Marcelo Kallil Grigolli - análise do cumprimento do TCD em Colgate/Kolynos, 19 março 2002.

BRASIL. Conselho Administrativo de Defesa Econômica. Cooperativa dos Jornaleiros da Região de Campinas v. Distribuidora Fernando Chinaglia S/A e outros, Processo Administrativo $n^{\circ}$. 08012.006030/1999-51. Rel. Fernando de Oliveira Marques, j. 30 abril 2003.

BRASIL. Conselho Administrativo de Defesa Econômica. Pepsico/CBB, Ato de Concentração no. 08012.000212/2002-30. Rel. Miguel Barrionuevo., 14 julho 2004a.

BRASIL. Conselho Administrativo de Defesa Econômica. SDE vs. TAM e outras, Processo Administrativo $\mathrm{n}^{\circ}$. 08012.000677/1999-70. Rel. Luis Fernando Rigato Vasconcellos, 15 setembro 2004b.

BRASIL. Conselho Administrativo de Defesa Econômica. SDE v. TECONDI e outros, Processo Administrativo ${ }^{\circ}$. 08012.007443/99-17, Relator para acórdão: Ricardo Villas Bôas Cueva, j. 27 abril 2005.

BRASIL. Conselho Administrativo de Defesa Econômica. Conselho Regional da Farmárcia do DF v. Merck et al (Cartel dos Genéricos), Processo Administrativo nº 08012.009088/1999-48. Rel. Ricardo Villas Bôas Cueva, j. 13 abril 2005a. 
BRASIL. Conselho Administrativo de Defesa Econômica. SDE v. Santos Brasil S/A TECON Terminal de Contêineres e outros, Processo Administrativo $\mathrm{n}^{\circ}$. 08012.007443/1999-17. Rel. Luiz Carlos Thadeu Delorme Prado, j. abril 2005b.

BRASIL. Conselho Administrativo de Defesa Econômica. Industrie de Nora v. Petronor, Ato de Concentração $n^{\circ}$. 08012.007113/2005-21. Rel. Luis Fernando Schuartz, j. 25 outubro 2006.

BRASIL. Secretaria de Direito Econômico. GEAP v. AMB, Processo Administrativo $\mathrm{n}^{\circ}$. 08000.013470/1995-25, Parecer de 12 setembro 2007a.

BRASIL. Superior Tribunal de Justiça, Unilever v. Bio Brilho, REsp. 698.855/RJ. Rel. Min. Nancy Andrighi, j. 25 setembro 2007b.

BRASIL. Conselho Administrativo de Defesa Econômica. Oxigases v. White Martins, Averiguação Preliminar nº. 08000.026056/1996-30. Rel. Luiz Carlos Delorme Prado, 31 janeiro 2007c.

BRASIL. Conselho Administrativo de Defesa Econômica. Atacadão/Korcula, Ato de Concentração nº. 08012.0011040/2007-34. Rel. Luiz Carlos Delorme Prado, j. 4 junho 2008a.

BRASIL. Conselho Administrativo de Defesa Econômica. Laboratório Biosintética Ltda v. Laboratório Sandoz S/A, Processo Administrativo nº 08000.021044/1995-92. Rel. Luiz Carlos Thadeu Delorme Prado, j. 9 abril 2008b.

BRASIL. Conselho Administrativo de Defesa Econômica. NRC / Real Comércio. Ato de Concentração nº 08012.0011040/2007-34. Rel. Luiz Carlos Delorme Prado, j. 4 junho $2008 \mathrm{c}$.

BRASIL. Superior Tribunal de Justiça. Koch Advogados Associados vs. Koch e Koch Advogados e Consultores, REsp 954.272/RS. Rel. Min. Nancy Andrighi, j. 13 nov. 2008d.

BRASIL. Conselho Administrativo de Defesa Econômica, Recofarma/Leão Jr. Relator Carlos Emannuel Ragazzo, 17 junho 2009a.

BRASIL. Superior Tribunal de Justiça. Petronílio José Vilela vs. TJSP, RMS 24.559/PR. Rel. Min. Napoleão Nunes Maia Filho, j. 3 dezembro 2009b.

BRASIL. Superior Tribunal de Justiça. Ricavel vs. Ricave, REsp 401.105/RJ. Rel. Min. Honildo Amaral de Mello Castro (Desembargador convocado do TJ/AP), j. 20 outubro 2009c.

BRASIL. Conselho Administrativo de Defesa Econômica. Log\&Print/Tecnicópias II, Ato de Concentração $n^{\circ}$. 08012.000476/2009-60. Rel. Olavo Zago Chinaglia, j. 11 novembro 2009d. 
BRASIL. Conselho Administrativo de Defesa Econômica. ANFAPE v. Fiat e outros (Autopeças), Averiguação Preliminar no. 08012.002673/2007-51. Rel. Carlos Emmanuel Joppert Ragazzo, j. 15 dezembro 2010.

BRASIL. Conselho Administrativo de Defesa Econômica, ANFAPE vs. Fiat e outros (Autopeças), Averiguação Preliminar no. 08012.002673/2007-51. Relator Carlos Emmanuel Ragazzo, j. 15 dezembro 2010a.

BRASIL. Conselho Administrativo de Defesa Econômica. Merck/Schering-Plough, Ato de Concentração nº. 08012.002252/2009-92. Rel. César Mattos, j. 20 outubro 2010b.

BRASIL. Conselho Administrativo de Defesa Econômica. Nilton Filho v. Alcoa Alumínio S.A. Averiguação Preliminar no. 08012.005727/2006-50. Rel. César Costa Alves de Mattos, j. 28 abril 2010c.

BRASIL. Conselho Administrativo de Defesa Econômica. Shoptour, Processo Administrativo nº 08012.004283/2000-40. Rel. Vinícius Marques de Carvalho, j. 15 dezembro $2010 \mathrm{~d}$.

BRASIL. Conselho Administrativo de Defesa Econômica. Log\&Print/Tecnicopias I, Ato de Concentração nº. 08012.008415/2009-41. Rel. Carlos Emmanuel Ragazzo, j. 1 setembro 2010e.

BRASIL. Conselho Administrativo de Defesa Econômica. TIM/Telefonica, Ato de Concentração $n^{\circ}$. 53500.012487/2007, 28 abril $2010 f$.

BRASIL. Conselho Administrativo de Defesa Econômica. SAP/Spring, Ato de Concentração $\mathrm{n}^{\circ}$ 08012.005056/2010-11. Rel. Fernando de Magalhães Furlan, j. 1 setembro $2010 \mathrm{~g}$.

BRASIL. Conselho Administrativo de Defesa Econômica, Sadia/Perdigão, Ato de Concentração nº. 08012.004423/2009-18. Rel. Carlos Emmanuel Ragazzo, j. 13 julho 2011a.

BRASIL. Superior Tribunal de Justiça, INPI vs. Gang Comércio e Vestuário, REsp 1204488/RS. Rel. Min. Nancy Andrighi, p. j. 22, fevereiro 2011 b.

BRASIL. Tribunal de Justiça do Rio de Janeiro. Francisco Marcone de Oliveira v. MP, Ap. 0127804-02.2007.8.19.0001. Rel. Des. Nascimento Povoas Vaz, j. $1^{\circ}$ março 2011c.

BRASIL. Secretaria de Direito Econômico. SDE v, Philip Morris e Souza Cruz, Processo Administrativo $\mathrm{n}^{\circ}$. 08012.003921/2005-10, 8 junho 2011d.

BRASIL. Conselho Administrativo de Defesa Econômica. Pfizer/Wyeth, Ato de Concentração $n^{\circ}$. 08012.001157/2009-71. Rel. Elvino de Carvalho Mendonça, p. 12 setembro 2012a.

BRASIL. Instituto Nacional da Propriedade Industrial. Diretrizes de Análise de Marcas, 11 dez. $2012 b$. 
BRASIL. Secretaria de Direito Econômico. H-Buster v. PST. Procedimento Administrativo $\mathrm{n}^{\mathrm{o}}$. 08012.005009/2010-60, 10 abril 2012c.

BRASIL. Tribunal Regional Federal da $3^{\mathrm{a}}$ Região. União Federal v. Dacio Puzzi e outros, AI 0049877-74.2006.4.03.0000. Rel. Des. Antonio Cedenho, j. 30 julho 2012d.

BRASIL. Conselho Administrativo de Defesa Econômica. ABTA v. ECAD e outros, Processo Administrativo $\mathrm{n}^{\circ}$. 08012.003745/2010-83. Rel. Elvino de Carvalho Mendonça, j. 20 março 2013a.

BRASIL. Conselho Administrativo de Defesa Econômica. Monsanto, Ato de Concentração no 08012.002870/2012-38; Ato de Concentração nº 08012.006706/201208; Ato de Concentração $\mathrm{n}^{\mathrm{o}}$ 08012.003898/2012-34; Ato de Concentração $\mathrm{n}^{\mathrm{o}}$ 08012.003937/2012-01. Rel. Marcos Paulo Verissimo, j. 18 dezembro 2013b.

BRASIL. Instituto Nacional da Propriedade Industrial. Estatísticas Anuais 2000-2012, 2013c. Disponivel em: <http://www.inpi.gov.br/portal/artigo/estatisticas>. Acesso em: 4 dezembro 2014.

BRASIL. Procuradoria Geral Especializada junto ao CADE. Kaiser v. Ambev, Processo Administrativo $\mathrm{n}^{\mathrm{o}}$. 08012.008554/2008-93, j. 27 agosto 2013d.

BRASIL. Superintendência Geral do CADE. Vigor v. Kellog e Danone. Inquérito Administrativo $n^{\circ}$. 08700.005241/2013-92, 23 dezembro 2013e.

BRASIL. Superintendência-Gera do CADE. Kaiser v. Ambev, Processo Administrativo $\mathrm{n}^{\circ}$. 08012.008554/2008-93, 13 agosto 2013f.

BRASIL. Tribunal de Justiça de São Paulo. MP v. Hilton Massuri Kibe, APL 00173025020118260004. Rel. J. Martins, 17 outubro 2013g.

BRASIL. Superior Tribunal de Justiça. Zeloso v. Transall, REsp 1315621. Rel. Min. Nancy Andrighi, j. 4 junho 2013h.

BRASIL. Conselho Administrativo de Defesa Econômica. JBS/Rodopa, Ato de Concentração $n^{\circ}$. 08700.010688/2013-83. Rel. Márcio de Oliveira Júnior, j. 20 agosto 2014a.

BRASIL. Conselho Administrativo de Defesa Econômica. Kaiser v. Ambev, Processo Administrativo $\mathrm{n}^{\circ}$. 08012.008554/2008-93. Rel. Ricardo Machado Ruiz, j. 20 agosto 2014b.

BRASIL. Conselho Administrativo de Defesa Econômica. McDonald's, Processo Administrativo $\mathrm{n}^{\circ}$. 08012.000751/2008-64. Rel. Olavo Zago Chinaglia, j. 4 junho 2014c.

BRASIL. Conselho Administrativo de Defesa Econômica, SULPETRO, Processo Administrativo nº 08012.010075/2005-94. Rel. Gilvandro Araújo, j. 1 outubro 2014d. 
BRASIL. Superintendência-Geral do CADE. JBS/Rodopa, Ato de Concentração nº 08700.010688/2013-83, 13 maio 2014e.

BRASIL. Superintendência-Geral do CADE.Pró-Genéricos v. Eli Lilly, Processo Administrativo $n^{\circ}$. 08012.011508/2007-91. Despacho $n^{\circ}$. 993, 19 agosto 2014f.

BRASIL. Superior Tribunal de Justiça, Nesvita vs. Activia, REsp 1377911. Min. Luis Felipe Salomão, j. 2 outubro 2014g.

BRASIL. Conselho Administrativo de Defesa Econômica. SDE v. Camargo Correa et al (cartel dos cimentos), Processo Administrativo no . 08012.011142/2006-79, j. 3 junho 2014h.

BRUNA, S. V. O Poder Econômico e a Conceituação do Abuso em seu exercício. São Paulo: Revista dos Tribunais, 2001.

BURST, J.-J. Breveté et Licencié - Leurs rapports juridiques dans le contrat de licence. Paris: Librairies Techniques, 1970.

CAMPOS, F. Nome Comercial. In: Direito Comercial. Rio de Janeiro: Freitas Bastos, 1957. p. 41-51.

CAPUCIO, C.; MELO, R. D. Remédios Concorrenciais e propriedade intelectual. In: OLIVEIRA, A. F. D.; RUIZ, R. M. Remédios Antitruste. São Paulo: Singular, 2011. p. 179-210.

CARVAlHO, N. T. P. Abusos dos direitos de patente - um estudo do direito dos Estados Unidos com referências comparativas ao direito brasileiro. Revista da ABPI, n. 12, p. 44-105, 1994.

CASTALDO, A. R. La imputación objetiva em el delito culposo de resultado. Montevidéu: Editorial B de F, 2008.

CERQUEIRA, L. E. B. O princípio da função social da propriedade e as patentes Passado e futuro. Revista da ABPI, n. 82, 2006.

CHAMBERLIN, E. The Theory of Monopolistic Competition. The Economic Journal, 43, No. 172, 1933. pp. 661-666.

CHAVANnE, A.; BURST, J.-J. Droit de la propriété industrielle. Paris: Dalloz, 2006.

CHILE. Tribunal de Defensa de la Libre Competencia. FNE v. CCU, C 263-13, 2013.

CHURCH, J. R.; WARE, R. Industrial Organization: A Strategic Approach. New York: McGraw-Hil, 2000.

COMPARATO, F. K. O indispensável direito econômico. In: Ensaios e Pareceres de Direito Empresarial. Rio de Janeiro: Forense, 1978. 
COMPARATO, F. K. Função Social da Propriedade dos Bens de Produção. Revista de Direito Mercantil, Industrial, econômico e financeiro, São Paulo, Brasil, v. XXV, n. 63, 1986.

COMPARATO, F. K. A Transferência Empresarial de Tecnologia para Países Subdesenvolvidos: Um Caso Típico de Inadequação dos Meios aos Fins. In:

Direito Empresarial: Estudos e Pareceres. São Paulo: [s.n.], 1995.

COMPARATO, F. K. Estado, Empresa e Função Social. Revista dos Tribunais, v. 732, n. 85, Out 1996.

CONDE, F. M. Teoria Geral do Delito. Porto Alegre: [s.n.], 1988.

COPETTI, M. Afinidade entre Marcas: um questão de Direito. Rio de Janeiro: Lumen Juris, 2010.

CRISTIAN, M. R.; STAMATE, A. Formal Rules Versus an Economic Approach in Dealing with Cartels: The Need for More Coherence in European Competition Law. Romanian Journal of European Affairs, v. 11, n. 4, 2011.

DAVIS, L. How do trademarks affect firms' incentives to innovate? DIME IPR Conference. London: [s.n.]. 2006.

DEL NERO, C. A. S. O Significado Jurídico da Expressão "Função Social da Propriedade". Revista da Faculdade de Direito de São Bernardo do Campo, v. 3, p. 79-97, 1997.

DEMSETZ, H. Barriers to Entry. The American Economic Review, v. 72, p. 47-57, 1982.

DIAS, L. A. L. D. M. Publicidade e Direito. $2^{\mathrm{a}}$. ed. [S.1.]: RT, 2013.

EDAP. Um passo atrás, Dezembro 2014. Disponivel em: <http://edap.com.br/informes/um-passo-atras/>. Acesso em: 12 dezembro 2014.

ENTERRÍA, E. G. D.; FERNANDEZ, T.-R. Curso de derecho administrativo. $10^{\mathrm{a}}$. ed. Madri: Civitas, v. II, 2000.

EUA. Supreme Court. Ethyl Gasoline Corp. v. United States, 309 U.S. 436 , 1940.

EUA. Supreme Court. Mercoid Corp. v. Mid-Continent Investment Co., 320 U.S. 661 , 1944.

EUA. Supreme Court. Brown Shoe Co., Inc. v. United States, 370 U.S. 294, 1962.

EUA. Supreme Court. Walker Process v. Food Machinery, 382 U.S. 172, 1965.

EUA. Federal Trade Commission, Borden, Inc. (ReaLemon). Decision No. 8978 , 3 Trade Reg. Rep. (CCH) , j. 19 agosto 1976. 
EUA. Federal Trade Commission, Borden, Inc. (ReaLemon). Decision No. 8978 (modificada), Trade Reg. Rep. (CCH), 27 novembro 1978.

EUA. United States Court of Appeals, Second Circuit. SCM Corp. vs. Xerox Corp., 645 F.2d 1195, 1981.

EUA. Federal Trade Commission, Kellogg Company, et al.(Cereals). 99 F.T.C. 8, 1982a.

EUA. United States Court of Appeals, Borden Inc v. Federal Trade Commission. 674 F. 2d 498, 1982 b.

EUA. ReaLemon Settlement. [1979-1983 Transfer Binder] Trade Reg. Rep. (CCH) II 21,995, 14 março 1983.

EUA. Federal Trade Commission, General Foods Corp. 103 FTC 204, 1984a.

EUA. United States Court of Appeals. Handgards v. Ethicon, 743 F.2d 1282, 1984 b.

EUA. United States Court of Appeals. Scandia Down Corporation v. Euroquilt Inc. 772 F. 2d 1423, 1985.

EUA. United States Court of Appeals for the Federal Circuit. Mallinckrodt, Inc. v. Medipart, Inc., 976 F.2d 700, 1992.

EUA. Supreme Court, Qualitex Co. v. Jacobson Products Co. 514 U.S.159, 1995.

EUA. United States Court of Appeals, Ninth Circuit. Image Technical Services Inc v. Eastman Kodak Co, 125 F. 3d 1195, 1997.

EUA. U.S. Court of Appeals for the Federal Circuit. Nobelpharma AB v Implant Innovations, 141 F.3d 1059, 1998.

EUA. Federal Trade Commission. Report on the Federal Trade Report Commission Workshop on Slotting Allowances and Other Marketing Practices in the Grocery Industry, 2001.

EUA. Corte de Apelação do Sexto Circuito. Conwood Co. v. United States Tobacco Co., 290 F.3d 768, 2002.

EUA. U.S. District Court for the Central District of California. Major League Baseball Properties, Inc. v. Salvino, Inc., 2008a.

EUA. United States Court of Appeals for the District of Columbia Circuit. Federal Trade Commission v. Whole Foods Market, Inc., No. 07-5276, $2008 \mathrm{~b}$.

EUA. U.S. Department of Justice and the Department of Justice. Horizontal Merger Guidelines, 2010.

EUROPA. European Court of Justice. AKZO v Commission, C-62/86, j. 3 julho 1991. 
EUROPA. European Court of Justice. Radio Telefis Eireann (RTE) and Independent Television Publications Ltd (ITP) vs. Commission, Joined cases C-241/91 P and C242/91 P, j. 6 abril 1995.

EUROPA. European Commission. Kimberly-Clark-Scott. Case No IV/M.623, j. 16 janeiro 1996.

EUROPA. Court of First Instance (Third Chamber). Irish Sugar v. Commission, Case T-228/97, j. 7 outubro 1999.

EUROPA. Court of First Instance (Fifth Chamber). Van den Bergh Foods v Commission, T-65/98, j. 23 outubro 2003a.

EUROPA. Court of First Instance (Third Chamber). Michelin v. Commission, Case T203/01, 30 setembro 2003b.

EUROPA. European Commission. Microsoft, Decision No. COMP/C-3/37.792/EEC, 2004a.

EUROPA. European Court of Justice. IMS Health GmbH \& Co. OHG vs. NDC Health GmbH \& Co. KG., C-418/01, j. 29 abril 2004b.

EUROPA. European Commission. Merger remedies study. [S.1.]. 2005. Disponível em: http://ec.europa.eu/competition/mergers/legislation/remedies_study.pdf.

EUROPA. Court of First Instance. Microsoft v Commission, T-201/04, j. 17 setembro 2007.

EUROPA. European Court of Justice. Hoffmann-La Roche vs. Commission, Case 85/76, j. 13 fevereiro 2009a.

EUROPA. European Court of Justice (Grand Chamber). Der Grüne Punkt - Duales System Deutschland v Commission, C-385/07 P, j. 16 julho 2009b.

EUROPA. European Commission. Commission Notice for Guidelines on Vertical Restraint, 2010.

EUROPA. European Court of Justice (First Chamber). AstraZeneca v Commission, C457/10 P, j. 6 dezembro 2012a.

EUROPA. General Court (Seventh Chamber). Protégé International Ltd. vs. Commission. Case T-119/09, j. 13 setembro 2012b.

EVANS, D. S. Lightening Up Market Definition. In: ELHAUGE, E. Research Handbook on the Economics of Antitrust Law. Nova Iorque: Edward Elgar, 2010. Disponivel em: <http://ssrn.com/abstract=1599270>.

FAGUNDES, J.; PONDÉ, J. L. Barreiras à Entrada e Defesa da Concorrência: Notas Introdutórias. Universidade Cândido Mendes. Rio de Janeiro. 1998. 
FARINA, E. M. M. Q.; AZEVEDO, P. F. AMBEV: a fusão e seus efeitos no mercado de cervejas. In: MATTOS, C. A Revolução do Antitruste no Brasil. São Paulo: Singular, v. 1, 2003. p. 131-157.

FARINA, E. M. M. Q.; TITO, F.; ARASHITO, T. How Far have We Come and Where Are We going: The evolution of Merger Review in Brazil. Antitrust in the Americas Conference. Rio de Janeiro: [s.n.]. 2011.

FERRARI, E. R.; GAMEIRO, J. A. P. D. S. O cartel de empresas e seus aspectos criminais. Revista Literária, n. 53, 2004.

FERRAZ JR, T. S. Introdução ao estudo de direito: técnica, decisão, dominação. $4^{\mathrm{a}}$. ed. São Paulo: Atlas, 2003.

FERRAZ JR., T. S. A economia e o controle do Estado. O Estado de São Paulo, 04 Junho 1989.

FERRAZ JR., T. S. Da abusividade do poder econômico. Revista de Direito Econômico - Conselho Administrativo de Defesa Econômica - CADE, n. 21, p. 2330, 1995.

FIGUEIREDO, L. V. Curso de direito administrativo. $8^{\text {a }}$. ed. São Paulo: Malheiros, 2006.

FORGIONI, P. A. Breves notas sobre a posição dominante e seu abuso. Revista de Direito Mercantil, Industrial, Econômico e Financeiro, nova série, v. 36, n. 107, p. 45-69, 1997.

FORGIONI, P. A. Importações Paralelas no Brasil: A Propriedade Industrial nos Quadrantes dos Princípios Constitucionais. Revista de Direito Mercantil, Industrial, Econômico e Financeiro, v. XLVII, n. 149/150, p. 187-200, 2008.

FORGIONI, P. A. Princípios constitucionais econômicos e princípios constitucionais sociais: A formatação jurídica do mercado brasileiro. Revista do Advogado, n. 117, p. 165-176, 2012.

FORGIONI, P. A. Os Fundamentos do Antitruste. $7^{\text {a }}$. ed. São Paulo: Revista dos Tribunais, 2014.

FORRESTER, I. S. Article 82: Remedies in Search of Theories? Fordham International Law Journal, v. 28, n. 4, p. 919-951, 2004.

FRANÇA. Autorité de la Concurrence.France Telécom. Décision n 07-D-33, j. 15 outubro 2007.

FRANÇA. Autorité de la Concurrence. Gaz et Electricité de Grenoble (GEG), Décision $\mathrm{n}^{\circ}$ 09-D-14 , j. 25 março 2009. 
FRANÇA. Autorité de La Concurrence. Groupe Canal Plus et at. Décision n 10-D-32, j. 16 novembro 2010.

FRANÇA. Autorité de la Concurrence. Sanofi-Aventis, Décision 13-D-11, j. 14 maio 2013.

GERADIN, D.; GIRGENSON, I. The Counterfactual Method in EU Competition Law: The Cornerstone of the Effects-Based Approach. Working papers series, 11 Dezembro 2011. Disponivel em: <http://ssrn.com/abstract=1970917>. Acesso em: 22 Novembro 2014.

GOLDBERG, D. Poder de Compra e Política Antitruste. São Paulo: Singular, 2006.

GRAU-KUNTZ, K. O desenho industrial como instrumento de controle econômico do mercado secundário de peças de reposição de automóveis: uma análise crítica a recente decisão da Secretaria de Direito Econômico (SDE). Revista de Direito Mercantil, Industrial, Econômico e Financeiro, São Paulo, n. 145, p. 148-184, 2007.

GRAUS, E. A Ordem Econômica na Constituição de 1988 (Interpretação e Crítica). $3^{\text {a }}$. ed. São Paulo: Malheiros, 1997.

HOVEnKAMP, H. Federal Antitrust Policy: The Law of Competition and Its Practice. $3^{\mathrm{a}}$. ed. [S.1.]: Thomson West, 2005.

HOVENKAMP, H. The Walker Process Doctrine: Infringement Lawsuits as Atitrust Violations. U Iowa Legal Studies Research Paper No. 08-36, 2008. Disponivel em: <http://ssrn.com/abstract=1259877>. Acesso em: 16 Novembro 2014.

HOVENKAMP, H. The Harvard and Chicago Schools and the Dominant Firm. U Iowa Legal Studies Research Paper No. 07-19, 21 junho 2010.

HOVEnKAMP, H. Federal Antitrust Policy: The Law of Competition and its Practice. [S.1.]: Hornbook series, West, 2011.

INSTITUTO DE AÇÃO TECNOLÓGICA E DESENVOLVIMENTO INOVADOR. Guerra de cremes dentais eleva vendas. Valor, 11 Janeiro 2012.

INTERNATIONAL COMPETITION NETWORK (ICN). ICN Merger Working Group: Analytical Framework Subgroup: Merger Remedies Review Project. Report for the 4th ICN Annual Conference. Bonn: [s.n.]. 2005.

KITCH, E. W.; PERLMAN, H. S. Intellectual Property and Unfair Competition. $5^{\text {a }}$. ed. [S.1.]: University Casebook Series, 1998.

KLEIN, B.; LEFFLER, K. B. The Role of Market Forces in Assuring Contractual Performance. Journal of Political Economy, v. 89, n. 4, p. 615-641, 1981.

KUPFER, D.; HASENCLEVER, L. Economia industrial: fundamentos teóricos e práticas no Brasil. Rio de Janeiro: Ed. Campus, 2002. 
LAFRANCE, M. Understanding trademark law. [S.1.]: LexisNexis, 1958.

LANDES, W. M.; POSNER, R. A. Trademark Law: An Economic Perspective. Journal of Law and Economics, v. 30, n. 2, p. 265-309, 1987.

LANDES, W. M.; POSNER, R. A. The Economics of Trademark Law. Trademark Reporter, v. 78, 1988.

LEARY, T. B. A Second Look at Category Management. The American Antitrust Institute's Roundtable Discussion on Antitrust and Category Captains, 2004.

LEMLEY, M. A.; MCKENNA, M. P. Is Pepsi Really a Substitute for Coke? Market Definition in Antitrust and IP. Georgetown Law Journal, v. 100, p. 2055, 2012. Disponivel em: <http://ssrn.com/abstract=2038039>.

LEVITT, T. A imaginação de marketing. 2a . ed. São Paulo: Atlas, 1990.

LILLA, P. E. Propriedade Intelectual e Direito da Concorrência: Uma Abordagem sob a Perspectiva do Acordo TRIPS. São Paulo: Quartier Latin, 2014.

LORDEN, B. J. Category Management: The Antitrust Implications in the United States and Europe. Loyola Consumer Law Review, v. 23, p. 541-564, 2011.

MAISEL, L. C. Submarkets in Merger and Monopolization Cases. Georgetown Law Journal, n. 39, 1983.

MARQUARDT, P. D.; LEDDY, M. The essential facilities doctrine and intellectual property rights: a response to Pitofsky, Patterson and Hooks. Antitrust Law Journal, v. 70, n. 3, p. 847-873, 2003.

MARQUES, C. L. Contratos no Código de Defesa do Consumidor. $3^{\text {a }}$. ed. São Paulo: Revista dos Tribunais, 1999.

MARQUES, É. F.; ALCÂNTARA, R. L. C. O uso da ferramenta gerenciamento por categoria na gestão da cadeia de suprimentos: um estudo multicaso. Gestão\&Produção, v. 11, n. 2, p. 153-164, 2004.

MATHÉLY, P. Le Droit Français des Brevets d'Invention. Journal des Notaires et des Avocates, 1976.

MATTOS, C. Remédios em atos de concentração: a experiência internacional e o Brasil. In: OLIVEIRA, A. F. D.; RUIZ, R. M. Remédios Antitruste. São Paulo: Editora Singular, 2011.

MCCLURE, D. M. Trademarks and Competition: The Recent History. Law and Contemporary Problems, v. 59, n. 2, p. 13-44, 1996. Disponivel em: $<$ http://scholarship.law.duke.edu/cgi/viewcontent.cgi?article=4321\&context=lcp $>$. 
MILLOT, V. Trademarks as an Indicator of Product and Marketing Innovations. OECD Science, Technology and Industry Working Papers. [S.1.]: OECD Publishing. 2009.

MIRAGEM, B. Curso de Direito do Consumidor. 5a . ed. São Paulo: Revista dos Tribunais, 2014.

MORAES, M. Z. D. Presunção da Inocência no Processo Penal Brasileiro: análise de sua estrutura normativa para a elaboração legislativa e para a decisão judicial. Rio de Janeiro: Lumen Juris, 2009.

MUELLER, C. E. Sources of Monopoly Power: A Phenomenon Called "Product Differentiation". The American University Law Review, v. 18, n. 1, 1968. Disponivel em: 〈http://www.wcl.american.edu/journal/lawrev/18/mueller.pdf〉.

NEWMAN, J. S. Deception as an Antitrust Violation. Harvard Law Review, v. 125, p. $1235,2012$.

NORBERTO, E. Estratégias corporativas de marcas e estratégias sociais de diferenciação: uma análise a partir do automóvel. Tempo Social, revista de sociologia da USP, v. 16, n. 2, p. 203-223, 2004.

NUNES, A. J. A. et al. A incostitucionalidade das patentes "pipeline" brasileiras. Revista Eletrônica do IBPI - Patentes Pipeline - Edição Especial, p. 4-73, 2009. Disponível em: http://ibpibrasil.org/ojs/index.php/Revel/article/download/19/19.

NUSDEO, F. Curso de Economia: Introdução do Direito Econômico. 8a . ed. São Paulo: Revista dos Tribunais, 2014.

OCDE. Lei e Política de Concorrência no Brasil - Uma Revisão pelos Pares. [S.1.]. 2010.

OCDE/INNO-TEC. Workshop on Trademarks and Trademark Data. Summary Record. [S.1.]. 2009.

OCDE/INNO-TEC. Workshop on Trademarks and Trademark Data. Summary Record. [S.1.]. 2009.

OECD. Policy Roundtables - Barriers to Entry. [S.1.]. 2005.

OLAVO, C. Propriedade Industrial - Sinais Distintivos do Comércio, Concorrência Desleal. 2a ${ }^{a}$ ed. Coimbra: Almedina, v. 1, 2005.

OLIVEIRA, A. F. D. Remédios Antitruste e o ordenamento jurídico brasileiro: primeiras reflexões. In: OLIVEIRA, A. F. D.; RUIZ, R. M. Remédios Antitruste. São Paulo: Editora Singular, 2011.

ORRICK HERRINGTON \& SUTCLIFFE LLP. EU judge moots effects-based approach for cartel fines. Lexology, 2012 março 2012. Disponível em: 
http://www.lexology.com/library/detail.aspx?g=29b12624-f332-4599-91a2-

0d41d338e123.

PALlADINO, V. N. Compulsory Licensing of a Trademark. Buff. L. Rev., v. 26, p. 112-114, 1977.

PEROTTO, E. R. Conceituando a marca pela enunciação: Uma proposta do campo da comunicação. [S.1.]. 2007.

PFEIFFER, R. A. C. Defesa da concorrência e bem-estar do consumidor. [S.l.]. 2010.

PINDYCK, R. S.; RUBINFELD, D. L. Microeconomia. 7a. ed. [S.1.]: Editora Prentice Hall - Br, 2010.

PITOFSKY, R. New Definitions of Relevant Market and the Assault on Antitrust. Columbia Law Review, v. 90, n. 7, p. 1805-1864, 1990. Disponivel em: <http://www.jstor.org/stable/1122768>.

POSNER, R. A. The Chicago School of Antitrust Analysis. University of Pennsylvania Law Review, n. 127, 1979.

POSSAS, M. L.; MELLO, M. T. L. Regulação da Concorrência e Propriedade Intelectual: conflitos e convergências. Seminário Internacional PPED "Promovendo Respostas Estratégicas à Globalização”. Rio de Janeiro: [s.n.]. 2009.

PRADO, L. C. D. Política de concorrência e desenvolvimento: reflexões sobre a defesa da concorrência. Cadernos do Desenvolvimento, Rio de Janeiro, 6, n. 9, julhodezembro 2011. 321-344.

PROENÇA, J. M. M. Os Termos de Compromisso de Desempenho enquanto Solução Imposta pelo CADE para Aprovação de Operações Restritivas à Concorrência. In: GILBERTO, A. M. C. C. F.; VILELA, J. G. Concentração de Empresas no Direito Antitruste Brasileiro: Teoria e Prática dos Atos de Concentração. São Paulo: Editora Singular, 2011. p. 263-290.

RAGAZZO, C. E. J. Notas Introdutórias sobre o Princípio da Livre Concorrência. Sciencia Juris, v. 10, p. 83-96, 2006.

RAGAZZO, C. E. J. Preço abusivo, eficácia jurídica e análise econômica: afinal, onde está a cabeça de bacalhau? Revista IBRAC, v. 19, p. 21-43, 2011.

REALE, M. Cartel e Quadrilha ou Bando: Bis in idem. Revista de Ciências Penais, São Paulo, n. 5, 2006.

RIBEIRO, E. S. A.; ROLIM, M. J. C. P. A Propriedade Intelectual e a Defesa da Concorrência. In: TIMM, L. B.; BRAGA, R. B. Propriedade Intelectual. Belo Horizonte: [s.n.], 2011. p. 1-16. 
ROSENBERG, B. Considerações sobre Direito da Concorrência e os Direitos de Propriedade Intelectual. In: ZANOTTA, P.; BRANCHER, P. Desafios Atuais do Direito da Concorrência. São Paulo: Singular, 2008.

SALGADO, L. H. O Caso Kolynos-Colgate e a Introdução da Economia Antitruste na Experiência Brasileira. In: MATTOS, C. A Revolução Antitruste no Brasil: A Economia Aplicada a Casos Concretos. São Paulo: Singular, v. 2, 2006.

SALOMÃO FILHO, C. Direito Industrial, Direito Concorrencial e Interesse Público. Revista CEJ, n. 25, 2006.

SALOMÃO FILHO, C. Direito Concorrencial - as condutas. São Paulo: Malheiros, 2007.

SALOMÃO FILHO, C. Direito Concorrencial - as estruturas. São Paulo: Malheiros, 2007.

SANTOS, V. F. D. et al. Análise do preço do milho nos mercados externo e interno. Revista de Política Agrícola, p. 76-84, 2007.

SARLET, I. W.; FENSTERSEIFER, T. Princípios do Direito Ambiental. São Paulo: Saraiva, 2014.

SCHEFFMAN, D. T.; HIGGINS, R. S. Twenty years of Raising Rivals' Costs:History, Assessment and Future. George Mason Law Review, v. 12:2, p. 371-387, 2003.

SCHERER, F. M. The Posnerian Harvest: Separating Wheat From Chaff. The Yale Law Journal, v. 86, n. 5, p. 974-1002, 1977.

SCHIEBER, B. Abusos do Poder Econômico: direito e experiência antitruste no Brasil e nos EUA. São Paulo: Revista dos Tribunais, 1966.

SCHMALENSEE, R. Entry Deterrence in the Ready-to-Eat Breakfast Cereal Industry. The Bell Journal of Economics, v. 9, No. 2 , p. 305-327, 1978.

SCHUARTZ, L. F. Quando o bom é o melhor amigo do ótimo: A Autonomia do Direito perante a Economia e a Política da Concorrência. Revista de Direito Administrativo, Belo Horizonte, maio/ago 2007.

SCHUARTZ, L. F. Parecer no âmbito do caso das garrafas (Processo Administrativo ${ }^{\circ}$. 08012.002474/2008-24), 30 junho 2008.

SCHUARTZ, L. F. Inovações e defesa da concorrência: em busca de uma política que minimize os custos de decisões equivocadas. In: TIMM, L. B.; PARANAGUÁ, P. Propriedade intelectual, antitruste e desenvolvimento: o caso da transferência de tecnologia e do software. Rio de Janeiro: FGV, 2009. p. 35-60.

SEAE. Guia para a Análise Econômica de Atos de Concentração Horizontal, 2001. Disponivel

em: 
$<$ http://www.seae.fazenda.gov.br/central_documentos/notas_imprensa/2000-1/guiapara-analise-de-atos-de-concentracao-economica-horizontal-2000>.

SEMPRINI, A. A marca pós-moderna - Poder e Fragilidade da marca na sociedade contemporânea. $2^{\mathrm{a}}$. ed. São Paulo: Estação das Letras, 2010.

SERRALVO, F. A. Gestão de Marcas e Produtos. [S.1.]: Editora IESDE, 2009.

SILVA, J. A. Curso de Direito Constitucional Positivo. 19ª ed. São Paulo: Malheiros, 2001.

SILVEIRA, N. Propriedade Intelectual. 4a . ed. São Paulo: Manole, 2011.

SOARES, J. C. T. Código de Propriedade Industrial. São Paulo: Resenha Tributária, 1974.

SOARES, J. C. T. Tratado da Propriedade Industrial: Marcas e Congêneres. São Paulo: Editora Jurídica Brasileira, v. 1, 2003.

STIGLER, G. J. The Economics of Information. The Journal of Political Economy, p. 213-225, 1961.

STUCKE, M. E. How Do (and Should) Competition Authorities Treat a Dominant Firm's Deception? Southern Methodist University Law Review, v. 63, p. 1069, 2010.

SUTTON, J. Sunk Costs and Market Structure - Price Competition, Advertising, and the Evolution of Concentration. London: MIT Press, 1996.

TEPEDINO, G.; BARBOSA, H. H.; MORAES, M. C. B. D. Código Civil Intepretato - conforme a Constituição da República. 2a . ed. Rio de Janeiro : Renovar, 2011.

TIMM, L. B. Contrato internacional de transferência de tecnologia no Brasil: intersecção da propriedade intelectual com direito antitruste. In: TIMM, L. B.; PARANAGUÁ, P. Propriedade Intelectual, antitruste e desenvolvimento: O caso da transferência de tecnologia e do software. Rio de Janeiro: FGC, 2009. p. 61-120.

ULLRICH, H. Expansionist Intellectual Property Protection and Reductionist Competition Rules: A TRIPS Perspective. Journal of International Economic Law, 7, 2004.

VERÍSSIMO, M. P. Parâmetros para Definição de Restrições em Atos de Concentração. $17^{\circ}$. Seminário Internacional de Defesa da Concorrência. Guarujá: [s.n.]. 2011.

WRIGHT, J. D. Antitrust Analysis of Category Management: Conwood v. United States Tobacco Co.. Supreme Court Economic Review, 2006.

ZAITZ, D.; ARRUDA, G. F. A função social da propriedade intelectual - patentes e know how. Revista da ABPI, n. 96, 2008. 


\section{LISTA DE JURISPRUDÊNCIA}

ABTA v. ECAD e outros.

AKZO v. Commission

Ambev

73, 103, 105, 119

AstraZeneca v Commission

Atacadão/Korcula

Autopeças 55,145

Bombril v. Lamisa

Brown Shoe $88,91,96$

Cartel dos cimentos 162

Cereals 35,170

Colgate/Kolynos $17,20,73,96,103$

Constituição da Ambev $73,103,119$

Conwood Co. v. United States Tobacco Co. 188

Cooperativa dos Jornaleiros da Região de Campinas v. Distribuidora Fernando Chinaglia S/A e outros 131

DSD v. Commission... 165

Ethyl Gasoline Corp. v. United States. 144

France Télécom 179

Francisco Marcone de Oliveira vs. MP ...................................................................... 133

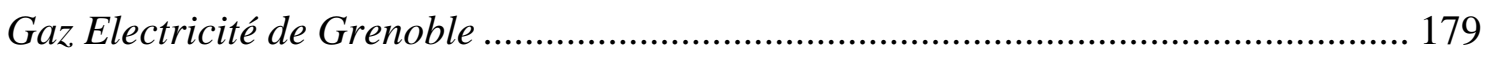

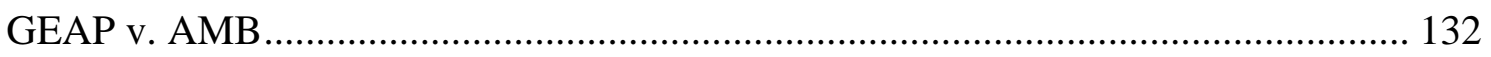

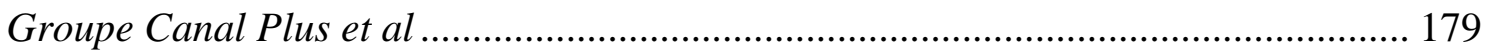

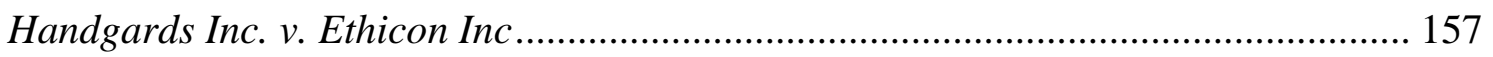

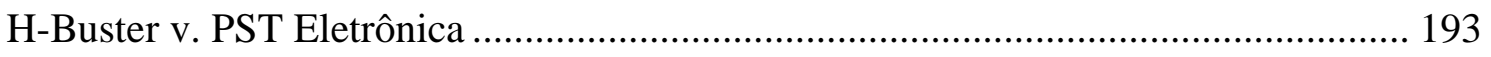

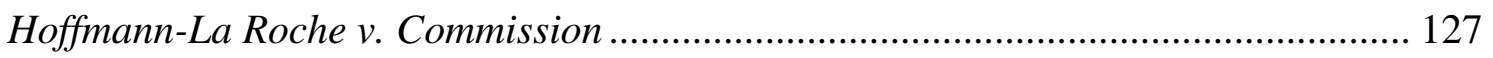

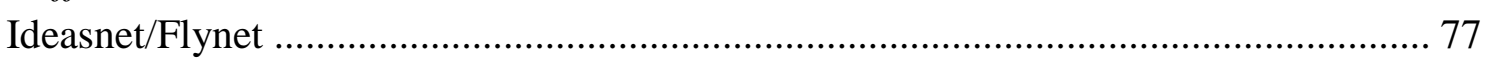

Image Technical Services, Inc. v. Eastman Kodak Co ............................................... 165

IMS Health GmbH \& Co. OHG v. NDC Health GmbH \& Co. KG............................ 141

In Re Independent Service Organizations Antitrust Litigation v. Xerox Corporation 165

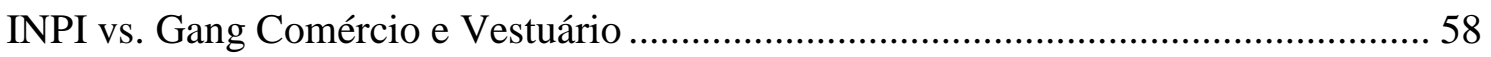

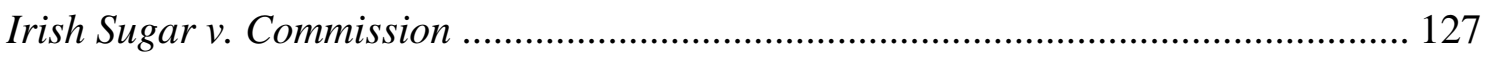

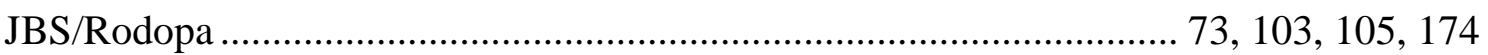

Kaiser vs. Ambev ............................................................. 150, 172, 173, 182

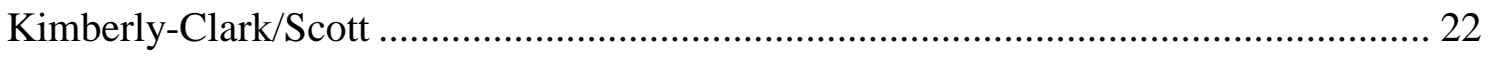

Koch Advogados Associados vs. Koch e Koch Advogados e Consultores ................... 48

Laboratório Biosintética Ltda v. Laboratório Sandoz S/A .......................................... 132

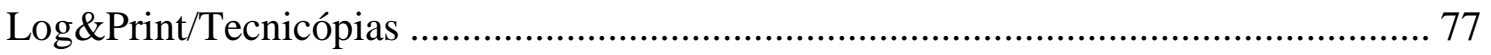

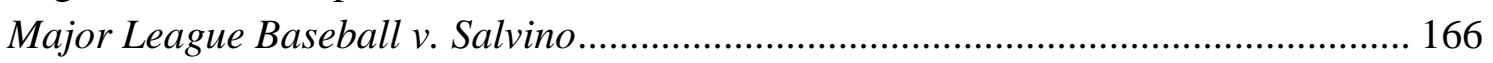

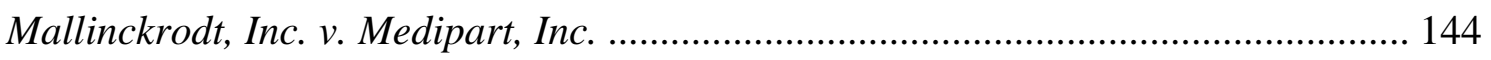

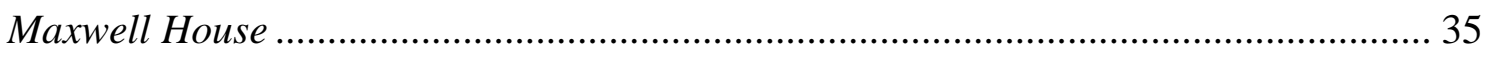

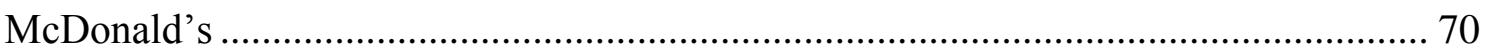




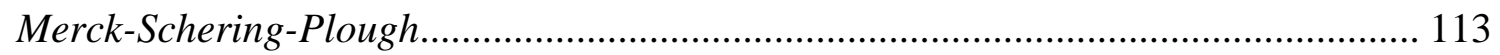

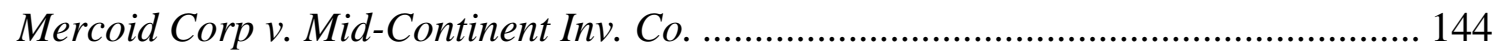

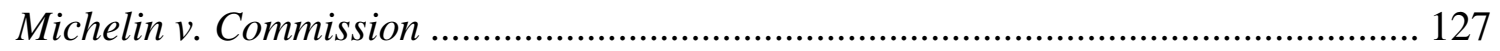

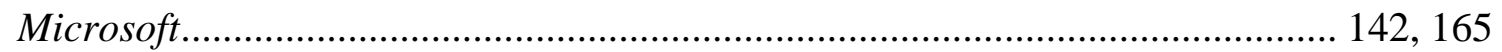

Microsoft v. Commission …...................................................................... 127, 165

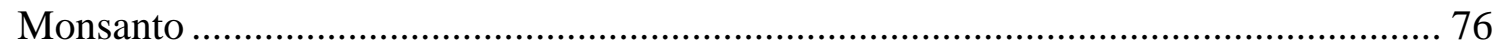

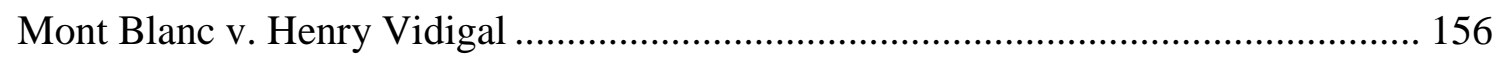

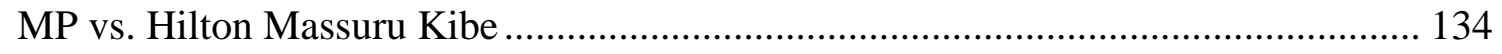

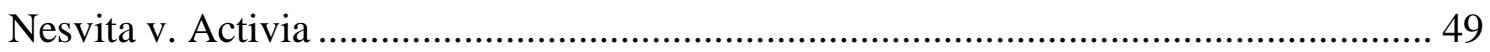

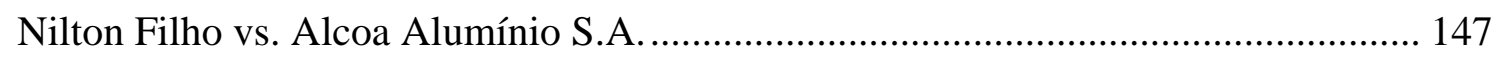

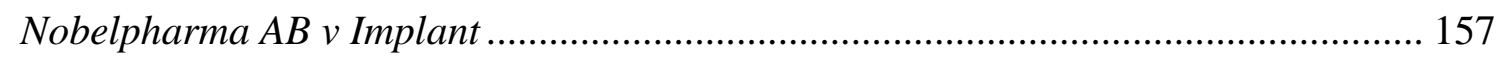

Orlando Cezar e outros v. União Federal ..................................................................... 153

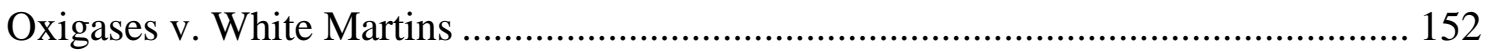

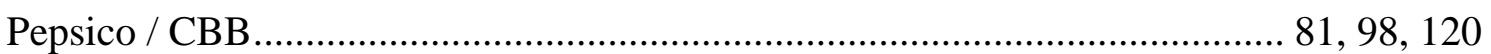

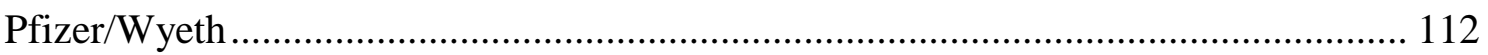

PGR v. Governador do Estado do Rio de Janeiro e ALERJ........................................... 57

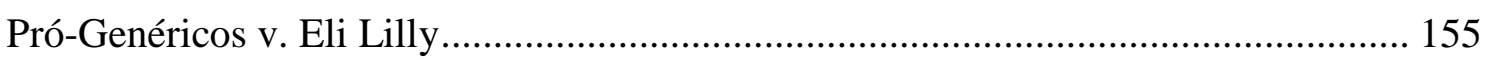

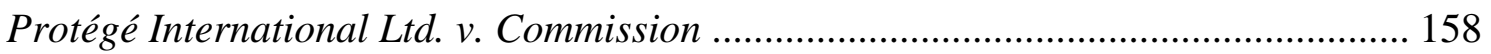

Qualitex Co. v. Jacobson Prods. Co. Inc................................................................... 25

Radio Telefis Eireann (RTE) and Independent Television Publications Ltd (ITP) $v$.

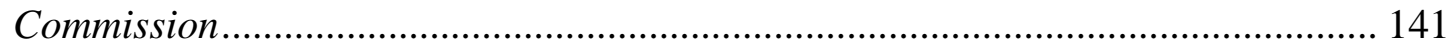

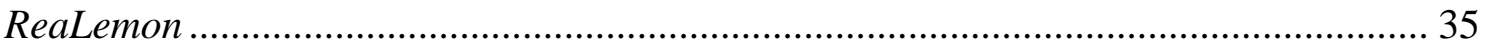

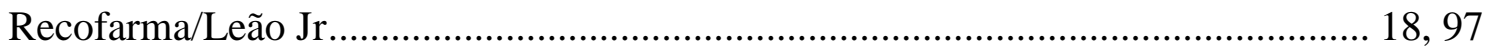

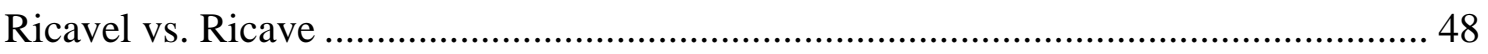

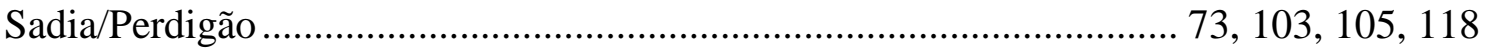

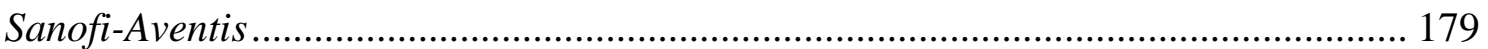

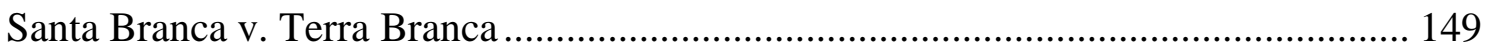

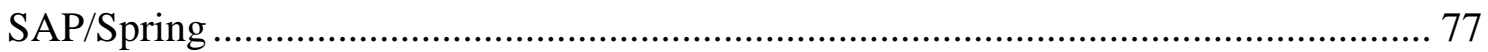

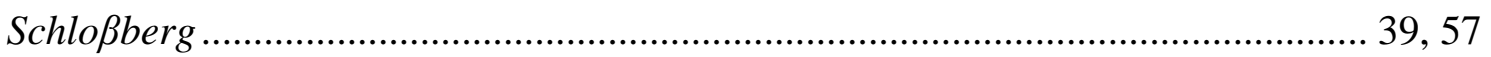

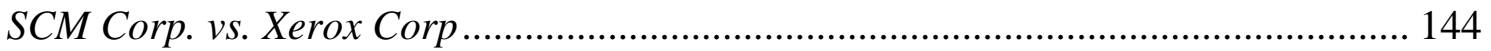

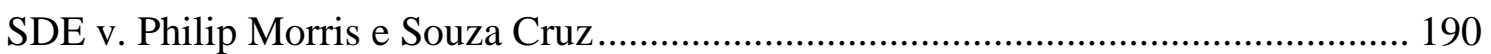

SDE v. Santos Brasil S/A - TECON Terminal de Contêineres e outros ....................... 131

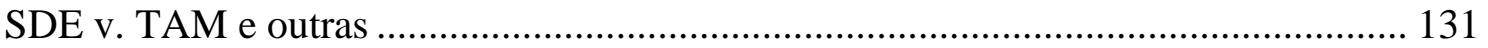

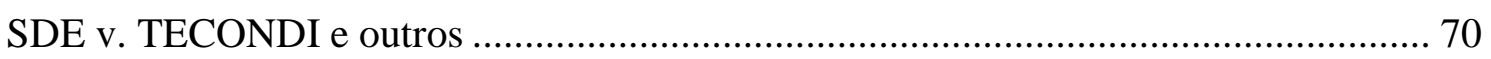

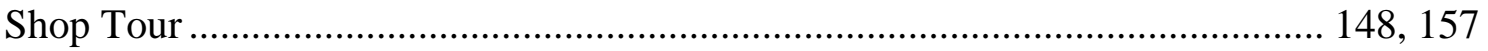

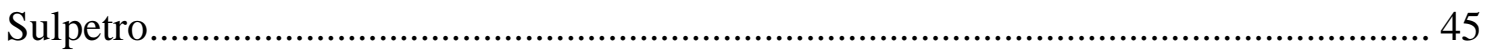

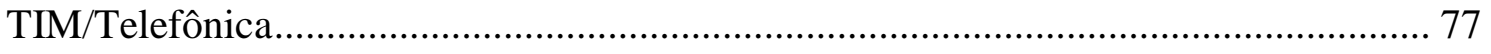

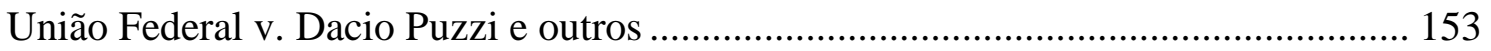

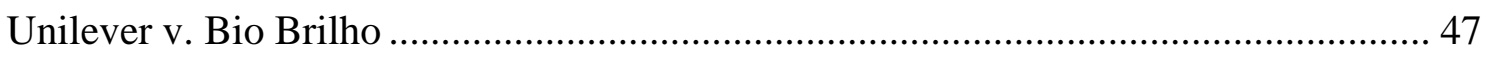

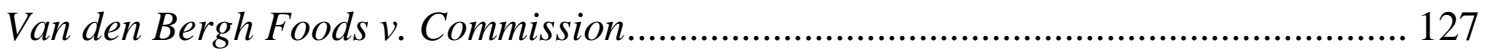

Vigor v. Kellog e Danone..................................................................... 149, 154, 186

Vinhos e Bebidas Caldas / Bebidas Cinzano ................................................................ 149

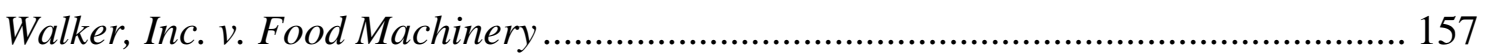

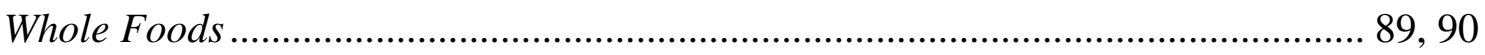


Zeloso v. Transall 